
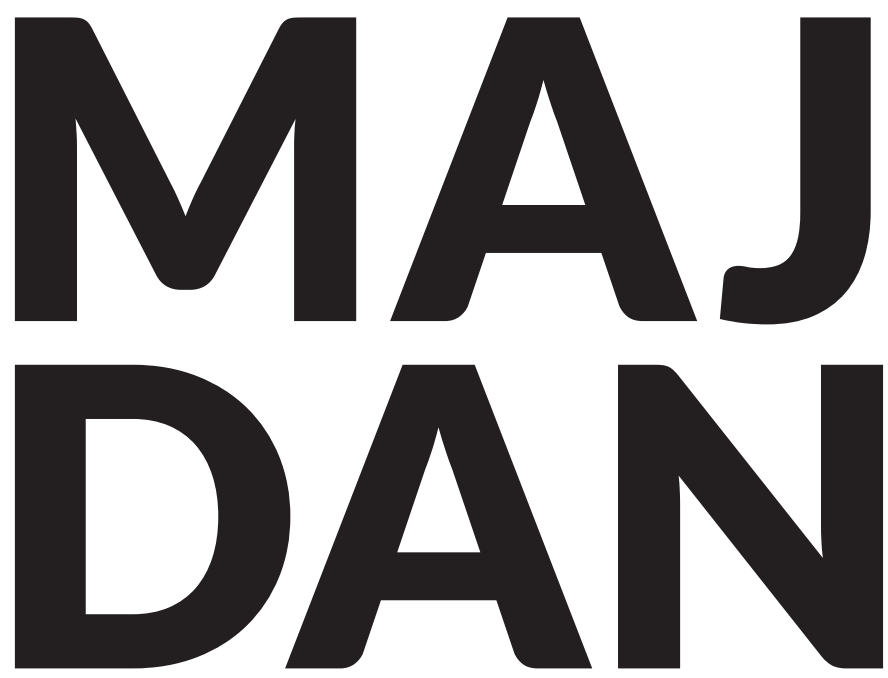

\title{
Drugie narodziny narodu
}




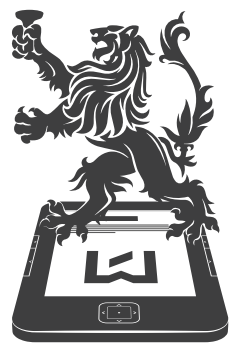

WYDAWNICTWO

UNIWERSYTETU

ŁOODZKIEGO 


\section{Rafał Kowalczyk}

Swietłana Grela-Krawczenko

Przemysław Waingertner
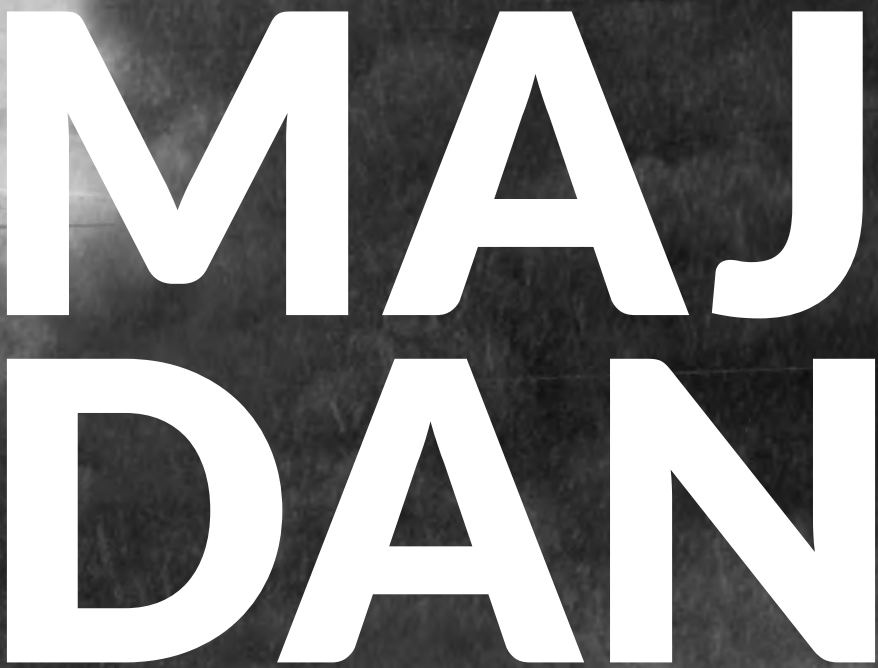

\section{Drugie narodziny narodu}

$7 \%$

ВН ПРЕКРАСНI!!!!

А ВАC АЮБАЮ!

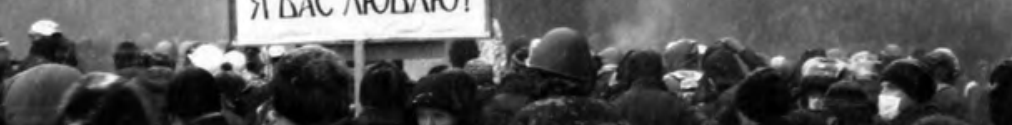

(1)

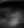
$\infty$

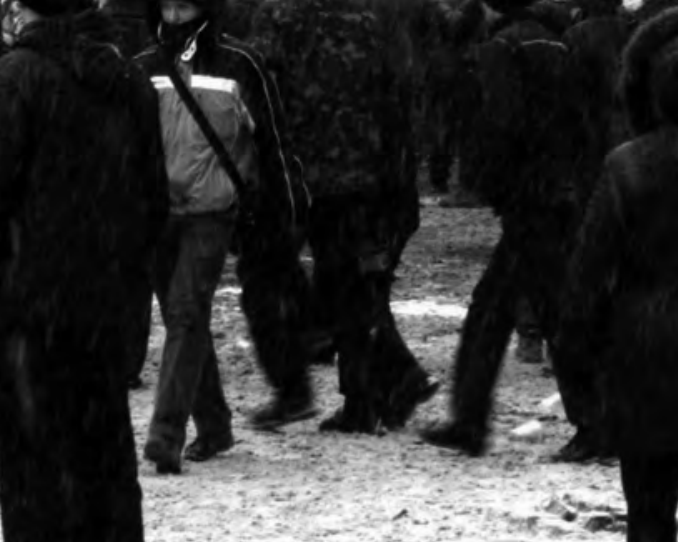

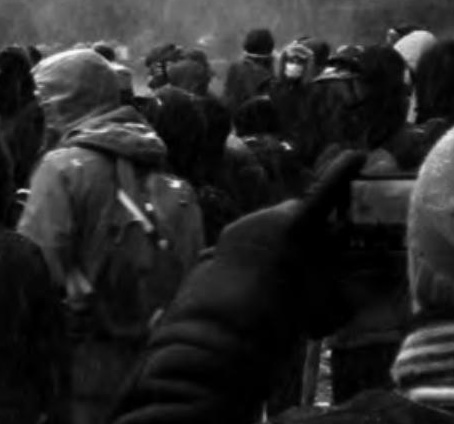


Rafał Kowalczyk - Uniwersytet Łódzki, Wydział Filozoficzno-Historyczny Katedra Historii Polski XIX w., 90-219 Łódź, ul. Kamińskiego 27a

Swietłana Grela-Krawczenko - Wschodnioeuropejski Narodowy Uniwersytet im. Łesi Ukrainki w Łucku

Przemysław Waingertner - Uniwersytet Łódzki, Wydział Filozoficzno-Historyczny Katedra Historii Polski Najnowszej, 90-219 Łódź, ul. Kamińskiego 27a

Autorzy zdjęć: Rafał Kowalczyk, Swietłana Grela-Krawczenko

\section{REDAKTOR INICJUJĄCY}

Urszula Dzieciątkowska

\section{RECENZENCI}

Grzegorz Hryciuk, Iwan Krupskyj

\section{REDAKTOR WYDAWNICTWA Ut}

Bogusław Pielat

SKŁAD I ŁAMANIE

Katarzyna Turkowska

\section{PROJEKT OKŁADKI}

Katarzyna Turkowska

(C) Copyright by Authors, Łódź 2015

(C) Copyright for this edition by Uniwersytet Łódzki, Łódź 2015

Wydane przez Wydawnictwo Uniwersytetu Łódzkiego

Wydanie I. W.07065.15.0.K

ISBN 978-83-7969-931-5

e-ISBN 978-83-7969-932-2

Wydawnictwo Uniwersytetu Łódzkiego

90-131 Łódź, ul. Lindleya 8 www.wydawnictwo.uni.lodz.pl

e-mail: ksiegarnia@uni.lodz.pl

tel. (42) 6655863 


\section{SPIS TRE śCI}

7 Wstęp

\section{Pod znakiem Tryzuba}

17 Rozdział I. Rusowie, Rusini, Kozacy, Ukraińcy...

39 Rozdział II. Podzieleni

63 Rozdział III. Od Białowieży do „Pomarańczowej Rewolucji”

83 Rozdział IV. Majdan. Przyczyny - wybuch - co dalej?

117 Mój Majdan - relacja Swietłany Krawczenko z płonących barykad Kijowa

145 Kilka słów o Lwowie czasu ukraińskiej rewolucji i o symbolu ukraińskiej wolności roku 2014 - kijowskim Majdanie (relacja Rafała Kowalczyka)

151 Bibliografia

\section{Euromajdan w Kijowie}

\section{Euromajdan w tucku}

294 Euromajdan we Lwowie 



\section{WSTĘP}

Autorzy tego wydawnictwa winni są Czytelnikowi już na początku pewne wyjaśnienie. Cała trójka - choć w swej codziennej działalności związanej z uprawianą profesją zajmuje się również (z wielką satysfakcją) popularyzowaniem wiedzy historycznej na łamach prasy, podczas odczytów i publicznych debat, $\mathrm{w}$ radiu i w telewizji - należy przede wszystkim do interdyscyplinarnego cechu zawodowych pracowników naukowych wyższych uczelni.

Swietłana Grela-Krawczenko jest profesorem na Wschodnioeuropejskim Narodowym Uniwersytecie im. Łesi Ukrainki w Łucku, na ukraińskim Wołyniu - autorką wielu publikacji, przede wszystkim z zakresu historii mediów, stosunków polsko-ukraińskich, filologii słowiańskiej i krajoznawstwa Wołynia. Ponadto pracuje jako dziennikarka. Rafał Kowalczyk pracuje na stanowisku profesora w Katedrze Historii Polski XIX wieku na Uniwersytecie Łódzkim (UŁ), koncentrując się w swych zajęciach dydaktycznych, badaniach i licznych publikacjach m.in. na epoce napoleońskiej, dziejach gospodarczych Polski i świata od czasów nowożytnych do współczesności oraz historii Ukrai- 
ny. Z kolei profesor Przemysław Waingertner jest pracownikiem Katedry Historii Polski Najnowszej UŁ, a jego zainteresowania badawcze i będące ich wynikiem książki i artykuły skupiają się tematycznie m.in. na polskim życiu i myśli politycznej oraz dziejach oręża polskiego w XX stuleciu, historii regionalnej łódzkiej „Ziemi Obiecanej”, a także historii Rosji.

Jednak autorzy publikacji byliby nieszczerzy zarówno wobec siebie, jak i Czytelnika, gdyby zadeklarowali, iż u podstaw idei przygotowania niniejszej książki legły pobudki czysto naukowe, badawcze i poznawcze. W istocie stanowiły one dla niej najważniejszą, lecz z pewnością nie jedyną motywację. Od początku towarzyszył im silny imperatyw polityczny i moralny.

Przedstawić po opracowaniu zebraną przez świadków, bogatą i niepublikowaną dotąd, dokumentację fotograficzną ilustrującą historyczne, dramatyczne wydarzenia na tzw. Majdanie, czyli kijowskim Placu Niepodległości (ale także w Łucku i we Lwowie - bliskich Polsce geograficznie, a Polakom również ze względu na historię, emocje i sentyment), przykuwające uwagę uczestników i obserwatorów przez trzy miesiące - od schyłku listopada 2013 r. do końca lutego 2014 r., wzbogacić ikonografię o obszerny wstęp, ukazujący w ogromnym skrócie nie tylko dzieje Ukraińców i Ukrainy, przybliżający je polskiemu zwłaszcza Czytelnikowi, ale próbujący zarazem objaśnić i scharakteryzować choćby pokrótce - przy świadomości ryzyka nieuchronnych uproszczeń i uogólnień - korzenie, historyczne okoliczności kształtowania się i współczesne uwarunkowania mentalności, charakteru narodowego i postaw politycznych Ukraińców, również wobec ich północno-zachodnich, polskich sąsiadów. Tak można przedstawić naukowe cele, jakie przyświecały autorom niniejszego wydawnictwa.

Jednakże w pracy nad książką towarzyszyło im również głębokie przekonanie, że poprzez rzetelne wykonanie tak spre- 
cyzowanych zadań dokumentacyjnych i badawczych osiągną także cel pozanaukowy, przyczyniając się - choćby i w bardzo skromnym, ograniczonym zakresie - do wzajemnego poznania i zrozumienia, w konsekwencji zaś do pojednania, budowy zaufania i wreszcie skierowanego w przyszłość porozumienia pomiędzy Polakami i Ukraińcami. I to pomimo niełatwej, dramatycznej, niekiedy krwawej i brzemiennej w tragedie, ale wszak obfitującej również w chwile wspólnej chwały politycznej i wojennej, polsko-ukraińskiej historii.

Autorzy książki głęboko wierzą w trafność znanej sentencji, głoszącej, że historia jest nauczycielką życia. Są przekonani zarazem (przyjmując zarzuty pesymistów i sceptyków, nie bez racji twierdzących z ironią, iż jeżeli historia kogokolwiek, kiedykolwiek i czegokolwiek nauczyła, to tylko tego, że nikogo, nigdy i niczego), że nawet jeśli nie „,jest”, a jedynie rzadko tylko „bywa”, nie zwalnia to cechowej braci naukowców od podejmowania - w poczuciu odpowiedzialności za losy oraz przyszłość rodaków i ojczyzny - starań, by te wyjątki zamieniać w regułę. Historia zaś Polski, Ukrainy i całego obszaru Europy Wschodniej wskazuje, że nie tylko suwerenność, bezpieczeństwo i możliwości rozwoju Rzeczypospolitej i Ukrainy (zarówno w sferze politycznej, jak i gospodarczej), ale także stabilność regionu, w którym Polacy i Ukraińcy należą do najliczniejszych narodów, a ich państwa do największych terytorialnie, o największym potencjale politycznym, ekonomicznym i militarnym, jest pochodną dobrych i bliskich relacji pomiędzy Warszawą i Kijowem. Relacji, które wsparte podmiotową, niepodległościową postawą państw nadbałtyckich i skandynawskich, a zarazem solidarną polityką w ramach transatlantyckiego porozumienia wojskowego i mechanizmów europejskiej integracji gospodarczej stanowić mogą filar ich bezpieczeństwa w obliczu współczesnych i przyszłych zagrożeń ze strony Rosji.

Autorzy pesymistycznie oceniają prognozy, przewidujące w przyszłości możliwość demokratyzacji i liberalizacji ustroju 
Rosji, którym miałaby towarzyszyć rezygnacja Kremla z imperialnej, rewizjonistycznej i agresywnej polityki zagranicznej. Podzielają natomiast opinię tych ekspertów w sprawach rosyjskich, którzy twierdzą, iż tak jak współczesna Rosja nie jest demokracją, lecz w istocie reżimem dyktatorskim, tak spójna z tym systemem i niezmienna od stuleci jest mentalność Rosjan - nie demokratyczna, liberalna i indywidualistyczna, ufundowana na wartościach zachodniej cywilizacji łacińsko-anglosaskiej, ale autorytarna, wspólnotowa, uznająca prymat argumentu siły nad siłą argumentu, wywodząca się z tradycji orientalnych, azjatyckich. Ze spójności tej wynika m.in. wywołujący konfuzję politycznych komentatorów pozorny paradoks masowego poparcia, udzielanego przez „ciemiężonych” Rosjan „ciemiężącemu” ich „tyranowi”. Rosjanie akceptują bowiem władzę silną - nawet brutalną i bezwzględną - i skuteczną, legitymizującą się sukcesami, wykazującą wobec rządzonych postawę patrona i opiekuna, ostatecznej instancji odwoławczej.

Taki model relacji pomiędzy rządzącymi i rządzonymi uwarunkowało historycznie panowanie najeźdźców ze Skandynawii - twórców państwa ruskiego, okrutne rządy Mongołów, „upaństwowione” prawosławie wspierające idee omnipotentnego władcy i absolutnego poddaństwa ludu, samodzierżawie „Cara-Ojca Narodu”, wreszcie totalitarny komunizm. Taki model argumentu siły rosyjscy przywódcy przenoszą do polityki zagranicznej (przykłady współczesne to agresja na Ukrainę, a wcześniej na Gruzję oraz próba siłowej odbudowy wpływów w Europie Wschodniej). Czynią to z jednej strony wierni metodom, które sprawdzają się w Rosji (a i wobec innych państw, bezradnych wobec dyktatora wspieranego przez rządzonych), z drugiej - dążąc do wzmocnienia swej pozycji w kraju (którego obywatele rekompensują sobie materialną mizerię świadomością bycia mieszkańcami mocarstwa) poprzez ogłaszanie kolejnych międzynarodowych triumfów. 
Ostatnia z motywacji ma charakter moralny i jest chyba jasna dla wszystkich, którzy u schyłku roku 2013 i na początku 2014 mieli okazję śledzić w przekazach telewizyjnych, radiowych i prasowych dramatyczne wydarzenia z Majdanu. Konfrontacja patriotyzmu, poświęcenia, odwagi, obywatelskiej postawy, imperatywu obrony godności człowieka i determinacji w walce o lepszą przyszłość kraju, wspólnoty społecznej i narodowej z brutalną siłą i dyktaturą, odartą choćby z cienia społecznej akceptacji; $z$ bezwzględ nym dążeniem do narzucenia dumnemu narodowi zwierzchnictwa ościennego mocarstwa - nie mogła pozostawić, zdaniem autorów, miejsca na obojętność czy relatywizowanie ocen w imię subtelności politycznych bądź światopoglądowych. Zwłaszcza chyba wśród Polaków, dobrze pamiętających represje stanu wojennego, wprowadzonego w imię obrony interesu rządzącego schyłkowym PRL-em partyjno-wojskowego reżimu i dominacji Związku Sowieckiego nad Polską. Analogia z działaniami ekipy Wiktora Janukowycza, zmierzającego do utrzymania rosyjskiej hegemonii nad Ukrainą, jest tu uderzająca.

Książka ma budowę dwudzielną. Otwiera ją wprowadzenie do dziejów Ukrainy i Ukraińców oraz samego Majdanu, w którym autorzy starali się zaakcentować te wydarzenia tudzież procesy $z$ historii naszych południowo-wschodnich sąsiadów, które byłyby użyteczne w objaśnianiu ukraińskiej mentalności i tłumaczeniu społeczno-politycznego fenomenu Majdanu. Zostało ono skonstruowane z sześciu części - czterech zasadniczych rozdziałów i dwóch świadectw-wspomnień.

Pierwszy z rozdziałów to zarys dziejów Ukrainy i Ukraińców od okresu, który określić można jako prehistorię państwa i narodu znad Dniepru, aż po dramatyczny dla naszych południowo-wschodnich sąsiadów finał I wojny światowej i wojen o granice w Europie Wschodniej, oznaczający włączenie Ukrainy jako „socjalistycznej republiki” w skład totalitarnego pań- 
stwa sowieckiego. Drugi prezentuje losy podzielonego granicami państwowymi narodu ukraińskiego w latach międzywojnia, II wojny światowej i po jej zakończeniu, aż do historycznego momentu upadku komunizmu, rozpadu Związku Sowieckiego i ogłoszenia niepodległości Ukrainy. Kolejny - niezwykle burzliwy nad Dnieprem schyłek XX stulecia i pierwsze lata XXI w., których zamknięciem wydawała się „Pomarańczowa Rewolucja” z przełomu 2004/2005 r. Rozdział czwarty ukazuje lata 2005-2014, w dziejach Ukrainy, znamienne próbami uformowania rządów prozachodniej „pomarańczowej” koalicji, jej rozpadem i przejęciem władzy przez obóz dążący do wprowadzenia rządów autorytarnych, opartych na poparciu i dominacji Rosji oraz krwawymi wydarzeniami na kijowskim Majdanie na przełomie lat 2013/2014. Do wspomnianych rozdziałów dołączone zostały dwa osobiste, źródłowe świadectwa Swietłany Greli-Krawczenko i Rafała Kowalczyka z dramatycznych wydarzeń na Ukrainie (w Kijowie i we Lwowie) w latach 2013-2014.

Na drugą część książki składa się kilkaset zdjęć, ilustrujących przebieg wydarzeń na Placu Niepodległości w Kijowie na przełomie lat 2013 i 2014 oraz towarzyszących im równolegle wystąpień we Lwowie. Autorami fotografii, ilustrujących historię kijowskiego Majdanu oraz lwowskich i wołyńskich wydarzeń są Swietłana Grela-Krawczenko i Rafał Kowalczyk. Zostały one opracowane wspólnie przez trójkę autorów.

Książka ta dedykowana jest znanym i bezimiennym, żywym i poległym bohaterom Majdanu oraz obrońcom suwerenności i integralności terytorialnej ukraińskiego państwa w obliczu rosyjskiej agresji.

Autorzy dziękują za uwagę, poświęconą niniejszemu wydawnictwu, recenzentom: polskiemu - prof. nadzw. dr. hab. Grzegorzowi Hryciukowi z Instytutu Historycznego Uniwersytetu Wrocławskiego i ukraińskiemu - profesorowi Iwanowi 
Wasilowiczowi Krupskiemu z Lwowskiego Narodowego Uniwersytetu. Gorące wyrazy wdzięczności należą się również pracownikom Wydawnictwa Uniwersytetu Łódzkiego (WUŁ), zaangażowanym w przygotowanie książki do druku i jej wydanie oraz - za wielką życzliwość i wsparcie - Dyrektorowi WUŁ, Pani Ewie Bluszcz. 


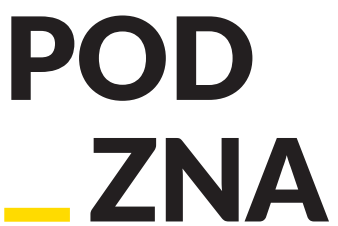

KIEM

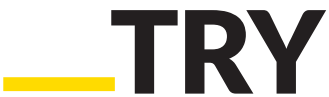

ZUBA 



\section{- ROZ DZIAt -I}

\section{Rusowie, Rusini, Kozacy, Ukraińcy...}

Zachodnioeuropejscy i amerykańscy historycy badający dzieje Rosji, sowietolodzy i publicyści z przekąsem zwracali w przeszłości uwagę, że w rosyjskich i sowieckich podręcznikach historii narracja, dotycząca dziejów państwa rosyjskiego, a później i Związku Sowieckiego (ZSRS) rozpoczynała się nieraz od... starożytnego państwa Urartu. Zabieg ten, nieco zaskakujący dla zachodnich profesjonalnych dziejopisów i amatorów-pasjonatów domeny Klio, wyjaśniany bywał zarówno nazbyt encyklopedycznym i drobiazgowym podejściem do zagadnienia korzeni Rosji i ZSRS, które mieli prezentować rosyjscy i sowieccy historycy, jak też - znacznie częściej i zapewne o wiele trafniej - znamiennym dążeniem (zgodnym zresztą z oczekiwaniem władz) do dowartościowania Rosjan i obywateli „Ojczyzny Światowego Proletariatu” przez wykazanie starożytnych tradycji instytucji państwa na zamieszkanych przez nich obszarach. Jeśli w istocie ta swoista interpretacja "pradziejów” Rosji i Związku Sowieckiego miała mieć własności terapeutyczne, lecząc z kompleksu cywilizacyjnego zapóźnienia i kulturowego wyobcowania oraz występującego u Rosjan poczucia 
powszechnego, krzywdzącego niezrozumienia ich mocarstwowych aspiracji zarówno przez sąsiadów, jak i rywali do miana europejskiego, a z czasem i światowego hegemona, to przyznać trzeba, że współcześnie chętnie przechodzą oni do porządku dziennego nad tym curiosum i skrzętnie je przemilczają, zarzucając podobny grzech historycznej mania grandiosa Ukraińcom i drwiąc z poszukiwania przez południowo-zachodnich sąsiadów antenatów ich państwa w epoce antycznej, a przede wszystkim w strukturach państwowości Rusi Kijowskiej (której jedynym i niekwestionowanym spadkobiercą i kontynuatorem ma być wszak, zdaniem Rosjan, ich własne, odrestaurowane, eurazjatyckie imperium).

Podejmowane przez część ukraińskich dziejopisów i nieprofesjonalnych amatorów ojczystej historii znad Dniepru próby poszukiwania jej korzeni w antyku można wyrozumiale tłumaczyć naturalną ambicją narodu od niedawna cieszącego się niepodległą państwowością do „odkrywania” jej mniej lub bardziej uzasadnionych antecedencji lub „warsztatową” spuścizną po historiografii rosyjskiej i sowieckiej (wszak Ukraina przez trzy stulecia stanowiła część carskiego, a później bolszewickiego imperium). Zarazem jednak zjawisko to jest znamienne i ważne, jeśli potraktować je jako jeden z objawów współczesnych ukraińskich dążeń do wypracowania modelu własnej historycznej - narodowej i państwowej - tożsamości; swoistych peregrynacji w czasie w poszukiwaniu integrujących symboli, haseł i mitów założycielskich ukraińskiej wspólnoty narodowej oraz instytucji państwa; wysiłków podejmowanych w celu ustalenia galerii narodowych bohaterów i idoli politycznych - ojców-założycieli narodu i państwa, stanowiących wzorzec, a zarazem punkt odniesienia w działalności publicznej, wolnych od kontrowersji na tyle, aby stali się ogólnonarodowymi, powszechnie uznawanymi personifikacjami „ukraińskości” i osobowymi egzemplifikacjami patriotyzmu. 
Wspomniane poszukiwania historycznych korzeni narodu i państwa, podejmowanie prób samookreślenia narodowej tożsamości, formułowanie opartych na nich politycznych haseł, identyfikowanie się z określoną tradycją, symbolami i postaciami bohaterów etnicznej ukraińskiej wspólnoty były charakterystycznym i naturalnym zjawiskiem, towarzyszącym wydarzeniom na kijowskim Majdanie. Budziło ono zainteresowanie, a niekiedy i kontrowersje wśród samych uczestników protestu; prowokowało komentarze przychylnych mu i krytycznych obserwatorów na Ukrainie i za jej granicami; wreszcie inspirowało interesujące analizy politologów i badaczy dziejów naszego wschodniego sąsiada, w których - niezależnie od dokonywanych przez specjalistów ocen symboli, haseł i narodowych idoli - wspólnym elementem było podkreślanie trudności przed jakimi stoi stosunkowo młody naród, usiłujący ustalić wspólną wykładnię własnych, dramatycznych i niełatwych przecież dziejów.

Warto zatem choćby pokrótce przedstawić historię ( $\mathrm{i}$ „prehistorię") Ukraińców - zarówno po to, by poznać drogę, która doprowadziła ich do ukonstytuowania niepodległego państwa u schyłku XX stulecia i jego „odzyskania” (jak ujmowali to sami uczestnicy Majdanu) ćwierć wieku później, jak też, by zrozumieć i ocenić odniesienia "Majdanowców” do dziejów własnego narodu i dokonywane przez nich wybory haseł, faktów i bohaterów, które uznali za konstytuujące ich współczesną tożsamość.

Jak z dumą podkreślają sami Ukraińcy, na ziemiach znajdujących się obecnie w granicach ich państwa już w okresie neolitu wyodrębniły się pierwsze kultury, określane przez archeologów mianem dniepro-donieckiej, bugo-dniestrzańskiej i Kemi-Oba, zdominowane następnie przez kulturę tyraspolską, a później - plemiona kultury tzw. ceramiki sznurowej (które były przypuszczalnie przodkami Germanów, Słowian i Bałtów), trzcinieckiej i konarowskiej (w XV-XI w. p.n.e.), wreszcie 
biełogrudowskiej (XI-IX w. p.n.e.), określanej przez wielu badaczy mianem poprzedniczki kultury wschodniosłowiańskiej. Teren Ukrainy był również prawdopodobnie ojczyzną języka praindoeuropejskiego.

Do VII w. p.n.e. najstarszym historycznym plemieniem, którego obecność została odnotowana na północ od Morza Czarnego byli Kimerowie. Zasiedlali te obszary również Scytowie (do IV w. p.n.e.) i Sarmaci (do III w. n.e.). Tym ostatnim swą nazwę zawdzięcza ukraiński Don (słowo „don” w języku sarmackim oznaczało rzekę). Z kolei już w VIII-VI w. p.n.e. na Krymie oraz u ujścia Bohu i Donu do Morza Czarnego swe kolonie - Chersonises, Eupatorię, Fanagorię, Gorgippę (obecnie Anapa), Nikonij, Olbię, Pantikapajon (dziś Kercz), Tanais, Teodozję, Tyras - zakładali Grecy. Były to nadbrzeżne miasta zbudowane na wzór greckich polis, prowadzące handel wyrobami rzemiosła w zamian za zboże, bydło, miód, wosk, skóry i ryby. Dały one z czasem początek najstarszemu znanemu z historii państwu powstałemu na terenach dzisiejszej Ukrainy - tzw. Królestwu Bosporańskiemu, które zawdzięczało swoją nazwę Bosforowi Kimmeryjskiemu, czyli dzisiejszej Cieśninie Kerczeńskiej, a które przeszło później pod zwierzchnictwo imperium rzymskiego. W epoce kryzysu imperium i upadku Cesarstwa Rzymskiego na zachodzie Europy, w III-IV w., południowe obszary współczesnej Ukrainy znalazły się we władaniu germańskich Gotów, którzy podbili miejscowe plemiona. Tereny te były później również świadkami wędrówek na zachód Hunów, Awarów, Protobułgarów i Madziarów. Same z kolei stawały się nową ojczyzną dla zasiedlających je Chazarów, Pieczyngów i Połowców.

W następnych stuleciach na terenach Ukrainy zaczęły pojawiać się i kształtować wspólnoty słowiańskie, które miały stać się twórcami kolejnych kultur, dominujących na północ od Morza Czarnego - kijowskiej i pieńkowskiej (zdaniem części historyków również wcześniejszych - zarubinieckiej, miłogradzkiej 
i czernoleskiej). We wczesnym średniowieczu dorzecze Dniepru było także przedmiotem zainteresowania szwedzkich Waregów, którzy rozciągnęli swoje wpływy na brzegi dnieprowych dopływów, wznosząc nad nimi ufortyfikowane osady i grody. Były one nie tylko ośrodkami, ułatwiającymi sprawowanie kontroli nad miejscową ludnością, ale również punktami umożliwiającymi efektywne ściąganie z niej daniny. Składały się na nią nie tylko wosk czy futra, ale także kontyngenty niewolników - sprzedawane później przez wojowniczych, ale posiadających jednocześnie zmysł kupiecki Waregów w Cesarstwie Bizantyńskim i w krainach opanowanych przez Arabów.

W latach sześćdziesiątych IX w. jeden z wareskich wodzów, Ruryk, zjednoczył pod swym panowaniem Waregów, Słowian Ilmeńskich i Krywiczy nad górnym i środkowym Dnieprem, zapoczątkowując dzieje najstarszego wschodniosłowiańskiego państwa i stając się założycielem rządzącej nim odtąd przez siedem stuleci dynastii Rurykowiczów. Zdominowanie przez skandynawskich najeźdźców miejscowej ludności sprawiło też najprawdopodobniej, że od ugrofińskiej nazwy jednego z wareskich plemion Routsi (Rus), czyli „wojownik”, „mieszkaniec wybrzeża", lub też od nordyckich słów ropsmenn (ropskalar), oznaczających sternika, zaczęto państwo to coraz częściej i powszechniej nazywać Rusią. Ponieważ jego stolicą był Nowogród Wielki, określano je także mianem Rusi Nowogrodzkiej. Obok Nowogrodu głównymi grodami państwa Ruryka były: Połock, Rostów i Biełoziersk. Władali nimi podlegli panu na Nowogrodzie możni, sprawując równocześnie rządy w przyznanych im przez niego dzielnicach.

Z czasem w ślady Ruryka zdecydowali się pójść dwaj inni warescy wodzowie, Askold i Dir, którzy na czele zbrojnej drużyny w poszukiwaniu własnej domeny oddzielili się od władcy Rusi i w dorzeczu dolnego Dniepru zawładnęli plemiennym państwem Polan ze stolicą w Kijowie. Jednak w końcu IX w. mściwa 
ręka Rusi dosięgła niepokornych Waregów. Następca Ruryka, Oleg Mądry, najpierw przyłączył do Rusi Gniezdowo (obecnie Smoleńsk), wraz z otaczającymi je terenami, a następnie ruszył na południe i podbił młode państwo Askolda i Dira, przenosząc swą stolicę do zdobytego Kijowa, wzbogaconego dzięki zyskownemu handlowi z pobliskim Bizancjum. Ambitni rywale jego ojca i niedawni pogromcy Polan ponieśli najprawdopodobniej śmierć. Zdobycie państwa Askolda i Dira przez Olega dało początek nowemu państwu - Rusi Kijowskiej, która w wyniku dalszej ekspansji objęła swymi granicami ziemie należące do dzisiejszej Ukrainy, Mołdawii, Rosji, Białorusi i Polski.

Z rozszerzeniem się władzy Rurykowiczów na południowe dorzecze Dniepru związane są kolejne teorie dotyczące pochodzenia nazwy Ruś. Państwo utworzone niegdyś przez Ruryka miałoby je zawdzięczać tym razem greckiej nazwie rzeki Wołgi - Rhos (lub łacińskiej - Rha), zapożyczonej przez ludność zamieszkującą wówczas na południu dzisiejszej Ukrainy; nazwie rzeki Roś, przepływającej w okolicach Kijowa; ewentualnie miałaby pochodzić od nazwy starożytnego sarmackiego plemienia Roksolanów, którzy niegdyś zamieszkiwali dorzecze południowego Dniepru. Warto też dodać, że niektórzy ukraińscy i rosyjscy historycy upatrują - zapewne nieco koniunkturalnie i w pogoni za łatwą, a zarazem błyskotliwą analogią - w średniowiecznym starciu Rusi Nowogrodzkiej i państwa Askolda i Dira profetycznego, symbolicznego początku rosyjskiej ekspansji na Ukrainę i współczesnego ukraińsko-rosyjskiego konfliktu.

Dalszą historię Rusi Kijowskiej w X w. wyznaczały kolejne kampanie tego drapieżnego państwa przeciwko Konstantynopolowi, które stały się dla potomków Ruryka sposobem na skłonienie słabnącego Cesarstwa do zawierania z nimi korzystnych dla Kijowa traktatów handlowych i składania Rusi danin-okupów, mających powstrzymać najazdy. Równocześ- 
nie, dzięki zwycięskim wyprawom Światosława I w drugiej połowie X w., podejmowanym przeciwko Chazarom, Pieczyngom i Bułgarom, Ruś Kijowska rozszerzyła swe granice, stając się dla sąsiadów zarówno pożądanym sojusznikiem, jak i potencjalnie niezwykle groźnym wrogiem.

W tej sytuacji nie może dziwić, iż syn Światosława, Włodzimierz I Wielki, zyskał pozycję władcy godnego ręki bizantyńskiej księżniczki Anny, siostry cesarza Bazylego II Bułgarobójcy, po czym w pamiętnym 988 r. przeprowadził z pomocą duchownych z Konstantynopola chrzest Rusi (tym razem okazał się on trwały - trzeba przypomnieć, iż już wcześniej, w połowie IX, a następnie X stulecia Rusowie przyjmowali chrześcijaństwo, powracając jednak rychło do pogańskiej wiary przodków). W wyniku chrystianizacji Rusi, Kijów stał się siedzibą kolejnego na Wschodzie metropolity i centrum religijnym ziem ruskich. W konsekwencji - po Schizmie Wschodniej z 1054 r. - ziemie ruskie znalazły się w strefie wpływu Kościoła prawosławnego, rywalizującego o miano prawdziwie chrześcijańskiego z zachodnim Kościołem katolickim.

Ważną cezurą w dziejach Rusi Kijowskiej okazało się panowanie Jarosława Mądrego (1019-1054), który z jednej strony przeszedł do historii jako budowniczy miast, mecenas nowej, chrześcijańskiej kultury oraz inicjator organizowanych z rozmachem wypraw wojennych docierających na polskie Mazowsze, Litwę, a nawet do dalekich siedzib Estów (obecna Estonia), z drugiej - jako władca, który podzielił państwo pomiędzy synów, usiłując zarazem bezskutecznie zabezpieczyć jedność Rusi przez wprowadzenie zasady senioratu (zwierzchnictwa najstarszego z rodu nad młodszymi przedstawicielami dynastii).

Podział państwa na dzielnice okazał się trwały. Na miejscu dawnej Rusi Kijowskiej powstały rywalizujące ze sobą nowe państwa: republika nowogrodzka i księstwa - połockie, rostowsko-suzdalskie, riazańskie, smoleńskie, turowskie, kijowskie, ha- 
lickie, wołyńskie, czernichowskie oraz perejasławskie, podlegające dalszemu rozdrobnieniu. Nadal jednak to władanie Kijowem zapewniało wyższą pozycję w książęcej hierarchii i tytuł Wielkiego Księcia. W 1169 r. przypadł on ówczesnemu zdobywcy Kijowa, księciu włodzimiersko-suzdalskiemu Andrzejowi I, który jednak pozostawił rolę stolicy swego państwa Włodzimierzowi nad Klaźmą, poprzestając na obsadzaniu na stolcu kijowskim uległych sobie książąt. Z tego wczesnego okresu istnienia Rusi Kijowskiej pochodzą też pierwsze zabytki staroruskiej literatury - zbiór hagiograficznych opowieści pt. Mineje Czytane, Słowo o prawie i łasce autorstwa metropolity kijowskiego Hilariona (z XI w.) oraz Powieść minionych lat Nestora i Pouczenie Włodzimierza Monomacha (z XII w.).

W XIII i XIV w. przypieczętowany został upadek politycznego znaczenia podlegających podziałom i słabnących księstw ruskich. Na zachodzie większość z nich - m.in. księstwo kijowskie, wołyńskie, czernichowskie, perejasławskie, smoleńskie i połockie - znalazła się w granicach coraz potężniejszej Litwy, która rozciągnęła dzięki temu swe granice od Bałtyku do Morza Czarnego. Natomiast Ruś Halicko-Włodzimierska (tzw. Ruś Czerwona), z centralnymi grodami Lwowem i Przemyślem, stała się przedmiotem rywalizacji pomiędzy Królestwem Polskim i Węgrami, zakończonej ostatecznie jej wcieleniem do państwa polskiego w końcu XIV stulecia.

Z kolei na wschodzie ziemie ruskie zostały podbite lub uzależnione przez Mongołów po klęsce wojsk ruskich w bitwie nad Kałką w 1223 r. Najeźdźcy nie wcielili ich jednak do swego państwa, poprzestając na pobieraniu z nich daniny i zatwierdzaniu kolejnych książąt, mających odgrywać rolę zwierzchników pozostałych wschodnioruskich władców, a zarazem gwarantów ich uległości wobec Mongołów. Najsłynniejszym spośród nich miał okazać się Aleksander Newski, który godząc się z tatarskim jarzmem na wschodzie, pokonał równocześnie w latach 1240-1242 
wojska szwedzkie i Zakonu Kawalerów Mieczowych, zagrażające księstwom ruskim z zachodu. Równocześnie Mongołowie osiedlili się na północnych wybrzeżach Morza Czarnego i na Krymie, gdzie z czasem utworzony został tzw. Chanat Krymski.

Jak podkreśla (być może nieco upraszczając zagadnienie) część dziejopisów, wspomniane dwieście lat miało istotny czy nawet wręcz przełomowy wpływ na rozejście się historycznych dróg politycznego, społecznego-gospodarczego i kulturowego rozwoju ziem ruskich, które przez włączenie w granice Królestwa Polskiego bądź Litwy - złączonej z nim unią personalną (od 1385 r.) i podlegającej jego wpływom cywilizacyjnym - lub też zhołdowanie przez Mongołów, miały stać się domenami dwóch odmiennych ruskich cywilizacji: łacińskiej (europejskiej) i orientalnej (azjatyckiej), a przez to kolebkami trzech państwowości: hołdujących zasadom pierwszej cywilizacji - państwowości ukraińskiej i białoruskiej oraz drugiej - rosyjskiej.

W 1569 r. kijowszczyzna, bracławszczyzna, czernichowszczyzna i ziemie wołyńskie zostały na mocy nowej polsko-litewskiej unii realnej, zawartej w Lublinie i dającej początek Rzeczypospolitej Obojga Narodów - federacyjnemu państwu demokracji szlacheckiej - oderwane od Litwy i dołączone bezpośrednio do Królestwa Polskiego, zwanego w ramach przebudowanej unii Koroną. W 1596 r. stały się też one kolebką nowego Kościoła unickiego (greckokatolickiego), kiedy to na synodzie w Brześciu ruscy biskupi prawosławni, zachowując tradycyjną liturgię i ceremoniał swego wyznania, zdecydowali się uznać autorytet i zwierzchnictwo katolickiego papieża.

Nowe nabytki terytorialne Korony, leżące na jej południowo-wschodnim skraju, „u krańca” państwa, z tego też powodu określane coraz częściej wspólnym pojęciem „Ukrainy”, stały się w XVI-XVII w. obszarem, na którym równolegle zachodziło kilka procesów niezwykle istotnych zarówno dla przyszłości politycznej zamieszkujących je Rusinów, jak i ówczesnego 
polsko-litewskiego imperium, sięgającego od Bałtyku i Zatoki Fińskiej po Morze Czarne i od Poznania po Smoleńsk. Należały do nich: polonizowanie się i konwersja na katolicyzm dotychczasowych polityczno-społecznych elit ruskich (rusińskich); wykształcanie się wolnej, a zarazem niepokornej i wojowniczej, etniczno-społeczno-religijnej wspólnoty kozackiej, przejmującej rolę nowej, miejscowej elity; podejmowane w Rzeczypospolitej racjonalne (włączanie Kozaków jako wolnych ludzi w poczet wojsk koronnych) i nieracjonalne (próby narzucania przez szlachtę Kozakom, jako „chłopom”, osobistego poddaństwa i obowiązku odrabiania pańszczyzny) działania, zmierzające do zneutralizowania problemu kozackiego; wreszcie będące wynikiem tych ostatnich powstania kozackie przeciwko „kresowym panom”, czyli „Lachom” (Polakom).

Największe z nich, wzniecone w 1648 r. przez zajmującego poczesne miejsce w galerii ukraińskich bohaterów narodowych Bohdana Chmielnickiego, zapoczątkowane wielkimi triumfami militarnymi Kozaków, zakończyło się jednak lawiną nieszczęść, które w drugiej połowie XVII w. spadły na Rzeczpospolitą i Ukrainę - od krwawej i okrutnej wojny domowej, skutkującej spustoszeniem ziem ruskich, rozpaleniem polsko-ruskiego (ukraińskiego) antagonizmu i trwałym osłabieniem polsko-litewskiej federacji, po poddanie przez Chmielnickiego Ukrainy pod protekcję Rosji na mocy ugody w Perejasławiu (1654 r.), będącego jej wynikiem rosyjskiego najazdu na Rzeczpospolitą, wreszcie - podziału Ukrainy na część polską (na zachód od Dniepru) i rosyjską (na wschód od Dniepru), dokonanego w $1667 \mathrm{r}$. na mocy rozejmu andruszowskiego, a potwierdzonego w $1686 \mathrm{r}$. traktatem pokojowym.

Nieprzypadkowo trzydziestoletni okres po śmierci Bohdana Chmielnickiego (1657-1687) określany jest w dziejach Ukrainy terminem „ruina”. Po nieudanej próbie „zawrócenia koła historii” i przekształcenia Rzeczypospolitej Obojga Narodów 
w Rzeczpospolitą Trojga Narodów - którą mogła zapoczątkować niezrealizowana polsko-kozacka umowa w Hadziaczu w 1658 r. - nastąpił czas wojny domowej i kryzysu politycznego, tzw. Hetmańszczyzny, ustanowionej przez zmarłego pogromcę "Lachów”. Wywołały je z jednej strony dążenie kozackiej starszyzny do zdobycia i utrzymania władzy, z drugiej - apetyty tureckiego imperium osmańskiego, Szwecji, Rzeczypospolitej i Carstwa Rosyjskiego do przejęcia pełnej kontroli nad terytorium ukraińskim.

Apogeum swego rozwoju osiągnęła Hetmańszczyzna za rządów hetmana Iwana Mazepy (1687-1708), który utrzymywał stosunki handlowe z szeregiem krajów europejskich. Ustały wówczas bunty i wojny. Rozwijało się rolnictwo dzięki pracy ukraińskich chłopów, wolnych od pańszczyzny. Gospodarczemu ożywieniu sprzyjał również system podatkowy, zaprowadzony przez Mazepę. Marzeniem jego samego było zjednoczenie Ukrainy Prawobrzeżnej i Lewobrzeżnej w jednolite państwo, łączące tradycyjny kozacki ustrój z modelem nowoczesnego, europejskiego zarządzania i efektywną gospodarką. Jednak cieniem na pomyślności ówczesnego ukraińskiego państwa kładła się polityka jego „protektora”, Moskwy, który traktował je jako wasala, żądając kozackiego rekruta do armii rosyjskiej i pieniędzy na modernizację państwa Romanowów. Ta rosyjska polityka dominacji spowodowała zerwanie przez Mazepę nierównoprawnego sojuszu z Rosją i wejście w początkach XVIII stulecia w alians ze Szwecją. Zakończył się on jednak tragicznie dla Ukraińców - po klęsce szwedzkiego sprzymierzeńca w bitwie pod Połtawą w okresie wojny północnej, Sicz Zaporoska została rozgromiona przez zwycięską armię rosyjską.

„Gwoździem do trumny” kozackiej niezależności okazał się koniec wojen Rosji z Turcją, toczonych przez obie potencje na przełomie lat sześćdziesiątych i siedemdziesiątych XVIII w. Kiedy ustały najazdy Turków i podległych im Tatarów, Kozacy 
przestali być potrzebni rosyjskiemu „protektorowi” jako zasłona przeciw islamskiemu naporowi z południa, a stali się jako dumna i broniąca swej samorządności wspólnota - przede wszystkim problemem administracyjnym dla państwa carskiego samodzierżawia. Ukazem carycy Katarzyny II w roku 1775 samodzielność Siczy Zaporoskiej została zlikwidowana. Część Kozaków uszła za Dunaj, a część przeniosła się w okolice Kaukazu Północnego, na terytorium nazywane Kubaniem. Władza hetmanów kozackich traciła znaczenie, a po przyjęciu przez Rosję w 1781 r. ukazu o utworzeniu guberni, Hetmańszczyzna ostatecznie przestała istnieć.

Okres XVI-XVIII w. to zarazem czas rozkwitu ruskiej kultury, mającej wpływ na wykształcenie się odrębnej - rusińskiej (ukraińskiej) - tożsamości etnicznej. W XVII stuleciu prężnie działały szkoły we Lwowie i w Kijowie. Rozwijało się kronikarstwo, poświęcone m.in. powstaniom kozackim. Najwybitniejszymi postaciami ruskiej kultury w kolejnym stuleciu byli: humanista, moralista, filozof, poeta i bajkopisarz Hryhorij Skoworody oraz Iwan Kotlarewski, animator ukraińskiego teatru i autor niecodziennej wersji Eneidy z 1789 r., w którym umiejscowił bohaterów poematu w realiach kozackiego życia, zachowując główne wątki i przygody, opisane przez Wergiliusza.

W końcu XVIII i początkach XIX stulecia tereny dzisiejszej Ukrainy - większość dawnych ziem ruskich Korony i Chanat Krymski (wcześniej lennik osmańskiej Turcji) - znalazły się w wyniku rozbiorów Rzeczypospolitej i ekspansji Rosji w granicach monarchii Romanowów. Jedynie niewielki zachodni skrawek dawnej Rusi Czerwonej ze Lwowem - tzw. Galicja Wschodnia - padł łupem austriackich Habsburgów.

Rosja uznawała Rusinów za szczep narodu rosyjskiego, konsekwentnie odmawiając im prawa do odrębności narodowej. Spośród rodzących się wśród nich nurtów politycznych i kulturowych tolerowała jedynie lojalny wobec Rosji i caratu 
ruch moskalofilski, represjonując te środowiska ideowe, które dążyły do wzmocnienia i rozwoju poczucia rusińskiej (ukraińskiej) tożsamości etnicznej. Instrumentem mającym służyć zdławieniu rodzącej się narodowej samoidentyfikacji Ukraińców miała być również likwidacja w 1839 r. Kościoła unickiego - którego kapłani i wierni przymuszeni zostali do utajnienia kultu - oraz zmuszanie jego wyznawców do przejścia na prawosławie. Z kolei w Cesarstwie Austriackim, przekształconym w latach sześćdziesiątych XIX w. (po klęsce poniesionej przez Wiedeń w wojnie z Prusami o prymat wśród państw niemieckich) w liberalną, dualistyczną monarchię austro-węgierską, „arcykatoliccy” Habsburgowie wspierali bliskich katolicyzmowi ukraińskich unitów, a nawet w ograniczony sposób narodowy ruch ukraiński, dążąc do skonfliktowania go z polską irredentą (np. w okresie Wiosny Ludów 1848 r.) i sprawowania rządów w zaborze austriackim zgodnie ze starorzymską zasadą divide et impera.

Ostoją narodowej tożsamości ukraińskiej w monarchii Romanowów i Habsburgów stawała się rodzima kultura. W okresie romantyzmu w zaborze austriackim jej piewcami byli Markijan Szaszkewycz, Iwan Wahylewycz i Jakiw Hołowacki, czyli tzw. Ruska Trójca. Zajmowali się oni zbieraniem wśród ludu ukraińskiego pieśni ludowych, baśni i legend. Z kolei pod panowaniem rosyjskim narodowy charakter nadał literaturze ukraińskiej Taras Szewczenko, poeta, malarz i ideolog rodzącego się narodu. W 1840 r. w Petersburgu wydał on tom utworów poetyckich pt. Kobziarz, mający charakter literackiego manifestu. Indywidualnością w życiu kulturalnym i literackim stał się również Pantelejmon Kulisz - powieściopisarz, krytyk literacki, historyk i etnograf, tłumacz Szekspira, Schillera i Goethego, autor pierwszej ukraińskiej powieści historycznej pt. Czorna rada (1857). W latach sześćdziesiątych i siedemdziesiątych XIX w. wprowadzono na Ukrainie Nad- 
dnieprzańskiej, pozostającej pod jarzmem rosyjskim, ograniczenia w publikowaniu w języku ukraińskim. Zakazy i ograniczenia ze strony rządu carskiego zahamowały rozwój rodzimej literatury, ograniczając możliwości jej rozwoju do obszarów austriackiej Galicji.

U schyłku XIX stulecia na Ukrainie Naddnieprzańskiej wśród inteligencji zaczął się intensywnie rozwijać kulturalny nurt realizmu. Za najwybitniejszego ówczesnego pisarza ukraińskiego uważany jest Iwan Neczuj-Lewycki - autor nowel, utworów dramatycznych, recenzji teatralnych, prac krytycznoliterackich i powieści historycznych. Pisał przede wszystkim o życiu ukraińskiego chłopstwa, prowincjonalnego duchowieństwa oraz inteligentów. Najwyższym autorytetem moralnym postępowej inteligencji stał się natomiast Mychajło Drahomanow - myśliciel i historyk, etnograf, publicysta i działacz społeczny. Na drugą połowę XIX w. przypadł też rozwój ukraińskiego dramatu. Koryfeuszami ukraińskiego teatru - autorami sztuk scenicznych, reżyserami, a zarazem organizatorami i uczestnikami trup aktorskich stali się Marko Kropywnycki i Mychajło Starycki. Aktywnie działały w Galicji związki oświatowe: „Proświta” oraz Naukowe Towarzystwo im. Szewczenki we Lwowie (w którym rej wodził m.in. znany ukraiński historyk i polityk, Mychajło Hruszewski). O swą pozycję w ukraińskiej kulturze walczyło również z powodzeniem pokolenie lat siedemdziesiątych XIX stulecia, na czele z Iwanem Franko - myślicielem, pisarzem, poetą, uczonym, działaczem politycznym.

W początkach XX w. próbę odnowy literatury ukraińskiej w Galicji podjęli pisarze z kręgu Mołoda Muza, działający przy redakcji gazety „Swit” we Lwowie. Zorientowani cywilizacyjnie na zachodnie prądy głosili hasła Sztuki czystej, nawiązując zarazem do filozofii Schopenhauera. Pozycję propagatora i obrońcy wartości ukraińskiej kultury zyskał Bohdan Łepki, 
profesor literatury ukraińskiej na krakowskim Uniwersytecie Jagiellońskim. Na przełomie wieków znana stała się również poetka, krytyk literacki i publicystka Łesia Ukrainka. Gruntownie wykształcona, zaangażowana w życie polityczne, była jednocześnie autorką dramatycznych poematów, literackich szkiców i dialogów.

Przełom XIX i XX w. był także okresem wielkiego ożywienia politycznego wśród Ukraińców w zaborze austriackim i nad Dnieprem. Uformowały się główne ukraińskie środowiska polityczne - socjaliści Semena Petlury i Wołodymyra Wynnyczenki oraz narodowcy - którzy na terenie Galicji Wschodniej coraz wyraźniej demonstrowali swoje antypolskie nastawienie.

Nowy, burzliwy rozdział przyspieszonego dojrzewania świadomości narodowej w dziejach Ukraińców otworzyła I wojna światowa. W Galicji we Lwowie w 1914 r. powstała Główna Rada Ukraińska, która 6 sierpnia ogłosiła zaciąg do Legionu Ukraińskich Strzelców Siczowych. W tym samym roku ukonstytuował się we Lwowie także Związek Wyzwolenia Ukrainy. Przejściowa rosyjska okupacja Galicji Wschodniej w pierwszych miesiącach 1915 r. zaowocowała próbami rusyfikacji i deukrainizacji prowincji. Po wybuchu w Rosji rewolucji lutowej w 1917 r., w Kijowie w marcu powstała Ukraińska Centralna Rada, która zwołała miesiąc później Ukraiński Kongres Narodowy. W czerwcu Rada proklamowała powstanie autonomii ukraińskiej i utworzenie autonomicznego rządu. Zaczęto formować oddziały Strzelców Siczowych, które wraz z tzw. Wolnym Kozactwem miały stać się nową ukraińską siłą zbrojną. Gdy po październikowym puczu W. Lenina, Rada odmówiła podporządkowania się nowemu „czerwonemu” rządowi i 20 listopada 1917 r. proklamowała powstanie niepodległej Ukraińskiej Republiki Ludowej (URL), ukraińscy bolszewicy ogłosili miesiąc później w Charkowie utworzenie marionetkowej Ukraińskiej Ludowej Republiki Rad, 
sterowanej w istocie z Piotrogrodu. Na jego polecenie oddziały bolszewickie na Ukrainie ruszyły na zachód i południe, zajmując w początkach 1918 r. Kijów i Odessę. Napaść na Ukrainę bolszewicy przedstawiali przy tym jako ukraińską wojnę domową (podobne tłumaczenia i ,interpretacje” agresywnych kroków Moskwy miały stać się później normą w polityce zagranicznej Związku Sowieckiego i postsowieckiej Rosji, czego dowodzi obecny konflikt na wschodzie Ukrainy).

Po serii porażek, poniesionych w walce z wojskami bolszewików, nowy rząd URL przeniósł się na Wołyń i zwrócił się o pomoc do Państw Centralnych - Niemiec i Austro-Węgier. W marcu 1918 r. zawarły one z bolszewicką Rosją i URL tzw. traktat brzeski, w którym rząd URL zrzekł się pretensji do zamieszkiwanych przez Ukraińców terenów Galicji Wschodniej, wchodzących w skład Austro-Węgier, natomiast Rosja uznała, że wymieniona w traktacie URL nie jest związana żadnymi obowiązkami wobec Rosji, która też miała nie wtrącać się w wewnętrzne sprawy swego nowego południowo-zachodniego sąsiada. Rządzący Rosją bolszewicy zobowiązali się również do zawarcia pokoju z URL, wycofania z jej terytorium podlegających im wojsk oraz zaprzestania wszelkich działań przeciwko organom ukraińskiej władzy.

Jednak w miejsce bolszewików na Ukrainę wkroczyły wojska niemieckie i austro-węgierskie, a dawny oficer carski Pawło Skoropadski z poparciem Niemców dokonał zamachu stanu, obwołał się hetmanem, ogłosił likwidację URL i proklamował powstanie tzw. Państwa Ukraińskiego (Hetmanatu), które w historiografii doczekało się niejednoznacznych ocen - obok podkreślających działania P. Skoropadskiego na rzecz rozwoju ukraińskiego szkolnictwa, także konstatujących marionetkowy, proniemiecki charakter jego rządów. W odpowiedzi na zamach, w listopadzie 1918 r. odbyło się w Kijowie spotkanie niechętnych Skoropadskiemu przedstawicieli ukraińskich partii, które powo- 
łały do życia Dyrektoriat URL i ogłosiły rozpoczęcie antyhetmańskiego powstania. W konsekwencji wojska wierne samozwańczemu hetmanowi zostały pobite, a w grudniu oficjalnie ogłoszono przywrócenie Ukraińskiej Republiki Ludowej.

Po faktycznej kapitulacji Niemiec na froncie zachodnim, podpisanej 11 listopada 1918 r., rząd bolszewicki jednostronnie uznał traktat brzeski za niebyły i równolegle do wycofywania się wojsk niemieckich z Ukrainy, rozpoczął zajmowanie opuszczanych przez nie obszarów. Równocześnie, 30 listopada 1918 r., w Moskwie utworzony został - w celu zamaskowania faktycznej agresji ze strony „czerwonej” Rosji - Tymczasowy Robotniczo-Chłopski Rząd Ukrainy, kierowany przez bolszewika Jurija Piatakowa. Z kolei w ramach Rosyjskiej Komunistycznej Partii (bolszewików) wyodrębniono jej nowy oddział - Komunistyczną Partię Ukrainy (bolszewików).

W styczniu 1919 r. Armia Czerwona zajęła Charków (który stał się pierwszą siedzibą rządu i stolicą Sowieckiej Ukrainy), a bolszewicki Rząd Tymczasowy uchwalił połączenie Ukrainy z Rosją na zasadach sowieckiej federacji, sam przemianowując się na Radę Komisarzy Ludowych Ukraińskiej Socjalistycznej Republiki Sowieckiej (USRS). W iście ekspresowym tempie, już w marcu, światło dzienne ujrzała konstytucja nowej sowieckiej republiki. Równocześnie ziemie ukraińskie zaczęły zajmować tzw. Siły Zbrojne Południa Rosji, dowodzone przez „białego” generała Antona Denikina, atakujące w kierunku Moskwy. Natomiast na Wołyń wkroczyły z zachodu wojska polskie, toczące równolegle w Galicji Wschodniej boje z siłami Zachodnioukraińskiej Republiki Ludowej (ZURL), proklamowanej w listopadzie 1918 r., a rządzonej przez Ukraińską Radę Narodową, kierowaną przez Jewhena Petruszewycza. Wojska ZURL zostały wyparte z Galicji przez Polaków w lipcu 1919 r. Władze i ostatnie walczące oddziały Ukraińskiej Republiki Ludowej, próbujące stawiać heroiczny opór jednocześnie bolszewikom, „białym” 
i siłom zbrojnym odradzającej się Rzeczypospolitej, znalazły się w tragicznej sytuacji. Ostatecznie w tym samym czasie, gdy Polacy zdobyli Galicję Wschodnią, za polskimi liniami znalazły schronienie szczątki ściganych przez Armię Czerwoną wojsk URL pod wodzą Wielkiego Atamana Semena Petlury.

Niedawny przeciwnik miał stać się dla Ukraińców sojusznikiem „ostatniej szansy”. Wspólne polsko-ukraińskie uderzenie na pustoszące Ukrainę wojska bolszewickie było dla ówczesnego polskiego Naczelnika Państwa i Wodza Naczelnego Józefa Piłsudskiego próbą stworzenia w Europie Wschodniej federacyjnego państwa, opartego na politycznym, wojskowym i gospodarczym porozumieniu Warszawy i Kijowa. Według Komendanta szansą na utrzymanie przez Rzeczpospolitą świeżo wywalczonej niepodległości było stworzenie wielonarodowego federacyjnego związku państwowego, w którym widział miejsce dla Litwy i Białorusi, a przede wszystkim dla Ukrainy. Urzeczywistnienie tego planu miało zapewnić nie tylko bezpieczeństwo Polsce, ale także Ukrainie, izolując od siebie Rosję i Niemcy.

Jednak, aby żołnierze w polskich i ukraińskich mundurach mogli w przyszłości wspólnie przedefilować ulicami Kijowa, Polacy i Ukraińcy musieli przejść daleką drogę - od wspomnianej już wcześniej wojny w Galicji (Małopolsce) Wschodniej, przez wypracowywanie trudnego politycznego kompromisu w obliczu sowieckiego zagrożenia, aż po autentyczne braterstwo broni, zrodzone na polach bitew $\mathrm{z}$ bolszewickim imperializmem. Dnia 22 kwietnia 1920 r. zostały sfinalizowane negocjacje pomiędzy polskim Naczelnikiem Państwa i ukraińskim przywódcą. Podpisany sojusz polityczny i wojskowy, który mógł stać się wstępem do upragnionej federacji, oznaczał trudny, lecz korzystny dla obydwu stron kompromis. Józef Piłsudski zdecydował się rzucić Wojsko Polskie przeciw okupującej Ukrainę Armii Czerwonej i dopomóc w restauracji ukra- 
ińskiego państwa. Liczył przy tym, że ofensywa na Kijów zmusi Sowietów - przygotowujących wielkie natarcie na północnej części frontu - do ściągnięcia wszystkich sił nad Dniepr w celu zatrzymania sił polsko-ukraińskich. Wielki Ataman S. Petlura - pomimo sprzeciwu antypolsko nastawionych Ukraińców spod znaku ZURL - zrzekł się na rzecz Rzeczypospolitej Galicji Wschodniej, części Wołynia, Chełmszczyzny i Podlasia. Sojusznicy zobowiązali się również do przestrzegania w przyszłości praw narodowo-kulturalnych Ukraińców w Polsce i Polaków na Ukrainie.

W dniu 25 kwietnia ruszyła na Dniepr wielka ofensywa polskich armii, wspieranych przez oddziały S. Petlury - rozpoczęła się „wyprawa kijowska”. Dzień później J. Piłsudski wydał odezwę Do wszystkich mieszkańców Ukrainy, w której deklarował, że polskie wojska usuną z ziem ukraińskich „obcych najeźdźców” i pozostaną na nich jedynie „przez czas potrzebny na to, aby władzę na ziemiach tych mógł objąć prawy rząd ukraiński”. Wojenny pochód na Kijów zakończył się spektakularnym sukcesem - w ciągu niespełna dwóch tygodni swoistego polsko-ukraińskiego „blitzkriegu” sojusznicy rozbili, zepchnęli w walkach za Dniepr lub zmusili do wycofania się na wschód dwie sowieckie armie i opanowali stolicę Ukrainy.

Na zbudowanie zrębów suwerennej ukraińskiej republiki nie starczyło jednak czasu. Wobec groźby utraty kontroli nad Ukrainą nastąpiła w Rosji mobilizacja ponad ideowymi podziałami. Do walki z „polskim najazdem” i wstępowania w szeregi Armii Czerwonej bolszewików i „białych” oficerów wzywali ramię $w$ ramię Lenin i byli carscy generałowie, na czele $z$ legendą z czasów I wojny światowej, dowódcą ostatniej wielkiej rosyjskiej ofensywy w 1917 r., Aleksiejem Brusiłowem. W lecie 1920 r. sowiecki kontratak zepchnął polskie armie i bijące się u ich boku oddziały petlurowców pod Warszawę, stawiając pod 
znakiem zapytania już nie tylko ideę odbudowy Ukrainy czy koncepcję federacji, ale niepodległy byt Rzeczypospolitej.

O losach wojny zdecydował sierpniowy „Cud nad Wisłą” i wrześniowa batalia nad Niemnem - operacje, w ramach których wojska polskie i ukraińskie najpierw rozgromiły potężne siły bolszewików, skoncentrowane na przedpolach stolicy Polski, a następnie odrzuciły je na wschód, osiągając linie obsadzane przed „wyprawą kijowską". Jesienią 1920 r. na froncie wytworzyła się sytuacja patowa - ani wycieńczone i wykrwawione siły polsko-ukraińskie, ani porozbijana w kampaniach nad Wisłą i Niemnem Armia Czerwona nie były w stanie podjąć działań ofensywnych i zadać przeciwnikowi decydującego ciosu.

W tej sytuacji doszło do negocjacji, które zakończyły się podpisaniem 18 marca $1921 \mathrm{r}$. w Rydze - stolicy neutralnej Łotwy - polsko-sowieckiego traktatu pokojowego, na mocy którego Rzeczpospolita (po opanowaniu Wileńszczyzny z Wilnem) objęła w posiadanie Wołyń, Polesie i Małopolskę Wschodnią, natomiast centralna i wschodnia Ukraina pozostała w rękach bolszewików, tworząc ukraińską republikę sowiecką, związaną $\mathrm{z}$ „czerwoną” Rosją. Uznanie przez Polskę USRS - która znalazła się zresztą wśród sygnatariuszy ryskiego porozumienia przekreśliło federacyjne plany J. Piłsudskiego i nadzieje S. Petlury na odbudowę wielkiej, niepodległej Ukrainy nad Dnieprem. Państwu polskiemu nie starczyło sił, by doprowadzić do restauracji władzy URL, a następnie stworzenia $z$ nią federacji, stabilizującej Europę Wschodnią.

Losy Ukraińców bijących się do końca bohatersko u boku wojsk polskich były smutne. Część z nich - już po zawarciu polsko-sowieckiego rozejmu i ustaniu działań wojennych - jesienią 1920 r. próbowała kontynuować samotną walkę na Ukrainie, korzystając z uzbrojenia, zaopatrzenia i funduszy, jakie nakazał przesyłać im potajemnie J. Piłsudski. Po klęsce tej ostatniej, samodzielnej, rozpaczliwej próby oporu przeciwko bolszewikom, 
żołnierze ukraińscy przeszli granicę Rzeczypospolitej, gdzie trafili do przejściowych obozów. Niektórzy spośród petlurowców pozostali w Polsce, inni emigrowali do Europy Zachodniej lub za Ocean. Sam ataman Petlura został zamordowany w 1926 r. w Paryżu przez sowieckiego agenta. Tak na blisko sto lat skończył się sen Ukraińców o wolnej ojczyźnie. 



\section{- ROZ DZIAt III}

\section{Podzieleni}

Wielka Wojna i jej końcowy rezultat - przegrana Cesarstwa Niemieckiego, rozpad Austro-Węgier oraz pogrążenie się Rosji w chaosie bolszewickiej rewolucji i wywołanej nią wojny domowej - wielu narodom Europy Środkowowschodniej i Wschodniej przyniosły ziszczenie marzeń o własnym, suwerennym państwie. Na niepodległość wybili się Polacy, Finowie, Litwini, Łotysze, Estończycy, Czesi, Węgrzy i Serbowie. Wśród narodów, które - pomimo sprzyjającego ich irredentystycznym ambicjom wyniku „wielkiej wojny o wolność ludów” - nie zdołały zbudować niezawisłej państwowości, znaleźli się Ukraińcy. Zakończenie wielkich batalii wojennych, targających wschodem Starego Kontynentu - I wojny światowej, wewnętrznego krwawego konfliktu w dawnym imperium Romanowów pomiędzy bolszewikami i ich przeciwnikami spod różnych sztandarów, wreszcie wojny polsko-sowieckiej - przyniosło podział ziem, zamieszkiwanych przez Ukraińców, pomiędzy sowiecką republikę ukraińską, zdominowaną początkowo przez nową, „czerwoną” Rosję, a następnie wcieloną do Związku Sowieckiego; Drugą Rzecz- 
pospolitą; Czechosłowację i Rumunię (w której granice trafiły Besarabia i Bukowina).

Jak już wspomniano, Ukraina Naddnieprzańska znalazła się - jako republika sowiecka - w strefie wpływów bolszewickiej Rosji na mocy traktatu ryskiego, podpisanego 18 marca 1921 r. (którego, przypomnijmy, była zresztą sygnatariuszem po stronie Sowietów). Nowa republika liczyła blisko trzydzieści milionów mieszkańców - w tym około dwadzieścia trzy miliony etnicznych, rdzennych Ukraińców. Jej stolicą bolszewicy ustanowili nie historyczny Kijów, lecz Charków, który był w niedalekiej przeszłości siedzibą pierwszej uzurpatorskiej władzy sowieckiej nad Dnieprem.

Do grudnia 1922 r. Ukraińska Socjalistyczna Republika Sowiecka funkcjonowała formalnie jako niezależne państwo, mające własny komisariat spraw zagranicznych i służbę dyplomatyczną, choć pozbawione armii. W końcu 1922 r., po utworzeniu Związku Socjalistycznych Republik Sowieckich, stała się jedną z republik związkowych (największą po hegemonie - Rosyjskiej Federacyjnej Socjalistycznej Republice Sowieckiej). W początkach lat dwudziestych sowieckiej Ukrainie przewodzili (pod kuratelą „czerwonego” Kremla) m.in. Stanisław Kosior i Emanuel Kriwing - sekretarze Komunistycznej Partii Ukrainy (bolszewików) - oraz Bułgar Christian Rakowski, jako przewodniczący ukraińskiej Rady Komisarzy Ludowych.

Po zwycięstwie na Ukrainie bolszewicy rozpoczęli politykę rusyfikacji: wprowadzili język rosyjski w szkołach i na wyższych uczelniach, co wywołało ferment wśród ludności ukraińskiej i niezadowolenie ukraińskich elit. Pomimo uchwalenia tzw. Deklaracji Praw Narodów Rosji, która gwarantowała im nieskrępowany rozwój, równoprawność samookreślenia, aż do odłączenia i utworzenia niepodległego państwa, na Ukrainie już wówczas praktycznie realizowano upowszechniony po kilkunastu latach w ówczesnym Związku Sowieckim, stalinowski model narodo- 
wościowy, polegający na narzucaniu republikom narodowym w ramach związkowego państwa sowieckiego rosyjskiego kierownictwa politycznego i języka rosyjskiego w urzędach, szkołach i we wszelkich dziedzinach sfery publicznej.

Pierwsze miesiące istnienia sowieckiej Ukrainy upłynęły pod znakiem represji politycznych, przeprowadzanych przez jej nowych rządców, wobec rzeczywistych i domniemanych przeciwników władzy bolszewików. Towarzyszył im chaos, wywołany wcześniejszymi działaniami wojennymi, i klęska głodu. Z czasem sytuacja ekonomiczna, jak też polityczna uległy pewnej poprawie i stabilizacji. Wiązało się to z odejściem bolszewików od dewastującej życie gospodarcze doktryny komunizmu wojennego na rzecz Nowej Ekonomicznej Polityki, uwzględniającej - choć w ograniczonym zakresie - możliwość funkcjonowania prywatnej przedsiębiorczości.

Jednocześnie bolszewicy rządzący nad Dnieprem, natrafiwszy na masowy opór Ukraińców przeciwko rusyfikacji, przekonali władze w Moskwie o konieczności zmiany taktyki zarządzania Ukrainą. Począwszy od 1921 r., m.in. pod wpływem znanego rosyjskiego pisarza Władimira Korolenki, przeforsowali oni wprowadzenie nauki języka ukraińskiego na wyższych uczelniach i w szkołach republiki. Już w 1923 r. ogłoszono na Ukrainie równość języka rosyjskiego i ukraińskiego w ramach oficjalnie zadeklarowanej nowej sowieckiej polityki „autonomii kulturalno-narodowej” dla narodów zamieszkujących państwo sowieckie. Komunistyczne władze na Kremlu nakazały powszechną liberalizację podejścia do aspiracji narodowościowych w poszczególnych sowieckich republikach.

Równocześnie rozpoczęto proces „ukorzeniania” aparatu państwowego i partyjnego na Ukrainie. Na lokalne stanowiska partyjne i państwowe zaczęto mianować miejscowych Ukraińców lub przynajmniej osoby pochodzenia ukraińskiego. Władze sowieckie wspierały też propagandę nastawioną na 
kształtowanie postaw Ukraińców, mieszkających poza granicami sowieckiej Ukrainy - w Polsce, Czechosłowacji i Rumunii - w kierunku sprzyjającym republice i jej komunistycznemu ustrojowi.

Zjawisko to wywarło istotny wpływ na rozwój ukraińskiej kultury i kształtowanie się poczucia ukraińskiej tożsamości narodowej nad Dnieprem. Znalazło to wyraz m.in. już nie tylko w dopuszczeniu, ale wręcz nakazie stosowania języka ukraińskiego w korespondencji urzędowej; zwalczaniu analfabetyzmu poprzez naukę czytania i pisania w języku ukraińskim i w będącej wynikiem tego działania ekspansji języka ukraińskiego w szkolnictwie na wszystkich poziomach.

Odgórnie zadekretowana przez rosyjskich bolszewików „ukrainizacja” życia nad Dnieprem doprowadziła w krótkim czasie do wykształcenia się miejscowej, ukraińskiej partyjnej elity, nastawionej - niezależnie od swego przywiązania do „uniwersalnej” marksistowsko-leninowskiej ideologii - na pielęgnowanie odrębności Ukrainy, ukraińskiej tożsamości i odrębności narodowej w ramach Związku Sowieckiego. Wynikało to $\mathrm{z}$ - naiwnego jak się później okazało - wyobrażenia o realnych perspektywach autentycznego partnerstwa pomiędzy poszczególnymi republikami, wchodzącymi w skład ZSRS. „Ukrainizacja” doprowadziła do dynamicznego rozwoju kultury ukraińskiej. Należy tu podkreślić, że paradoksalnie to właśnie pod rządami bolszewickimi, zmierzającymi do zbudowania totalitarnego aparatu państwowego, po raz pierwszy w dziejach Ukraińców ich rodzima, młoda wszak wciąż, kultura nie rozwijała się w konspiracji, w opozycji do państwa lub w najlepszym razie niezależnie od niego, lecz była oficjalnie wspierana przez państwo i jego administrację.

Wśród najważniejszych ukraińskich twórców tego okresu wymienić trzeba przede wszystkim Olgę Kobylańską, Maksyma Rylskiego, Włodzimierza Sosiurę i Pawła Tyczynę. Z kolei 
dumą naddnieprzańskiej kinematografii był reżyser Ołeksandr Dołżenko, określany - jako utalentowany twórca, wizjoner i nowator - mianem konkurenta samego legendarnego Siergieja Eisensteina. Ważną postacią ukraińskiego życia kulturalnego, ale także politycznego, stał się czołowy zwolennik związania kultury ukraińskiej z nowoczesnymi kulturalnymi prądami na zachodzie, pisarz Mikoła Chwylowy.

W pierwszej dekadzie istnienia USRS dzięki względnej swobodzie, tolerancji i wolności w sferze kultury, które wpisane zostały niejako w politykę „ukrainizacji”, nastąpiło nie tylko ożywienie kulturalne wśród ukraińskich elit artystycznych. Oddolnie zawiązywano spontanicznie (choć z konieczną akceptacją władz) liczne stowarzyszenia społeczno-kulturalne i oświatowe, a także kluby dyskusyjne. Ich założyciele, animatorzy i zwykli członkowie musieli rzecz jasna liczyć się z rzeczywistością ustroju sowieckiego i dominacją marksistowsko-leninowskiej ideologii. Często podzielali jej diagnozy i recepty, dotyczące budowy komunistycznego społeczeństwa i państwa, poprzestając jedynie na nadaniu im rodzimego charakteru - fakt, że dopiero władza bolszewicka okazała się pierwszym historycznym „mecenasem” ukraińskiej kultury nabierał tu zresztą siły argumentu, przemawiającego za jej akceptacją i poparciem.

Jednak już lata trzydzieste minionego stulecia stanowiły w dziejach naddnieprzańskiej, sowieckiej Ukrainy nowy, niezwykle tragiczny i ponury rozdział. Po zagarnięciu pełni władzy w ZSRS przez Stalina, ten pojętny „uczeń Lenina” zapoczątkował bezwzględną politykę masowych czystek i represji politycznych, mających umocnić jego osobistą pozycję jedynego dyktatora i prawodawcy sowieckiego imperium; zmierzających do uczynienia z partii komunistycznej, sowieckiego aparatu bezpieczeństwa oraz armii instrumentów bezwzględnego terroru; obliczonych wreszcie na przekształcenie przedstawi- 
cieli wszystkich narodowości, które znalazły się w granicach nowego „czerwonego” imperium, w reprezentantów nowej rasy - bezwolnych „ludzi sowieckich”. Działaniom tym towarzyszyła - paradoksalna w przypadku ideologii marksistowsko-leninowskiej, zgodna za to z koncepcją zaprowadzenia stalinowskiego jedynowładztwa i ekspansji nowego, sowieckiego imperium - gloryfikacja historycznej roli Rosji i jej „samodzierżawców”, której towarzyszyła powtórna rusyfikacja Ukrainy.

Poza czystkami politycznymi USRS wstrząsnęła w latach trzydziestych towarzysząca kolektywizacji i sztucznie wywołana przez Stalina w celu likwidacji chłopstwa - ostatniej wielkiej grupy społecznej, opierającej swój byt na prywatnej własności ziemi klęska głodu (tzw. Wielki Głód - Hołodomor) w latach 1932-1933, której ofiarą padło ponad pięć milionów Ukraińców.

Niejako na marginesie tego sowieckiego „administracyjnego" ludobójstwa rozprawiono się również z duchownymi oraz ukraińskimi intelektualistami, wreszcie - działaczami ukraińskiej partii komunistycznej. To krwawym masakrom młodej ukraińskiej elity politycznej, naukowej i artystyczno-kulturalnej, dokonywanym na polecenie Stalina po 1930 r. zawdzięcza swą ponurą nazwę „Rozstrzelanego Odrodzenia” fenomen wcześniejszego rozkwitu ukraińskiej kultury w latach dwudziestych.

Eksterminowanych liderów bolszewickich, przywiązanych do idei ukraińskiej tożsamości narodowej, która miała być wszak kultywowana w ramach Związku Sowieckiego, zastąpili stalinowscy oprawcy, a wśród nich - Łazar Kaganowicz, Stanisław Kosior i Nikita Chruszczow. Równocześnie W 1934 r. stolicę sowieckiej republiki ukraińskiej przeniesiono do Kijowa, co było jednak nie tyle ukłonem w kierunku ukraińskiej tradycji państwowej, ile prostym sposobem odsunięcia od władzy i wpływów dotychczas kierujących republiką niewygodnych działaczy. Wówczas dokonano też podziału 
państwa na obwody kijowski, charkowski, winnicki, zaporoski i doniecki.

Wywózkom Ukraińców z ojczystej ziemi, wtrącaniu przedstawicieli miejscowej, rodzimej elity do więzień i łagrów, wreszcie egzekucjom towarzyszyła polityka, którą Kreml określał mianem „przyśpieszenia asymilacji Ukraińców z Rosjanami”. Właśnie wtedy w ramach programu ,asymilacji” do wschodnich regionów Ukrainy (obwody charkowski, zaporoski, ługański i doniecki) zaczęto masowo kierować pracowników z Rosji, którzy na stałe osiedlali się na Ukrainie w ramach równoległego ogólnosowieckiego programu - industrializacji „Państwa Rad”.

W świetle powyższych faktów trudno dziwić się dążeniom współczesnej polityki historycznej państwa ukraińskiego, która podkreśla cierpienia ludności Ukrainy w „sowieckim domu niewoli”. W myśl konstruowanych przez nią interpretacji, Ukraińcy stanowią „naród-ofiarę”, a ich martyrologia daje im moralną wyższość nad oprawcami, stanowiąc zarazem legitymizację i uzasadnienie bezwzględnej potrzeby posiadania własnego, niepodległego, zabezpieczającego byt narodu państwa. Wedle części historyków i polityków ukraińskich doświadczenie Hołodomoru mogłoby zostać wykorzystane wręcz do uformowania świadomości historycznej młodego narodu ukraińskiego na wzór współczesnego narodu żydowskiego, odwołującego się do podobnego doświadczenia Holokaustu. W centrum Kijowa wybudowano nawet tzw. Kalinowy Gaj, mający być centralnym miejscem upamiętniającym tę martyrologię. W każdym obwodzie Ukrainy założono ponadto księgi pamięci ofiar Hołodomoru, w których zbierane są i gromadzone dokumenty, zdjęcia i relacje świadków.

Warto tu przypomnieć, że już w 2006 r. Rada Najwyższa Ukrainy określiła wywołanie przez władze sowieckie „Wielkiego Głodu” mianem działania ludobójczego. Z kolei w roku 2010 
kijowski Apelacyjny Sąd Administracyjny uznał Stalina i jego zauszników, odpowiadających w szczególności za politykę wobec Ukrainy w latach trzydziestych, m.in. Wiaczesława Mołotowa i Łazara Kaganowicza za winnych zbrodni ludobójstwa, precyzyjnie określonego w kodeksie karnym Ukrainy. Drogą dyplomatyczną Kijów spowodował podjęcie podobnych rezolucji przez parlamenty Polski, Estonii i Gruzji oraz Kongres Stanów Zjednoczonych. Za ludobójstwo uznały „Wielki Głód” na Ukrainie również rządy lub parlamenty wielu innych państw, m.in.: Argentyny, Australii, Azerbejdżanu, Belgii, Czech, Hiszpanii, Kanady, Kolumbii, Litwy, Łotwy, Meksyku, Mołdawii, Paragwaju, Watykanu i Węgier.

Sowieckiemu uciskowi politycznemu i kulturalnemu, represjom i ludobójstwu towarzyszył ekonomiczny wyzysk Ukrainy. Warto przypomnieć, że konstytucja ZSRS ustalała trzy kategorie budżetów: budżet ogólnozwiązkowy, budżet każdej republiki i budżet miejscowy, dotyczący lokalnych jednostek administracyjnych (guberni, powiatów). Otóż uchwalanie budżetu ogólnozwiązkowego oraz budżetów republik należało jedynie do kompetencji wyższych organów ustawodawczych Związku Sowieckiego, przy czym rządy poszczególnych republik miały tylko prawo układania projektu budżetu swoich republik. Zatem wszystkie dochody podatkowe i niepodatkowe wpływały do jednolitego skarbu sowieckiego, wyższe zaś instancje sowieckie w Moskwie dokonywały podziału tych dochodów pomiędzy budżetem związkowym a budżetami poszczególnych republik. Ocena budżetu najbogatszej w ZSRS republiki ukraińskiej przedstawiała się dla niej w latach trzydziestych bardzo niekorzystnie. Praktyka budżetowa upośledzała Ukrainę. Republika została także pozbawiona wpływów z akcyz, ceł, poczt, telegrafów, telefonów, kolei i pożyczek państwowych.

Ukraińcy stanowili jednocześnie największą mniejszość narodową w odrodzonej, międzywojennej Polsce, liczącą - w za- 
leżności od szacunków poszczególnych badaczy i interpretacji spisów powszechnych z 1921 i 1931 r. - od czterech do ponad pięciu milionów osób, czyli około 15\% ludności mieszkającej w granicach Drugiej Rzeczypospolitej.

W okresie kształtowania się państwa polskiego polityka wobec Ukraińców nie była jednoznaczna. Zwłaszcza na wschodnich terenach Galicji, których przynależność do Polski była przez długi czas niepewna, początkowo podejmowano różne inicjatywy w celu zaspokojenia dążeń ukraińskich. Przykładem jest ustawa z 1922 r., przyznająca szeroką autonomię Małopolsce Wschodniej, przewidująca utworzenie dwujęzycznych samorządów i powołanie uniwersytetu ukraińskiego. Po ostatecznym przyznaniu Galicji Polsce, ustawa ta co prawda nigdy nie została uchylona, ale jej postanowienia nie weszły w życie.

Pomimo że w okresie międzywojnia uprawnienia należne mniejszości ukraińskiej wraz z przyznającymi je traktatami międzynarodowymi były naruszane, Druga Rzeczpospolita słusznie może uchodzić za państwo, w którym prawa obywatelskie nie były przez rządzących systemowo łamane, a działacze ukraińscy mieli możliwość propagowania swoich poglądów. Na straży tej praktyki stała konstytucja marcowa.

Porażka koncepcji federacyjnej, przypieczętowana traktatem ryskim, spowodowała, że od początku lat dwudziestych do wybuchu II wojny światowej następowało stopniowe zaostrzanie kursu wobec mniejszości ukraińskiej, przerywane epizodami liberalizacji (m.in. regulacja sytuacji językowej i praw mniejszości narodowych w postaci lex Grabski z 1924 r., próba polsko-ukraińskiego kompromisu politycznego w 1935 r.). Z drugiej strony wykształcała się tożsamość narodowa Ukraińców, którzy nie byli usatysfakcjonowani statusem mniejszości narodowej, dążąc do własnego, niepodległego państwa - ich ambicje irredentystyczne były zresztą wspierane z zagranicy 
przez Niemcy, Czechosłowację, a nawet Litwę. Polityka państwowa charakteryzowała się m.in. odsuwaniem inteligencji ukraińskiej od udziału w aparacie administracyjnym i ograniczaniem zasięgu oświaty ukraińskiej. Niezamierzonym, pozytywnym skutkiem odsuwania ukraińskich absolwentów szkół wyższych od udziału w administracji państwowej, był bardzo dynamiczny rozwój ukraińskiego ruchu spółdzielczego, w którym znajdowali oni zatrudnienie. Do 1926 r. polityka wobec Ukraińców, w związku z częstymi zmianami rządów, była niekonsekwentna, choć zasadniczo istotny wpływ na nią miała ideologia najpotężniejszego wówczas w Drugiej Rzeczypospolitej polskiego obozu narodowego, dążącego do ich asymilacji narodowościowej.

Po 1926 r. piłsudczycy deklarowali odejście od polityki asymilacji narodowościowej, związanej z tendencjami do wynarodowienia Ukraińców, na rzecz polityki asymilacji państwowej - włączenia ich do administracji terenowej, samorządu terytorialnego, współpracy na niwie działalności społecznej i gospodarczej oraz popierania organizacji ukraińskich pod warunkiem ich lojalności wobec państwa polskiego. W praktyce jednak z czasem również zaczęła dominować polityka asymilacji narodowościowej.

Aktywność elit ukraińskich w latach dwudziestych skupiała się na kontynuacji pracy organicznej zapoczątkowanej jeszcze w czasach monarchii habsburskiej. Działalność spółdzielcza, o której wspomniano wyżej, była realnym narzędziem budowania postaw patriotycznych wśród ludności, zwłaszcza przez zatrudnionych w niej byłych żołnierzy ukraińskich formacji zbrojnych z I wojny światowej.

Charakterystyczny był terytorialny podział mniejszości ukraińskiej w Polsce. Ukraińcy zamieszkujący Galicję Wschodnią byli raczej grekokatolikami, wyróżniali się aktywnością polityczną, świadomością odrębności narodowej, 
ostrością w formułowaniu postulatów narodowych i krytycznym lub wrogim stosunkiem do państwa polskiego. Natomiast ukraińska ludność Wołynia była bardziej skłonna do współpracy z Polakami, koncentrowała się raczej na postulatach społecznych i gospodarczych, wyznawała prawosławie. Ta różnica związana była z przeszłością Galicji - kolebki narodowego ruchu ukraińskiego, pozostającej przed I wojną światową w granicach liberalnej monarchii Habsburgów, popierającej Ukraińców przeciwko Polakom, promującej grekokatolicyzm i Wołynia - przed Wielka Wojną znajdującego się w granicach Rosji, popierającej prawosławie i hamującej narodowe dążenia ukraińskie. W środowiskach ukraińskich na terenie Drugiej Rzeczypospolitej funkcjonowały ugrupowania skrajne - Ukraińska Wojskowa Organizacja (UWO) i Organizacja Ukraińskich Nacjonalistów (OUN). Ogółem w całym okresie 1921-1939 ukraińskie podziemie nacjonalistyczne przeprowadziło prawie sto zamachów, w których zginęło łącznie blisko siedemdziesięciu obywateli Polski międzywojennej: przede wszystkim Ukraińcy i Polacy, ale także Rosjanie oraz Żydzi. Ukraińskie podziemie nacjonalistyczne dokonało także w latach 1921-1939 pięciu zamachów bombowych i prawie dwadzieścia akcji ekspropriacyjnych. Zestawienie nie uwzględnia aktów sabotażu, skierowanych przeciw mieniu publicznemu, społecznemu czy prywatnemu, które były główną pozycją w zestawieniach policyjnych dotyczących działalności UWO i OUN.

Ukraińska Organizacja Wojskowa odpowiadała m.in. za nieudany zamach na samego Józefa Piłsudskiego w 1921 r. we Lwowie; w latach 1922-1923 za akcję sabotażową w Galicji Wschodniej; w 1929 r. za zamachy bombowe we Lwowie na Targach Wschodnich; za nieudany zamach na prezydenta Stanisława Wojciechowskiego w 1924 r. we Lwowie; za polityczne zabójstwo posła Tadeusza Hołówko, wielkiego rzecznika pojednania polsko-ukraińskiego, dokonane 29 sierpnia 1931 r. w Truskaw- 
cu i zamach na ministra spraw wewnętrznych, Bronisława Pierackiego w 1934 r. w Warszawie. Odpowiedzią władz polskich były przeprowadzane pacyfikacje wsi ukraińskich, z których pierwsza nastąpiła w 1930 r., druga - osiem lat później. Po stronie polskiej politykę dialogu z Ukraińcami próbował prowadzić wojewoda wołyński w latach 1928-1938, Henryk Józewski, jednak po jego odwołaniu, w związku z licznymi aktami ataków ukraińskich, w roku 1938 wzmożono represje.

Najważniejszymi partiami i organizacjami politycznymi Ukraińców - obok konspiracyjnych UWO i OUN - w tym okresie były: najliczniejsze i najbardziej wpływowe Ukraińskie Narodowo-Demokratyczne Zjednoczenie (UNDO), legalna partia ukraińska, o programie liberalno-demokratycznym, mająca stałą reprezentację w Sejmie; Ukraińska Partia Socjalistyczno-Radykalna, zalegalizowana partia o charakterze socjaldemokratycznym, popierająca ustrój demokratyczny, a zarazem zdecydowanie wroga wobec systemu komunistycznego; Komunistyczna Partia Galicji Wschodniej (od 1923 r. Komunistyczna Partia Zachodniej Ukrainy) - sekcja Komunistycznej Partii Polski, praktycznie całkowicie infiltrowana przez Związek Sowiecki. Działała nielegalnie, jednakże miała swoich przedstawicieli w Sejmie.

Z kolei Ruś Zakarpacka, ze stolicą i centrum administracyjnym w Użhorodzie, wchodziła od 1918 r. w skład ówczesnej Republiki Czechosłowackiej. Formalnie stanowiła jej autonomiczną część, jednak w rzeczywistości była zarządzana centralistycznie przez rząd praski. Silniejsze tendencje autonomistyczne i odśrodkowe pojawiły się wśród zamieszkujących te tereny Ukraińców w drugiej połowie lat trzydziestych XX w., głównie pod wpływem OUN. Wzmocniło je osłabienie pozycji rządu centralnego republiki czechosłowackiej, które było wynikiem układu monachijskiego z września 1938 r. W dniu 8 października 1938 r. przedstawiciele wszystkich niepodległościowych 
rusińskich (ukraińskich) ugrupowań Rusi Zakarpackiej proklamowali oficjalnie autonomię tego kraju w ramach nowej republiki Czesko-Słowackiej (dwa dni wcześniej swą autonomię ogłosiła Słowacja). Pod naciskiem III Rzeszy rząd w Pradze musiał ten fakt zaakceptować. Już 11 października 1938 r. stronnictwa niepodległościowe na Zakarpaciu sformowały rząd autonomicznej Rusi Zakarpackiej z Andrzejem Borodijem jako premierem. Pod koniec tego miesiąca został on jednak aresztowany przez władze czesko-słowackie za otwarcie wyrażane poparcie dla aneksji Rusi przez Węgry. Wówczas na czele Rady Ministrów stanął reprezentant stronnictwa rusińskiego, ksiądz Augustyn Wołoszyn.

Działając na podstawie tzw. pierwszego arbitrażu wiedeńskiego, w dniu 2 listopada 1938 r. Węgry zajęły południową część Rusi Zakarpackiej ze stołecznym Użhorodem. Zdarzenie to osłabiło prowęgierską orientację wśród Rusinów, w wyniku czego wzrosły wpływy orientacji ukraińskiej (głównie OUN) i rusińskiej (Partii Narodowo-Chrześcijańskiej księdza A. Wołoszyna), działających w koalicji. Rząd Wołoszyna przeniósł się do powiatowego miasteczka Chust. Próbując wzmocnić pozycję Rusi Zakarpackiej podpisał umowy handlowe z Niemcami. Równolegle skupił się na rozwijaniu spółdzielczości rolnej i ukraińskiej oświaty. Utworzył również karpackie siły zbrojne - Sicz Zakarpacką. Dnia 22 listopada 1938 r. Zgromadzenie Narodowe Republiki Czesko-Słowackiej uchwaliło nową konstytucję, przyznającą Rusi Zakarpackiej autonomię. Oficjalna nazwa tego autonomicznego kraju od 30 grudnia 1938 r. brzmiała Ukraina Zakarpacka.

Dalsze losy nowego ukraińskiego państwa zostały rozstrzygnięte w efekcie polityki wielkich mocarstw. Nieustanna irredenta węgierska skłoniła hitlerowskie Niemcy do zgody na anektowanie przez Węgry całej Rusi Zakarpackiej. Odpowiednie porozumienie podpisano 11 marca 1939 r. Po ogłoszeniu 
niepodległości przez Słowację (trzy dni później) również Ruś Zakarpacka 15 marca ogłosiła niepodległość, jako Karpato-Ukraina, której prezydentem został ksiądz Wołoszyn. Nie została ona jednak uznana przez żadne inne państwo.

Wcześniej, 13 marca, Adolf Hitler powiadomił rząd węgierski o planowanym wkroczeniu do Czechosłowacji w ciągu następnych 24 godzin oraz zostawił mu wolną rękę w sprawie Karpackiej Ukrainy. Węgrzy natychmiast przedstawili 12-godzinne ultimatum rządowi czechosłowackiemu, w którym zażądali opuszczenia przez wojsko czechosłowackie Karpackiej Ukrainy, zwolnienia węgierskich więźniów politycznych, swobody organizowania się, ochrony węgierskiej własności i wydania broni Węgrom. Rząd czechosłowacki nie wyraził zgody na wydanie broni, zatem dzień później, 14 marca, wojska węgierskie zaatakowały Czechosłowację, w tym Karpacką Ukrainę. Oddziały czechosłowackie i siczowe w walkach zostały zmuszone do wycofania się na teren Rumunii. Do 18 marca organizm państwowy Karpato-Ukrainy uległ całkowitej likwidacji. Ustawą z 23 czerwca 1939 r. parlament węgierski przyłączył Ruś Zakarpacką do Węgier.

W dniu 17 września 1939 r. w rezultacie paktu Ribbentrop-Mołotow Sowiety zajęły wschodnie tereny Polski, zamieszkiwane w większości przez Ukraińców i Białorusinów, a w 1940 r. północną Bukowinę i wschodnią część Besarabii kosztem Rumunii. Kilkadziesiąt tysięcy mieszkańców, uciekając przed sowieckim totalitaryzmem, schroniło się w tym czasie na terenach okupowanych przez III Rzeszę. Na obszarach zajętych przez ZSRS natychmiast podjęła działalność konspiracyjną i zbrojną OUN. Tymczasem w rejonach opanowanych przez Niemców rozpoczęto tworzenie szkolnictwa ukraińskiego, działały również ukraińskie organizacje kulturalne, wydawano ukraińską prasę. Głównym centrum ukraińskiego życia stał się w tym okresie Kraków. Działała tutaj ukraińska 
szkoła oficerska. Tu również w OUN nastąpił rozłam na frakcje banderowców i melnykowców. Banderowcy utworzyli Ukraiński Komitet Narodowy, Wojskowy Ośrodek OUN i specjalną służbę bezpieczeństwa, a następnie Krajowy Sztab Wojskowy. Natomiast $\mathrm{z}$ inicjatywy władz niemieckich powstał Centralny Ukraiński Komitet Narodowy.

Dnia 22 czerwca 1941 r. Związek Sowiecki został zaatakowany przez III Rzeszę, która uprzedziła plany agresji sowieckiej. Zajęte przez Niemców terytorium podzielono następująco: $\mathrm{Ru}-$ munia otrzymała Besarabię i część wybrzeża Morza Czarnego (Transnistria), z terenów Galicji zdobytych na ZSRR utworzono dystrykt galicyjski Generalnego Gubernatorstwa, natomiast z Wołynia i Ukrainy naddnieprzańskiej powstał Reichskommisariat Ukraine. Równocześnie wschodnie tereny Ukrainy objęła „strefa frontowa” pod zarządem wojskowym. Nabytki ukraińskie postawiły na porządku dziennym zagadnienie stosunku Niemców do narodowych aspiracji ukraińskich, generując konflikt pomiędzy zwolennikami koncepcji rabunkowej eksploatacji nowych zdobyczy i traktowania Ukraińców jako „podludzi” - niewolniczej „siły roboczej” (reprezentowanej m.in. przez zarządzającego terenami ukraińskimi Ericha Kocha, SS i, jak pokazała przyszłość, samego Hitlera) oraz entuzjastami pomysłu uczynienia z nich zwasalizowanego sojusznika Niemców w dziele walki z bolszewizmem i Rosją Stalina (którego orędownikiem był ideolog narodowego socjalizmu, Alfred Rosenberg).

Należy tu podkreślić, że w ataku na ZSRS brały udział ukraińskie bataliony Nachtigall i Roland. Z kolei za atakującymi wojskami niemieckimi postępowały grupy pochodne OUN (zarówno banderowców, jak i melnykowców), mające za zadanie przejęcie na zdobytych terenach administracji lokalnej oraz służb porządkowych. W Kijowie melnykowcy zorganizowali tzw. Kureń Kijowski. Niemcy na terenie Ukrainy 
utworzyli przy tym własne formacje policyjne złożone z Ukraińców i Niemców: Ukraińską Policję Pomocniczą i bataliony policyjne. Dnia 30 czerwca 1941 r. we Lwowie została ogłoszona niepodległość Ukrainy. Jednak rzeczywistość obeszła się z niepodległościowymi marzeniami Ukraińców bezwzględnie. Rząd Jarosława Stećki działał nieco ponad tydzień, po czym jego członkowie zostali aresztowani przez Niemców, którzy równocześnie wszczęli represje wobec banderowców, zatrzymując większość działaczy, a resztę zmuszając do powrotu do działalności konspiracyjnej.

Postępowanie Niemców nie zniechęciło części ukraińskich elit politycznych do podjęcia kolejnej próby współpracy z nimi w obliczu nadciągającej na Ukrainę w 1943 r. Armii Czerwonej. Wówczas to z ochotników, pochodzących głównie spod Lwowa, utworzona została 14. Dywizja Grenadierów SS „Hałyczyna”. W 1945 r. podporządkował ją sobie generał Pawło Szandruk, ówcześnie przewodniczący Ukraińskiego Komitetu Narodowego, a zarazem głównodowodzący tzw. Ukraińskiej Armii Narodowej. Formacja została przemianowana na 1. Dywizję Ukraińskiej Armii Narodowej i pod tą nazwą poddała się Amerykanom i Anglikom na początku 1945 r. Przypomnijmy, że do ocalenia Ukraińców przyczynił się wówczas generał Władysław Anders, w tym czasie dowódca II Korpusu Polskiego na froncie włoskim. Jego osobiste wstawiennictwo w Londynie uratowało przed przymusową „repatriacją” do Związku Sowieckiego i prawdopodobną masakrą (która stała się udziałem innych wydanych Sowietom „własowców”), żołnierzy 1. Dywizji. Na wniosek generała Andersa władze brytyjskie uznały ich bowiem za obywateli polskich jakimi według prawa byli, pochodząc z Małopolski Wschodniej, pozostającej przed sowiecką inwazją 17 września 1939 r. w granicach Drugiej Rzeczypospolitej.

Dwa lata wcześniej, w 1943 r., powstała Ukraińska Powstańcza Armia - kultywująca polityczne tradycje OUN - na cze- 
le z Romanem Szuchewyczem, obejmująca swym działaniem przede wszystkim Wołyń, Polesie i Galicję, zwalczająca zarówno sowiecką partyzantkę komunistyczną, jak i polskie podziemie zbrojne oraz nie wahająca się przed eksterminacją cywilnej ludności polskiej na kresach (czego szczytowym paroksyzmem była rzeź wołyńska). Od 1944 r. - wraz z postępami nadciągającej ze wschodu Armii Czerwonej - partyzantka ukraińska zwalczana była przez wojska sowieckie i stalinowski aparat bezpieczeństwa. Przeciwko zbliżającej się ze wschodu, w pogoni za wycofującymi się Niemcami, Armii Czerwonej, NKWD i partyzantce sowieckiej, w obronie "Samostijnoj Ukrainy” wzięło łącznie udział, w szeregach UPA, blisko 60 tysięcy bojowników, przede wszystkim w zachodniej i centralnej części kraju. Toczyli regularne bitwy z sowiecką armią i oddziałami NKWD, z powodzeniem atakowali ich konwoje i siedziby sowieckich władz rejonowych, skutecznie dezorganizowali państwową administrację. Rozmach antykomunistycznej partyzantki UPA spowodował zorganizowanie przez Sowietów na przełomie lat 1945-1946 wojskowo-milicyjnej akcji przeciwko zbrojnemu podziemiu na Ukrainie, zwanej „Wielką Blokadą”. W jej trakcie masy wojska, sowieckiej bezpieki i milicji otoczyły kordonami miasta i wsie, a równocześnie przeczesywały lasy, zabijając $\mathrm{w}$ walce i rozstrzeliwując lub biorąc do niewoli ponad połowę partyzantów spod znaku tryzuba. Reszta kontynuowała beznadziejną walkę - wykruszając się w wyniku ciągłych starć, denuncjacji i prowokacji sowieckiej agentury - aż do 1960 r., kiedy to została zlikwidowana przez Sowietów ostatnia zbrojna grupa Ounowców.

Historia walki z sowieckim zniewoleniem i próba budowy niepodległego państwa podczas ataku III Rzeszy na Związek Sowiecki, zakończona brutalnymi niemieckimi represjami, pozwala zrozumieć, dlaczego UPA współcześnie, w obliczu agresji Rosji, sięgającej po schedę po Sowietach, jest gloryfiko- 
wana przez część Ukraińców - zwłaszcza na zachodzie państwa, gdzie żywa jest pamięć i tradycje polityczne OUN. We współczesnej świadomości obywateli Ukrainy wciąż trwa charakterystyczne przeciwstawienie ofiary krwi złożonej przez ukraiński antykomunistyczny - i antypolski - ruch narodowy oraz przez Ukraińców walczących w szeregach sowieckiej Armii Czerwonej przeciwko niemieckiej inwazji.

Sowieckie represje objęły również ludność cywilną, szczególnie ukraińską inteligencję i duchownych greckokatolickich. Ukraińców traktowano jako naród odpowiedzialny za podjecie kolaboracji z Niemcami. Walce z ukraińskim podziemiem i pacyfikowaniu cywilów towarzyszyły na terenach ukraińskich czystki etniczne - przesiedlenie niemieckich kolonistów, Tatarów, Polaków, Żydów i Czechów. W drugiej połowie lat czterdziestych, w ramach akcji „Wisła”, Ukraińcy zostali wysiedleni z południowo-wschodnich obszarów rządzonej przez komunistów Polski na jej ziemie zachodnie.

Aktywność irredentystyczna Ukraińców - siłą rzeczy zespolona z działaniami niemieckimi, które dawały im cień szansy na niepodległość - jest (podobnie jak martyrologia z okresu sowieckiego) elementem polityki historycznej współczesnego państwa ukraińskiego. Na pozytywny wzorzec patriotycznych postaw wybrano walkę na dwa fronty prowadzoną przez OUN i UPA z dwoma największymi totalitarnymi reżimami, czyli z ZSRR, a później z III Rzeszą. OUN i UPA przedstawiane są przy tym - idealistycznie - jako organizacje demokratyczne i przychylne wieloetnicznej Ukrainie, sojusznik zachodnich aliantów. Uczestników nacjonalistycznego podziemia prezentuje się jako bohaterów gotowych bezinteresownie oddać życie za niepodległość Ukrainy, walczących jakoby na terenie całego kraju w jego współczesnych granicach. Podczas kadencji W. Juszczenki jego administracja dokonywała licznych aktów gloryfikacji OUN i UPA oraz ich poszczególnych działaczy. Praktyka 
ta powróciła w 2014 r. po obaleniu reżimu Janukowycza. Do licznych upamiętnień ukraińskich nacjonalistów dochodzi także na szczeblu lokalnym.

Po II wojnie światowej terytorium Ukrainy znalazło się w granicach ZSRS. Po śmierci Stalina i objęciu władzy w Związku Sowieckim przez N. Chruszczowa nastąpił częściowy powrót do polityki promowania ukraińskości, której korzenie sięgały „proukraińskiej” polityki Kremla z lat II wojny światowej (powołanie republikańskich komisariatów spraw zagranicznych i obrony, ustanowienie w 1943 r. orderu Bohdana Chmielnickiego). W 1954 r., w rocznicę umowy perejasławskiej, do Ukrainy został włączony Krym. W latach 1963-1972 funkcję I sekretarza KPU pełnił Petro Szelest, który dążył do zwiększenia samodzielności ukraińskiej republiki, zwłaszcza w dziedzinie gospodarczej. Zyskał przy tym poparcie inteligencji ukraińskiej. Po „okresie Szelesta” nowym „niezatapialnym” I sekretarzem ukraińskiej partii komunistycznej został Wołodymyr Szczerbyćkyj, postrzegany jako przeciwieństwo poprzednika i wróg ukrainizacji na każdej płaszczyźnie (choć zabiegający o materialne interesy republiki na Kremlu). Jego rządy w Kijowie - a sprawował je aż do czasów M. Gorbaczowa w latach osiemdziesiątych - charakteryzował napływ Rosjan na Ukrainę, ekspansja języka rosyjskiego i „wypłukiwanie” rodowitych Ukraińców z szeregów miejscowej elity politycznej, naukowej i kulturalnej.

Rusyfikacja Ukrainy i totalitarny ucisk generowały postawy buntu przeciw rosyjskiej dominacji, a zarazem komunistycznemu ustrojowi - przede wszystkim wśród ukraińskiej inteligencji. Od schyłku lat pięćdziesiątych następowało formowanie się środowisk i mniej lub bardziej formalnych ruchów dysydenckich, kontestujących sowiecką rzeczywistość. W 1959 r. zaczęła działać grupa o nieoficjalnej nazwie Szistdesiatnyky (nazwa pochodziła od lat sześćdziesiątych, kiedy to przejawiała ona 
największą aktywność), której członkowie wywodzili się spośród ukraińskiej elity twórczej. Podjęła ona inicjatywę odrodzenia języka i kultury ukraińskiej, ich obrony przed rusyfikacją, a także przywrócenia Ukraińcom zapomnianego rodzimego dorobku literackiego - zarówno klasyków, jak i reprezentantów „Rozstrzelanego Odrodzenia” sprzed II wojny światowej. Aktywiści grupy zorganizowali podstawy niezależnego ruchu wydawniczego, zakładali też półoficjalne instytucje kulturalne. Inicjowali także protesty przeciwko polityce narodowościowej Związku Sowieckiego oraz łamaniu praw człowieka. Do najbardziej znanych przedstawicieli tego środowiska należą poetka i tłumaczka Lina Kostenko oraz poeta, a zarazem dziennikarz Wasyl Symonenko.

W 1976 r. powstała Ukraińska Grupa Helsińska (UGH Ukraińska Społeczna Grupa na rzecz Wykonania Porozumień Helsińskich), która przyjęła za podstawę swej działalności Akt Końcowy Konferencji Bezpieczeństwa i Współpracy w Europie z 1975 r., zobowiązujący jego sygnatariuszy - wśród nich również Związek Sowiecki - do poszanowania praw człowieka i podstawowych wolności oraz podkreślający równouprawnienie i prawo narodów do samostanowienia. Liderem organizacji - liczącej około czterdziestu osób - został poeta Mykoła Rudenko. Grupa wydała liczne deklaracje, apele i inne dokumenty w obronie praw człowieka na Ukrainie. Od 1979 r. zaczęło również działać jej Przedstawicielstwo Zagraniczne w Stanach Zjednoczonych. Członkowie UGH stali się niestety celem bezprawnych represji sowieckich władz - zastraszeń, zatrzymań, aresztowań i przesłuchań. W początkach lat osiemdziesiątych wszyscy działacze Grupy przebywali w więzieniach lub łagrach bądź znaleźli się na emigracji.

Na początku 1988 r. Grupa wznowiła swą działalność na Ukrainie, przekształcając się zarazem w Ukraiński Związek Helsiński (UZH). Jego przewodniczącym został prawnik Łew- 
ko Łukjanenko - niejako zaocznie, gdyż odbywał wówczas karę łagru. Obok Łukjanenki do czołowych działaczy i liderów UZH należeli dziennikarz, krytyk literacki i publicysta Wiaczesław Czornowił oraz bracia Mychajło i Bohdan Horyń. Środowisko Związku skupiało około tysiąca aktywnych, „kadrowych” członków i kilkadziesiąt tysięcy sympatyków. W 1990 r. UZH rozwiązał się i ogłosił swym następcą i spadkobiercą Ukraińską Partię Republikańską.

W drugiej połowie lat osiemdziesiątych zapoczątkowany został łańcuch wydarzeń, których bezpośrednim finałem miało stać się - jak określali to później historycy i publicyści znad Dniepru - wyjście Ukrainy z sowieckiego „domu niewoli” i wybicie się na niepodległość. Dojście do władzy w Związku Sowieckim Michaiła Gorbaczowa i zadeklarowana przez niego „pieriestrojka” państwa i nowa polityka „głasnosti” ożywiła w USRS dyskusję nad przestrzeganiem praw człowieka i obywatela, pozycją partii komunistycznej oraz prawem Ukraińców do samostanowienia. Dodatkowo, w roku 1986, świadomością Ukraińców wstrząsnęła awaria elektrowni w Czarnobylu, którą władze z początku starały się bagatelizować. Tymczasem na skutek skażenia około sto tysięcy Ukraińców zmuszonych było do opuszczenia swych miejsc zamieszkania.

Rok później, na fali zapoczątkowanych przez Gorbaczowa reform, rozwinął się nad Dnieprem ruch na rzecz obrony rodzimego dziedzictwa narodowego i kulturowego, przywrócenia publicznej pamięci jego zabytków, rozwoju szkolnictwa na Ukrainie i wprowadzenie w jego ramach obowiązkowej nauki języka ukraińskiego. Dwa lata później program ukraińskich reformatorów został wzbogacony o postulat legalizacji Kościoła greckokatolickiego.

W 1990 r. odbyły się wybory do Rady Najwyższej USRS, które dały mandaty 331 Ukraińcom i 99 Rosjanom, a zwycięstwo komunistom. Rada podjęła uchwałę o suwerenności z zastrze- 
żeniem pozostania w granicach zreformowanego ZSRS. Z konstytucji został usunięty zapis o kierowniczej roli partii komunistycznej. Nastąpiło również podpisanie rosyjsko-ukraińskiego układu o wzajemnym uznaniu suwerenności (w ramach Związku Sowieckiego). W marcu 1991 r. odbyło się ogólnosowieckie referendum o przyszłości ZSRS - za utrzymaniem Związku zagłosowało 70\% jego uczestników przy frekwencji wynoszącej $80 \%$ uprawnionych do głosowania. Po referendum przeprowadzonym przez rosyjskie władze Krymu, gdzie 93\% głosujących opowiedziało się za reaktywowaniem Krymskiej Republiki Autonomicznej w ramach Rosyjskiej SRS, władze ukraińskie nadały Krymowi autonomię.

Po zorganizowanym przez KGB i najwyższą partyjną nomenklaturę tzw. puczu Janajewa z 19 sierpnia 1991 r. Rada Najwyższa USRS proklamowała 24 sierpnia niepodległość Ukrainy. Aby uprawomocnić tę uchwałę, 1 grudnia 1991 r. na Ukrainie przeprowadzono kolejne referendum w sprawie niepodległości. Na karcie do głosowania widniało pytanie: „Czy potwierdzasz akt proklamowania niepodległości Ukrainy?” Frekwencja wyniosła w skali całego kraju ponad $84 \%$, ponad $90 \%$ osób odpowiedziało na pytanie twierdząco. Równocześnie z referendum przeprowadzono wybory prezydenckie, które wygrał były komunista Leonid Krawczuk, pokonując czołową postać antykomunistycznej opozycji, Wiaczesława Czornowiła.

Dodać trzeba, że depozytariuszem myśli niepodległościowej spod znaku tryzuba była - od zakończenia I wojny światowej i rewolucji bolszewickiej w Rosji - ukraińska emigracja. Na przełomie XIX i XX w. kierowała się ona głównie do Stanów Zjednoczonych, Kanady i Brazylii, a także do Francji. Miała przy tym głównie podłoże ekonomiczne. Fale emigracji politycznej następowały po I i II wojnie światowej. Po Wielkiej Wojnie i ustanowieniu sowieckiej Ukrainy ponad sto tysięcy Ukraińców znalazło się w Austrii, Czechosłowacji, Niemczech, 
we Francji i w Polsce. Po II wojnie światowej kraj opuściło blisko ćwierć miliona ludzi (osiedlili się głównie w Stanach Zjednoczonych, Kanadzie, Australii i Wielkiej Brytanii). W latach osiemdziesiątych poza granicami Ukrainy żyło około trzech milionów Ukraińców. Byli oni dobrze zorganizowani, tworząc sieć narodowych stowarzyszeń społeczno-politycznych, m.in. Światowy Kongres Wolnych Ukraińców, Ukraiński Komitet Amerykańskiego Kongresu, Ukraiński Komitet Kanadyjski czy Ukraińską Amerykańską Radę Koordynacyjną. Dysponowali też instytucjami kulturalnymi i oświatowymi, prasą i licznymi wydawnictwami. 



\section{-ROZ \\ DZIAt \\ III}

\section{Od Białowieży do „Pomarańczowej Rewolucji"}

Nowy włodarz Ukrainy już po tygodniu, 8 grudnia 1991 r., podpisał - wraz z prezydentem Rosji, Borysem Jelcynem i przewodniczącym Rady Najwyższej Białorusi, Stanisławem Szuszkiewiczem - porozumienie o likwidacji ZSRS i utworzeniu Wspólnoty Niepodległych Państw (WNP), do której przyłączyły się jeszcze w grudniu inne byłe republiki sowieckie. Zostało ono uzgodnione na Białorusi pod Brześciem w Puszczy Białowieskiej, dzięki czemu przeszło do historii jako „Układ Białowieski”. Porozumienie to głosiło, iż ZSRS jako podmiot prawa międzynarodowego i byt polityczny przestał istnieć, w jego zaś miejsce suwerenne kraje powołują nowy twór - WNP.

Po ogłoszeniu niepodległości i przypieczętowaniu losu totalitarnego sowieckiego imperium, mieniącego się kłamliwie „Krajem Rad” i „Ojczyzną Światowego Proletariatu”, wolna Ukraina stanęła wobec fundamentalnych pytań dotyczących jej ustroju politycznego, ładu społeczno-gospodarczego i ambicji międzynarodowych. Warto przypomnieć, że jako niepodległe państwo zajmowała ona pod względem potencjału gospodarczego i militarnego (dysponowała własnym arsenałem atomo- 
wym, liczącym ponad tysiąc głowic) siódme miejsce na świecie. Była jedną z najbardziej rozwiniętych republik postsowieckich, z przemysłem, kompleksem zbrojeniowym i rolnictwem lepiej prosperującym niż w wielu innych państwach, kształtujących się na terenie byłego ZSRS, wreszcie licznymi kadrami administracyjnymi i naukowymi.

Równocześnie na drodze do politycznego i ekonomicznego sukcesu Ukrainy oraz jej wyjścia z cienia Rosji stanął w latach dziewięćdziesiątych kryzys gospodarczy, który ogarnął wszystkie byłe republiki sowieckie. Był on wynikiem zarówno krachu komunistycznego systemu nakazowo-rozdzielczego i zrywania dotychczasowych więzów ekonomicznych z innymi republikami postsowieckimi (przede wszystkim z Rosją, co było ceną ugruntowania pełnej niepodległości), jak i działań podejmowanych z jednej strony przez Kreml, usiłujący poprzez presję gospodarczą uniemożliwić całkowitą emancypację Kijowa, z drugiej - przez rabunkowe poczynania byłej sowieckiej nomenklatury (przepoczwarzającej się w ukraińską oligarchię), pracę rosyjskiej agentury nad Dnieprem, wreszcie kroki podejmowane przez kremlowskie służby specjalne - grupy i środowiska działające w imię własnych interesów lub na zlecenie Moskwy. Tym niemniej oficjalnie deklarowanym celem władz i większości politycznych elit Ukrainy stała się budowa demokratycznego państwa, obywatelskiego społeczeństwa i gospodarki rynkowej na wzór zjednoczonej Europy Zachodniej, integracja z jej strukturami oraz emancypacja spod politycznych i gospodarczych wpływów Moskwy.

Uwarunkowania wynikające ze spadku po komunizmie nadały jednak kształtującej się ukraińskiej demokracji charakter odmienny od zachodnioeuropejskiego czy amerykańskiego. Brakowało w niej równowagi wynikającej z rywalizacji silnych, równorzędnych partii politycznych. Dotychczasowa opozycja - demokratyczna, niepodległościowa, nacjonalistyczna - była 
zbyt słaba, by w kształtującym się systemie politycznym odgrywać istotną rolę. Brak było również równowagi w relacjach prezydent - parlament. Pozycję dominującą miała głowa państwa. Władza pozostawała w rękach starej nomenklatury, która sprawnie wykorzystywała słabość systemu politycznego, zawłaszczając władzę na Ukrainie. Zrodził się specyficzny model władzy oparty na porządku klanowo-oligarchicznym, skupiającym zarówno władzę polityczną, gospodarczą, jak i medialną.

Równocześnie po rozpadzie ZSRS polityka Rosji wobec Ukrainy sprowadzała się przede wszystkim do przeciwdziałania rozluźnianiu wzajemnych powiązań gospodarczych i politycznych. Cel ten próbowano osiągnąć poprzez rozwój Wspólnoty Niepodległych Państw. Na kształt polityki prowadzonej przez Rosję oddziaływało również poczucie bliskości kulturowej i historycznej. Duże znaczenie miały także silne więzi narodowe oraz obecność licznej mniejszości rosyjskiej na Ukrainie (około 20\%). W latach dziewięćdziesiątych podejmowane przez Kreml próby nakłonienia Ukrainy do włączenia się w procesy integracyjne w obrębie WNP kończyły się jednak niepowodzeniem. Chociaż Ukraina była jednym z założycieli Wspólnoty, to nie podpisała statutu organizacji ani Układu o bezpieczeństwie zbiorowym. Władze ukraińskie generalnie trafnie diagnozowały, że działania Rosji miały na celu jedynie utrzymanie pozycji dominującej nad południowo-zachodnim sąsiadem.

Ponadto w latach dziewięćdziesiątych dochodziło do istotnych sporów pomiędzy Moskwą i Kijowem na tle wojskowej obecności Rosji na Krymie i uregulowania własności Floty Czarnomorskiej. Zostały one, jak się zdawało ostatecznie, rozstrzygnięte dzięki podpisaniu w 1997 r. porozumień o podziale floty i zasadach stacjonowania wojsk rosyjskich w Sewastopolu. Istotnym problemem militarno-politycznym zarówno w stosunkach ukraińsko-rosyjskich, jak i o wymiarze geopolitycznym, budzącym obawy Waszyngtonu i państw Europy 
Zachodniej, była również zasygnalizowana wcześniej kwestia dostępu Ukrainy do broni atomowej, znajdującej się w momencie rozpadu ZSRS na jej terytorium. Została ona uregulowana porozumieniem budapeszteńskim z 1994 r., na mocy którego Kijów zgodził się na przekazanie swego potencjału atomowego Rosji w zamian za zagwarantowanie przez wspólnotę międzynarodową - m.in. Stany Zjednoczone, Wielką Brytanię, Francję i Rosję - niepodległości, suwerenności i granic Ukrainy. Gwarancje te zostały brutalnie pogwałcone przez rosyjską agresję na Krym i wschodnią Ukrainę w 2014 r. W tym samym roku Moskwa wypowiedziała też jednostronnie rosyjsko-ukraińskie porozumienie w sprawie Floty Czarnomorskiej.

Wraz z objęciem urzędu prezydenta Rosji w 2000 r. przez Władimira Putina, zainicjowaniem przez niego faktycznej przebudowy ustroju państwa w kierunku tworzenia reżimu autorytarnego, a na arenie międzynarodowej polityki odbudowy mocarstwowego statusu Rosji i jej wpływów w regionie, stosunki Moskwa-Kijów w ciągu kilku lat zaowocowały konfliktami, spowodowanymi agresywną, rewizjonistyczną polityką Kremla. Oficjalny kurs „zacieśniania współpracy z Ukrainą” (podobnie jak w przypadku Białorusi), będący w istocie kolejną próbą zdominowania sąsiada, miał przy tym dla Moskwy znaczenie fundamentalne, gdyż w przypadku jego sukcesu, mógłby stanowić wzór „reintegracji z Rosją” dla innych państw z obszaru byłego ZSRS. Dla osiągnięcia tego celu Kreml stosował różnorodne metody, m.in. wspieranie przez rząd działań rosyjskich przedsiębiorstw, dążących do przejmowania kontroli nad ukraińskim przemysłem w obliczu niechęci zachodnich inwestorów do ponoszenia ryzyka angażowania kapitału na niestabilnej Ukrainie; podejmowanie prób wykorzystania ukraińskich gazociągów do faktycznego zmonopolizowania przez Rosję tranzytu surowców energetycznych (gazu) do Europy Zachodniej; stosowanie jako elementu presji na Kijów ograniczeń impor- 
towych i ceł zaporowych w handlu z Ukrainą; powołanie do życia tzw. Wspólnej Przestrzeni Gospodarczej, jako instrumentu instytucjonalnego utrwalenia pozycji Rosji (państwa o największym potencjale ekonomicznym w ramach wspomnianego porozumienia) na obszarze posowieckim; opóźnianie przez Kreml uregulowania kwestii delimitacji granicy rosyjsko-ukraińskiej i porozumienia w sprawie podziału Morza Azowskiego i Cieśniny Kerczeńskiej; przeciwdziałanie na arenie międzynarodowej dążeniom Ukrainy do integracji z Unią Europejską (UE) i zbliżenia z NATO; wspieranie finansowe i medialne środowisk politycznych na Ukrainie, opowiadających się za jak najściślejszą współpracą z Rosją.

Na tle polityki Kremla, zmierzającej zdecydowanie do utrzymania Ukrainy w rosyjskiej strefie wpływów, anemicznie rysowały się oferty Zachodu, kierowane pod adresem Kijowa. Pakt Północnoatlantycki zaproponował jej ostrożnie (uwzględniając negatywne stanowisko Rosji wobec planów rozszerzenia NATO na Ukrainę) współpracę w ramach Partnerstwa dla Pokoju, bez konkretnych perspektyw włączenia do euroatlantyckich struktur bezpieczeństwa, realnej pomocy w modernizacji armii i postulatów organizacyjnych oraz personalnych pod adresem ukraińskich sił zbrojnych, które mogłyby stać się katalizatorem ich westernizacji i zmiany mentalności korpusu oficerskiego. Natomiast Unia Europejska, deklarując poparcie dla integracji z Ukrainą, również nie uczyniła nic, aby wywrzeć presję na przeprowadzenie przez Kijów reform koniecznych w celu przeprowadzenia akcesji.

W obliczu zasygnalizowanych wydarzeń i procesów, związanych z poszukiwaniem przez niepodległą Ukrainę bezpieczeństwa i miejsca $\mathrm{w}$ - podlegającym rekonstrukcji po rozpadzie Związku Sowieckiego - regionie Europy Wschodniej; relacjach z Unią Europejską, poszczególnymi państwami Europy Zachodniej, Stanami Zjednoczonymi, a przede wszystkim 
z Rosją, blado wypadła prezydentura L. Krawczuka. Wyniesiony do władzy przez niepodległościową falę początku lat dziewięćdziesiątych, $\mathrm{z}$ racji rozległych prezydenckich prerogatyw ponoszący zasadniczą odpowiedzialność za losy wielkiego państwa, nie potrafił on przekonująco sformułować autorskiego credo politycznego ani działać konsekwentnie na arenie międzynarodowej na rzecz wzmocnienia pozycji Kijowa. Entuzjastyczne recenzje współpracy Ukrainy ze strukturami europejskimi przeplatał z okresowym wspieraniem pomysłów tworzenia wspólnoty eurazjatyckiej pod egidą Rosji bądź zaangażowaniem się Kijowa w pogłębianie integracji ekonomicznej i politycznej w ramach WNP. Za tę niekonsekwencję przyszło mu drogo zapłacić. W wyborach prezydenckich 1994 r. większość Ukraińców, znużona sytuacją „zawieszenia” Kijowa pomiędzy Unią Europejską i Rosją, wolała Leonida Kuczmę, deklarującego jasno potrzebę nawiązania przyjaznych, korzystnych gospodarczo stosunków z Rosją, niż „hamletyzującego” L. Krawczuka.

Szybko okazało się, że za swą wyborczą decyzję Ukraińcy otrzymali słony rachunek. Wyborcze hasła L. Kuczmy „O sojusz z Rosją” i „Naprzód ku przyszłości” okazały się w istocie zapowiedzią politycznego podporządkowania Ukrainy wschodniemu sąsiadowi na arenie międzynarodowej i realizacji programu jej gospodarczego uzależnienia od rosyjskich oligarchów - ściśle powiązanych z kremlowskimi władzami i strukturami siłowymi Rosji - z którego osobiste korzyści czerpać mieli jedynie ich odpowiednicy nad Dnieprem, współpracujący z politycznym obozem nowego prezydenta. Kolejne dekrety L. Kuczmy i ustawy przegłosowywane w ukraińskim parlamencie (gdzie deputowani byli coraz częściej „kupowani” lub wręcz wprowadzani doń dzięki materialnemu wsparciu kampanii przez elitę finansowo-przemysłową albo też sami reprezentowali kręgi oligarchii) przekształcały oficjalnie de- 
mokratyczne i rynkowe państwo w swoistą skorumpowaną oligarchiczną dyktaturę - której eksponentem i gwarantem stref wpływów i podziału „łupów” był prezydent - a zarazem faktyczny rosyjski protektorat. Przyczynił się do tego m.in. dekret o utworzeniu grup finansowo-przemysłowych, sankcjonujący praktyki monopolistyczne, unikania opodatkowania i pranie „brudnych” pieniędzy. Zawłaszczenie państwa przez polityczno-biznesową oligarchię, wszechobecna korupcja oraz brak zasadniczych reform ekonomicznych, finansowych i administracyjnych powodowały w drugiej połowie lat dziewięćdziesiątych staczanie się Ukrainy w coraz głębszy kryzys gospodarczy, przejawiający się spadkiem PKB i produkcji, wzrostem inflacji oraz gwałtownym procesem rozwarstwiania społeczeństwa na nieliczną, coraz bogatszą elitę i ubożejącą w zastraszającym tempie większość obywateli.

Paradoks polegał na tym, że pogorszenie swojej sytuacji materialnej Ukraińcy wiązali z upadkiem komunizmu, odzyskaniem przez Ukrainę niepodległości oraz zerwaniem ścisłych związków gospodarczych z Rosją, wracając z nostalgią do czasów „sowieckiej równości”, podczas gdy odpowiedzialność za pauperyzację ukraińskiego społeczeństwa ponosili z jednej strony właśnie spadkobiercy komunistycznej nomenklatury, uwłaszczający się na narodowym majątku, $\mathrm{z}$ drugiej formalne i nieformalne polityczne, gospodarcze i wojskowo-bezpieczniackie związki z Rosją. Ich personifikacją stał się sowiecki generał KGB, a następnie ukraiński polityk, Jewhen Marczuk. Urodzony na Ukrainie w 1941 r., zwerbowany przez KGB już na przełomie lat pięćdziesiątych i sześćdziesiątych, mianowany w 1990 r. pierwszym zastępcą szefa ukraińskiego KGB, rok później przewodniczącym jego następczyni, czyli Służby Bezpieczeństwa Ukrainy, w 1994 r. - pierwszym wicepremierem, w 1995 r. - premierem ukraińskiego rządu, w latach 1995-1998 posłem do Rady Najwyższej Ukrainy, rok później próbujący sięgnąć nawet po urząd 
prezydenta, uchodził za nieoficjalnego rezydenta środowiska byłej sowieckiej bezpieki i „człowieka Rosji”, posiadającego niebezpieczną dla ukraińskich elit wiedzę o ich działaniach, a co za tym idzie jeszcze większe wpływy.

Mafijne, polityczno-biznesowe powiązania owocowały również gwałtownym wzrostem przestępczości. W zatrważającym tempie zwiększała się liczba spektakularnych zabójstw i afer. W 1995 r. został zamordowany najbogatszy przedsiębiorca na wschodzie Ukrainy, Achat Bragin, rok później - kolejny „pan na Donbasie”, Jewhen Szczerbań (beneficjentami tych mordów okazali się na dwie dekady „najbogatszy Ukrainiec” Rinat Achmetow i „frontman” klanu donieckich polityków i oligarchów, Wiktor Janukowycz). W 1999 r. w Stanach Zjednoczonych został zatrzymany, następnie oskarżony o wymuszenia, oszustwa, pranie „brudnych” pieniędzy i kradzież ponad trzystu milionów dolarów, wreszcie skazany na wieloletnie więzienie, były premier Ukrainy, Pawło Łazarenko.

Jednak ani wspomniane wcześniej afery, ani spektakularne zabójstwa przedstawicieli ukraińskiego establishmentu nie przeszkodziły L. Kuczmie w reelekcji w wyborach prezydenckich, które odbyły się w dwóch turach, 31 października i 14 listopada 1999 r. Jego pozycją jako głowy państwa miała wstrząsnąć dopiero „sprawa Gongadzego”. Jej tragicznym bohaterem był Heorhij Gongadze - dziennikarz specjalizujący się w problematyce politycznej, twórca popularnego nad Dnieprem portalu „Ukraińska Prawda”. Ujawniał on liczne afery polityczne, korupcję i nadużycia na szczytach władzy. Dla rządzącego układu - na czele z L. Kuczmą - H. Gongadze stał się niewygodny, a później wręcz groźny. Po wielokrotnych nieudanych próbach zastraszenia niepokornego żurnalisty, 16 września 2000 r. H. Gongadze wieczorem wyszedł z pracy i zniknął. Jego pozbawione głowy ciało znaleziono dopiero dwa miesiące później. Milicja (która konsekwentnie odmawiała wcześniej przyjęcia zgłoszenia zaginięcia 
dziennikarza) i prokuratura śledztwo prowadziły nieudolnie, starając się nie tyle odkrywać, co zacierać prawdę.

Do przełomu w sprawie doszło, gdy przewodniczący Rady Najwyższej Ukrainy i były konkurent L. Kuczmy w wyborach prezydenckich Oleksander Moroz na forum parlamentu przedstawił potajemnie nagrane taśmy, w których urzędujący prezydent sugerował oficerom ukraińskiej policji „pozbycie się" H. Gongadzego. Wybuchł skandal, a afera taśmowa okazała się katalizatorem społecznego przełomu. Letarg, w jaki zapadli Ukraińcy w początkach lat dziewięćdziesiątych, marazm i zniechęcenie, stanowiące symboliczne odzwierciedlenie swoistego „Zamrożenia” państwa pomiędzy Zachodem i Wschodem, Europą i Rosją, prawdziwą niepodległością i uzależnieniem od Kremla, demokratycznym państwem prawa i folwarkiem mafijnej oligarchii, ustąpiły miejsca obywatelskiemu, społecznemu aktywizmowi. Ulicami ukraińskich miast przechodziły masowe demonstracje. Powstawały również miasteczka protestujących. W parlamencie - co prawda bezskutecznie - usiłowano uruchomić procedurę impeachmentu L. Kuczmy. Do oskarżeń głowy państwa i rządzącej elity o korupcję i ograniczanie wolności słowa doszły zarzuty inspirowania politycznego mordu, a wkrótce także bezprawnej sprzedaży broni poza granice Ukrainy. Towarzyszyły im postulaty systemowej zmiany stosunków społecznych, gospodarczych i politycznych, polegającej na likwidacji ,prezydenckiego autorytaryzmu” i zastąpienia go republiką parlamentarną. Akcję protestacyjną poparło zgodnie ponad dwadzieścia partii politycznych i organizacji społecznych od nacjonalistów do socjalistów. Popularność L. Kuczmy stopniała błyskawicznie z 60 do $20 \%$.

Wobec rozszerzania się protestów i radykalizacji antyrządowych nastrojów ich uczestników, władze w Kijowie przeszły do ofensywy. Prezydent L. Kuczma, ówczesny premier Wiktor Juszczenko (który stanowisko zyskał dzięki udanej reformie 
walutowej, jaką przeprowadził kierując Narodowym Bankiem Ukrainy) i przewodniczący Rady Najwyższej Ukrainy Iwan Pluszcz w głośnym „liście trzech” z 13 lutego 2001 r. potępili protestujących, nie szczędząc im epitetu „faszystów” (już wówczas „użytecznego” w stygmatyzacji przeciwników prorosyjskich władz w Kijowie).

Tego samego dnia została aresztowana liderująca części opozycji Julia Tymoszenko (była wicepremier w rządzie W. Juszczenki, która wespół z nim usiłowała zwalczać szarą strefę w biznesie, a została zdymisjonowana przez L. Kuczmę pod zarzutem malwersacji, w istocie - za walkę z nadużyciami gospodarczymi oligarchicznych klanów: donieckiego i kijowskiego, związanego z samym prezydentem).

Milicja zaczęła rozbijać wiece i demonstracje, aresztując ich uczestników. Równocześnie zdecydowanie rozprawiano się z tymi niepokornymi urzędnikami i dziennikarzami, którzy usiłowali wyjaśnić sprawę zabójstwa i ujawnić powiązania pomiędzy elitami polityczno-biznesowymi i światem przestępczym. W lipcu 2001 r. w lokalu telewizji TOR został śmiertelnie pobity jej dyrektor Ihor Aleksandrow, tropiący związki ukraińskich polityków, prokuratury i milicji z mafią. W październiku 2003 r. L. Kuczma zdymisjonował prokuratora generalnego Ukrainy Swiatosława Piskuna, który usiłował doprowadzić do aresztowania podejrzanych o inwigilowanie H. Gongadzego. Bezwzględność i brutalność prezydenta spowodowały, iż zaczął się od niego dystansować W. Juszczenko, który wystąpił w obronie J. Tymoszenko, zarzucając głowie państwa zaniechanie dialogu z opozycją i wspieranie oligarchicznych klanów. Zapłacił za to dymisją 27 kwietnia $2001 \mathrm{r}$.

Problemy L. Kuczmy pogłębiały skandale międzynarodowe, w jakie zamieszana została Ukraina. Oskarżono go na forum ONZ o nielegalny handel bronią z Macedonią, Chinami i Iranem. W 2001 r., podczas ćwiczeń wojskowych na Krymie, 
wystrzelona rakieta zniszczyła samolot pasażerski. Śmierć poniosło ponad sto sześćdziesiąt osób. Jak się okazało, całkowitą odpowiedzialność za tragedię ponosiło lekceważenie procedur oraz zła organizacja i chaotyczne działanie ukraińskich sił zbrojnych, dowodzonych przez niekompetentnych oficerów i doprowadzonych na skraj upadku przez nieodpowiedzialnych cywilnych zwierzchników.

Zdymisjonowanie przez skompromitowanego L. Kuczmę zasłużonego dla ukraińskiej gospodarki W. Juszczenki i inspirowane przez głowę państwa prześladowania, których ofiarą padła J. Tymoszenko, znana z wystąpień przeciwko ukraińskiej oligarchii, uczyniły z tej dwójki polityków naturalnych trybunów ludowych i liderów antyprezydenckiej opozycji. Przy czym w tym zgodnym politycznym tandemie W. Juszczenko uchodził za rzecznika działań umiarkowanych i koncyliacyjnych, natomiast J. Tymoszenko jawiła się jako charyzmatyczna, radykalna bojowniczka. To ona oświadczyła, że w przyszłych wyborach prezydenckich gotowa jest poprzeć byłego premiera. Ona utworzyła grupę inicjatywną ponad pięćdziesięciu partii i organizacji, domagających się przeprowadzenia referendum w sprawie dymisji L. Kuczmy. To wreszcie J. Tymoszenko, zwana wówczas „jedynym prawdziwym mężczyzną w ukraińskiej polityce", wystąpiła w lipcu 2001 r. z inicjatywą utworzenia na potrzeby wyborów parlamentarnych 2002 r. bloku wyborczego - Forum Ocalenia Narodowego.

W wyborach do rady Najwyższej Ukrainy w 2002 r. wzięło udział ponad sześćdziesiąt partii politycznych zjednoczonych w trzydziestu blokach. Wybory przyniosły sukces ugrupowaniom opozycyjnym. Najwięcej głosów uzyskały: blok „Nasza Ukraina” W. Juszczenki (23,5\%), Komunistyczna Partia Ukrainy (20\%), blok „O jedną Ukrainę” (blisko 12\%), Socjalistyczna Partia Ukrainy O. Moroza (blisko 9\%) oraz Blok Julii Tymoszenko (7,25\%). W samej Radzie Najwyższej partie i bloki utwo- 
rzyły liczne frakcje. Zwycięstwo zwolenników W. Juszczenki w wyborach nie przełożyło się jednak na możliwość utworzenia przezeń rządu. Walka o większość parlamentarną trwała przez blisko pół roku. Ostatecznie zakończyła się sukcesem sił proprezydenckich, które przeciągnęły na swoja stronę socjalistów i komunistów, tworząc gabinet na czele $\mathrm{z}$ protegowanym R. Achmetowa i klanu donieckiego, premierem W. Janukowyczem. Opozycji pozostało wyciągnięcie lekcji z porażki i przeorganizowanie swej taktyki przed wyborami prezydenckimi, które miały odbyć się za dwa lata.

I tym razem jednak to obóz władzy szybko wybrał swojego kandydata. Był nim stojący na czele Partii Regionów dotychczasowy premier, W. Janukowycz, gwarantujący utrzymanie starego układu. Po stronie opozycji brak było początkowo woli porozumienia w kwestii zjednoczenia sił. Jednak z czasem udało się wyłonić wspólnego kandydata, którym został W. Juszczenko. Z liczących się na scenie politycznej osób wystartowali jeszcze socjalista O. Moroz i komunista Petro Symonenko. Łącznie w pierwszej turze zmierzyło się dwudziestu czterech kandydatów. W kampanii, w obawie o zwycięstwo, obóz władzy chwytał się różnych sposobów, by zapewnić sobie wygraną. Preparowano listy wyborców, utworzono kilkaset okręgów wyborczych w Rosji, demonstracyjnie jawnie przygotowywano struktury siłowe, atakowano fizycznie zwolenników Juszczenki, likwidowano niezależne media. Opozycja obawiała się, że wyniki wyborów będą sfałszowane, na co wskazywały wymienione powyżej nieprawidłowości. Władza posunęła się nawet do próby otrucia W. Juszczenki dioksynami. Tym niemniej to on wygrał 31 października 2004 r. pierwszą turę wyborów. 21 listopada miał zmierzyć się ze zdobywcą drugiego miejsca, W. Janukowyczem.

W dniu drugiej tury przedwyborcze sondaże oraz sondaże exit polls wskazywały jednoznacznie na W. Juszczenkę jako 
zwycięzcę wyborów z przewagą do kilkunastu punktów procentowych. Jednak po zamknięciu lokali wyborczych, jeszcze tego samego dnia, Centralna Komisja Wyborcza podała, że po przeliczeniu ponad 99\% głosów, prowadzi premier W. Janukowycz z kilkuprocentową przewagą nad W. Juszczenką. W tej sytuacji kandydat opozycji zakwestionował uczciwość komisji i wspólnie z J. Tymoszenko wezwał Ukraińców do obywatelskiego nieposłuszeństwa. W odpowiedzi przez dwa dni odbywały się masowe wiece i strajki z hasłami poparcia dla planu powtórzenia głosowania w Kijowie, Lwowie i Doniecku oraz wielu innych ukraińskich miastach. Gdzieniegdzie - jak w stolicy Ukrainy - lokalne władze wsparły żądania opozycji. Apele o powtórzenie wyborów wystosowała również Unia Europejska, opierając się na jednoznacznych opiniach międzynarodowych obserwatorów OBWE, którzy ocenili, że w trakcie głosowania popełniono liczne nadużycia i dokonano manipulacji, a wybory nie spełniały standardów demokratycznych. Jedynym przywódcą na świecie, który pośpieszył z gratulacjami dla W. Janukowycza, był W. Putin.

W tych okolicznościach 23 listopada odbyło się specjalne posiedzenie Rady Najwyższej Ukrainy, która miała ustosunkować się do wyników wyborów, jednak przy braku kworum nie podjęto żadnej decyzji. Również na tym posiedzeniu W. Juszczenko demonstracyjnie, niezależnie od oficjalnych wyników, złożył przysięgę prezydencką, ogłaszając się prezydentem Ukrainy. Znamienne było, że po stronie nowej, nieformalnej głowy państwa zaczęli opowiadać się funkcjonariusze i urzędnicy ukraińskiego Ministerstwa Spraw Wewnętrznych. Jednak następnego dnia Ukraińska Centralna Komisja Wyborcza ogłosiła oficjalnie prezydentem premiera W. Janukowycza, który miał zdobyć ponad 49\% głosów wyborców wobec 46\% uzyskanych przez W. Juszczenkę. W odpowiedzi pryncypialne stanowisko zajęły zgodnie Stany Zjednoczone, Pakt Północnoatlantycki i Unia 
Europejska, nie uznając wyników zmanipulowanych wyborów i żądając ich rewizji.

Dnia 25 listopada na zaproszenie Juszczenki do Kijowa z misją mediacyjną przybył jako laureat Pokojowej Nagrody Nobla Lech Wałęsa; polski Sejm zaapelował do Rady Najwyższej Ukrainy, aby ta zrobiła wszystko dla triumfu prawdy, wolności i demokracji na Ukrainie; opozycja ukraińska zaskarżyła do Sądu Najwyższego rezultaty wyborów prezydenckich, a ten zabronił oficjalnej publikacji wyniku do rozpatrzenia 29 listopada odwołania przeciw Centralnej Komisji Wyborczej. Jednocześnie L. Kuczma poprosił prezydentów Polski - Aleksandra Kwaśniewskiego i Litwy - Valdasa Adamkusa o mediację w sprawie Ukrainy.

Wyjątkowo brzemienny w wydarzenia był kolejny dzień. Do Kijowa przybyli Aleksander Kwaśniewski i szef dyplomacji UE Javier Solana. Z udziałem prezydenta Polski i reprezentanta Unii, a także m.in. prezydenta Litwy, L. Kuczmy, W. Juszczenki, W. Janukowycza i przewodniczącego Dumy Państwowej Rosji, Borysa Gryzłowa rozpoczęły się w stolicy Ukrainy negocjacje w celu rozwiązania politycznego kryzysu nad Dnieprem. $\mathrm{W}$ ich wyniku powstała grupa robocza, która miała rozstrzygnąć konflikt. Równocześnie po stronie opozycji opowiedzieli się otwarcie dziennikarze ukraińskiej telewizji publicznej oraz część wojska i milicji. Z drugiej strony pozycję W. Janukowycza wzmocniły kolejne gratulacje po wygranych wyborach przesłane przez wiernych sojuszników Kremla - prezydentów Uzbekistanu, Kirgistanu, Kazachstanu i Tadżykistanu - oraz deklaracja deputowanych z Doniecka, zawierająca groźbę zorganizowania referendum w sprawie utworzenia autonomicznej republiki, jeśli protesty spowodują unieważnienie wyborczego sukcesu W. Janukowycza.

W dniu 27 listopada parlament w Kijowie przyjął uchwałę głoszącą, że druga tura wyborów prezydenckich odbyła się przy 
masowych naruszeniach ordynacji wyborczej i nie odzwierciedla woli Ukraińców. Na ulicach Kijowa zapanowała radość, którą następnego dnia ostudziły informacje z nadzwyczajnego posiedzenia Ukraińskiej Rady Bezpieczeństwa Narodowego i Obrony, podczas którego L. Kuczma sceptycznie ocenił perspektywy kompromisu pomiędzy władzą i opozycją. W odpowiedzi W. Juszczenko wezwał swych zwolenników do pozostania na Placu Niepodległości w Kijowie - rozsławionego po niespełna dekadzie bohaterstwem uczestników tzw. Euromajdanu - aż do całkowitego zwycięstwa. Natomiast J. Tymoszenko - będąca zwolenniczką radykalnych i spektakularnych działań - zagroziła, że zablokuje ustępującego prezydenta L. Kuczmę w jego własnym domu, jeśli w ciągu dwudziestu czterech godzin nie spełni żądań opozycji, a wśród nich m.in. zwolnienia W. Janukowycza ze stanowiska szefa rządu za sfałszowanie wyników wyborów prezydenckich, zmiany składu Centralnej Komisji Wyborczej, zdymisjonowania gubernatorów wspierających ruchy separatystyczne na wschodzie Ukrainy oraz doprowadzenia do wszczęcia przeciwko nim spraw karnych.

To właśnie tendencje separatystyczne na wschodzie państwa, inspirowane zarówno przez zwolenników W. Janukowycza, jak i Rosję, budziły coraz większy niepokój opozycji. Ich przejawem był przebieg zjazdu przedstawicieli regionów wschodniej Ukrainy w Siewierodoniecku. Ogłosili oni, że uznają za prawowitego prezydenta W. Janukowycza, szantażując groźbą referendum dotyczącego secesji tychże regionów (oprotestowaną solidarnie zarówno przez W. Juszczenkę, jak i L. Kuczmę).

Kluczowy dla przebiegu kryzysu okazał się kolejny tydzień. 29 listopada L. Kuczma i W. Janukowycz opowiedzieli się za ponownym przeprowadzeniem wyborów prezydenckich (ukraińskie prawo wyborcze zabraniało w tym wypadku ubiegania się o prezydenturę tym samym kandydatom). Pomoc w tej sprawie zaoferowała Rada Europy. Jednak W. Juszczenko podtrzymał 
żądanie ponownego rozpisania jedynie drugiej tury wyborów, wzywając równocześnie Sąd Najwyższy - wstrzymujący się dotychczas od orzeczenia - do unieważnienia decyzji Centralnej Komisji Wyborczej, przyznającej zwycięstwo wyborcze W. Janukowyczowi. Argumentu kandydatowi opozycji dostarczył raport pozarządowej organizacji „Otwarta Ukraina”, dotyczący fałszerstw wyborczych podczas drugiej tury wyborów prezydenckich na Ukrainie, według którego sfałszowano ponad trzy miliony głosów na korzyść W. Janukowycza.

Pomimo tych danych, 30 listopada parlament Ukrainy odrzucił wniosek ukraińskiej opozycji w sprawie dymisji rządu, ta w odpowiedzi nie przyjęła propozycji W. Janukowycza, aby przy jego prezydenturze tekę premiera objął W. Juszczenko; podtrzymała sprzeciw wobec pomysłu rozpisania nowych wyborów; zerwała negocjacje z władzami i wznowiła blokadę budynków rządowych w Kijowie. Dzień później w tajnym głosowaniu parlament Ukrainy uchwalił votum nieufności wobec gabinetu W. Janukowycza (którego ten nie uznał), wzywając L. Kuczmę do udzielenia mu dymisji, oraz zaproponował powołanie rządu jedności narodowej.

2 grudnia Parlament Europejski przyjął uchwałę, że wybory prezydenckie na Ukrainie zostały sfałszowane, wzywając do powtórzenia jeszcze w grudniu ich drugiej tury. Zarazem skrytykował prezydenta Rosji za działania, które miały wpłynąć na wynik wyborów na Ukrainie i zapewnić zwycięstwo W. Janukowyczowi. Równocześnie członkowie Centralnej Komisji Wyborczej potwierdzili przed Sądem Najwyższym proceder fałszowania wyników wyborów. Wzmocniony tymi deklaracjami W. Juszczenko zapowiedział, że w przypadku użycia siły przez obóz władzy, opozycja odpowie na to również siłą. Tymczasem L. Kuczma i W. Putin, podczas spotkania w Rosji, skrytykowali postulat powtórzenia drugiej tury wyborów. Równocześnie jednak L. Kuczma zgodził się na dymisję gabine- 
tu W. Janukowycza, o ile wiązałoby się to z reformą ustrojową, przekazującą część kompetencji prezydenckich parlamentowi i rządowi.

3 grudnia ukraiński Sąd Najwyższy podjął ostateczną i nie podlegającą odwołaniu decyzję o powtórzeniu drugiej tury wyborów, ustalając jej termin na 26 grudnia. Postanowienie to spotkało się z entuzjazmem kilkusettysięcznego tłumu zwolenników Juszczenki, zgromadzonego w centrum Kijowa. Dzień później podporządkowała mu się Ukraińska Centralna Komisja Wyborcza.

Decyzja Sądu Najwyższego, uspokajając nieco sytuację i tonując rozgorączkowane nastroje, otworzyła nowy rozdział w dziejach „Pomarańczowej Rewolucji”. 5 grudnia do ofensywy politycznej przeszedł W. Juszczenko. Wezwał do mobilizacji swych zwolenników, konstatując, że walka nie została zakończona. Oświadczył, że grozi mu się śmiercią, a jego najbliższa rodzina zmuszona była zamieszkać w ukryciu, poza Kijowem. Podkreślił również, że do środy parlament musi uchwalić zmiany w ordynacji wyborczej, aby zapewnić uczciwe głosowanie podczas powtórzonej drugiej tury wyborów prezydenckich. Ponownie zaapelował do prezydenta L. Kuczmy o dymisję rządu W. Janukowycza i członków Centralnej Komisji Wyborczej. O tym, iż działania lidera opozycji - zmierzające do podtrzymania czujności jego zwolenników - były uzasadnione, świadczyło fiasko negocjacji z udziałem ukraińskich władz, opozycji i zagranicznych mediatorów, toczących się 6 grudnia. Również wydarzenia kolejnego dnia zdawały się potwierdzać, że droga do ostatecznego sukcesu opozycji jest jeszcze daleka. Co prawda L. Kuczma zwrócił się do parlamentu o odwołanie Centralnej Komisji Wyborczej, która dopuściła do sfałszowania wyników wyborów prezydenckich, jednak do nowej komisji zamierzał powołać kilkunastu członków z jej starego składu. Natomiast W. Janukowycz po raz kolejny odmówił podania się 
do dymisji. W tym wypadku jednak kompromisowo zakończył konflikt L. Kuczma, urlopując go i powierzając pełnienie obowiązków premiera jego zastępcy Mykole Azarowowi.

W odpowiedzi, 8 grudnia, W. Juszczenko ogłosił na kijowskim Placu Niepodległości zwycięstwo „Pomarańczowej Rewolucji”. Równocześnie parlament dokonał nowelizacji konstytucji, przekazując część uprawnień prezydenckich sobie i premierowi. 9 grudnia NATO i, usiłująca ratować twarz oraz wystąpić wraz z Paktem z pozycji mocarstwa zatroskanego o zachowanie standardów demokratycznych, Rosja zaapelowały o wolne i uczciwe wybory na Ukrainie.

Następnego dnia W. Janukowycz potępił dotychczasowe protesty opozycji, a za doprowadzenie do nich obciążył odpowiedzialnością ekipę L. Kuczmy - choć trudno było jednoznacznie zinterpretować, czy za złe ma ustępującemu prezydentowi stworzenie atmosfery przyzwolenia na oszustwa wyborcze, które spowodowały społeczny sprzeciw, czy też brak determinacji w jego tłumieniu. Jednocześnie wezwał kandydata opozycji do udziału w otwartej debacie. Jednak tego samego dnia lider „Pomarańczowej Rewolucji” trafil po raz kolejny do wiedeńskiej kliniki Rudolfinerhaus, w której leczył się wcześniej $\mathrm{z}$ powodu nieustalonej choroby. Tym razem lekarze poinformowali, że jego choroba była spowodowana zatruciem dioksynami (w następstwie tej diagnozy ukraińska prokuratura wznowiła śledztwo w sprawie domniemanego otrucia W. Juszczenki). 12 grudnia przywódca ukraińskiej opozycji powrócił do Kijowa, aby wziąć udział w kampanii prezydenckiej.

Po dwóch tygodniach, 26 grudnia, w powtórzonej drugiej turze zwyciężył W. Juszczenko. Jeszcze w dniu wyborów Centralna Komisja Wyborcza ogłosiła (po przeliczeniu ponad 99\% głosów), iż na kandydata opozycji zagłosowało ponad 52\%, a na W. Janukowycza - 44\% wyborców. 29 grudnia w Kijowie zwolennicy W. Juszczenki zablokowali - na jego wezwanie, 
wynikające z obaw przed możliwością podjęcia przez władze ostatnich, rozpaczliwych prób uniemożliwienia przejęcia przez opozycję urzędu prezydenta - gmach rządu, w którym miało się odbyć posiedzenie gabinetu pod przewodnictwem W. Janukowycza. Ten 31 grudnia w telewizyjnym noworocznym orędziu do narodu ogłosił ustąpienie ze stanowiska szefa rządu. Po przyjęciu dymisji premiera przez ustępującego prezydenta L. Kuczmę, tymczasowym szefem gabinetu został 6 stycznia M. Azarow.

10 stycznia Centralna Komisja Wyborcza poinformowała oficjalnie, że W. Juszczenko zwyciężył w powtórzonej drugiej turze wyborów. Po podliczeniu głosów ze wszystkich obwodowych komisji wyborczych okazało się, że za kandydatem opozycji opowiedziało się ponad 15 milionów Ukraińców (52\% głosów). Natomiast rywala W. Juszczenki poparło blisko 13 milionów wyborców (44\% głosów). Triumfator w tym niecodziennym, wyjątkowo dramatycznym, przedłużonym o miesiąc wyścigu do fotela prezydenta złożył przysięgę prezydencką 23 stycznia $2005 \mathrm{r}$.

„Pomarańczowa Rewolucja” zyskała na świecie przychylność zarówno kierujących się rachunkiem politycznym rządów państw oraz organizacji politycznych i gospodarczych świata demokratycznego - widzących w niej ucieleśnienie hasła walki z dyktaturą, bezprawiem rządzących i imperialnymi ambicjami Rosji - jak i bezinteresowną sympatię demokratycznych społeczeństw i organizacji pozarządowych, traktujących jej uczestników jako bohaterów bezkrwawej walki o triumf idei wolności i praw obywatelskich. Do państw i narodów, które zadeklarowały swoje wsparcie dla „Pomarańczowych” i udzielały go w sposób najbardziej konsekwentny należała Polska i Polacy. Swoje poparcie dla ukraińskiej opozycji obywatele Rzeczypospolitej wyrażali na wiele sposobów. Organizowano marsze solidarności z Ukrainą, koncerty charytatywne w Polsce, występy polskich artystów na Ukrainie, manifestacje za wolność 
i niepodległość na Ukrainie, wiece, pikiety, wspomniane już wyjazdy przedstawicieli polskich władz na Ukrainę w celu prowadzenia negocjacji pomiędzy protestującymi a władzami w Kijowie, rozpowszechnianie ukraińskiej sztuki w Polsce (wystawy, muzyka ukraińska w polskich audycjach radiowych, wydawanie książek wschodnich pisarzy), apele władz miejskich i krajowych wzywające do poparcia „Pomarańczowej Rewolucji”, polskie portale internetowe dotyczące sytuacji na Ukrainie, apele poparcia gazet lokalnych, wreszcie akcje solidarnościowe wśród młodzieży szkolnej i studentów. Natomiast Rzeczpospolita jako państwo wypracowała sobie pozycję swego rodzaju mediatora między Unią Europejską a Ukrainą i dzięki swojemu zaangażowaniu zapewniła Ukrainie unijne wsparcie.

„Pomarańczowa Rewolucja” zapobiegła ewolucji systemu politycznego Ukrainy w kierunku autokratycznym - zachowany został pluralizm polityczny, zwiększył się zakres wolności mediów. Jednocześnie, na skutek braku wymiany elit, nie przeprowadzono rewolucyjnych zmian w funkcjonowaniu państwa ukraińskiego. W następnych latach miało wręcz dojść do pogłębienia symbiozy polityki i wielkiego biznesu, zaniechano reform gospodarczych, nie nastąpił również przełom w procesie zbliżenia Ukrainy do UE. „Pomarańczowa Rewolucja” była jednak nie tylko wyrazem nadziei społeczeństwa na lepsze jutro, w znacznym stopniu przekreślonych przez błędy jej liderów. Stała się dla Ukraińców dowodem, że zdeterminowane społeczeństwo jest w stanie wywrzeć skuteczną presję na rządzących i doprowadzić do przeforsowania swych postulatów, pomimo wsparcia wrogiej mu władzy przez potężnych protektorów z Kremla. 


\section{-ROZ \\ DZIAt \\ IV}

\section{Majdan. Przyczyny - wybuch - co dalej?}

Wiara Ukraińców w to, że nowy prezydent, truty przez politycznych przeciwników i wspierany przez bojowników Pomarańczowej Rewolucji zmieni radykalnie sytuację w kraju okazała się płonna. Jednak kiedy po inauguracji prezydenta - prezydent elekt wszedł wraz z rodziną pomiędzy półmilionowy tłum na Majdanie, owacjom nie było końca. Rozentuzjazmowany tłum skandował „Juszczenko, Juszczenko!” Wydawało się, że zwycięski naród - upojony zwycięstwem nad despotycznym reżimem Kuczmy, nad stworzoną przez niego skorumpowaną strukturą państwa, sięgającą od góry aż po same doły, ze swoim „wywalczonym prezydentem”, przejdzie niczym taran przez trudny czas reform, jakie czekały Ukrainę. Zwycięski naród miał poczucie, że taki sternik wprowadzi Ukrainę na ścieżkę integracji z Zachodem, reformując struktury państwa - od administracji, poprzez policję, wojsko, a kończąc na sądownictwie. Juszczenko wzmacniał wówczas tę wiarę rozmawiając z prostymi ludźmi, nie jak wschodni satrapa, ale jak polityk z Zachodu, wyrażając zainteresowanie ich problemami dnia codziennego. Zwyciężczynią „Pomarańczowej Rewolucji”, 
podówczas niezwykle popularną wśród patriotycznie nastawionej części społeczeństwa ukraińskiego, była też Julia Tymoszenko. Bardzo ambitna i... pragnąca władzy ponad wszystko. Jej prawdziwe oblicze miało ujawnić się dopiero w następnych latach.

Wiktor Juszczenko w swoich publicznych wystąpieniach zapowiedział zwrot w polityce zagranicznej Ukrainy. Podkreślał, że Kijów zrywa z dotychczasową polityką wielowektorową (oznaczającą w praktyce jałowe balansowanie pomiędzy Unią Europejską i Wspólnotą Niepodległych Państw, Stanami Zjednoczonymi i Rosją), a priorytetem ukraińskich władz staje się przystąpienie do Unii Europejskiej oraz - w dalszej perspektywie - do Paktu Północnoatlantyckiego. Równocześnie w swą pierwszą podróż zagraniczną wybrał się do Moskwy, akcentując dobrą wolę współpracy - jednak na równorzędnych, partnerskich warunkach - ze wschodnim sąsiadem. Czytelnym sygnałem ze strony W. Juszczenki, iż przyszłe, poprawne relacje pomiędzy Moskwą i Kijowem muszą być wolne od rosyjskiej ingerencji w wewnętrzne sprawy Ukrainy, a ta ostatnia musi być traktowana przez Kreml jako suwerenny podmiot polityki międzynarodowej, było powołanie J. Tymoszenko - będącej w ocenie rosyjskich władz reprezentantką środowisk najmocniej akcentujących potrzebę ukraińskiej niezależności od Moskwy i zwalczających jej wpływy nad Dnieprem - na premiera nowego gabinetu, który uzyskał poparcie parlamentu w lutym $2005 \mathrm{r}$.

W podróż do Brukseli W. Juszczenko udał się dopiero w trzecim miesiącu urzędowania. Potwierdził tam zwrot Ukrainy w kierunku Unii Europejskiej. Jego wystąpienie w stolicy Unii Europejskiej było potwierdzeniem tezy, że celem Ukrainy jest wstąpienie w struktury europejskie, a w pierwszym rzędzie stanie się członkiem stowarzyszonym, z realną perspektywą wejścia w struktury Unii Europejskiej. Biurokraci z Brukseli byli jednak bardzo ostrożni. Ukraina była gospodarczo ściśle 
powiązana ze Wschodem, a jej struktura wymagała gruntownych reform, które musiały dotknąć boleśnie ukraińskie społeczeństwo, skazane w wyniku ich wdrażania na wiele wyrzeczeń. Blisko 50-milionowy rynek wydawał się co prawda bardzo chłonny, ale jednocześnie był niestety płytki ze względu na powszechną biedę, co zmienić można było dopiero w efekcie wprowadzenia i przeprowadzenia twardej, długofalowej polityki reform. Dlatego też Bruksela opowiedziała na propozycje Wiktora Juszczenki w ostrożny sposób. Wyrażono głębokie zadowolenie z proeuropejskiej polityki, ale zarazem uznano, że Ukraina do integracji z Unią Europejską nie jest jeszcze gotowa. Nie pozostawiono natomiast Ukrainy na pastwę Moskwy. Nie było to bowiem zatrzaśnięcie drzwi, lecz pokazanie zielonego światła, z perspektywą integracji w przypadku podjęcia trudnego wysiłku reformowania państwa. Biurokraci z Brukseli zdawali sobie sprawę, że więcej obiecać nie mogą.

Cieszące się szerokim poparciem społecznym nowe ukraińskie władze, dysponujące niebagatelnymi argumentami personalnymi w postaci uchodzącego za „męczennika demokracji” i niedoszłą ofiarę prorosyjskiego reżimu (wspomniana wcześniej próba otrucia), a także fachowca w dziedzinie ekonomii, W. Juszczenki i charyzmatycznej J. Tymoszenko, szybko i boleśnie zderzyły się z trudną polityczną i gospodarczą ukraińską rzeczywistością.

Zmiana ekipy rządzącej, dokonana w dramatycznych warunkach, pod hasłami walki z korupcją i biedą oraz obrony suwerenności państwa, wzbudziła wielkie społeczne nadzieje. Ukraińcy oczekiwali od „pomarańczowej ekipy” spektakularnego „nowego otwarcia” - szybkich, bezkompromisowych i skutecznych działań w walce z patologiami w życiu ekonomicznym i w administracji, a także wojny ze skorumpowanymi politykami i urzędnikami oraz oligarchicznymi mafiami, pasożytującymi na ukraińskiej gospodarce dzięki nielegalnym 
związkom biznesowo-polityczno-kryminalnym. Należy niestety stwierdzić, iż „pomarańczowe elity” nie sprostały tym wyzwaniom, na co wpływ miały zarówno obiektywne wewnętrzne warunki, w jakich funkcjonowała ukraińska gospodarka oraz swoista ekonomiczna „zimna wojna” prowadzona przeciw uniezależniającej się od wpływów rosyjskich Ukrainie przez Kreml, jak i błędy, zaniechania, a także wewnętrzne konflikty, za które ponosili odpowiedzialność ukraińscy politycy.

23 stycznia 2005 r., podczas inauguracji prezydenckiej, Wiktor Juszczenko ogłosił nadejście polityki czystych rąk i zadeklarował, że jego rząd nie będzie, jak dotychczasowa administracja prezydenta Kuczmy, grabił pieniędzy własnych obywateli. Jednak personalne ruchy W. Juszczenki mówiły o czymś odmiennym. Nominacje prezydenta dowodziły, że znajomości, nepotyzm to jest właśnie balast, którego nie mógł się Juszczenko - liberał z przekonania - pozbyć. Jego znajomy Petro Poroszenko objął funkcję szefa Rady Bezpieczeństwa Narodowego i Obrony, Ołeh Rybaczuk został ministrem do spraw eurointegracji, Jurii Pawłenko ministrem do spraw rodziny, młodzieży i sportu. Natomiast bratanek prezydenta - Jarosław Juszczenko - zastępcą gubernatora w Charkowie. Pomysł Wiktora Juszczenki wzmocnienia roli Sekretariatu Prezydenta, też nie przyczynił się do wzrostu poparcia dla niego, gdyż spowodował zwiększenie napięć w obozie zwycięskich „Pomarańczowych”. Sekretariat Prezydenta stał się drugą siłą w strukturach władzy na Ukrainie. Dublował przy tym kompetencje gabinetu ministrów. Sekretarz administracji prezydenckiej był teraz drugą osobą w państwie. Bez jego decyzji nie można było przeprowadzić żadnej ustawy czy wprowadzić dekretu. Odpowiadał on bezpośrednio przed prezydentem, a Juszczenko sukcesywnie wzmacniał jego urząd. Lawinowo rosły też koszty utrzymania Sekretariatu. Szło to w parze ze wzrostem napięcia z tego powodu pomiędzy „Pomarańczowymi”. 
Wszystko to zaczęło rzutować na postawę społeczeństwa wobec nowej ekipy. Początkowo zdziwienie, a potem spadek poparcia dla W. Juszczenki w społeczeństwie ukraińskim wywołały tarcia, spory i widoczna walka o władzę w obozie zwycięzców. Ukraińcy wybierając Juszczenkę i jego ekipę byli pewni, że stanowią oni silny, zgrany zespół, który przeprowadzi Ukrainę przez konieczną politykę reform. Rozczarowanie spowodowało wzrost niechęci.

Pomimo ostrych sporów w obozie „pomarańczowych”, W. Juszczence z sukcesem udało się zakończyć program „Dziesięciu kroków dla ludzi”. Przede wszystkim udało mu się odwrócić niekorzystną sytuację demograficzną. Dzięki finansowemu wsparciu kobiet, które otrzymały relatywnie duże wypłaty środków finansowym $z$ budżetu za urodzone dzieci (wypłaty te zwiększały się wraz z liczbą dzieci), na Ukrainie nastąpiło demograficzne „odbicie od dna”. Był to wielki sukces prezydenta, a uregulowanie to pozostało trwałym elementem przeobrażeń na Ukrainie, gdyż kolejny prezydent, W. Janukowycz, nie zdecydował się na likwidację tych przepisów. Sukcesem zakończył się także program wsparcia dla ubogich dzieci i wielodzietnych rodzin. Było to jednak połowiczne zwycięstwo, gdyż osiągnięte zostało dzięki wsparciu ukraińskich oligarchów - z najbogatszym Rinatem Achmetowem na czele. Z powodów ekonomicznych nie udało się natomiast zrealizować programu budowy tanich mieszkań dla młodych ukraińskich rodzin wchodzących dopiero na rynek pracy. Obiecujące założenia miała również reforma służby zdrowia. Na jej realizację zabrakło jednak środków w budżecie. Państwa ukraińskiego na tym etapie rozwoju nie było stać na tak kosztowne zmiany.

Pierwsze ostrzegawcze sygnały dla W. Juszczenki i jego obozu pojawiły się już wiosną 2005 r., kiedy to zrealizowane przez rząd nowe wydatki socjalne - skądinąd zrozumiałe w warunkach niskiego poziomu życia szerokich rzesz Ukraińców - spo- 
wodowały zwiększenie inflacji, a w konsekwencji załamanie się wzrostu gospodarczego.

Przekształcenia gospodarcze, godzące w ich interesy, sabotowali ukraińscy oligarchowie, którym rząd Ukrainy nie był w stanie wyznaczyć granic wpływów, oddzielających sferę gospodarki od polityki. W rezultacie oddziaływanie oligarchów na politykę Ukrainy pozostało nadal bardzo silne. W momencie, gdy J. Tymoszenko, jako premier, zdecydowała się na reprywatyzację wielkich zakładów, holdingów, należących do grup finansowych ukraińskich oligarchów Rita Achmetowa i Wiktora Pińczuka, stało to w sprzeczności z ich interesami. Ponieważ byli oni zainteresowani utrzymaniem dotychczasowej linii prywatyzacyjnej, oligarchowie zdecydowali się na konfrontację z rządem J. Tymoszenko, chcąc jej politykę skompromitować sięgając w tym celu po proste narzędzie walki na rynku ukraińskim, czyli stosując zmowę cenową w odniesieniu do wyrobów ropopochodnych i cukru. Ceny tych towarów poszybowały wywołując tzw. kryzysy benzynowy i cukrowy.

Julia Tymoszenko trwała jednak przy swoich koncepcjach, ale choć ceny w wyniku jej działań spadły, władze Ukrainy premier Tymoszenko, prezydent Juszczenko i przewodniczący parlamentu Wołodymir Łytwyn - podpisali memorandum, które gwarantowało nabyte prawa własności i potwierdzało legalność procesów prywatyzacyjnych. Było to poważne ustępstwo wobec ukraińskich oligarchów. Mając wsparcie związanego z wielkim biznesem Petra Poroszenki, na posiedzeniu Rady Bezpieczeństwa Narodowego i Obrony prezydent Juszczenko skrytykował politykę gospodarczą J. Tymoszenko za reprywatyzację i polityczny nacisk wywierany na hurtowników, by obniżali sprzedawaną detalistom cenę benzyny, sztucznie podniesioną w efekcie zmowy cenowej oligarchów. Konflikt w obozie „pomarańczowych” zaogniał się. Oligarchowie zaś wychodzili z prób ograniczenia ich wpływów na rynku zwycięsko. 
Rozczarowanie w społeczeństwie budziło także „żółwie tempo" wyjaśniania i rozliczania przestępstw (zabójstw politycznych i malwersacji), popełnionych przez przedstawicieli dawnego reżimu: sprawy dziennikarza Gongadze czy próby otrucia samego W. Juszczenki. Równocześnie, co podkreślało wielu obseratorów i uczestników życia politycznego na Ukrainie, w obozie „pomarańczowych” pojawiły się niepokojące i nasilające się z czasem symptomy „choroby władzy”. Triumfatorzy „Rewolucji 2004 roku” uwierzyli w to, że właśnie oni - nie zaś protestujący po II turze wyborów zwykli Ukraińcy, odrzucający patologie poprzedniego politycznego układu, byli autorami owego sukcesu. Zaczęli powielać błędy i gorszące opinię publiczną działania obozu L. Kuczmy i W. Janukowycza, na czele z aktami nepotyzmu i korupcji, odrzucając zarazem rzeczową krytykę, jako wynikającą rzekomo jedynie z wrogości politycznej, niedoinformowania lub będącą zwykłym kłamstwem. Do obniżenia popularności nowej władzy w społeczeństwie przyczyniały się, paradoksalnie, również jej sukcesy - wprowadzona po zwycięstwie „Pomarańczowej Rewolucji” i przestrzegana nad Dnieprem autentyczna wolność słowa i swoboda mediów skutkowały podejmowaniem przez środki masowego przekazu krytyki rządzących, skutecznie tłumionej w minionym okresie.

Prawdziwym "gwoździem do trumny” władzy „pomarańczowego" obozu była jednak jego wewnętrzna niespójność i skłonność do sporów, wynikająca zarówno z ambicji personalnych jego przywódców, rozbieżności programowych, jak i zgubnego przeświadczenia, że dla ówczesnych rządów nie stanowią realnego zagrożenia prorosyjskie i oligarchiczne środowiska, skupione wokół L. Kuczmy i byłego rywala W. Juszczenki w wyborach prezydenckich, a skompromitowane ponoć ostatecznie w oczach społeczeństwa rządami sprawowanymi przed 2004 r. Już wiosną zarysowały się zatem konflikty między najbliższymi współpracownikami prezydenta - pre- 
mier J. Tymoszenko, sekretarzem Rady Bezpieczeństwa Narodowego i Obrony Petrem Poroszenką oraz sekretarzem stanu Ołeksandrem Zinczenką, a także generalny spór o pozycję rzeczywistego lidera nowego obozu władzy i o program polityczny pomiędzy „ludową”, pozującą często na trybuna „zwykłych Ukraińców”, J. Tymoszenko a liberałem W. Juszczenką. W ich wyniku najpierw zostali zdymisjonowani O. Zinczenko i P. Poroszenko, a następnie sama „piękna Julia”, po której obowiązki premiera miał przejąć Jurij Jechanurow. Ta ostatnia kandydatura została jednak odrzucona w parlamencie przez Blok J. Tymoszenko.

Wojna w obozie „pomarańczowych” przyczyniła się także do utraty przez nich wizerunku niezłomnych, ideowych i pryncypialnych przeciwników reżimu L. Kuczmy i W. Janukowycza. Aby bowiem zapewnić swemu kandydatowi na premiera poparcie parlamentarne, W. Juszczenko przyjął ofertę pomocy ze strony W. Janukowycza. Lider Partii Regionów w zamian za poparcie swego ugrupowania dla Jechanurowa wymógł na W. Juszczence zgodę na układ polityczny, który był zaprzeczeniem idei „Pomarańczowej Rewolucji”, stanowiący m.in., że odpowiedzialni za fałszerstwa wyborcze w 2004 r. zostana objęci amnestią.

Tymczasem kryzys gospodarczy na Ukrainie i rozdźwięki wśród „pomarańczowych” pogłębił coraz bardziej widoczny kryzys gazowy. Po objęciu władzy przez W. Juszczenkę, w którym Rosja widziała przeciwnika koncepcji rozciągnięcia i utrwalenia wpływów Kremla nad Dnieprem, relacje na linii Kijów-Moskwa uległy wyraźnemu oziębieniu. Wynikało ono z polityki szantażu Putina, którą stosował on zresztą wobec wszystkich państw dawnego ZSRS. Z Ukrainą Gazprom rozpoczął negocjacje już w marcu 2005 r. informując, że cena gazu zostanie urynkowiona do poziomu europejskich cen. Kreml podwyższył cenę gazu z 50 do 160 dolarów za 1000 metrów 
sześciennych i naciskał na podpisanie nowej umowy. Ukraina nie zgodziła się na zakup gazu od Gazpromu po wyższych cenach, w reakcji na te propozycje Naftohaz Ukrainy podwyższył cenę za tranzyt do 1,60-2 dolarów z 1 dolara 9 centów za 1000 metrów na stu kilometrach przesyłu. Gazprom chciał, by Ukraina płaciła 160 dolarów za 1000 metrów sześciennych, a Rosja za przesył 1,6o dolara. Było to bardzo niekorzystne dla Ukrainy, gdyż Rosja płaciła na Słowacji, w Czechach i Niemczech wyższe stawki za przesył. Spowodowało to kryzys i jednostronną podwyżkę ceny przez Moskwę do 230 dolarów, co sprawiło, że delegacja ukraińska, w odpowiedzi na kremlowski szantaż, zerwała negocjacje w Moskwie 31 grudnia 2005 r. Putin nakazał zdominowanym już przez jego propagandę rosyjskim mediom, prasie i telewizji, rozpoczęcie kreowania wizerunku Ukrainy jako winnej zerwania negocjacji gazowych. Wszystko to odbywało się w trakcie srogiej zimy. Rosjanie doskonale wiedzieli, kiedy ich szantaż może wywrzeć pozytywny skutek. Brak porozumienia 1 stycznia 2006 r. spowodował, że Gazprom rozpoczął zmniejszanie ciśnienia w rurociągu, zresztą jeszcze przed upływem rosyjskiego ultimatum, upływającego o godz. 10:0o czasu miejscowego. Ostatecznie 4 stycznia podpisano wstępne porozumienie i dostawy zostały wznowione. Ukraina przegrała konfrontację z Rosją Putina. Rząd Jurija Jechanurowa podpisał porozumienie, że Ukraina w pierwszym kwartale będzie płacić po 95 dolarów za 1000 metrów sześciennych, a potem już po cenie podyktowanej przez Putina, czyli 230 dolarów za 1000 metrów sześciennych.

Konsekwencją kryzysu gazowego był impas w strategicznych dla Ukrainy negocjacjach gazowych, dotyczących cen gazu sprzedawanego jej przez Rosję. Ostatecznie Rosjanie oskarżyli Kijów o kradzież gazu, ograniczyli jego dostawy, a następnie przerwali je od stycznia 2006 r. Działanie to podyktowane było przy tym nie tyle ekonomicznym dążeniem do 
zwiększenia rosyjskich zysków ze sprzedaży gazu, ile przede wszystkim polityczną motywacją zdyskredytowania „pomarańczowych” władz w oczach ukraińskiego społeczeństwa i zwiększenia szans na zwycięstwo prorosyjskiej Partii Regionów w przyszłych wyborach parlamentarnych. Stanowiło zatem przykład brutalnej, znamiennej dla polityki zagranicznej Kremla (nie tylko wobec Ukrainy), ingerencji w wewnętrzne sprawy innych państw.

W marcowych wyborach parlamentarnych $2006 \mathrm{r}$. i podczas prowadzonych po ich przeprowadzeniu negocjacji - mających wyłonić parlamentarną większość i w konsekwencji nowy gabinet - osłabiony wewnetrznymi konfliktami i porażkami ponoszonymi w polityce społecznej i gospodarczej obóz „pomarańczowych” poniósł porażkę, ustępując miejsca rozgrywającej bezbłędnie sytuację, zwycięskiej Partii Regionów W. Janukowycza. Wobec jej sukcesu w wyborach i fiasku rozmów prowadzonych przez „pomarańczowych” (chcących doprowadzić do ponownego objęcia urzędu premiera przez J. Tymoszenko), w sierpniu 2006 r. prezydent zmuszony był desygnować na premiera swego byłego rywala w wyborach prezydenckich. Kandydatura ta została poparta przez nową parlamentarną większość.

Wraz z umacnianiem się pozycji nowego rządu zaczęły narastać jego konflikty z głową państwa. Ukraina weszła w okres przedłużającego się, permanentnego politycznego kryzysu. Rok 2007 przyniósł przedterminowe wybory parlamentarne, będące wynikiem dekretu W. Juszczenki, rozwiązującego parlament stanowiący oparcie dla gabinetu W. Janukowycza. „Nowe rozdanie” potwierdziło jednak tylko silną pozycję Partii Regionów, która ponownie zdobyła największą liczbę mandatów. Jednak fotel premiera objęła J. Tymoszenko, dzięki porozumieniu ugrupowań, wywodzących się z obozu „Pomarańczowej Rewolucji”. Paradoksalnie, nie zakończyło to 
walki politycznej pomiędzy prezydentem i premierem - tyle tylko, iż konflikt o władzę narastał teraz ponownie pomiędzy przywódcami „pomarańczowych” - W. Juszczenką i „Piękną Julią”. Nowa premier już w rok później zaczęła krytykować prezydenta za blokowanie antyinflacyjnych inicjatyw rządu, a ten rewanżował się jej oskarżeniami o zdradę interesów państwowych i działanie na rzecz Rosji. W tych warunkach doszło do kolejnego flirtu cześci „pomarańczowych” - tym razem skupionych wokół J. Tymoszenko - z Partią Regionów, który zaowocował przegłosowaniem przez parlament zmian prawnych, ograniczających uprawnienia prezydenta.

W warunkach rozbicia „pomarańczowego" obozu w wyborach prezydenckich, w styczniu 2010 r. zwyciężył „niezatapialny” W. Janukowycz, pokonując w drugiej turze J. Tymoszenko (dotychczasowy prezydent przepadł w pierwszej turze, uzyskując około 6\% głosów). Dwa miesiące później parlament ukraiński wyraził wotum nieufności dla rządu, a następnie zatwierdził nowy gabinet, na którego czele stanął przewodniczący Partii Regionów i zausznik W. Janukowycza, Mykoła Azarow.

Nowy obóz władzy przystapił szybko do bezwzględnej politycznej vendetty, której główną ofiarą miała stać się była premier, mająca - w odróżnieniu od W. Juszczenki, drugiego wielkiego rywala W. Janukowycza - wciąż silną pozycję polityczną na Ukrainie. Wszczęto przeciwko niej postępowania karne związane z zarzutami defraudacji, a w 2011 r. aresztowano ją, osądzono, skazano na karę siedmiu lat pozbawienia wolności i osadzono w kolonii karnej w Charkowie. Budzące liczne watpliwości prawne postępowania karne, wytaczane J. Tymoszenko, zostały ostro skrytykowane przez Parlament Europejski. W kwietniu 2013 r. Europejski Trybunał Praw Człowieka w przedmiocie skargi Julii Tymoszenko przeciwko Ukrainie orzekł m.in., że jej tymczasowe aresztowanie było bezprawne i nieuzasadnione. Tymczasem w październiku $2011 \mathrm{r}$. wszczęto postępowanie w spra- 
wie udziału J. Tymoszenko w zabójstwie posła i przedsiębiorcy Jewhena Szczerbania, do którego doszło w 1996 r. W styczniu 2013 r. przedstawiono jej zarzut zlecenia dokonania tej zbrodni, po czym postępowanie zawieszono $\mathrm{z}$ uwagi na brak dowodów co do udziału byłej premier w przestępstwie.

Równolegle z polityczną wojną prowadzoną przez W. Janukowycza i jego obóz z przeciwnikami, przeciwstawiającymi się dyktatorskim działaniom prezydenta w sferze polityki wewnętrznej - krępowaniu swobody słowa, bezprawnym represjom wobec opozycji, postępującej oligarchizacji życia gospodarczego (odbywającej się pod osłoną i za przyzwoleniem rządzących), wreszcie czysto kryminalnym, przestępczym poczynaniom i powiązaniom przedstawicieli nowej władzy a zarazem uzależnianiu polityki zagranicznej Ukrainy i jej gospodarki od rosyjskiego protektora Partii Regionów i samego W. Janukowycza, postępował proces faktycznego demontażu i zawłaszczania poszczególnych podmiotów i całych sektorów ukraińskiej gospodarki przez obóz rządzący, pogarszania się sytuacji materialnej społeczeństwa, a także wasalizacji Kijowa przez Moskwę na arenie międzynarodowej. Coraz bardziej widoczne symptomy tych zjawisk generowały społeczne niezadowolenie, które miało znaleźć ujście u schyłku 2013 r. w wielkiej spontanicznej rewolcie na Majdanie.

Rządy Wiktora Janukowycza to na Ukrainie okres wzmagającego się chaosu. Po wygranych w 2010 r. wyborach przeniósł on zachowania z Donbasu na cały kraj. Korupcja, wyniesienie osób pozbawionych jakichkolwiek kwalifikacji - ale będących zwolennikami jego i Partii Regionów - na wysokie stanowiska, stały się normą. „Desantem” ludzi z Donbasu zaczęto obsadzać wszelkie stanowiska. Łamanie prawa przez ludzi W. Janukowycza stało się rzeczą nagminną. Ukraińskie firmy zmuszano do płacenia haraczu. Legalne funkcjonowanie firm w czasach nowego prezydenta było niemożliwe. Po zorganizowaniu Mi- 
strzostw Europy w Piłce Nożnej (UEFA Euro 2012) okazało się, że gospodarka ukraińska traci dynamikę, sztucznie nakręconą przez budowę infrastruktury niezbędnej do przeprowadzenia w Ukrainie czternastego turnieju o mistrzostwo Europy w piłce nożnej. Działania rządu firmowanego przez W. Janukowycza spowodowały, że Ukraina osiągnęła stan bliski niewypłacalności, połączony ze spadkiem wartości papierów dłużnych, które osiągnęły tzw. wartość śmieciową. Koszty takich działań ponosiło społeczeństwo Ukrainy. Rosły ceny, przy jednoczesnym spadku siły nabywczej ukraińskiej hrywny. Korupcja sięgnęła wszystkich dziedzin życia.

Szło to w parze $z$ antyeuropejskim kursem realizowanym przez Janukowycza. Dwustronna umowa o stacjonowaniu Floty Czarnomorskiej Federacji Rosyjskiej na Krymie, podpisana w Charkowie w 2010 r., wywołała na Ukrainie oburzenie. Sytuacja uległa jeszcze zaognieniu w 2013 r. Ruch popierający przetrzymywaną w więzieniu od sierpnia 2011 r. Tymoszenko rósł w siłę. Janukowycz zaczął tracić poparcie nawet w regionach, gdzie dotychczas dominującą pozycję miała jego partia - Partia Regionów. Kolejnym jego ruchem było popisanie umowy na dostawy gazu, w której to za rezygnację ze zbliżenia z Europą Ukraina otrzymała zniżkę. Katastrofalna sytuacja gospodarcza państwa spowodowała, że na Ukrainie realne stało się wstrzymanie poborów w instytucjach państwowych. Janukowycz nie miał szans na jakiekolwiek kredyty $z$ Zachodu. W rezultacie wielomiliardowego kredytu miała Ukrainie udzielić Rosja Putina, która dążyła na bazie zwiększania zależności Ukrainy i innych państw regionu do powołania Unii Euroazjatyckiej, czyli odbudowy imperium.

Swoistym zapalnikiem wybuchu okazała się kwestia podpisania przez Ukrainę umowy stowarzyszeniowej z Unią Europejską, zaplanowana podczas szczytu Partnerstwa Wschodniego w Wilnie jeszcze w marcu 2012 r. Tymczasem w listopadzie 
2013 r. zmajoryzowany przez zwolenników W. Janukowycza parlament ogłosił wstrzymanie negocjacji stowarzyszeniowych z powodu pogarszającej się sytuacji ekonomicznej państwa, wynikającej ze spadku poziomu produkcji i wymiany handlowej z krajami Wspólnoty Niepodległych Państw. Prezydent zadeklarował przy tym, że umowa co prawda nie zostanie podpisana z powodu problemów finansowych i gospodarczych, lecz negocjacje w jej sprawie zostaną wznowione, jeśli UE zdecyduje się skompensować ewentualne straty z niej wynikające (których przyczyną byłyby m.in. ekonomiczne represje ze strony Kremla wobec emancypującego sie spod jego wpływów Kijowa). W ślad za tą deklaracją 21 listopada 2013 r. W. Janukowycz odłożył podpisanie umowy stowarzyszeniowej z Unią Europejską.

Decyzja ta przelała czarę goryczy i zaktywizowała Ukraińców. Zapoczątkowała ona protesty zwolenników integracji z Unią Europejską. Ukraińcy wyszli na ulice. Majdan w Kijowie stał się faktem. Protesty objęły nie tylko Kijów, ale wiele miast na Zachodniej Ukrainie. Entuzjazm ludzi, z różnych warstw społecznych, był ogromny. Uczestnicy Majdanu zdawali sobie sprawę z powagi sytuacji, ale nie wiedzieli jeszcze wówczas, że jest to ruch, który odegra tak dużą rolę w dziejach Ukrainy i Europy.

Już 24 listopada w Kijowie ponad stutysięczny tłum demonstrował za integracją Ukrainy z Unią Europejską. Ukraińcy sprzeciwiali się temu, co czyni z krajem wybrany przez prorosyjski wschód Janukowycz. Oburzenie łączyło ludzi z szerokich kręgów społecznych, od robotników poprzez intelektualistów, aż po biznesmenów. Przeciwko manifestantom władze skierowały milicję, która użyła gazu łzawiącego. Podobna sytuacja powtórzyła się w naddnieprzańskiej stolicy pięć dni później. $\mathrm{Na}$ Placu Niepodległości w Kijowie zaczęli koczować protestujący 
przeciwko polityce rządu. Równocześnie kilkudziesięciotysięczny studencki wiec odbył się we Lwowie.

Represje władz okazały się nieskuteczne - gdy 30 listopada specjalne oddziały milicji Berkut brutalnie spacyfikowały czuwających na Placu Niepodległości, używając pałek i gazu łzawiącego, już następnego dnia zebrało się tam ponowanie kilkaset tysięcy osób. Doszło do gwałtownych starć pomiędzy demonstrantami i milicją, a część protestujących przystąpiła wręcz do szturmu na budynki rady miasta Kijowa. Wobec determinacji zwolenników proeuropejskiej polityki Ukrainy 4 grudnia władze usiłowały zastosować wobec nich swoiście pojmowaną metodę „kija i marchewki” - Ministerstwo Spraw Wewnętrznych wydało policji zakaz używania siły wobec manifestantów, a zarazem Prokuratura Generalna kategorycznie nakazała im natychmiastowe opuszczenie budynków rządowych. Cztery dni później potężna, kilkusettysięczna antyrządowa demonstracja w Kijowie zakończyła się symbolicznym obaleniem pomnika Lenina, będącego dla opozycji tyleż znienawidzonym symbolem komunizmu, co uzależnienia Ukrainy od wschodniego sąsiada. Reakcją ze strony obozu rządzącego było wszczęcie śledztwa w sprawie próby nielegalnego przejęcia siłą władzy w państwie i akcja zdecydowanego usuwania demonstrantów z okolic budynków rządowych przez milicję i służbę bezpieczeństwa. Jednocześnie prezydent zgodził się na organizację ukraińskiego „okrągłego stołu”, przy którym mieliby zasiąść przedstawiciele władzy i opozycji w celu rozwiazania kryzysowej sytuacji.

Położenie stawało się jednak coraz bardziej dramatyczne. Na Ukrainie zjawiła się co prawda 10 grudnia szefowa dyplomacji UE Catherine Ashton, która spotkała się z W. Janukowyczem oraz - na kijowskim Placu Niepodległości - z uczestnikami antyrządowych protestów. Prezydenta przekonywała usilnie do pokojowego rozwiązania konfliktu, natomiast manifestan- 
tów zapewniła o pełnej gotowości Unii Europejskiej do podjęcia przerwanych rozmów stowarzyszeniowych. Gdy wydawało się, że pojawiła sie szansa chociażby na wystudzenie nastrojów, 11 grudnia w nocy Berkut i wojska wewnętrzne MSW rozpoczęły regularny szturm na zapełniony ludźmi kijowski Majdan. Atak ten ostatecznie nie powiódł się i milicja wycofała się z centrum stolicy. Następnego dnia C. Ashton oświadczyła, że prezydent Ukrainy zamierza docelowo podpisać porozumienie w sprawie stowarzyszenia z UE. Jednak wobec braku odzewu ze strony Kijowa, 15 grudnia Unia oficjalnie zawiesiła wszelkie rozmowy z Ukrainą w sprawie podpisania umowy stowarzyszeniowej. W odpowiedzi ponownie setki tysięcy Ukraińców protestowało na Majdanie domagając sie już nie tylko podpisania porozumienia, ale i dymisji rządu. Na tle tej masowej manifestacji dość groteskowo wyglądał zorganizowany przez władze w stolicy kilkutysięczny „spontaniczny” prorządowy wiec zwolenników Partii Regionów.

Pomimo nasilających się protestów W. Janukowycz wyjechał do Rosji i 17 grudnia spotkał się w Moskwie z prezydentem Rosji Władimirem Putinem. Podpisano wówczas porozumienie w sprawie zniesienia ograniczeń handlowych między obydwoma krajami, które przeciwnicy prorosyjskiej polityki na Ukrainie interpretowali jednoznacznie jako następny krok w kierunku ścisłego powiązania gospodarek obu państw i tworzenia faktów dokonanych, mających utrudnić ewentualną integrację z Europą. Dnia 22 grudnia na Placu Niepodległości nadal trwały wielotysięczne protesty, podczas których ogłoszono powstanie ponadpartyjnego ruchu społecznego o nazwie „Ogólnonarodowe Zjednoczenie Majdan”. Trzy dni później okupujących Plac zelektryzowała informacja o pobiciu przez „nieznanych sprawców" ukraińskiej aktywistki i dziennikarki Tetiany Czornowoł. Z kolei 16 stycznia 2014 r. ukraiński parlament przyjął tzw. ustawy dyktatorskie, umożliwiające ograniczenie wolności słowa 
i zgromadzeń i zaostrzenie odpowiedzialność karnej za udział w „nielegalnych” demonstracjach. Przegłosowanie tych ustaw uznane przez „majdanowców” za prowokację ze strony władz i dowód ich arogancji - wzmogło tylko falę protestów. Tydzień później paść miały pierwsze ofiary - 22 stycznia opozycja podała informację, że podczas zamieszek w Kijowie zginęło pięć osób. Równocześnie odnaleziony został uprowadzony wcześniej przez „nieznanych sprawców” jeden z liderów kijowskiego Majdanu, Dmytro Bułatow. Porywacze bili go i brutalnie torturowali. Sam D. Bułatow co prawda deklarował, że nie ma pewności, kto stał za uprowadzeniem, ale stwierdził, że sprawcy rozmawiali z rosyjskim akcentem. Tego samego dnia W. Janukowycz zaproponował liderom opozycji, Arsenijowi Jaceniukowi (kierującemu „Batkiwszczyną” - partią uwięzionej J. Tymoszenko) i Witalijowi Kliczce (byłej gwieździe światowego boksu, a zarazem przywódcy ugrupowania „Udar”) odpowiednio stanowisko premiera i wicepremiera ministra do spraw nauki - teki w istocie niewiele znaczące w prezydenckim systemie panującym na Ukrainie i przy dominacji w parlamencie Partii Regionów. Propozycje te - odrzucone przez adresatów jako posunięcie oszukańcze, służące jedynie ich pacyfikacji - protestujący na Majdanie i opozycja trafnie interpretowali jako próbę rozbicia jedności antyrządowego frontu.

Tymczasem rozruchy rozszerzały się na inne miasta i regiony Ukrainy. We Lwowie deputowani rady obwodowej utworzyli Radę Narodową, będącą w istocie pozakonstytucyjnym organem „ludowym”, która uchwaliła bezwzględny zakaz dla nadzwyczajnych działań ukraińskich sił zbrojnych i specjalnych formacji Ministerstwa Spraw Wewnętrznych na terenie obwodu lwowskiego. Pod koniec stycznia, dość niespodziewanie dla ekspertów i obserwatorów sytuacji politycznej na Ukrainie, podkreślających - skądinąd słusznie - silne tendencje i sentymenty prorosyjskie na wschodnich kresach państwa, zamiesz- 
kiwanych w dużym stopniu przez ludność napływową z Rosji, ruch sprzeciwu wobec władz objął również i te obszary.

W związku z nadzwyczajną sytuacją, 28 stycznia parlament ukraiński zebrał się na specjalnym posiedzeniu. Do dymisji podał się premier M. Azarow. Prezydent przyjął jego rezygnację, polecając mu jednocześnie pełnienie dalej swej funkcji do czasu powołania nowego rządu. Natomiast parlament anulował przyjęte zaledwie szesnaście dni wcześniej „ustawy dyktatorskie”. Następnego zaś dnia rozpoczął przygotowywanie ustawy o amnestii dla uczestników demonstracji. W trakcie prac nad nią ostry spór po raz kolejny podzielił opozycję i rządzącą koalicję, której przewodziła Partia Regionów. Opozycja żądała amnestii bezwarunkowej, Partia Regionów zaś była temu przeciwna, uzależniając „akt łaski” od natychmiastowego opuszczenia przez demonstrantów zajmowanych przez nich budynków rządowych (zarówno w samym Kijowie, jak i w stolicach obwodów). Wieczorem parlament przegłosował ostatecznie projekt amnestii w kształcie zgłoszonym przez obóz rządzący. Tego samego dnia na kijowskim Placu Niepodległości powołana została Gwardia Narodowa, w skład której weszła m.in. dotychczasowa Samoobrona Majdanu i narodowo-radykalny Prawy Sektor.

Kolejny kryzys przyniosły wydarzenia z połowy lutego. W parlamencie 18 lutego deputowani opozycji zablokowali trybunę parlamentu, domagając się włączenia do porządku obrad głosowania nad przywróceniem konstytucji z roku 2004, która ograniczyłaby uprawnienia prezydenta W. Janukowycza (co oznaczałoby wprowadzenie na Ukrainie systemu parlamentarno-prezydenckiego). Równocześnie demonstranci z Majdanu rozpoczęli potężny marsz na parlament (tzw. Pokojowy Atak), który został ostatecznie skutecznie zablokowany przez Berkut. Manifestanci zamierzali otoczyć siedzibę ukraińskiej legislatywy i powstrzymać przed jej opuszczeniem deputowanych 
Partii Regionu, dopóki nie spełnią oni żądań opozycji. Przypuszczono szturm na pozycje milicji ochraniającej budynek parlamentu.

Walki pod parlamentem doprowadziły do gwałtownej radykalizacji nastrojów. Gwałtowne starcia pomiędzy manifestantami i milicją wybuchły w Parku Maryjskim, leżącym naprzeciwko gmachu. Demonstranci zajęli również ponownie opuszczony kilka dni wcześniej kijowski ratusz oraz biuro rządzącej Partii Regionów. Krwawe starcia trwały na ulicach Instytuckiej i Hruszewskiego w okolicach Majdanu. Media podały, że podczas walk zginęło pięciu demonstrantów, a stu pięćdziesięciu odniosło rany. Dramatyzm sytuacji pogłębiał fakt, iż w rejon walk Berkut nie dopuszczał służb medycznych i pomocy poszkodowanym udzielać musieli członkowie tzw. Automajdanu, czyli wolontariusze, wykorzystujący swe prywatne samochody do zaopatrywania demonstrantów w żywność, odzież, środki sanitarne i leki. Po wybuchu starć W. Kliczko zaapelował do W. Janukowycza o usunięcie z ulic oddziałów milicji, sił wojskowych MSW i Berkutu. Natomiast MSW wezwało liderów opozycji, by uspokoili protestujących i powrócili do rozmów z władzami.

W godzinach popołudniowych siły rządowe kolejny raz podeszły pod Majdan, a opozycji przedstawiono ultimatum żądając, by demonstranci opuścili barykady. Jednak ci nadal montowali wzmocnienia, szykując się do obrony placu. Zebrało się na nim wówczas około dwudziestu tysięcy ludzi. W stolicy władze wstrzymały ruch metra, by uniemożliwić ochotnikom dotarcie na Majdan. Na samym placu siły rządowe zaczęły polewać demonstrantów wodą z armatek, z kolei protestujący odpalali fajerwerki, rzucali petardy i koktajle Mołotowa, miotali kostkę brukową, ścierali się z atakującymi milicjantami w walce wręcz, uzbrojeni w prowizoryczne tarcze, kije, sztaby i metalowe drągi. Następnie na tłum zaczęły nacierać transportery opancerzone, 
rozpoczynając właściwy szturm na Majdan. Pod naporem Berkutu i wykorzystywanego przeciwko protestujacym ciężkiego sprzętu bojowego padła barykada na ulicy Instytuckiej. Równocześnie berkutowcy rozpoczęli od strony niedalekiego Placu Europejskiego dwugodzinny szturm, który - pomimo zażartego oporu manifestantów - spowodował zepchnięcie tłumu z części Majdanu. Po stronie rządowej do walki zostali wprowadzeni komandosi i snajperzy oraz kryminaliści („tituszki”), terroryzujący cywilów. Od północy z 18 na 19 lutego Kijów stał się praktycznie miastem zamkniętym. Na Majdanie spłonął budynek związków zawodowych, wykorzystywany przez demonstrantów jako siedziba. Równocześnie „majdanowcy” odgrodzili się od Berkutu stosami płonących opon i wznoszonymi barykadami.

Doszło wreszcie do spotkania liderów ukraińskiej opozycji z prezydentem W. Janukowyczem. Prezydent kategorycznie odmówił przerwania szturmu i zażądał natychmiastowej ewakuacji Placu Niepodległości. Rano 19 lutego tyraliery Berkutu ruszyły ponownie do akcji, spychając „majdanowców” na środek placu. W trakcie tych ciężkich walk śmierć poniosło ponad trzydzieści osób - przede wszystkim spośród bojowników.

Tego samego dnia we Lwowie opozycjoniści zajęli szturmem podpalony wcześniej budynek administracyjny jednostki Wojsk Wewnętrznych. Również w Tarnopolu i Iwano-Frankowsku nastąpiły udane szturmy na siedziby władz obwodowych. Dzień później manifestanci w Równem zajęli siedzibę Berkutu. W godzinach porannych 19 lutego, Rada Narodowa we Lwowie przejęła pełnię władzy w obwodzie lwowskim, wypowiadając tym samym posłuszeństwo władzy centralnej w Kijowie, a miejscowe organy administracji państwowej oraz milicja podporządkowały się powołanej przez lwowskich deputowanych kilka tygodni wcześniej Radzie Narodowej. Zadeklarowano udzielenie pomocy dla demonstrantów w Kijowie. Gdy 
z Dniepropietrowska ruszyła na Kijów 25. Brygada Powietrznodesantowa, rzekomo aby wzmocnić „ochronę baz wojskowych i arsenałów”, została zablokowana przez solidaryzujących się z walczącymi na Majdanie, zdeterminowanych cywilów.

Krwawe wydarzenia na kijowskim Placu Niepodległości oraz kryzys polityczny na całej Ukrainie, która stanęła na krawędzi wojny domowej, przyciągnęły uwagę świata. W związku z zastosowaniem przez prorosyjski reżim W. Janukowycza brutalnej przemocy wobec własnych obywateli, Stany Zjednoczone nałożyły sankcje wizowe na odpowiedzialnych za ten fakt ukraińskich prominentów. Szef Komisji Europejskiej, José Manuel Durão Barroso potępił w rozmowie telefonicznej z W. Janukowyczem użycie siły przeciwko demonstrantom. Ostro i solidarnie wypowiadali się na temat przelewu krwi na Ukrainie polscy politycy wszystkich obozów, a także przedstawiciele rządu i prezydenta. Rząd Litwy zdecydował, że 20 lutego będzie dniem żałoby narodowej. Minister spraw zagranicznych Szwecji, Carl Bildt, stwierdził, że ukraiński prezydent „ma krew na rękach”. Z kolei Rosja wydarzenia w Kijowie nazwała próbą zamachu stanu, oskarżając o nią dość egzotyczną koalicję miejscowych „skorumpowanych polityków”, „żądnych władzy oligarchów”, „faszystów” i „nazistów”, aktywistów LGBT(!) oraz - w nieoficjalnych komentarzach części polityków - nawet... ukraińskich Żydów. W wystąpieniach rosyjskich polityków i w koncesjonowanych przez Kreml mediach zaczął również pojawiać się wątek międzynarodowego spisku - inspirowania i wspierania antyrządowego protestu przez Amerykanów, Unię Europejską, państwa nadbałtyckie oraz „tradycyjnie rusofobiczną" Polskę.

Tymczasem nadzieję na zaprzestanie rozlewu krwi dało kolejne spotkanie liderów opozycji z W. Janukowyczem, zakończone porozumieniem w sprawie rozejmu na Majdanie oraz inicjatywa Wysokiego Przedstawiciela UE do Spraw Zagra- 
nicznych, C. Ashton, która zwróciła się z prośbą do ministrów spraw zagranicznych Polski, Niemiec i Francji - Radosława Sikorskiego, Franka-Waltera Steinmeiera i Laurenta Fabiusa o udanie się ze specjalną misją dyplomatyczną do Kijowa. Jednak już 20 lutego rozejm został zerwany, wskutek podpalenia przez milicjantów budynku konserwatorium muzycznego, zajętego przez opozycję. Efektem tego był ponowny wybuch gwałtownych starć. Demonstranci odbili część Majdanu, a następnie pomimo ostrzału ze strony snajperów ruszyli za wycofującymi się berkutowcami, zajmując kolejne gmachy i wznosząc barykady. Ewakuowany został wówczas parlament.

W tych warunkach 20 lutego odbywały się spotkania unijnych mediatorów z W. Janukowyczem, reprezentującym Kreml rosyjskim rzecznikiem praw obywatelskich Władimirem Łukinem i reprezentantami opozycji. Równocześnie Unia Europejska zdecydowała się wprowadzić pakiet sankcji personalnych i ogólnych, zawierających zakazy wizowe i zamrożenie aktywów zagranicznych oraz zakaz handlu bronią z Ukrainą. Przełom w negocjacjach nastąpił 21 lutego. Zawarto wówczas porozumienie dotyczące ograniczenia praw prezydenta do tych, które określała konstytucja z 2004 r., sformowania nowego rządu i przeprowadzenia wcześniejszych wyborów prezydenckich w grudniu 2014 r. Ustalenia te - początkowo odrzucone przez tzw. Radę Społeczną Majdanu - zostały ostatecznie zaakceptowane przez protestujących.

Tego samego dnia w parlamencie opozycja domagała się dymisji W. Janukowycza. Przegłosowano też zwolnienie z odpowiedzialności karnej uczestników trwających antyrządowych protestów i uwolnienie J. Tymoszenko. Gdy zapadały te decyzje do Kijowa docierały informacje krzepiące protestujących - na stronę demonstrantów przechodziły kolejne grupy i całe garnizony funkcjonariuszy sił rządowych (z obwodu lwowskiego do stolicy przyjechały autobusy wypełnione milicjantami, popie- 
rającymi „majdanowców”), a w miastach na Ukrainie masowo obalano pomniki Lenina.

Reakcje zagranicy, ale także samych Ukraińców, na informacje o porozumieniu były dwoiste. $\mathrm{Z}$ zadowoleniem wiadomość tę przyjęły Stany Zjednoczone, organy UE i wiekszość państw europejskich. Z chóru wspierajacego porozumienie wyłamał się jedynie Kreml, który deklarował co prawda poparcie dla decyzji o przerwaniu walk, ale podkreślał, że kijowskie wydarzenia noszą znamiona zamachu stanu. Charakterystyczne, iż równocześnie „Sbierbank” - największy bank Rosji i całej Europy Wschodniej - zawiesił udzielanie kredytów na Ukrainie, a Rosja wstrzymała zakup ukraińskich obligacji. Z kolei wśród „majdanowców”, obok większości akceptującej - choć bez entuzjazmu - wynegocjowane porozumienie, byli i tacy (rekrutujący się przede wszystkim z narodowo-radykalnego Prawego Sektora), którzy domagali się pod groźbą kontynuowania walki natychmiastowej dymisji W. Janukowycza.

Ten jednak jeszcze wieczorem 21 lutego wyleciał do Charkowa. Stamtąd trafił do Doniecka, gdzie ukraińska straż graniczna uniemożliwiła jego wylot do Moskwy z powodu braku koniecznych dokumentów. Dwa dni później W. Janukowycz dotarł na Krym, skąd podjał następną - jak się później okazało tym razem udaną - próbę ucieczki pod skrzydła swego rosyjskiego protektora. Tymczasem na Ukrainie rozesłano za nim list gończy i wszczęto śledztwo w sprawie jego odpowiedzialności za masowe zabójstwa cywilnych obywateli (25 lutego parlamentarzyści przyjęli rezolucję o odpowiedzialności Janukowycza za śmierć ponad stu cywilów i opowiedzieli się za postawieniem go przed Międzynarodowym Trybunałem Karnym). Dopiero 28 lutego W. Janukowycz zdradził miejsce swego nowego pobytu, uczestnicząc w konferencji prasowej w rosyjskim Rostowie, podczas której stwierdził, że nadal uwa- 
ża się za prezydenta Ukrainy, a jego odsunięcie od władzy było nielegalne.

22 lutego W. Kliczko zaapelował do parlamentu o uchwalenie rezolucji wzywającej Janukowycza do ustąpienia oraz namawiał do przeprowadzenia wyborów prezydenckich do 25 maja 2014 r. Parlament wybrał nowego przewodniczącego, którym został deputowany opozycyjnej partii „Batkiwszczyna” Ołeksandr Turczynow; podjął uchwałę potępiającą tendencje separatystyczne i wzywającą do ochrony niepodzielności terytorialnej Ukrainy; wprowadził też w życie uchwałę mówiącą o ograniczeniu kompetencji prezydenta; przyjął rezolucję o uwolnieniu J. Tymoszenko, a przede wszystkim - zadecydował o odsunięciu od władzy prezydenta W. Janukowycza, który miał w sposób niekonstytucyjny wycofać się sam z wykonywania swych uprawnień, nie podpisując żadnego z nowych aktów prawnych parlamentu. Deputowani zdecydowali też, że wcześniejsze wybory prezydenckie odbędą się 25 maja.

Następnego dnia O. Turczynow został wybrany na stanowisko pełniącego obowiązki prezydenta i wygłosił orędzie do narodu, w którym zapowiedział powrót Ukrainy na drogę integracji europejskiej i budowanie stosunków z Rosją na zasadach dobrosąsiedzkich. 24 lutego parlament nadał wszystkim poległym „majdanowcom” tytuł Bohatera Ukrainy.

W ekspresowym tempie powołano też nowy rząd. Już 26 lutego w dość niecodziennych jak na ustrój demokracji pośredniej okolicznościach - niecodzienne były jednak także warunki - nie w parlamencie, lecz na Majdanie, ogłoszono zgromadzonym tłumnie Ukraińcom, uczestnikom protestów i „Kijowskiego Powstania” kandydaturę Arsenija Jaceniuka na stanowisko premiera oraz zaprezentowano skład jego gabinetu. Wicepremierami mieli zostać Borys Tarasiuk oraz Olha Bohomołeć. Tekę ministra spraw zagranicznych zdecydowano się powierzyć Andrijowi Deszczycy, ministra młodzieży i spor- 
tu - D. Bułatowowi, ministra spraw wewnętrznych - Arsenowi Awakowowi, szefa Rady Bezpieczeństwa - dotychczasowemu Komendantowi Majdanu, Andrijowi Parubijowi. Akceptacja kandydatur odbyła się poprzez aklamację kilkudziesięciu tysięcy zgromadzonych obywateli.

Dopiero po tym wydarzeniu - w którym jedni obserwatorzy wydarzeń na Ukrainie chcieli widzieć nawet powrót do demokracji bezpośredniej, zakorzenionej w świecie antycznym; inni z patosem wskazywali na jego prasłowiańskie, „wiecowe” źródła; pozostali sięgali natomiast z jednej strony do utrwalonego w ukraińskiej świadomości archetypu kozackiego sposobu obradowania, z drugiej do specyfiki „pomajdanowej” sytuacji, w której przeświadczeniu, że to „lud, nie politycy wywalczył zwycięstwo" towarzyszyła powszechna, choć stopniowana, nieufność wobec całego świata politycznego (także wobec opozycji, która jako obóz rządzący zawiodła po „Pomarańczowej Rewolucji”) - wydarzenia przeniosły się do parlamentu. Nazajutrz na jego forum O. Turczynow (przewodniczący legislatywy, pełniący zarazem obowiązki prezydenta Ukrainy) poinformował o ukonstytuowaniu się nowej, większościowej koalicji parlamentarnej. Ogłosił też, że wysunęła ona na funkcję premiera A. Jaceniuka. Po jego zaakceptowaniu przez deputowanych nastąpiło zatwierdzenie gabinetu, firmowanego przez nowego prezesa Rady Ministrów, wcześniej popartego przez Majdan. Jednym z pierwszych posunięć nowego rządu - traktowanym powszechnie jako realizacja postulatów, w imię których protestowano przeciwko reżimowi W. Janukowycza na Majdanie - było podpisanie 21 marca części politycznej umowy stowarzyszeniowej z Unią Europejską.

Triumf proeuropejskiego Majdanu i obalenie reżimu Janukowycza, oznaczające przyjęcie przez Ukrainę kursu na pełną niepodległość, zerwanie z pozycją państwa zależnego w istocie od Moskwy i zwycięstwo koncepcji integracji z Europą, było 
jednak - jak się okazało - dopiero początkiem trudnej, dramatycznej, krwawej i pełnej wyrzeczeń walki o utrzymanie suwerenności i terytorium państwa.

Hasło do antyukraińskiej rewolty dał Krym. Większość mieszkańców stanowią tam Rosjanie, a w granicach sowieckiej Ukrainy znalazł się on decyzją czerwonego Kremla dopiero po II wojnie światowej. Region ten, jak już wspomniano, od początku niepodległości Ukrainy cieszył się zarówno formalną, jak i faktyczną autonomią. Gdy więc doszło do zmiany reżimu i odsunięcia od władzy popularnych na Krymie Partii Regionów i samego prezydenta W. Janukowycza, mieszkańcy półwyspu rozpoczęli akcje protestacyjne przeciwko nowej władzy w Kijowie oraz manifestacje, deklarując przyjaźń z Rosją. Usiłowali przeciwstawiać się im miejscowi Ukraińcy i lojalni wobec państwa ukraińskiego Tatarzy krymscy. Sytuacja przybrała nieoczekiwany obrót w końcu miesiąca - 27 lutego uzbrojeni ludzie zajęli w Symferopolu budynki parlamentu i rządu Republiki Autonomicznej Krymu, po czym wywiesili flagę rosyjską, a krymska legislatywa przegłosowała referendum dotyczące statusu Krymu. Dzień później rosyjscy żołnierze opanowali wojskowe lotnisko Belbek w Sewastopolu i lotnisko w Symferopolu. Kreml zaczął przerzucać na Krym rosyjskie wojska, zajmować kolejne ukraińskie bazy wojskowe i przejmować kontrolę nad półwyspem, czemu nie byli w stanie przeciwstawić się ustępujący agresorowi militarnie Ukraińcy. Następnie połączone zgromadzenie Rady Najwyższej Republiki Autonomicznej Krymu i Rady Miejskiej Sewastopola przyjęło deklarację niepodległości Republiki Krymu, a 16 marca odbyło się referendum dotyczące statusu półwyspu. Za przyłączeniem Krymu z Sewastopolem do Rosji zagłosowało według rebeliantów i Kremla około 95\% uczestników przy frekwencji bliskiej 85\%. W związku z tym 17 marca Rada Najwyższa Republiki Autonomicznej Krymu przyjęła postanowienie o jego niepodległości, 
a suwerenność republiki jeszcze tego samego dnia uznała Rosja. Nazajutrz podpisano umowę między Rosją a Republiką Krymu i miastem wydzielonym Sewastopolem o włączeniu Krymu do Rosji jako nowych podmiotów rosyjskiej federacji.

W czasie niepokojów na Krymie wiece przeciwko nowym władzom w Kijowie zorganizowano również we wschodnich obwodach Ukrainy - w Charkowie, Dniepropietrowsku, Doniecku, Chersoniu, Odessie i Mikołajowie. Prorosyjscy demonstranci wdzierali się się do budynków regionalnej administracji, opanowywali je, wywieszali rosyjskie flagi i zdzierali ukraińskie. Zwolennicy niezależności od Kijowa organizowali również improwizowane plebiscyty w sprawie utworzenia ze wschodnich regionów Ukrainy - w ramach planu „federalizacji” państwa tzw. Noworosji. Odbywały się wiece, starcia z niezdecydowanie interweniującymi służbami, bójki z prorządowymi grupami, manifestacje poparcia dla Kremla. Podczas starć w Doniecku 13 marca i w Charkowie dzień później padły ofiary śmiertelne, zarówno po stronie prorządowych, jak i prorosyjskich demonstrantów. W rozruchach, obok zamieszkujących na Ukrainie sympatyków utrzymania silnych związków z Moskwą, brali udział również masowo przybysze $\mathrm{z}$ Rosji. W związku z tym na Ukrainie wprowadzono nakaz wiz dla obywateli tego państwa, by ograniczyć napływ Rosjan uczestniczących w manifestacjach w miastach wschodniej Ukrainy. Ponadto, trafnie odczytując, iż rozruchy mogą stanowić wstęp do próby secesji wschodnich regionów, wspieranej militarnie przez Moskwę, Ukraina postawiła swoje siły zbrojne w stan pełnej gotowości bojowej. Działania separatystyczne na wschodniej Ukrainie były nie tylko inspirowane, ale i wspierane na arenie międzynarodowej przez ekipę rządzącą na Kremlu. Propagandzie rosyjskiej, nakierowanej na ukazanie światowej opinii publicznej nowych władz Ukrainy jako grupy uzurpatorów, która doszła do władzy w wyniku zbrojnego nacjonalistyczno-faszystowskiego przewrotu, towarzyszyły 
działania moskiewskiej dyplomacji, usiłującej wywierać presję na ukraińskie władze, a zarazem wpływać na nastawienie politycznych elit i społeczeństw świata zachodniego. Kiedy 24 marca minister spraw zagranicznych Rosji Siergiej Ławrow spotkał się w Hadze z ministrem spraw zagranicznych Ukrainy, Andrijem Deszczycą, jednoznacznie nastawał na przyjęcie przez Kijów jako obowiązującej w polityce wewnętrznej koncepcji federalizacji Ukrainy. Przyznać trzeba, że odpowiedź Kijowa była celna: premier Ukrainy Arsenij Jaceniuk zasugerował w zamian, by język ukraiński stał się drugim językiem urzędowym w Rosji oraz by Rosja zmieniła ustrój na konfederacyjny.

W kwietniu 2014 r. separatystyczne wystąpienia na wschodzie Ukrainy przerodziły się w konfrontację militarną między ukraińskimi wojskami i siłami bezpieczeństwa a separatystami prorosyjskimi, wspieranymi przez oddziały regularnej rosyjskiej armii i dostawy broni z Rosji - pomimo kłamliwych zaprzeczeń Kremla, że jest stroną w konflikcie. Po faktycznym opanowaniu bądź zablokowaniu przez separatystów siedzib władz państwowych i samorządowych, gmachów administracji, milicji, sił bezpieczeństwa oraz baz wojskowych do akcji wkroczyły - celem przywrócenia porządku konstytucyjnego - wojska ukraińskie, które zostały zaatakowane przez rebeliantów. W trakcie walk zwolennicy secesji wschodniej Ukrainy proklamowali suwerenność samozwańczych „republik”: donieckiej (6 kwietnia) i ługańskiej (27 kwietnia). W obydwu 11 maja zorganizowano referenda dotyczące ich statusu, w których ich obywatele opowiedzieli się, według wyników zaprezentowanych przez separatystów, za niezależnością i inkorporacją w skład Federacji Rosyjskiej. W efekcie, 24 maja w Doniecku, podczas zjazdu partii Noworosja powołano Federacyjną Republikę Noworosji. Ogłoszono, że stolicą samozwańczego państwa zostanie Donieck. Oficjalnym językiem został język rosyjski, a religią „państwową” - Rosyjski Kościół Prawosławny. 
Tymczasem krwawe wydarzenia objęły swym zasięgiem również Odessę, gdzie najpierw pochód sympatyków Majdanu został zaatakowany przez tzw. antymajdanowców, następnie przeciwnicy nowych władz Ukrainy - których atak został odparty przez uczestników proeuropejskiego pochodu - zabarykadowali się w miejscowej siedzibie związków zawodowych. W trakcie walk, w których obydwie strony używały koktajli Mołotowa, gmach spłonął, a w starciach i w pożarze zginęło blisko pięćdziesiąt osób.

Obecnie konflikt na wschodniej Ukrainie trwa. Nazwy miast, takich jak Donieck, Słowiańsk czy Mariupol zapisały się na trwałe w historii jako miejsca zaciekłych walk pomiędzy broniącymi niepodległości i inegralności terytorialnej państwa wojskami ukraińskimi i siłami rebelianckimi wspieranymi przez wojska rosyjskie. Zaangażowanie Moskwy w wojnę zaowocowało z jednej strony - w obliczu miażdżącej przewagi napastnika - utratą przez Kijów kontroli nad wschodnimi kresami państwa i wzrostem nastrojów nacjonalistycznych i imperialnych w Rosji, z drugiej nałożeniem przez świat zachodni, przede wszystkim Stany Zjednoczone, Kanadę i Unię Europejską, gospodarczych i personalnych sankcji na agresora.

W cieniu wojny 25 maja odbyły się na Ukrainie wybory prezydenckie, w których zwyciężył przedsiębiorca i polityk Petro Poroszenko. Już 20 czerwca przedstawił on scenariusz działań, mających na celu znalezienie politycznego rozstrzygnięcia konfliktu ukraińskiego. Jego plan pokojowy opierał się na jednostronnym zawieszeniu broni przez armię ukraińską, w czasie którego separatyści mieliby się rozbroić i opuścić okupowane ziemie i budynki administracji państwowej; ogłoszeniu amnestii dla tych, którzy złożą broń, a nie dopuścili się ciężkich przestępstw; wreszcie utworzeniu zdemilitaryzowanej strefy buforowej pomiędzy obszarem kontrolowanym przez separatystów i państwo ukraińskie. 
Sytuacja na Ukrainie, Majdan, bezprawna agresja żołnierzy Putina na Krymie, były wynikiem działań Putina, któremu Zachód pozwolił na taką politykę wobec państw dawnego ZSRS. Rok 2008 i agresja na Gruzję, a przede wszystkim reakcja Zachodu na poczynania Putina na Kaukazie oznaczały zielone światło dla jego planów odbudowy imperium. Rosjanie w wojnie z Gruzją zmusili 230 tysięcy Gruzinów do ucieczki z Osetii Południowej. Do dzisiaj mieszkają w prowizorycznie postawionych domach, jako uchodźcy, wzdłuż gruzińskiej drogi wojennej, kilkanaście kilometrów od Tbilisi. Wspólnota Niepodległych Państw, funkcjonująca pod auspicjami Kremla, podpisany w roku 1992 traktat taszkiencki, będący układem o bezpieczeństwie zbiorowym, wsparcie Armenii w walkach o Nagorny Karabach - wszystko to pokazało prawdziwe oblicze Rosji i jej zaangażowanie w odbudowę swojej dawnej pozycji.

Putin wykorzystuje przewagę militarną wobec próbujących zachować niezależność państw powstałych po rozpadzie ZSRR. Robił to już po utracie wpływów Rosji na Kaukazie w latach dziewięćdziesiątych XX w. Wówczas USA i Unia Europejska zainteresowały się Azerbejdżanem, bogatym w zasoby ropy naftowej i gazu ziemnego. $\mathrm{W}$ rezultacie Azerbejdżan, Gruzja i Uzbekistan nie odnowiły podpisanego w 1992 r. traktatu taszkienckiego, który przekształcił się w 2002 r. w Organizację Układu o Bezpieczeństwie Zbiorowym, układu zbiorowego bezpieczeństwa niektórych państw Wspólnoty Niepodległych Państw pod egidą Moskwy. Z inicjatywy byłego prezydenta Gruzji Eduarda Szewardnadze, Azerbejdżan wraz z Gruzją, Mołdawią i Ukrainą stworzył wymierzoną w dominację rosyjską w regionie Organizację na rzecz Demokracji i Rozwoju (GUAM). Moskwa tymczasem realizuje swoją politykę, tworząc łańcuch zależnych państw 
bądź oderwanych enklaw, podporządkowanych Kremlowi, które tworzyłyby satelicki łańcuch od Azji Środkowej po Europę Południową. Ukraina miała być bardzo ważnym elementem odbudowy tego łańcucha zależnych państw. Dlatego Rosja wsparła separatystów z Abchazji, a Abchaska Republika Autonomiczna jest de facto jej satelitą. Kolejne satelity Moskwy - Naddniestrze (Naddniestrzańska Republika Mołdawska), Górski Karabach i Osetia Południowa są elementami rosyjskiej polityki. Bardzo istotne dla Putina w tej polityce odbudowy imperium są Kazachstan, Armenia i Euroazjatycka Unia Gospodarcza.

Ukraina za rządów Janukowycza miała stać się trwałym elementem Euroazjatyckiej Wspólnoty Gospodarczej. Polityka, jaką stosuje Putin wobec tego państwa jest przemyślana. Krym ma być ostoją rosyjskiej floty czarnomorskiej i dla baz rosyjskich eskadr lotnictwa. Zabór Krymu ma zdecydować o powrocie Rosji Putina nad Morze Czarne. Putin, stosując politykę faktów dokonanych, zdaje sobie sprawę ze słabości Unii Europejskiej, podziału Unii na Starą i Nową, i z interesów gospodarczych, które rozbijają jej jedność. Rosja przekształcona za jego rządów w państwo surowcowe zmusza mocarstwa zachodnie do retoryki zimnowojennej, jednak Putin i jego doradcy zdają sobie doskonale sprawę z interesów i potrzeb surowcowych Europy, a co za tym idzie z braku wsparcia dla memorandum budapeszteńskiego. Słabość Zachodu jest atutem Rosji.

Równocześnie trzeba podkreślić, że kryzys 2008 r. odcisnął piętno na gospodarce Unii Europejskiej. Poważnym problemem dla UE jest fakt, że główną gałąź gospodarki wspólnoty stanowią usługi (telekomunikacyjnje, bankowe, budowlane, transportowe - w tym samochodowe, morskie, lotnicze), a dopiero w dalszej kolejności przemysł i rolnictwo. W rezultacie najważniejszym czynnikiem napędzającym wzrost jest nie eks- 
port, a popyt wewnętrzny. Przy wysokich wydatkach sztywnych, stopień redystrybucji dochodów jest stosunkowo wysoki (w Szwecji dochodzi np. do 6o\% PKB) i choć nie hamuje efektywnego funkcjonowania gospodarki, to jednak nie stymuluje szybkiego i innowacyjnego rozwoju. Pasywność Unii Europejskiej w okresie agresji Putina na Krym i wojny w rejonie donieckim i ługańskim to duże wyzwanie dla struktur europejskich. Egzaminu nie zdała najsilniejsza gospodarka eurolandu, czyli Niemcy - zarazem polityczny lider UE, zmierzający do koordynowania wschodniej polityki Wspólnoty w okresie kryzysu ukraińskiego.

Unia Europejska musi zdecydować się na głębokie reformy strukturalne zarówno gospodarcze, jak i polityczne. Szansą dla niej jest podpisanie Transatlantyckiego Partnerstwa Handlowego i Inwestycyjnego, zakładającego wyeliminowanie ceł, barier administracyjnych i regulacyjnych, które utrudniają handel i inwestycje pomiędzy Unią Europejską a USA. Otworzy to dotychczas chronioną sztucznymi barierami gospodarkę UE, co musi spowodować wzrost konkurencyjności tak w przemyśle, jak i dotowanym, nisko uprzemysłowionym i mało konkurencyjnym wobec rolnictwa USA - rolnictwie UE. Z drugiej strony pozwoli na uniezależnienie się UE od dostaw surowców, gazu i ropy, z Rosji stosującej wieloletni i kosztowny dla UE dyktat surowcowy. W dobie postępującej globalizacji tylko zniesienie sztucznych barier gospodarczych w kontaktach euroatlantyckich pozwoli na budowę nowoczesnej, innowacyjnej, silnej gospodarki, która będzie mogła przeciwstawić się potędze gospodarczej państw azjatyckich - Chin i Indii. Taka strategia może przyśpieszyć również integrację gospodarczą z Ukrainą. Jednocześnie może stać się zaczątkiem reformy politycznej UE, która uczyni ją silniejszą, eliminując słabość okazaną przez Unię Europejską wiosną 2014 r., w czasie bezprecedensowej w historii powojennej Eu- 
ropy agresji Rosji na terytorium Ukrainy. Dla Unii Europejskiej większym wyzwaniem jest Ukraina niż Grecja. Wsparciem dla Unii Europejskiej są przy tym niskie ceny surowców, unormowanie sytuacji handlowej pomiędzy nią a Iranem, co powinno jeszcze zbić ceny surowców i uderzyć w osłabioną sankcjami gospodarkę Rosji, dla której coraz większym obciążeniem finansowym będzie prowadzenie wojny na południu Ukrainy i utrzymanie Krymu.

Z jednej strony o przyszłości Ukrainy zdecyduje determinacja nowych władz i narodu ukraińskiego do utrzymania krwawo wywalczonej niepodległości; silne ambicje integracji z Unią Europejską i coraz mocniej akcentowane aspiracje znalezienia się w szeregach Paktu Północnoatlatyckiego; zapowiedzi gruntownego zreformowania i zracjonalizowania funkcjonowania ukraińskiej gospodarki i walki z dotychczasowymi patologiami życia gospodarczego; deklaracje i działania pomocowe ze strony Stanów Zjednoczonych i UE (zarówno polityczne, jak i ekonomiczne); deklarowana solidarność Zachodu z Kijowem w konflikcie na wschodzie państwa, który jest już w istocie mniej lub bardziej zakamuflowaną wojną z Rosją. Z drugiej strony ubóstwo społeczne; wyrzeczenia, jakie będą wiązały się z procesem reformowania gospodarki; rozgoryczenie stratami terytorialnymi; nieufność „ludu” wobec ukraińskich elit politycznych; presja polityczna i ekonomiczna ze strony Rosji; rozbieżność narodowych i państwowych interesów oraz stosunku do Moskwy wśród krajów deklaratywnie wspierających Ukrainę.

Te szanse i zagrożenia, awers i rewers dzisiejszej ukraińskiej codzienności oraz narodowo-społecznych ambicji, nastrojów i lęków nie tylko nad Dnieprem, ale także w Europie, w Rosji i za oceanem sprawiają, że trudno wyrokować o dalszych losach tego wielkiego, historycznego sąsiada Rzeczypospolitej. Warto jednak pamiętać, że część odpowiedzialności 
za realizację pozytywnego dla Ukrainy scenariusza umocnienia jej niepodległości, przywrócenia integralności terytorialnej i zrealizowania planu integracji z Zachodem ponosi również Polska, a przede wszystkim jej elity polityczne. I to nie w imię pięknego skądinąd sentymentu, lecz w imię racjonalnie pojętej - właśnie wbrew resentymentom - racji stanu Rzeczypospolitej oraz idei bezpieczeństwa i stabilności regionu, dla którego zagrożeniem są rosyjskie ambicje imperialne. 


\section{MÓJ \\ MAJ \\ DAN \\ relacja Swietłany Krawczenko z płonących barykad Kijowa}

\section{Jak to się zaczęło}

Euromajdan w Kijowie, a tak nazywali go ludzie od pierwszych dni protestów, nie uformował się przypadkowo. Wbrew intensywnej rosyjskiej propagandzie, która do dzisiaj twierdzi, że Majdan był wynikiem działania zachodnich służb specjalnych, protesty w Kijowie i innych miastach Ukrainy były logicznym skutkiem działalności ówczesnej ukraińskiej władzy. W latach 2010-2013, kiedy prezydentem był W. Janukowycz, odczuwałam, podobnie jak wszyscy przeciętni Ukraińcy, że na naszych szyjach powoli zaciska się śmiertelna pętla. Partia Regionów na czele z prezydentem i w szczególności jego rodzina otwarcie przywłaszczały sobie najbardziej dochodowe przedsiębiorstwa państwowe oraz należące wcześniej do innych właścicieli, koncentrując w swoich rękach ogromne pieniądze. Władza nawet nie bardzo starała się ukrywać podporządkowywania interesów Ukrainy Rosji, przekształcając stopniowo państwo w rosyjską kolonię. W zakresie kultury przypuszczono totalny atak na wszystko, co ukraińskie. We wszystkie obszary życia społecznego wprowadzany był język rosyjski. Tytuły Bohaterów Ukrainy nadawano rosyjskim gwiazdom popu. Z podręczników historii usuwano rozdziały o ruchu narodowo- 
-wyzwoleńczym. Nie było środków na ukraińskie kino, teatr czy wydawnictwa książkowe.

Panowało poczucie uciemiężenia. Powszechne było odczucie całkowitego upadku rozsądku i totalnej beznadziei. Wielu chciało coś zmienić, ale żaden człowiek sam nic nie mógł uczynić. W latach prezydentury Janukowycza wciąż dochodziło do protestów. Na ulice wychodzili przedsiębiorcy, demonstrując sprzeciw wobec ordynacji podatkowej; studenci i intelektualiści, negujący nową ustawę o językach; nawet kibice piłkarscy niezadowoleni z niesprawiedliwego sędziowania; wreszcie mieszkańcy wsi Wradijiwka z obwodu Mikołajewskiego, tyranizowani przez milicję. Zazwyczaj protestowało od kilkuset do kilku tysięcy ludzi. O fakcie narastania w społeczeństwie tak się przejawiającej frustracji wciąż pisali i mówili socjologowie. Od jednego procenta gotowych wyjść na ulice w 2013 r. liczba potencjalnych uczestników protestów szybko wzrosła do pięciu procent.

Władza była o tym informowana, lecz z powodu degeneracji moralnej i intelektualnej oraz zadufania we własne siły dostrzegała ona tylko swoje interesy. Co tam jacyś maluczcy, nikczemni, niezadowoleni Ukraińcy? Dlatego przyjęcie przez rząd decyzji o zahamowaniu postępu integracji europejskiej stało się - w zaistniałej sytuacji publicznej - ostatnią kroplą, która przelała czarę goryczy i cierpliwości. Innej drogi Ukraińcy po prostu nie mieli.

Występował jeszcze inny czynnik, który niewątpliwie również był istotny. Był to duch wolności. Gdyż, czego by nie powiedzieć o trzecim prezydencie Ukrainy, Wiktorze Juszczence, o zdradzonych hasłach Pomarańczowej Rewolucji itd., to właśnie on dał Ukraińcom wolność słowa. Janukowycz zaś jeszcze nie zdążył jej w całości odebrać i wolność myśli w tym okresie na Ukrainie miała o wiele szerszy zasięg, aniżeli w Rosji czy na Białorusi. Na przykład, nie zważając na to, że wszyscy rektorzy uczelni na Ukrainie (nie mówiąc już o państwowych urzędni- 
kach) przymusowo stawali się członkami rządzącej Partii Regionów i musieli wysławiać Janukowycza - zgodnie z sowieckimi tradycjami - nie bałam się swoim studentom mówić prawdy i prezentować własnej opinii o tym, co dzieje się w państwie: o rusyfikacji naszej kultury, monopolizacji gospodarki i przekształcaniu demokratycznej władzy w dyktaturę. Po prostu nie można było uwierzyć, iż na współczesnej Ukrainie można karać za wolne myśli. To wykraczało poza zdolność pojmowania.

Doświadczenie Pomarańczowej Rewolucji pozostawiło pozytywne skutki. Wiara, że kiedy „Razom nas bahato, nas ne podołaty” („Razem jest nas wielu, więc nas nie pokonacie” - hasło Pomarańczowej Rewolucji), pozostała. Byłam pewna: jeśli wyjdzie na ulice bardzo dużo osób - Janukowycz będzie skazany na ich wysłuchanie. Okazało się, że takich jak ja są dziesiątki i setki tysięcy...

Pierwsi protestujący wyszli na Plac Niepodległości w Kijowie wieczorem 21 listopada 2013 r. po ogłoszeniu decyzji rządu o wstrzymaniu eurointegracji. To byli społecznicy, studenci, dziennikarze, opozycyjni politycy. Wtedy na ulice, na wiece dla wyrażenia protestu, wyszli ludzie także w innych trzynastu miastach Ukrainy. Dziennikarze piszą, że właśnie tego dnia zrodziło się hasło „Ukraina - to Europa!” Ludzie w Kijowie i na całej Ukrainie wychodzili na ulice codziennie aż do 28-29 listopada, do wileńskiego szczytu. Domagali się od prezydenta, aby ich wysłuchał i podpisał umowę o zbliżeniu z Unią Europejską. Liczba uczestników protestów nieustannie rosła. W ciągu tego pełnego napięć tygodnia władza zaczęła kierować do obiegu informacji na Ukrainie rozmaite wyssane z palca wiadomości o ekonomicznych stratach Ukrainy po związaniu się z UE, o braku korzyści z eurointegracji i przeróżne inne bzdury. Na tle masowych akcji protestacyjnych były one tak nikczemne, jak sama władza, która to czyniła.

Jednak większość Ukraińców spodziewała się, że prezydent, którego wybrał naród, w końcu posłucha jego głosu. Spodzie- 
wałam się tego i ja. Nie mogłam uwierzyć, by prezydent mógł aż tak lekceważyć swój naród. Myślałam, że kiedy miliony osób sprzeciwiają się, to on powinien ich wysłuchać. Jakże inaczej? Jednak zapewne Janukowycz rozumiał, że protestuje akurat ta część Ukraińców, która go nie wybierała.

Po kilku dniach, mimo zakazu sądu, zaczęto stawiać „samowolne zabudowania” na Placu Niepodległości i na pobliskich ulicach. Przed 7 stycznia 2014 r. pojawiło się namiotowe miasteczko, które miało przetrwać aż do zakończenia szczytu w Wilnie. Codziennie podczas wieców dochodziło w różnych miejscach do starć z milicją i berkutowcami. Atmosfera stawała się coraz bardziej napięta. Do protestów dołączyło w tym czasie bardzo dużo młodzieży - głównie studenci, którzy w końcu listopada stali się napędową siłą protestów.

Wyniki szczytu stały się zapewne największym rozczarowaniem Ukraińców w ciągu ostatnich lat. Nie można było uwierzyć, że Janukowycz naprawdę całkowicie zignorował opinię swojego narodu. Chciało się płakać, szlochać, bo stawało jasne, że przygotowują nam nową „sowiecką” przyszłość w „braterskim” związku z Rosją. Rozpacz rozrywała serce. Było oczywiste, że ani dla mnie, ani dla moich dzieci w tej przyszłości nic dobrego się nie wydarzy. Koniec ze wszystkim! Tylko rozpacz z powodu nieodwracalności sytuacji mogła właściwie coś zmienić...

Następnego dnia rano, kiedy zobaczyłam w telewizji (a można to było zobaczyć tylko na kanałach 5. i 24.), jak berkutowcy w nocy rozpędzali resztki protestujących na Placu Niepodległości - przede wszystkim młodzież i studentów - to było już całkiem inne uczucie. To był gniew i nienawiść. Obrazy bezbronnych młodych ludzi, których - leżących - bito pałkami i kopano, ciągnięto ociekających krwią do milicyjnych samochodów, zszokowały Ukrainę. Komuś udało się uciec z Placu do Soboru Michajłowskiego, gdzie go ukryto i udzielono mu pomocy... Potem świadkowie na Placu opowiadali, że uciekinie- 
rów długo ścigała milicja, niektórzy z protestujących uciekli aż do Kijowsko-Peczerskiej Ławry, która zatrzasnęła przed nimi swoją bramę. Czy przypadkowo? Przecież to cerkiew moskiewskiego patriarchatu...

Janukowycz, nie podpisawszy umowy z UE, pokazał nam wszystkim, że tu, w tym państwie, ani my, ani nasza opinia nic nie znaczymy. Lecz, poszczuwszy na paręset śpiących w namiotach protestujących (przeważnie studentów, którzy i tak już mu niczym nie zagrażali) rozwścieczony Berkut, chciał dowieść, że my to nikt i że może nas rozgnieść niczym mrówki, że może nas zniszczyć jednym ruchem ręki. To już nie była kropla w przepełnionej czarze, a eksplozja gniewu, erupcja gorącej lawy z głębin ukraińskiej duszy. Następnego dnia na Plac Michajłowski spontanicznie wyszło pond 30 tysięcy kijowian. Wtedy pojawiło się inne hasło Majdanu - „Ukraino, powstań!”

Z czasem, znacznie później, po zakończeniu protestów, jeden z wołyńskich dziennikarzy opowiedział mi ciekawy epizod dotyczący wydarzeń po rozpędzeniu Majdanu 30 listopada. Następnego dnia miał możliwość przyjechać do Kijowa na zwołane na 1 grudnia wiece prywatnym autem z kilkoma znajomymi, którzy, jak okazało się potem, byli związani z wołyńskim środowiskiem kryminalnym. Po drodze przypadkowo dowiedział się od nich, że w bagażniku wiozą automaty Kałasznikowa, których zamierzali użyć przeciw Berkutowi i pomścić pobitych studentów. Jednak, kiedy zobaczyli te tłumy ludzi, którzy 1 grudnia wyszli na ulice Kijowa, zrozumieli, że wydarzenia będą rozwijały się już zgodnie $z$ całkiem innym scenariuszem...

\section{Majdan, jaki on był}

Od 30 listopada 2013 r. Ukraina żyła już innym życiem. W Kijowie rozpoczęły się bezterminowe masowe protesty. Jeśli po pobiciu studentów na Placu Michajłowskim na akcję protesta- 
cyjną wyszło kilkadziesiąt tysięcy kijowian, to według różnych danych już 1 grudnia na ludowe wiece przyszło bądź przyjechało z różnych zakątków Ukrainy ponad pół miliona ludzi. Protestujący wrócili na Plac Niepodległości i zajęli pobliskie ulice, aż do rządowego kwartału. Stałe euromajdany pojawiły się faktycznie we wszystkich wielkich miastach Ukrainy. Majdan powstał i w Łucku. Nie był on taki liczny, jak w Kijowie, lecz oddychał tym samym powietrzem wolności co kijowski.

Łucki Majdan mieścił się na centralnym Placu Teatralnym obok pomnika Łesi Ukrainki, teatru dramatycznego i Świętotroickiej katedry. W dni powszednie ludzi pracujących było tu niewielu - większość stanowili emeryci, studenci, młodzież. W wolne dni, w szczególności w niedziele, kiedy ogłaszano ludowe wiece, Plac Teatralny wypełniał się po brzegi. Wtedy przychodzili ludzie i w średnim wieku. Każdy, kto wychodził z soboru, ze służby bożej, zostawał na wiecu. Dookoła placu stali milicjanci i ludzie w cywilu. Ich wygląd zewnętrzny świadczył, że to przedstawiciele służb specjalnych. Jednak ludzie ci tylko obserwowali i na Placu Teatralnym do starć milicji z uczestnikami mityngu nie doszło. Ponieważ Łuck jest miastem niewielkim (poniżej 300 tysięcy ludności), to na Euromajdanie często spotykało się dobrych znajomych, albo takich, których poznało się wcześniej właśnie na Placu. Byli to studenci, dziennikarze, nauczyciele i wykładowcy. Było ich bardzo wielu, podobnie jak - co nie było wcale dziwne - starszych ludzi, którzy przeżyli sowieckie represje i obozy.

Najpierw dominowało odczucie déjà vu - Euromajdan początkowo bardzo przypominał Pomarańczowy Majdan. Nasuwało się jedno zasadnicze pytanie: „Co dalej?” Ono odbijało się w twarzy praktycznie każdego, kto przychodził na plac. Odpowiedzi na to pytanie nie znał nikt. Jednak wszyscy byli zgodni, że bez spełnienia postulatów Majdanu nie opuszczą. I jeśli na początku protestów chodziło tylko o eurointegrację, to teraz 
ludzie domagali się też ukarania kierujących resortami siłowymi i dymisji rządu. I było to zrozumiałe: jeśli przebaczymy rozpędzenie Majdanu w Kijowie, to w mgnieniu oka zdepczą i zniszczą nas wszystkich.

Innego wyjścia ludzie po prostu nie mieli. Przerażała nieprzewidywalność dalszych wydarzeń. Tak - było strasznie. Lecz strasznie było też siadać w domu, patrzeć albo czytać aktualności, widzieć, jak władza - na czele z prezydentem - udaje głupca i nic nie zamierza czynić. Jednak, kiedy wychodziłam na Majdan i spotykałam tam tylu podzielających moje poglądy; tylu, którzy zapewne tak samo jak ja bali się, lecz wiedziałam, że oni też zamierzali tu być do końca, to na duszy od razu robiło się spokojnie i radośnie. Miałam wtedy odczucie, że Majdan był miejscem mojej wyjątkowej duchowej równowagi i spokoju. Miałam zarazem odczucie, że jest to miejsce, gdzie zobowiązana jestem być teraz, jak nigdy przedtem.

Był jeszcze i inny lęk: bałam się, że raptem wszystkim tym ludziom zbraknie uporu, siły, dokuczy im wreszcie ciągłe wystawanie i - wrócą do domu. Jednak po miesiącu, kiedy władza nie tylko nie poszła na żadne ustępstwa, ale przeszła do natarcia na Majdan, a ludzie dalej na nim trwali - ten lęk minął.

Wtedy obawy budziła przyszłość, bo w styczniu stało się jasne, że takiego pokojowego rozwiązania sytuacji, jak w czasie Pomarańczowej Rewolucji nie będzie, że Janukowycz to nie Kuczma, i że na żadne kompromisy nie pójdzie. Oczywista stała się ponadto jego o wiele większa, aniżeli myśleli dotąd Ukraińcy, zależność od Rosji i od samego Putina w szczególności.

Majdan zmienił życie moje i życie mojej rodziny. Najpierw w całości odmienił rytm życia i podział kosztów, szczególnie stosunek do pieniędzy. Ze swojej niewielkiej pensji ukraińskiego profesora małomiasteczkowego uniwersytetu zostawiałam sobie środki tylko na koszty niezbędne i obowiązkowe - komunalne usługi i artykuły żywnościowe. O nową odzież i całą 
resztę, bez której można było się obejść, nie chodziło w ogóle. Pieniądze, które zostawały, szły na Majdan w Łucku, albo na podróże na Majdan w Kijowie. Tak żyło wtedy bardzo wiele osób. Okazało się, że w ogóle można dać sobie radę w życiu z dosyć ograniczonym zestawem rzeczy - wszystko zależy tylko od wyboru dokonanego przez człowieka.

Plac pokazał, kto jest kim w tym życiu naprawdę, obnażył prawdziwą istotę ludzi wokół - w rodzinie, wśród druhów, koleżanek z pracy. Można dużo mówić o sobie, o tym, że jesteś dobry, uczciwy, porządny, szlachetny, że lubisz ludzi, swoją ziemię itd. Ale Majdan to był akurat czas, kiedy każdy Ukrainiec został skazany na wybór, był zmuszony pokazać, kim jest naprawdę. Nikt wtedy nie mógł ukryć swojej prawdziwej natury. Okazało się, ilu jest wśród nas pseudopatriotów, ilu bojowników za Ukrainę silnych tylko w mowie, a ilu prawdziwych. Jak nigdy przedtem ujawniła się prawdziwa natura współczesnych ukraińskich polityków, ich obłuda i cynizm wykazywany w stosunku do narodu. Sama sobie wydawałam się wtedy malutkim, bezradnym ziarnkiem piasku w ogromnym świecie niesprawiedliwości zwanym Ukrainą...

Majdan pokazał i słabość, i siłę każdego z osobna maluczkiego człowieka. W domu, przeglądając aktualności w telewizji czy Internecie, czułam się jak robak, którego nader łatwo może rozgnieść maszyna dyktatorskiej władzy Janukowycza i który nie ma możliwości obrony ani siebie, ani swego domu. Jednak, kiedy wychodziłam na Majdan w Łucku uczucie słabości i bezbronności zmniejszało się wyraźnie. Wtedy pojawiało się bowiem odczucie siebie jako części jakiejś większej całości, która już może obronić, która jest silna i gotowa stawić opór.

Kiedy po raz pierwszy przyjechałam na Majdan do Kijowa, a było to na początku grudnia, przeżyłam niszczycielski potok emocji i uczuć, których nie odczuwałam nigdy przedtem i na pewno nigdy więcej nie odczuję. Bo tego stanu duszy nie moż- 
na wywołać sztucznie, na zamówienie czy za pieniądze, nawet z pomocą najlepszych specjalistów i środków. To był inny świat! Jak gdybym urodziła się po raz drugi, przede wszystkim duszą i sercem.

To była prawdziwa Ukraina, Ukraina o której marzyłam świat wolności, świat wolnych i nieustraszonych ludzi, świat patriotów. Dziesiątki, setki tysięcy, miliony moich braci w duchu. Czy nie po raz pierwszy w ciągu ostatnich lat poczułam się szczęśliwa w swoim państwie? Nie tylko ja! Takich jak ja był cały Majdan, pół Ukrainy! Nadzieja wróciła!

Po raz pierwszy od czasu Pomarańczowej Rewolucji odczułam dumę ze swojego narodu, poczułam się małą cząsteczką dużej siły. Morze światłych i radosnych, dzielnych i twardych twarzy. Oni wiedzieli, po co tu przyszli i było pewne, że nie odejdą bez odniesienia zwycięstwa. „Razem - i do końca” - to jeszcze jedno hasło Majdanu, które po raz pierwszy zadźwięczało dla mnie surowo realistycznie i radośnie, głęboko zapadło w duszy na zawsze.

Od tego czasu jeździłam na Majdan do Kijowa co tydzień. Zazwyczaj w te dni, kiedy nie trzeba było iść do pracy, gdyż w odróżnieniu od Pomarańczowej Rewolucji - która zaczęła się od strajku studentów i wykładowców uczelni - podczas Euromajdanu nasz uniwersytet w Łucku strajku nie ogłosił. Przeciwnie, zgodnie z tajnym rozporządzeniem administracji, zbierano wiadomości o tych wykładowcach i studentach, którzy chodzą na protesty albo przebywają w Kijowie. Chodziły słuchy, że nasz rektor wstąpił do Partii Regionów - jakoby zmusiła go do tego kijowska władza (czy można kogoś zmusić, by został niewolnikiem, jeśli on sam tego w duszy nie chce?) - i nie popierał Majdanu... Chociaż jak teraz mówi, zawsze go popierał...

Jeździłam do Kijowa na jeden, dwa albo trzy dni, zazwyczaj w dni powszednie, gdyż w wolne dni było tam zawsze bardzo wielu ludzi. Uważałam, że jestem tam potrzebniejsza kiedy in- 
dziej. Nie mogłam pozostawać w Kijowie długo - bo w domu starsza mama, rodzina, wreszcie praca. Nie mogłam jednak nie jechać na Majdan, gdy była choćby najmniejsza taka możliwość. Kiedy indziej wychodziliśmy na plac w Łucku. W domu zostawały pieniądze na najniezbędniejsze potrzeby, cała reszta przeznaczana była na Majdan. Nikt nie protestował. To było zrozumiałe samo przez się. Wszyscy żyli tym, co działo się w Kijowie.

Każdorazowo po przyjeździe do Kijowa zauważałam, że Majdan rósł, poszerzał swoje terytorium, zwiększała się liczba jego mieszkańców i liczba namiotów. Cieszyło to, że tu była cała Ukraina, od Wołynia po Donbas. Byli tu nawet krymscy Tatarzy. Uderzała przy tym rozpiętość wieku niepokornych - od 16-, 18-letnich młodzieńców i dziewczyn do 70-, 80-letnich emerytów. Wszystkim zależało. Wszyscy wierzyli, że ich usłyszą...

\section{Oblicze Majdanu}

Na kijowskim Majdanie poznałam wielu bardzo ciekawych ludzi. Na przykład studentkę z Zaporoża, z którą razem szliśmy w kolumnie na pikietę pod budynki rządowe; młodego przedsiębiorcę z obwodu żytomierskiego, który jeździł raz w tygodniu do domu, żeby skontrolować stan swojego przedsiębiorstwa i... narąbać drew mamie, a potem wracał do Kijowa; cały namiot Swobodowców [członków nacjonalistycznej partii "Swoboda”] z Charkowa, którzy skarżyli się, że ich żony są na nich obrażone za udział w Majdanie; Ukraińca w średnim wieku, który przyjechał tu z Niemiec, gdzie pracował, i wielu, wielu innych równie ciekawych ludzi.

Moimi stałymi towarzyszami na kijowskim Majdanie w ciągu owych trzech miesięcy były dwie osoby, kijowianie - Sergij i Marija. Sergij był moim dawnym druhem. Mąż mojej najbliższej przyjaciółki, 56-letni przedsiębiorca, tłumacz z wykształcenia, Rosjanin z pochodzenia (rodem z ziemi briańskiej), który 
był na Euromajdanie od pierwszego do ostatniego dnia, razem z Samoobroną Majdanu przeżył wszystkie starcia z milicją i krwawe dni 18-2o lutego, był też ranny w nogę. Należał do tzw. Wołyńskiej Sotni, aczkolwiek mieszkał w Kijowie. W jego mieszkaniu stale nocowali „majdanowcy”. Sergij nigdy nie był członkiem żadnej partii, nie miał żadnych wyjątkowych ideologicznych przekonań. Jemu, tak jak i mnie, i tysiącom innych osób, chodziło o wolność i przyszłość dzieci, której nikt nie miał prawa nam odbierać.

Z Mariją poznałam się podczas swojego pierwszego pobytu w Kijowie - przypadkowo, podczas pikiety przed siedzibą Rady Najwyższej. Znajdowaliśmy się wtedy w pobliżu Parku Mariińskiego (to był jeszcze czas, kiedy można było doń wejść). Marija okazała się również wołynianką, jednak już od dawna mieszkała w Kijowie. Była kobietą w wieku emerytalnym, która przychodziła na Majdan codziennie - jak do pracy. Zjawiała się rano, kiedy było tu mniej ludzi, i powracała do domu wieczorem, kiedy po pracy na Majdanie spotykało się wielu kijowian. I tak codziennie przez trzy miesiące...

Od naszego pierwszego spotkania koło Parku Mariińskiego od razu zauważyłam, że Marija jest bardzo odważną kobietą. Już wtedy do parku zwożeni byli „antymajdanowcy” (przeważnie ze wschodnich obwodów Ukrainy) i „tituszki”. To drugie określenie pojawiło się w obiegu publicznym w 2013 r. Pochodziło od nazwiska młodego sportowca Wadima Tituszki, który - wraz z innymi takimi jak on sam - na zamówienie władzy w maju tego roku podczas akcji protestacyjnej pobił dziennikarkę Olgę Snisarczuk. Dziennikarzom udało się to sfilmować. Incydent nabrał rozgłosu. Wadima skazano na karę w zawieszeniu. Później przepraszał i bardzo żałował. Podczas Majdanu pomagał „majdanowcom”, a kiedy zaczęła się wojna [na wschodzie Ukrainy], to użalał się, że nie może zgłosić się na ochotnika, gdyż ciąży na nim wyrok w zawieszeniu. Młody, 
głupi dzieciak został okrutnie wykorzystany przez władzę dla jej własnych celów. Po tym wydarzeniu ukraińscy dziennikarze nazwą „tituszki” zaczęli określać wszystkich, których rządzący „wynajmowali” ze sportowego czy kryminalnego środowiska do walki z protestującymi.

Dla „antymajdanowców” ze sceny brzmiały radzieckie piosenki, występowali deputowani z Partii Regionów i artyści. Opowiadali oni o faszystach-,,majdanowcach”, amerykańskich agentach i o zgodnie z prawem wybranym prezydencie Janukowyczu, a także o braterskiej Rosji. Później byli oni szczelnie izolowani od „majdanowców” przez milicję, lecz wtedy, w grudniu, można było jeszcze do nich podejść i nawet porozmawiać. Większość z tych ludzi była ubrana bardzo biednie, miała prymitywny, poirytowany wyraz twarzy, wielu bez trudu można było scharakteryzować jako uzależnionych od narkotyków lub alkoholu. Jednak wśród tej masy „lumpów” można było dostrzec i dosyć przyzwoicie ubranych ludzi - kobiety i mężczyzn w drogiej odzieży. Byli to najprawdopodobniej „ideowcy”, którzy święcie wierzyli w uczciwość Wiktora Janukowycza i pragnęli możliwie jak szybciej połączyć się z Rosją.

We mnie ci ludzie wywoływali żal i lęk, toteż nie ryzykowałam rozmowy z nimi ani wtedy, ani później. A Marija weszła do ich i wśród tłumu udało się jej porozmawiać z kobietą z Doniecka, którą zmuszono do przyjazdu. Jej 16-letni syn należał do donieckich ultras. Takich w Doniecku uważano za „nieprawomyślnych" i umieszczano ich w milicyjnej ewidencji. Jej syn został tam odnotowany, chociaż nigdy nic złego nikomu nie zrobił. Kiedy dla Partii Regionów w Doniecku trzeba było organizować masówki, to do tej kobiety dzwoniono i mówiono jej, gdzie ma się stawić. Jeśli rezygnowała z przyjścia, to zmuszano ją do płacenia - aby „wykupić się” - nie mniej niż 200 hrywien za dzień, grożąc wtrąceniem syna do więzienia. Tak było i tym razem. Nie miała pieniędzy na "wykup" i aby syn nie trafił do 
więzienia, pojechała do Kijowa na Antymajdan. Zapewne takich jak ona było wtedy sporo w Parku Mariińskim.

Kijowski Majdan w grudniu był niezwykle optymistyczny. Ludzie wierzyli w swoje marzenie. Tylu radosnych, uskrzydlonych, wzniosłych twarzy w jednym miejscu nie widziałam nigdzie od czasu Pomarańczowej Rewolucji - i zapewne już więcej nie zobaczę. Wszyscy rozumieli się w pół słowa. Nikt nie wiedział, co będzie jutro, lecz pojmował, że należy tu przychodzić i stać. Kiedy pociąg Kowel-Kijów o 6 rano przyjeżdżał do Kijowa, to akurat wpadałam na Majdan na poranną modlitwę, która odbywała się codziennie bez względu na pogodę i wydarzenia. Na Scenę Majdanu wychodzili duchowni różnych konfesji i modlili się wszyscy razem. Poza tym, obok sceny w namiocie była przygotowana kaplica, w której każdy chętny mógł pomodlić się w dowolnym czasie. Akurat wtedy mężczyźni z Samoobrony Placu, ubrani w ciepłą odzież, zmieniali nocne patrole na dzienne. Później była poranna herbata z kanapkami, ze sceny informowano o wydarzeniach dnia, formowały się kolumny i „majdanowcy” szli ze swoimi postulatami pod budynki rządowe. Tak było codziennie. Naprawdę była to trudna, niekiedy jednostajna praca, którą należało wykonywać, aby osiągnąć cel.

Na początku grudnia na pewno nikt nie myślał, że wszystko będzie trwać tak długo i będzie mieć tak okrutne zakończenie. Po doświadczeniach poprzedniej rewolucji wydawało się pewne, że władza powinna pójść na ustępstwa. Postulaty ludzi nie były niewykonalne. Gdyby Janukowycz zgodził się na dymisję rządu, albo chociaż zdymisjonował ministra spraw wewnętrznych, Zacharczenkę i ukarał zamieszanych w pobicie studentów, to protesty by ustały. Jak się jednak okazało, stopień cynizmu Janukowycza i jego obozu był trudny do przewidzenia. Któż by wtedy pomyślał, że ludzie nic dla niego nie znaczą, że są jedynie środkiem prowadzącym do osiągnięcia jego celów, 
a Majdan jest przysłowiowym czyrakiem, który utrudnia życie, więc należy go zlikwidować.

Ludzie czekali na ustępstwa władzy, a Janukowycz spodziewał się, że do Nowego Roku, a najpóźniej do Bożego Narodzenia [7 stycznia] Majdan rozejdzie się. Religijni mieszkańcy Ukrainy Zachodniej, w jego przekonaniu, mieli jeszcze w końcu grudnia, na katolickie Boże Narodzenie, pojechać do domów. Tak się nie stało. I Nowy Rok, i Boże Narodzenie wszyscy świętowali na Majdanie. Przyjeżdżały muzyczne zespoły, piosenkarze, muzycy z całej Ukrainy, żeby tu wystąpić. Na scenę wychodzili zwyczajni ludzie - czytali poezje, śpiewali $\mathrm{z}$ akompaniamentem gitary, bandury i harmonii, modlili się, opowiadali historie ze swojego życia. To był inny świat! Nowy kraj w centrum Kijowa, żyjący według nowych praw i reguł wolny, niezależny, czysty i światły.

Plac był zawsze czysty, chociaż palono ogniska i przygotowywano w kotłach jedzenie. Wszędzie rzetelnie sprzątano, dookoła stały śmietniki, zwożono drwa i wywożono śmieci. To było miejsce wielkiej kultury. Nie widziałam, żeby ktoś rzucał śmieci czy niedopałki na ziemię. Wszyscy byli niezwykle uprzejmi dla siebie nawzajem i zawsze uśmiechnięci. Nigdy nie widziałam pijanych, nie słyszałam wulgarnych słów, nie zauważyłam niesnasek czy starć wśród „majdanowców”. Kiedy kończyły się pikiety i wracały na Majdan, to zbierano się wokół ulicznego fortepianu, śpiewano Czerwienna rutę i Wodospad, Mariczkę i Czeremszynę.

Bardzo wiele osób brało urlopy, żeby przyjechać na Majdan. Cały grudzień w Kijowie na Majdanie dyżurował lekarz-kardiolog z Łuckiego miejskiego szpitala. Niewiarogodną radością przepełniała się dusza, kiedy tam w Kijowie na Majdanie spotkałam profesora folkloru z naszego uniwersytetu, kiedy tam często spotykałam swoich byłych i ówczesnych studentów. Często do Kijowa na Majdan przyjeżdżał mój syn, wtedy 
student Lwowskiego konserwatorium. Przez większość swojego wolnego czasu dyżurował na lwowskim Majdanie w nocy, gdyż w dzień musiał chodzić na zajęcia. Kiedy tylko była okazja - jechał do Kijowa. Pewnego razu, kiedy, jak oczekiwano, we Lwowie zjawić się miał Berkut, aby rozpędzać lwowski Plac i panowała tam napięta atmosfera zagrożenia, jeden nasz znajomy powiedział mu: „Dlaczego tu przyszedłeś? Ty skrzypek, tu bardzo niebezpiecznie. Ty artysta, powinieneś myśleć o sztuce”. Wtedy odpowiedział: „Tutaj wszyscy to artyści. Nie mogę teraz myśleć o sztuce".

\section{Życie Majdanu}

Ludzie na Majdanie dokonywali cudów samoorganizacji. Tworzyli swoje państwo w państwie; takie, którego chcieli; sami je finansowali i rozbudowywali. Przez Majdan codziennie przechodziły tysiące osób. Wszyscy masowo wrzucali pieniądze do skrzynek „na życie” dla "majdanowców”. Majdan utrzymywał sam siebie. Wielu kijowian przez te trzy miesiące protestów pracowało dla Majdanu - przynosiło pieniądze, odzież; przywoziło paliwo i drwa. Marija opowiadała o swojej sąsiadce, która wynajmowała dwa mieszkania w Kijowie, a cały dochód z nich przynosiła na Majdan. Opowiadała o innej swojej znajomej, która każdego dnia przygotowywała pierogi czy placki i nosiła „majdanowcom” jedzenie.

Oprócz namiotów i punktów spotkań opozycyjnych partii i deputowanych, na Placu Niepodległości było mnóstwo namiotów różnych społecznych organizacji, a jeszcze więcej namiotów zwyczajnych ludzi ze wszystkich zakątków Ukrainy - i Doniecka, i Charkowa, i Krymu, nie mówiąc już oczywiście o zachodniej i centralnej Ukrainie. Oddzielnie na Placu stały namioty weteranów afgańskiej wojny i byłych wojskowych. Każdy z tych miniobozów albo ich strukturalnych jednostek pełnił swoją funkcję 
- ktoś wchodził do Samoobrony, ktoś przygotowywał jedzenie i sprzątał, ktoś szedł na pikietę. Te malutkie grupki ludzi formowały duży organizm pod nazwą Majdan. Wypracował on własne reguły życia - prohibicję, palenie tylko w przeznaczonych do tego miejscach, czystość, uzgodnienie zewnętrznych działań ze społeczną radą Majdanu i inne.

Uderzała kreatywność i bezgraniczna wyobraźnia tych ludzi. Później, gdy protestujący na Placu Niepodległości „wywojowali” od władzy noworoczną choinkę, przystroili ją zgodnie z rewolucyjną „manierą”. To była zupełnie niewiarogodna noworoczna choinka. Piękniejszej w moim życiu nie było i nie będzie. Ze sztandarami Ukrainy, Polski, Gruzji, Litwy, Białorusi - wszystkich państw, z których namioty były na placu i których obywatele nas wspierali. Z hasłami Majdanu i rozmaitymi rysunkami oraz karykaturami. Namioty Majdanu, sztachety, ściany, barykady, reklamowe tablice również zostały pokryte plakatami, rysunkami i karykaturami. Wszyscy śmiali się i oddychali wiarą w zwycięstwo. W końcu grudnia na Chreszczatyku przed ostatnią barykadą na skręcie w ulicę Bohdana Chmielnickiego do wszystkich majdanowskich artystycznych figlów dodali figurę Janukowycza w więziennej klatce. To było zadziwiająco śmiałe i prorocze, wszyscy spodziewali się, że tak się to zakończy.

Grudniowy Majdan upamiętnił się Marszem Miliona i koncertem „Oceanu Elzy”. Wtedy na Marsz Miliona, na Plac, ulicę Chreszczatyk i pobliskie ulice i place wyszło rekordowo wielu ludzi - zgodnie z informacjami organizatorów było ich ponad milion. Prawie tyle przyjechało też na koncert najpopularniejszej ukraińskiej grupy rockowej. Wtedy cały Majdan, pobliskie ulice i place aż do północy rozświetlał milion latarek. Później władza w grudniu kilkakrotnie bezskutecznie starała się oczyścić Majdan. 
Świadkiem szturmu siedziby kijowskiego merostwa na Chreszczatyku była i moja znajoma Marija. Opowiadała ona, że w domu, jeszcze przed świtem usłyszała, iż ulicami jeździ samochód i nadaje komunikat: „Kijowie, wstawaj!” Szybko zebrawszy się, Marija pojechała na Majdan. Metro w centrum nie kursowało (wiadomo, że nie przypadkowo). Trzeba było pieszo dotrzeć do Chreszczatyka. Kiedy znalazła się pod siedzibą kijowskiego merostwa, zobaczyła, że kilka szeregów Samoobrony Majdanu, stanąwszy w łańcuchu, opiera się natarciu Berkutu. Co chwila dobiegali nowi ludzie. $\mathrm{Z}$ okna górnej kondygnacji budynku „majdanowcy” przeciągnęli wąż i zaczęli polewać berkutowców wodą. Ponieważ panował trzaskający mróz, szybko przed budynkiem utworzył się lód, na którym nie można było utrzymać równowagi. Dzięki temu, a także dzięki kijowianom, którzy szybko zareagowali na apele i przyjechali na Majdan, szturm udało się powstrzymać. Marija opowiadała, że z tego szturmu najlepiej zapamiętała młodą kijowiankę - „businesswoman". Przyjechała ona na wezwanie o pomoc bardzo drogim samochodem, w butach na ogromnych obcasach, w cienkich rajstopach i krótkiej spódniczce. Stała razem z innymi „majdanowcami" naprzeciw Berkutu, odpierając natarcie. Jej obcasy rozjeżdżały się na śliskim asfalcie, spódnica rozeszła się wzdłuż szwu, ale ona na to nie zważała, starając się utrzymać łańcuch protestujących.

W grudniu władzy nie udało się oczyścić Majdanu i uwolnić budynków od „majdanowców”, lecz w efekcie siłowych działań udało jej się w całości wyprzeć posterunki protestujących z rządowego kwartału, do Placu Niepodległości i ulicy Chreszczatyk. Na początku grudnia, podczas pikiet przed siedzibami Rady Najwyższej i rządu, staliśmy oko w oko z „siłowikami" i nawet mogliśmy z nimi rozmawiać, często byli to młodzi chłopcy, żołnierze specjalnych wojskowych sił wewnętrznych, 
którzy w ogóle nie chcieli tu być, lecz nie mieli wyboru, zmuszeni do wykonywania rozkazu dowództwa.

Po wyparciu „majdanowców” z rządowego kwartału „siłowiki" oddzieliły się od protestujących przegrodami z autobusów, samochodów i innych przeszkód. Ponadto w stanie gotowości pozostawały uzbrojone pododdziały specjalne i agresywne „tituszki”, które chowały się za wysuniętymi szeregami młodych żołnierzy.

Za każdym razem, kiedy „siłowiki” szturmowały Majdan, zaczynały dzwonić dzwony Michajłowskiego Soboru. Wtedy kijowianie wiedzieli, że potrzebna jest natychmiastowa pomoc. Mój przyjaciel Sergij, który w szeregach Samoobrony Majdanu odpierał wszystkie ataki Berkutu od strony Placu Europejskiego i ulicy Instytuckiej, opowiadał, że wtedy - w owych krytycznych chwilach - dużą rolę w koordynowaniu działań odegrał Eugeniusz Nyszczuk, którego zwano „głosem Majdanu”. Aktor ten, znany był Ukraińcom jeszcze z okresu Pomarańczowej Rewolucji. Wtedy również występował na scenie przed protestującymi. Kiedy rozpoczął się Euromajdan, ponownie wziął na siebie zadanie prowadzącego. Podczas natarć „siłowików”, według słów Sergija, właśnie on z sceny kierował ludźmi, podpowiadał, gdzie grozi przełamanie obrony, gdzie należy się przesunąć, skąd nadchodzi odsiecz dla Berkutu. Później, w lutym, kiedy Majdan stanął w ogniu, właśnie on nadal podpowiadał „majdanowcom” ze sceny, gdzie gaśnie opór, gdzie grozi przełamanie obrony, dokąd należy biec. Wszyscy go słyszeli i Sergij był przekonany, że w tych kryzysowych chwilach właśnie Nyszczuk swoimi działaniami zrobił bardzo dużo dla ratowania Majdanu.

„Majdanowcy” sami zorganizowali swą egzystencję, przygotowywali jedzenie, leczyli się, odpoczywali, kontrolowali finanse i planowali kolejny dzień. To był dziwny świat, przepełniony duchem porozumienia, braterstwa, wspierania się, patriotyzmu, wspólnego celu. Ludzie wierzyli, że władza ich 
usłyszy. Ten duch i towarzyszący mu humor był niemożliwy do odczucia gdzie indziej. Nie można go odtworzyć na scenie ani przekazać słowami. Można go tylko „usłyszeć sercem”, kiedy każdy, kto stoi obok, całkiem nieznajomy, porozumiewa się z tobą spojrzeniem i gestem, rozumie cię w pół słowa. Kiedy każdy, kto jest obok, to twój duchowy brat.

Tu w Kijowie na Majdanie po raz pierwszy stanęłam oko w oko z ludźmi gotowymi do oddania życia za Ukrainę. To byli zwyczajni ludzie, młodzi i w średnim wieku, przeważnie mężczyźni - nauczyciele, inżynierowie, programiści, studenci, uczeni, przedsiębiorcy - którzy powtarzali, że odejdą stąd tylko po zwycięstwie. Byłam szczęśliwa, że tacy ludzie są na świecie i że są to Ukraińcy. W ciągu trzech miesięcy poznałam dziesiątki ludzi z Charkowa, Zaporoża, Lwowa, Żytomierza. Ze wszystkich zakątków Ukrainy. Nikt nikogo nie pytał, dlaczego tu przyjechał. Wszyscy pytali, co będzie dalej.

\section{Pętla zaciska się}

Po bożonarodzeniowych świętach, w środku stycznia dla wszystkich „majdanowców” stało się jasne, że władza nic nie zamierza zmieniać. Na Majdanie odczuwalny stał się wzrost napięcia i niezadowolenia. Upowszechniało się przekonanie, że należy przejść do ataku... Pewna część protestujących sądziła, że trzeba wytrwać do końca - do wiosny, do lata, ile będzie konieczne. Pozostali uważali, że ponieważ pokojową drogą niczego się nie uzyska, należy walczyć z bronią w ręku. Tylko skąd ją wziąć? Jeszcze w styczniu krążyły pogłoski, że rzekomo gdzieś na Majdanie schowana jest broń. I nawet zagraniczni dyplomaci, którzy przychodzili na Majdan, starali się zaglądać do wszystkich zakamarków siedzib „majdanowców”, żeby dowiedzieć się, czy nie ukrywają oni gdzieś broń. Jednak krwawe starcia „majdanowców” z milicją w styczniu i lutym 
2014 r. pokazały, że żadnej broni na Majdanie nie było. Z wyjątkiem koktajli Mołotowa, drągów i tarcz własnego wyrobu protestujący nie dysponowali żadną inną bronią. Aż do dni między 18 a 20 lutego, kiedy lwowianie (informacja podawana na Majdanie) wykradli u siebie ze składu broń i przedarli się przez łańcuchy milicji do Kijowa. Wtedy dopiero pojawiła się na Majdanie broń, lecz kiedy dowiedzieli się o tym berkutowcy, zaczęli się natychmiast wycofywać.

Styczniowy Majdan stał się bardziej ponury, niż ten w grudniu. Brak jakichkolwiek rezultatów protestu wywoływał różne myśli i uczucia - smutek, rozczarowanie, zmieszanie. Generalnie wszyscy rozumieli, że należy wytrwać do końca, że nie wolno cofnąć się, bo Janukowycz pojedynczo wszystkich zniszczy i „połknie” wraz z Putinem Ukrainę. Jednak, co czynić dalej, nie wiedział nikt, ani zwykli „majdanowcy”, ani politycy. Dlatego, o ile życie Majdanu, jego samoorganizacja, były skoordynowane i przemyślane, to Majdanem jako siłą, która przeciwstawia się władzy, strategicznie nikt nie kierował, pomimo opinii głoszonych przez niektórych cyników, że był on projektem amerykańskich służb specjalnych. Sergij, który spędził wiele czasu na nocnych patrolach na Majdanie i przy ogniskach, spotykając wielu ówczesnych polityków (Jurija Łucenkę, Tarasa Czornowoła i innych), opowiadał, że wtedy, w styczniu, nikt na Majdanie nie wiedział, co robić dalej. Zapewne nie wiedział co robić także i Janukowycz. Bo nie stało się tak, jak tego oczekiwał. Ludzie nie odeszli z Majdanu ani na Nowy Rok, ani na Boże Narodzenie, ani na popularne imieniny Wasilija. Natomiast bodźcem do dalszej radykalizacji Majdanu stały się przyjęte przez Radę Najwyższą 16 stycznia 2014 r. tak zwane dyktatorskie prawa, zgodnie z którymi można było aresztować dowolnego człowieka, który był w hełmie czy z zakrytą twarzą albo miał pałkę, oraz zatrzymać samochód czy inny pojazd, który poruszał się w kolumnie liczącej powyżej trzech pojazdów. 
$\mathrm{Na}$ ostatnie w styczniu wielkie religijne Święto Jordanu (19 stycznia) przypada początek krwawych starć na Majdanie, które zakończyły się śmiercią pierwszych „majdanowców”. Po niedzielnym, ludowym wiecu, na którym decydowano, jak działać dalej, niespodziewanie przedstawiciele społecznej organizacji Automajdan wezwali ze sceny wszystkich do zablokowania Rady Najwyższej. To było bardzo emocjonalne wystąpienie i wydało mi się ono prowokacją. Bo jaki był sens, aby w niedzielę, w trzaskający mróz, iść do rządowego kwartału, jeśli tam nikogo nie było? W ponad 20-stopniowym mrozie wystać tam przez całą noc, do następnego dnia, po prostu nie było można. Jednak najbardziej radykalne prawicowe siły Majdanu zdecydowały się na to posunięcie. Okazało się, że kwartał rządowy już blokowany jest przez autobusy milicji, uzbrojonych „siłowików” i „tituszki”. Zaczęły się walki. Trwały one do następnego dnia i w ich wyniku zginęły cztery osoby. Pierwsze śmierci „majdanowców” zszokowały kraj. Jeszcze w grudniu, po pierwszych szturmach Majdanu, budziliśmy się w nocy i z lękiem włączaliśmy 5. albo 24. kanał, żeby przekonać się, że Majdan nie został „oczyszczony”. A w styczniu, kiedy byliśmy w domu, już co godzinę włączaliśmy telewizor albo Internet, żeby zorientować się, czy nikt więcej nie zginął.

Po 19 stycznia ulice Kijowa stały się dla „majdanowców” bardzo niebezpieczne. Bezpieczniej było na samym Majdanie. Poza nim masowo zaczęto porywać ludzi z „majdanowską" symboliką, bić ich, kaleczyć, aresztować. Przedtem na Majdanie rozdawano wstążki i chorągiewki, a ludzie z radością je brali i z dumą nosili. Na moich dwóch torbach, z którymi chodziłam na Majdan, te wstążki zachowały się jeszcze do tej pory. Wtedy, w końcu stycznia, rozdając „majdanowskie” symbole, mówiono: „Jeśli boicie się, to nie bierzcie”. Robiło się wręcz przerażająco. Było oczywiste, że sprężyna jest ściskana i wystrzeli. Gdzie i jak?... 
Po 25 stycznia nie mogłam pojechać na Majdan do Kijowa z powodu choroby wnuka, z którym byłam w szpitalu. Zaglądałam na Łucki Majdan i pomagałam, jak mogłam. Nogi przymarzały do ziemi od trzaskającego mrozu, który zapanował w styczniu, lecz ludzie stali w Łucku i pod siedzibą rady obwodowej i na Placu Teatralnym, później pod wojskową strefą, którą blokowano, żeby nikt nie pojechał do Kijowa na pomoc berkutowcom. Wtedy przez telefon Marija opowiadała mi o kijowskim Majdanie. Najbardziej zapamiętałam jej słowa: „Obowiązkowo zwyciężymy! W niedzielę był 28-stopniowy mróz, a dziewczyny z Charkowa obierały ziemniaki. Nóż przywierał do rąk od mrozu. Przygotowywaliśmy zupę dla »majdanowców«. Zwyciężymy!” Opowiadała jeszcze, jak razem z duchownymi podchodziła w te styczniowe dni do berkutowców na ulicy Hruszewskiego, gdzie toczyły się największe walki, klękała przed nimi i prosiła ich, by nie strzelali do ludzi. A kiedy wracała, to ktoś ze strony „siłowików” wystrzelił jej pod nogi...

Wtedy, w końcu stycznia, mój syn po raz kolejny wybierał się ze Lwowa na Majdan do Kijowa. Mój mąż zabraniał mu jechać, przekonując, że on skrzypek, że na jego przygotowanie jako fachowca państwo poświęciło ponad dziesięć lat - toż on powinien zajmować się muzyką! Na to padła odpowiedź: „Nie możemy przegrać. Jak nie ja, to kto? Nie mogę ani grać, ani chodzić na zajęcia, ani być w domu. Nie mogę nic robić. Muszę jechać. Jeśli każdy pozostanie w domu, to cóż wtedy?...”

Napięcie pomiędzy Placem i władzą narastało. Starcia, z krótkimi przerwami, trwały. Jeden z moich kolegów - wołyński dziennikarz, redaktor miejscowej gazety - Wiktor Trofymczuk wtedy, w końcu stycznia, wziął urlop i również pojechał na Plac, akurat na swoje urodziny. Wyjaśniał mi później: „Kiedy mój syn urośnie i spyta mnie: Tato, co robiłeś, kiedy był Majdan w Kijowie? To co mu wtedy odpowiem?! Że siedziałem w domu?!" 


\section{Przełom}

Najgorzej było na Majdanie w lutym. Było oczywiste, że sytuacja szybko zaostrza się i pokojowe rozwiązanie stawało się czymś coraz bardziej odległym. 17 lutego wróciliśmy po kolejnej podróży do Kijowa na Majdan. Musiałam iść do pracy, a syn - na zajęcia. Wiedzieliśmy, że na 18 lutego jest zaplanowany pokojowy pochód protestujących pod siedzibę Rady Najwyższej z postulatami powrotu do Konstytucji z 2004 r., czyli do parlamentarno-prezydenckiej formy rządów, którą Janukowycz samowolnie zmienił na prezydencką. Nikt nie spodziewał się, że „siłowiki” przekształcą ten pochód w rzeź. Wtedy, 18 lutego, pod Radą Najwyższą była moja przyjaciółka Marija. Już wcześniej, kiedy chodziliśmy na pikiety do rządowego kwartału, mówiła ona, że budynki wokół są obsadzone przez uzbrojonych ludzi, że na wszystkich dachach znajdują się snajperzy, a w podziemnych przejściach pomiędzy budynkami ulokowano uzbrojone służby wewnętrzne wojska. Wiedziało o tym wiele osób na Majdanie. Przecież krewni i znajomi wielu „majdanowców” pracowali w milicji, w służbie bezpieczeństwa i w innych siłowych strukturach. Znaczna ich część w głębi duszy popierała Majdan, lecz nie każdy człowiek miał taką siłę woli, aby napisać meldunek i odejść ze służby z uwagi na swoje przekonania. Komuś do emerytury zostawało na przykłąd kilka lat albo miesięcy. To był trudny wybór.

Otóż 18 lutego skrzyżowania i ulice rządowego kwartału przekształciły się w rzeźnię. Z dachów „siłowiki” rzucały na „majdanowców” granaty. Demonstrantów bito, szarpano i wrzucano ich do więźniarek. Protestujący odpowiadali kamieniami wyrywanymi z ulic, petardami i pałkami. Wtedy okazało się też, że wśród milicjantów jest wiele przyzwoitych osób. Z opowieści Mariji o tym tragicznym dniu wiem, że wiele prostych osób demonstrowało wyjątkowe męstwo i udzielało sobie wzajemnie pomocy. 
Zdarzyło się nawet kilka komicznych sytuacji. Kiedy zapaliło się biuro Partii Regionów, które ulokowane było w rządowym kwartale, ktoś zawiadomił strażaków. A jedna z kobiet, ubrana w drogie futro, położyła się wtedy na drodze przed ich samochodem ze słowami: „Nie puszczę! Niechaj płoną, kanalie!” Na Majdanie koło Parku Mariińskiego i na pobliskich ulicach unosił się dym od wybuchów granatów i żeby móc oddychać, należało się pochylić. Jedna starsza kobieta przysiadła na ziemi, aby odetchnąć, wypić z termosu łyk herbaty i zjeść kawałek kanapki. Zapewne była cukrzyczką, bo robiła to szybko ze słowami wypowiadanymi po rosyjsku: „To teraz coś przegryzę, żeby zrobiło mi się lepiej i wtedy już im pokażę!” Były jednak i dosyć smutne sytuacje. Kiedy Marija z innymi „majdanowcami” uciekała przed „siłowikami” ulicą Instytucką na Plac, to w oknie drogiego salonu fryzjerskiego widziała siedzącą w fotelu młodą dziewczynę, której inna układała fryzurę. Oto tak różni byli ludzie i różne światy...

W te trzy okropne dni od 18 do 20 lutego na Majdanie byli najodważniejsi. Czy bali się? Tak. Wszyscy, którzy wtedy tam byli, mówili, że się bali. Czy można potępiać tych, którzy przestraszyli się i nie chcieli się narażać? Zapewne nie, bo każdy ma swój wewnętrzny potencjał, poziom, który trudno przeskoczyć. Sergij opowiadał, że w nocy z 18 na 19 lutego był szturm Majdanu, grożący jego całkowitym spacyfikowaniem i likwidacją. Jego, wraz z innymi członkami Samoobrony z „Wołyńskiej Sotni”, rozmieszczono w szeregu nieopodal sceny, w pobliżu wejścia do metra. Jednak już po kilku minutach z tego szeregu pozostało tylko kilku mężczyzn, a reszta gdzieś się „zapodziała”. W tę noc z Majdanu zniknęli prawie wszyscy politycy - przynajmniej Sergij, który był tam cały czas, mówił, że nie widział żadnego, oprócz Jegora Sobolewa. A jeszcze na scenie z „majdanowcami” był ciągle Eugenij Nyszczuk, dzięki któremu protestujący wiedzieli, gdzie mają się kierować, gdzie grozi przełamanie obrony. 
Majdanem nikt nie kierował. W każdym konkretnym miejscu ludzie wspólnie podejmowali decyzję odpowiednią do sytuacji. W nocy, kiedy należało palić ogniska, żeby nie przepuścić na Majdan „siłowików”, a drew już nie było, ogniska podtrzymywały zwyczajne kobiety - starsze i młode. One bez strachu przyciągały z pobliskich podwórców i ulic wszystko, co mogło spłonąć. Rzucały w ogień namioty, rzeczy, materace - wszystko, byle tylko ogień nie zgasł. Wtedy było tam wielu bezimiennych bohaterów, którymi stawali się zwyczajni, przeciętni ludzie.

Ciekawy jest jeszcze jeden, mistyczny wręcz szczegół - przez cały okres protestów, kiedy protestujący palili ogniska, żeby zatrzymać „siłowików”, wiatr dziwnym trafem dął w stronę szturmujących. „Majdanowcy” wszystko widzieli, natomiast dym stale pokrywał kolumny berkutowców, nie dając im nic zobaczyć i swobodnie oddychać.

Kiedy „siłowiki” podpalili Dom Związków Zawodowych, gdzie mieścił się sztab Majdanu i Prawego Sektora, i zablokowali górne kondygnacje z rannymi „majdanowcami”, to z okna jednego z pięter wyjrzał chłopiec, wzywając pomocy. Nie mógł wyjść z lokalu z powodu pożaru, a bał się skakać, bo było za wysoko. Wtedy jeden z „majdanowców”, młody chłopak, dostał się do niego po balkonach po zewnętrznej ścianie, rzucił linę i pomógł mu zejść, ratując życie. W chaosie wydarzeń nikt tego nie nagrał ani na kamerę wideo, ani aparatem fotograficznym. A kiedy uratowany opamiętał się, to wybawcy już nie było obok. Nikt nawet nie zapisał imienia prawdziwego bohatera. Takich sytuacji było na Majdanie mnóstwo.

O wydarzeniach z 18 lutego w Kijowie dowiedziałam się w pracy. Studenci i wykładowcy od razu porzucili zajęcia. Ktoś wybierał się do Kijowa, a ktoś po prostu korzystał z okazji, aby odpocząć. Do mnie zadzwonił syn, że jedzie do Kijowa, więc natychmiast pojechałam do Lwowa, żeby naprędce chociaż kupić dla niego kamizelkę kuloodporną. Nie mam słów, żeby prze- 
kazać mój ówczesny wewnętrzny stan. Chciałam jechać razem z synem, lecz on bardzo prosił, żebym pozostała w domu, bo wtedy będzie musiał myśleć nie tylko o swoim bezpieczeństwie, lecz jeszcze i o moim - a to skomplikuje sytuację. Kiedy przyszliśmy do sztabu oporu we Lwowie, skąd odjeżdżały autobusy do Kijowa, to zrozumiałam, że Majdan zwycięży. Była tu masa ludzi, przeważnie mężczyzn. Co pół godziny do Kijowa odjeżdżał kolejny autobus, wypełniony ochotnikami w młodym, średnim, starszym wieku, nawet całkiem siwymi. Zdawało mi się, że do Kijowa wyrusza cała męska ludność Lwowa. Z czasem dowiedziałam się, że ze Lwowa jechali do Kijowa mężczyźni z Podkarpacia, z obwodu lwowskiego i wszystkich innych pobliskich regionów. Kobiet do autobusów nie brano, chyba że były lekarkami lub pielęgniarkami. Kiedy zobaczyłam to wszystko, zrozumiałam całą głęboką istotę słów: „Razem - i do końca!”

Noc z 19 na 20 lutego była też straszna i okazała się rozstrzygająca dla Placu. Protestującym udało się odeprzeć natarcie „siłowików” kosztem życia ponad setki „majdanowców”, ludzi nadzwyczajnego męstwa i niewiarygodnej siły ducha. Dla ich wsparcia przyjechało wiele osób z różnych regionów, przerwawszy milicyjne blokady wokół Kijowa. Przywieźli broń i to ostatecznie przeważyło sytuację na korzyść Majdanu...

Kiedy dowiedzieliśmy się, że Janukowycz wyjechał z Kijowa, to chciało się nam skakać jakbyśmy byli dziećmi, wszystkich obejmować i krzyczeć: „Hurrra! Zwyciężyliśmy! Ukraina zwyciężyła!” Duszę przepełniała radość, poczucie dumy i zarazem ból i smutek na myśl o poległych. Takie uczucia zdarzają się, zapewne tylko raz w życiu, bo tylko raz w moim życiu był taki Majdan.

Następnym razem trafiłam do Kijowa na Majdan 25 lutego. To był już inny Majdan. On oszołomił... zwęgloną ziemią, czarną trawą, spalonymi budynkami i drzewami, opalonymi ścianami... i żywymi kwiatami na miejscach byłych barykad, 
gdzie zginęło ponad stu „majdanowców”, a blisko tysiąc zostało ciężko rannych.

Majdan przypominał pogorzelisko, wyścielone górami żywych kwiatów. Tu przychodziły bezustannym potokiem nieme od rozpaczy i poczucia nieszczęścia tysiące Ukraińców. Ciężko było uwierzyć, że Ukrainiec strzelał do nieuzbrojonego Ukraińca, że władza, wybrana przez naród, kazała strzelać do swoich obywateli. To była jakaś niesamowita sytuacja: zwyciężyliśmy, lecz za jaką cenę?!

Nikt wtedy nie domyślał się, że to jest dopiero początek krwawej wojny o wolność Ukrainy, która zabierze jeszcze niejedną setkę istnień. Wtedy zdawało się nam, że wszystko co najgorsze należy do przeszłości...

Tłumaczenie zjęzyka ukraińskiego Olena Krysztalska 



\section{- KIL \\ KA \\ SŁÓW o Lwowie czasu ukraińskiej rewolucji i o symbolu ukraińskiej wolności roku 2014 - kijowskim Majdanie (relacja Rafała Kowalczyka)}

Listopad roku 2013 r. Lwów. Od razu wyczuwalne było napięcie. Grupki entuzjastycznie nastawionych ludzi, dzieci, kobiet, mężczyzn z żółto-niebieskimi kokardami, flagami ukraińskimi spotkać można było na każdym kroku. Jednak dopiero w centrum, na promenadzie Swobody, pomiędzy operą, pomnikiem Tarasa Szewczenki a pomnikiem Adama Mickiewicza, zgrupowała się najbardziej aktywna część lwowian. Widać było grupki młodzieży, starszych skupionych wokół namiotów, w których dzień i noc trwali najbardziej zagorzali zwolennicy zmian i przeciwnicy samowoli Wiktora Janukowycza. Z megafonów biły w przechodniów głosy wzywające do aktywności, do zerwania z dotychczasową biernością. Młodzież, kobiety, dzieci i mężczyźni. Przeróżne przedziały wiekowe. Potężniały z każdą chwilą. Drobne grupki, jakie pojawiały się w centrum Lwowa w południe 30 listopada stawały się coraz liczniejsze. Wraz z zachodem słońca tłum się przeobrażał. Z dziesiątków w setki, z setek w tysiące, by w końcu zająć cały lwowski „Majdan” - promenadę Swobody. Na wybudowanej tam arenie występowali społecznicy, ukraińscy artyści, rozgrzewający tłum, który co chwila wyrażał swoją niechęć do 
Janukowycza, do Putina, żądający wolności i możliwości samostanowienia. Atmosfera była przesycona emocjami. Nikt nie myślał wówczas o agresji, ale też co chwila wypowiadano, wręcz wykrzykiwano, że „my jesteśmy tu do końca”, czyli naszego zwycięstwa albo śmierci. Przekrzykiwano się tymi słowami wzajemnie. Nikt nie był w stanie naruszyć tego - hermetycznego w swej sile poglądów, wiary, przekonań - tłumu. Co chwila pozbywano się z niego tych, którzy czuli inaczej, próbowali przekrzyczeć, zdestabilizować swoim zachowaniem tłum patriotów. Nie wiem, nie zastanawiałem się wówczas nad tym, czy byli to zwolennicy Janukowycza, skaptowani kilkoma judaszowymi hrywnami, czy też upojeni alkoholem bezdomni. Zastanawia mnie natomiast co innego, czy ktokolwiek wtedy myślał, że skończy się to w taki sposób, że Janukowycz zdecyduje się na użycie siły. Podjęta przez niego decyzja o użyciu siły, broni przez specsłużby milicji, Berkut ze wschodu - wobec ludzi zgromadzonych na Majdanie - przepełniło na Ukrainie czarę goryczy. 19 stycznia cztery osoby zginęły z rąk Berkutu, który użył broni palnej. Do tego momentu nikt mimo wszystko nie oczekiwał, że Janukowycz posunie się tak daleko, że zdecyduje się przelać krew niewinnych ludzi.

Wówczas, 30 listopada, nikt o tym nawet nie myślał. Tłum ogarnął entuzjastyczny szał, kiedy na scenie pojawił się Witalij Kliczko. Burza oklasków, krzyki, wiwaty - tak witano wschodzącą gwiazdę ukraińskiego Majdanu. Jego słowa, w których nawoływał do jeszcze większej aktywności przeciw Janukowyczowi i roztaczał wizję życia w kraju pozbawionym korupcji, spowodowały niebywałe wręcz uniesienie tłumu. Nikt zresztą w tym tłumie nie myślał, że może stać się inaczej. Wiara, siła tych ludzi, zdawała się być jaskółką przyszłości. Tłum skandował i trwało to kilkadziesiąt minut. Wiwatom nie było końca...

Noc przyniosła częściowe ukojenie nastrojów, ale nie zmieniła determinacji zgromadzonych ludzi. Część z nich rozeszła się do domów, głównie kobiety i dzieci. Na straży pozostali 
mężczyźni, ale byli to głównie intelektualiści, studenci, wykładowcy, widziałem wśród nich nawet grupkę niepełnosprawnych. Wszyscy czekali na Berkut. Plotka głosiła, że do Lwowa zmierza Berkut krymski bądź doniecki. W owym tłumie entuzjastycznie nastawionych ludzi znajdowali się także milicjanci lwowscy, właściwie całkowicie bezradni. Pozbawieni broni palnej, wyposażeni tylko w pałki, pogrupowani byli w małe komanda, po trzech, czterech. Komentowali aktualną sytuację i promajdanową postawę władz Lwowa. Nikt nie wracał do domów. Przebywałem wówczas w otoczeniu muzyków, ludzi, którzy z bronią nie mieli nigdy do czynienia. Trwali tu, mimo że ich delikatne dłonie zdawały się nie pasować, być zaprzeczeniem ducha rozgrzewającego wówczas wszystkich Ukraińców we Lwowie, tych którzy nie chcieli chować się w domowych pieleszach.

Świtem nadeszły tragiczne wieści. Janukowycz zdecydował się użyć oddziały Berkutu... w Kijowie. Alea iacta est. Od godzin porannych ponownie gromadziły się potężniejące z każdą chwilą tłumy ochotników ze Lwowa. W południe do Kijowa wyruszyło kilkanaście autobusów wypełnionych głównie mężczyznami. Organizatorzy apelowali, by kobiety i dzieci pozostały w domach. Wiedzieli, że Janukowycz, watażka pełniący urząd prezydenta Ukrainy, nie cofnie się przed niczym. Zaczynał się czas walki. Walki o wszystko. Walki o wolność - Naszą, Waszą, Ich i Naszych dzieci... o Wolność Ukrainy. Walki, której końcem mogło być zwycięstwo albo śmierć.

Ruch objął całą Ukrainę, na dużą skalę Zachodnią, ale i Wschodnią, z której do Kijowa też przybywali na Majdan ochotnicy. Janukowycz swoimi działaniami zjednoczył bowiem w tym czasie Ukrainę - jego rządy przyniosły szczególnie wzrost świadomości narodowej na wschodzie. Tam również, tak jak i na zachodzie, żywo bije bowiem serce ukraińskich patriotów. Gdyby nie interwencja Władimira Putina i bezprawny, łamiący wszelkie konwencje międzynarodowe zabór Krymu, 
Ukraina dziś byłaby jednolita, zmierzając pewnie ku Zachodniej Europie, do Unii Europejskiej, w zgodzie ze swymi aspiracjami społecznymi i ekonomicznymi.

Walki na Majdanie w Kijowie były przyczyną śmierci dziesiątków ludzi. Janukowycz, wysyłając do akcji kolejne kohorty Berkutu, nie cofnął się bowiem przed niczym. Śmierć na Majdanie, porwania, morderstwa, gwałty, zastraszanie rodzin uczestników zrywu były w styczniu i lutym 2014 r. na Ukrainie na porządku dziennym. Ukraińcy nie ugięli się jednak. Obalili Janukowycza. Plany Putina legły w gruzach... zaskoczony sytuacją, fiaskiem planów odbudowy imperium, w którym Ukraina miała być ważnym elementem jego Unii Euroazjatyckiej - zdecydował później o użyciu sił na Krymie i o destabilizacji w obszarach najbardziej prorosyjskich, w donieckim i ługańskim rejonie, wysyłając tam broń, sprzęt, najemników, instruktorów.

\section{Majdan kijowski - takim się stał...}

Dziś Majdan to symbol przemian, walki o Wolność, walki narodu z systemem znienawidzonej władzy na niespotykaną po II wojnie światowej skalę, walki zakończonej zwycięstwem. Jeszcze niedawno na każdym skwerze Majdanu - Majdanu Nezałeżnosti - widoczne były ślady walk, pocisków, jakimi strzelał do protestujących ludzi Berkut. Zdjęcia poległych przyciągały uwagę przechodniów. Wyrwane fragmenty kostki brukowej, spalone samochody, opony, konstrukcje metalowe chroniące przed nacierającymi milicjantami. Jeszcze niedawno tak wyglądał Majdan, pełno na nim było namiotów, a w nich... ludzie, którzy cały czas żyją Majdanem... Oblepione hasłami namioty, zaimprowizowane polowe muzea prezentujące użytą tam broń, pociski i zdjęcia... dziesiątki zdjęć... W blasku letniego słońca 2014 r. Ukraińcy, odświętnie ubrani, kobiety, mężczyźni, dzie- 
ci, odwiedzali miejsca, gdzie jeszcze w styczniu, lutym tegoż roku ginęli za nich wszystkich patrioci, by po kilku miesiącach kijowskie rodziny mogły swobodnie spacerować po deptaku. Ukraina zawdzięcza dużo Majdanowi - Ukraińcy pokazali wówczas, jak silna jest w nich wola walki, determinacja, by obalić znienawidzonego prorosyjskiego watażkę - Janukowycza, siła, która pozwoliła im wyrwać się z okowów rosyjskiego, putinowskiego żelaznego uścisku, ponownie wtłaczającego ich w system zależności od Moskwy. Dziś Majdan uosabia wolę przemian, walki w Kijowie, ale i walki o jedność narodu, państwa w rejonach na wschodzie - w Doniecku, Ługańsku, które z rozkazu rosyjskiego satrapy spływają krwią braci - tych z zachodu i tych ze wschodu Ukrainy. 



\section{BIB \\ - LIO \\ GRA \\ FIA}

Akcja „Wisła”. Dokumenty, oprac. E. Misiło, Warszawa 1993.

Baluk W., Kształtowanie systemu partyjnego Ukrainy w okresie transformacji ustrojowej (1987-2004), Wrocław 2006.

Borowik I., Odbudowywanie pamięci. Przemiany religijne w Środkowo-

Wschodniej Europie po upadku komunizmu, Kraków 2000.

Bruski J. J., Petlurowcy. Centrum Państwowe Ukraińskiej Republiki

Ludowej na wychodźstwie (1919-1924), Kraków 2004.

Bryc A., Cele polityki zagranicznej Federacji Rosyjskiej, Torun 2005.

Bunt pokolenia. Rozmowy z intelektualistami ukrainskimi, rozm. i kom. B. Berdyszowska, O. Hnatiuk, Lublin 2000.

Burant S. R., Stosunki polsko-ukraińskie a idea strategicznego partnerstwa, Warszawa 2000.

Chojnowski A., Ukraina, Warszawa 1997.

Chojnowski A., Bruski J. J., Ukraina - Historia państw świata w XX wieku, Warszawa 2006.

Donaj Ł., Polityka bezpieczeństwa niepodległej Ukrainy 1991-2004, Łódź 2005.

Drozd R., Ukraińska Powstańcza Armia. Dokumenty, struktury, Warszawa 1998. 
Dylematy rozwoju Ukrainy, red. L. Hurska-Kowalczyk, Szczecin 2011. Eberhardt P., Przemiany narodowościowe na Ukrainie XX wieku, Warszawa 1994.

Fedorowicz K., Ukraina w polskiej polityce wschodniej w latach 19891999, Poznań 2004.

Felsztinski J., Stanczew M., Trzecia wojna światowa? Bitwa o Ukrainę, Poznań 2015.

Gibas-Krzak D., Ukraina. Między Rosją a Polską, Toruń 2006.

Gill W., Gill N., Stosunki Polskiz Ukrainą w latach 1989-1993, Toruń 2002. Horska N., Aktywność narodowa mniejszości rosyjskiej na Ukrainie (1991-2004), Łysomice 2009.

Hrycak J., Historia Ukrainy 1772-1999. Narodziny nowoczesnego narodu, Lublin 2000.

Hryciuk G., Stoćkyj J., Studia nad demografia historyczną i sytuacja religijna Ukrainy, Lublin 2000.

Huntington S. P., Zderzenie cywilizacji i nowy kształt ładu światowego, Warszawa 1998.

Jakowenko N., Historia Ukrainy do 1795 roku, Warszawa 2011.

Jakowenko N., Historia Ukrainy od czasów najdawniejszych do końca XVIII wieku, Lublin 2000.

Jędraszczyk K., Strategiczne partnerstwo ukraińsko-polskie. Polska w polityce niepodległej Ukrainy, Poznań 2010.

Kapuśniak T., Ukraina jako obszar wpływów międzynarodowych po zimnej wojnie, Warszawa-Lublin 2008.

Konieczna J., Polska-Ukraina. Wzajemny wizerunek, Warszawa 2001.

Kost P., Ukraina wobec Unii Europejskiej 1991-2010, Toruń 2012.

Kowalczyk R., Szanse i zagrożenia Unii Europejskiej w przeobrażającej się zglobalizowanej gospodarce początków XXI wieku, УкраїнаПольща: діалог культур в контексті євроінтеграцї, t. 1, Запоріжжя 2014.

Kowalczyk R., Ukraina-Polska-Rosja poczatku XX wieku. Na styku Zachodu i Wschodu, Богдан Лепкий у полікультурномудискурсі Європи та Америки, Тернопіль 2012. 
Kowalczyk R., Uстоки проиесса глобализачии капиталистической экономики развивающихся стран перед первой мировой войной. Трансформація національних моделей економічного розвитку в умовах глобалізації, Київ 2013.

Kowalczyk R., Кавказ - близько далеко, відомий і невідомий Грузія, „Обєктив” 2014, № 5-6.

Kozakiewicz J., Rosja w polityce niepodległej Ukrainy, Warszawa 1999.

Kozłowski K., Iluzje rewolucji. Rewolucja róż, rewolucja pomarańczowa, rewolucja tulipanów, Warszawa 2011.

Krotofil M., Ukraińska Armia Halicka 1918-1920. Organizacja, uzbrojenie, wyposażenie i wartość bojowa sił zbrojnych Zachodnio-Ukraińskiej Republiki Ludowej, Toruń 2002.

Krząstek T., Ukraina, Warszawa 2002.

Kuspys P., Wspótczesne stosunki polsko-ukraińskie 1991-20o8. Polityka, gospodarka, wojsko, sektor pozarządowy, Kraków 2009.

Kutrzeba T., Wyprawa kijowska, Warszawa 1937.

Lelonek A., Mniejszość rosyjska i rosyjskojęzyczna na Ukrainie, Warszawa 2011.

Madera A., Ukraina na rozdrożu. Między Rosją a Europa, Rzeszów 2000.

Malak K., Polityka bezpieczeństwa narodowego Ukrainy, Warszawa 1999.

Mędrzecki W., Niemiecka interwencja militarna na Ukrainie w 1918 roku, Warszawa 2000.

Mironowicz E., Polityka zagraniczna Ukrainy 1990-2010, Białystok 2012.

Motyka G., Antypolska Akcja OUN-UPA 1943-1944. Fakty i interpretacje, Warszawa 2002.

Motyka G., Od rzezi wołyńskiej do akcji Wisła, Kraków 2011.

Motyka G., Ukraińska partyzantka 1942-1960, Warszawa 2006.

Motyka G., Wnuk R., Pany i rezuny. Wspótpraca AK-WiN i UPA 19451947, Warszawa 1997.

Olchawa M., Imperialna rozgrywka. Ukraina w geopolitycznej strategii Stanów Zjednoczonych, Kraków 2009.

Olejarz T., Ukraina między dysfunkcjonalną demokracją a nieskonsolidowanym autorytaryzmem, Lublin 2011. 
Olszański T., Historia Ukrainy XX w., Warszawa 1994.

Olszański T., Trud niepodległości. Ukraina na przełomie tysiącleci, Kraków 2003.

Pawluczuk W., Ukraina. Polityka i mistyka, Kraków 1998.

Petlura S., Naczelny Ataman. Wybór pism, red. i wstęp. M. Popowycz i G. Hryciuk, Wrocław 2012.

Podhorodecki L., Sicz Zaporoska, Warszawa 1978.

Podhorodecki L., Zarys dziejów Ukrainy, t. 1-3, Warszawa 1976.

Podsiadłowicz M., Polityka bezpieczeństwa Ukrainy, Warszawa 2004. Poliszczuk W., Ideologia nacjonalizmu ukraińskiego, Toronto 1996.

Polityka zagraniczna Federacji Rosyjskiej. Wybrane aspekty stosunków z Polską, Ukraina i Białorusia, red. L. Zyblikiewicz, M. Czajkowski, P. Bajor, Kraków 2010.

Polska i Ukraina. Próba analizy systemu politycznego, red. S. Sulowski, Warszawa 2011.

Polska i Ukraina. Sojusz 1920 roku i jego następstwa, red. i wst. Z. Karpus, W. Rezmer, E. Wiszka, Toruń 1997.

Polska i Ukraina po II wojnie światowej, red. W. Bonusiak, Rzeszów 1998. "Pomarańczowa rewolucja” - szansa dla ukraińskiej transformacji politycznej, red. A. Furier, Szczecin 2006.

Potocki R., Idea restytucji Ukraińskiej Republiki Ludowej (1920-1939), Lublin 1999.

Przeobrażenia ustrojowe w republikach dawnego ZSRR, red. E. Zieliński, Warszawa 1993.

Repatriacja czy deportacja. Przesiedlenie Ukraińców z Polski do USSR 1944-1946, red. E. Misiło, Warszawa 1996-1999, t. 1-2.

Riabczuk M., Dwie Ukrainy, Wrocław 2004.

Riabczuk M., Od Małorosji do Ukrainy, Kraków 2002.

Serczyk W., Historia Ukrainy, Wrocław 2001.

Serczyk W., Na dalekiej Ukrainie. Dzieje Kozaczyzny do 1648 roku, Kraków 1984.

Siemaszko W., Ludobójstwo dokonane przez nacjonalistów ukraińskich na ludności polskiej Wołynia (1939-1945), t. 1-2, Warszawa 2000. 
Stosunki polsko-ukraińskie. Historia i pamięć, red. J. Marszałek-Kawa i Z. Karpus, Toruń 2008.

Stosunki polsko-ukraińskie w latach 1939-2004, red. B. Grott, Warszawa 2004.

Strońska A., Dopóki milczy Ukraina, Warszawa 1998.

Stryjek T., Ukraińska idea narodowa okresu międzywojennego. Analiza wybranych koncepcji, Wrocław 2000.

Szajdek S., Polsko-ukraiński sojusz polityczno-wojskowy w 1920 roku, Warszawa 2005.

Szeptycki A., Ukraina wobec Rosji. Studium zależności, Warszawa 2013.

Torzecki R., Kwestia ukraińska w polityce III Rzeszy (1933-1945), Warszawa 1972.

Ukraina 1956-1968, oprac. I. Koszeliwiec, Paryż 1969.

Ukraina w stosunkach międzynarodowych, red. M. Pietraś, T. Kapuśniak, Lublin 2007.

Ukraińska myśl polityczna w XX wieku. Materiały z międzynarodowej konferencji naukowej zorganizowanej przez Instytut Historii Uniwersytetu Jagiellońskiego i Fundację św. Włodzimierza Chrzciciela Rusi Kijowskiej w Krakowie 28-30 maja 199o, red. M. Pułaski, Kraków 1993.

Wilson A., Ukraińcy, Warszawa 2004.

Wiszka E., Systemy polityczne Ukrainy, Toruń 2007.

Wojciechowski M., Pomarańczowy majdan, Warszawa 2006.

Zieliński E., System konstytucyjny Ukrainy, Warszawa 2007.

Żurawski vel Grajewski P., Sprawa ukraińska na konferencji pokojowej w Paryżu w roku 1919, Warszawa 1995. 

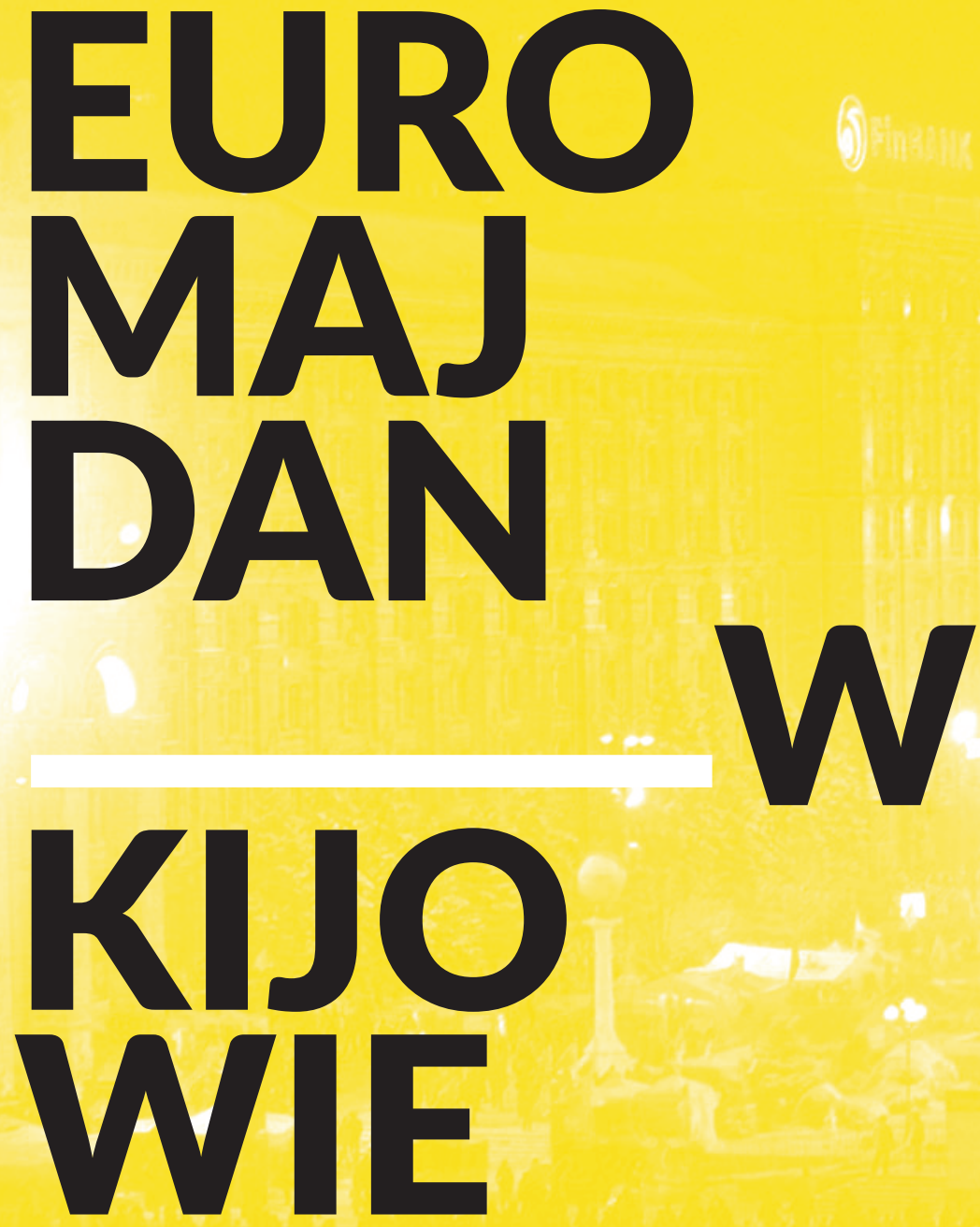
CZAS CHWAŁY 


\section{UKRAINA W NAMIOTACH}

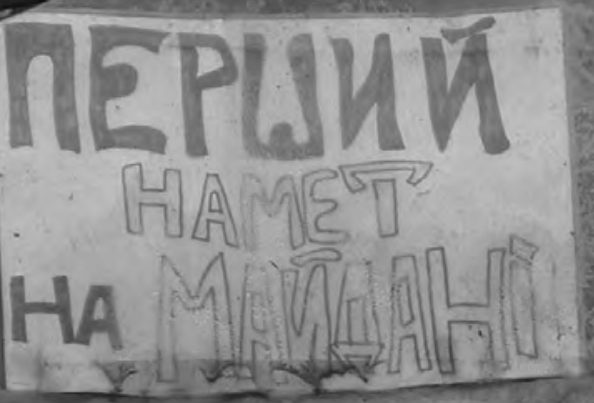

\section{YKPAIICLKI BUEA:}

$3 A$

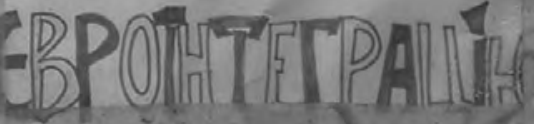

Pierwszy namiot na Majdanie Niezależności rozbity przez protestujących jeszcze $w$ listopadzie 2013 r.
Na stronie obok:

Najstarsze „namioty”

Majdanu - prowizoryczne, poruszające dowody determinacji i... zdesperowania

demonstrantów. 


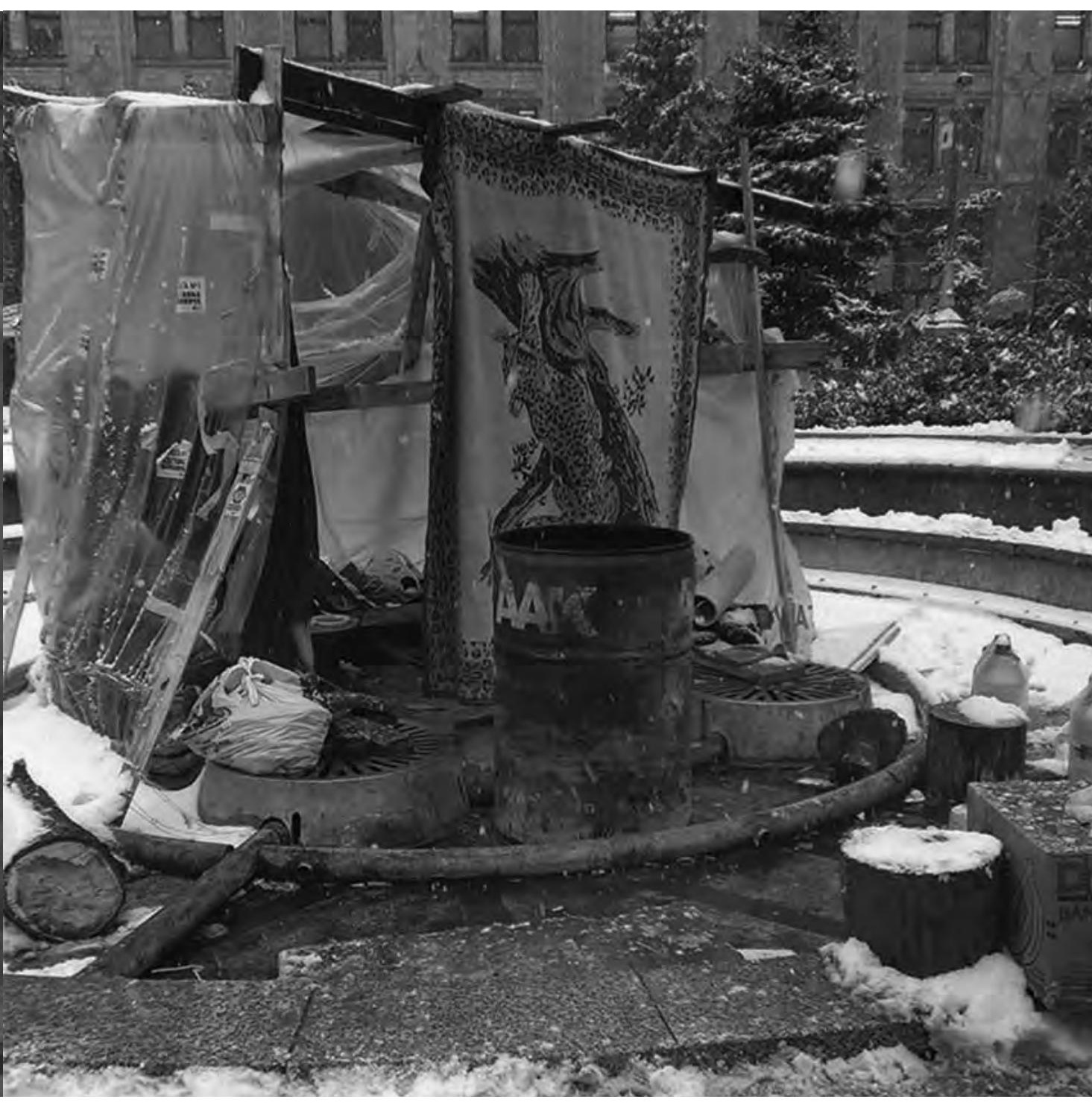




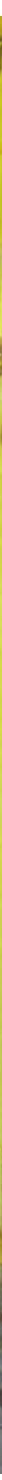




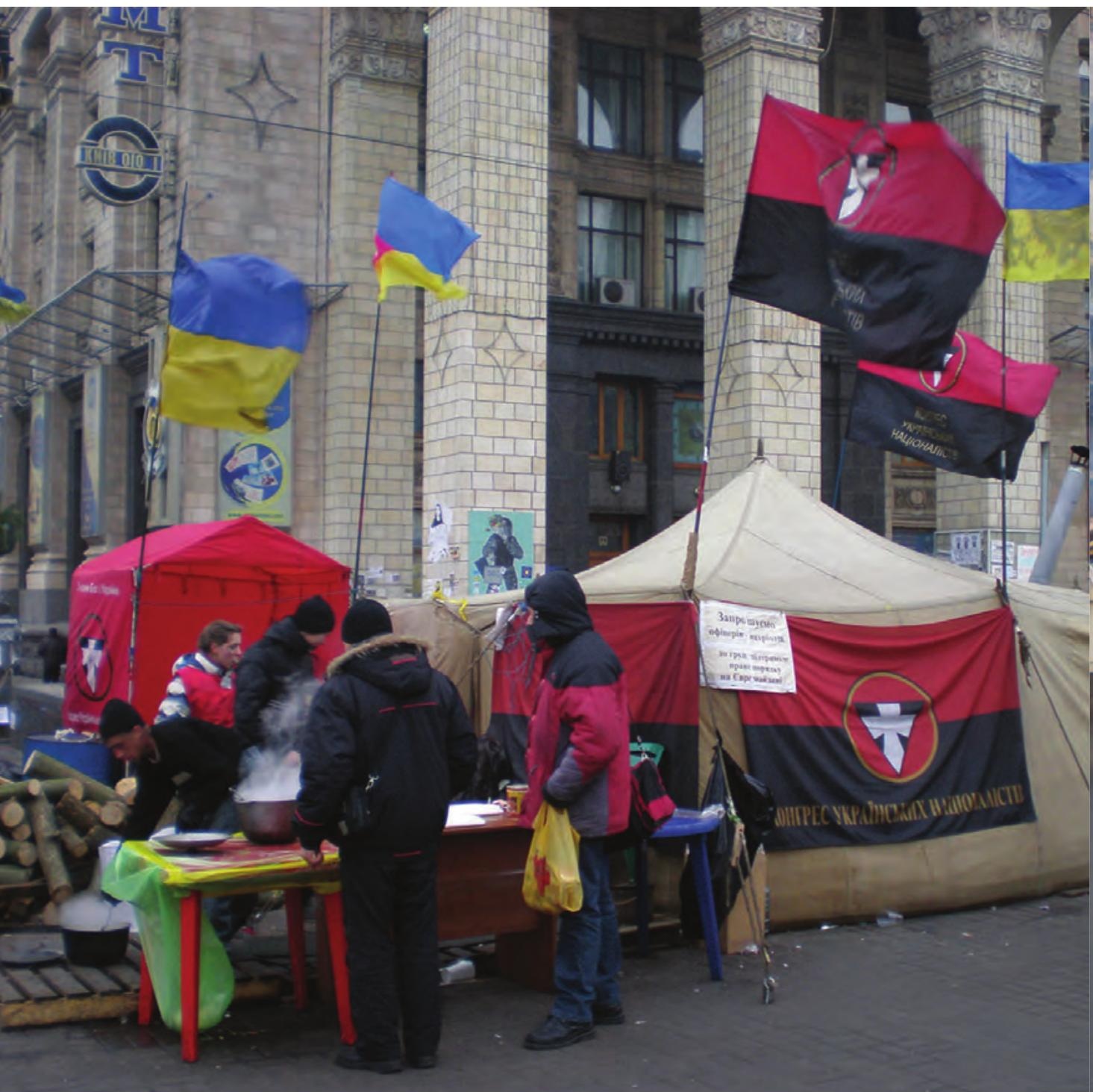

Namiot Kongresu Ukraińskich Narodowców (Nacjonalistów) - antyrosyjskiej, ale i eurosceptycznej organizacji politycznej - na skrzyżowaniu ulic Chreszczatyk i Mychajliwska.
Na stronie obok:

Namioty Narodowego

Ruchu Ukrainy na ul.

Chreszczatyk przy Placu Niepodległości. 


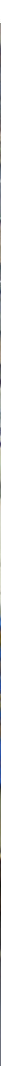




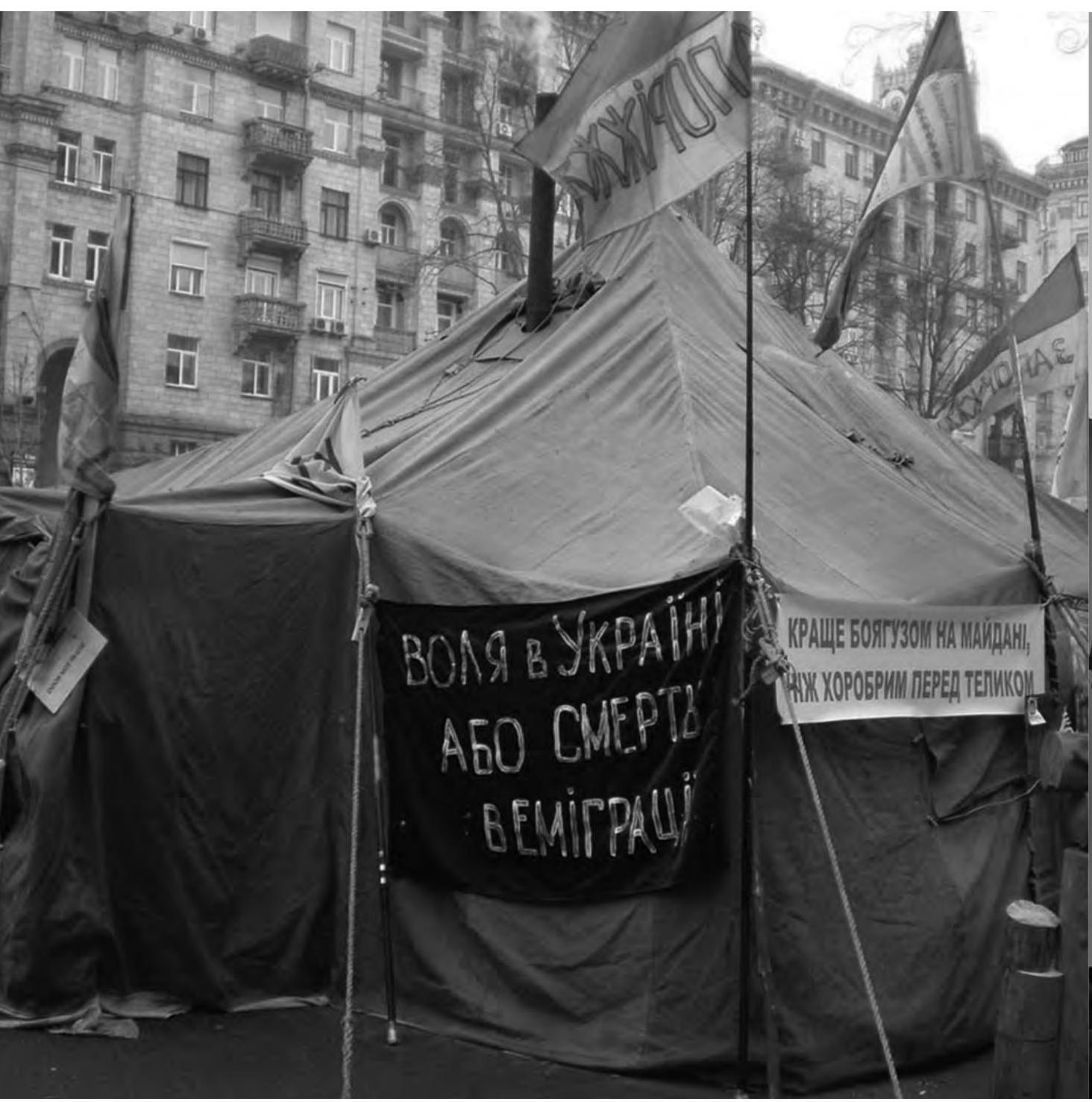

Budujący dla uczestników protestu na Majdanie dowód poparcia dla ich sprawy przez rodaków z innych regionów Ukrainy. Namioty protestujących z miasta Zaporoże...
Na stronie obok:

...Doniecka, zaprzeczające mitowi prorosyjskiego i separatystycznego 


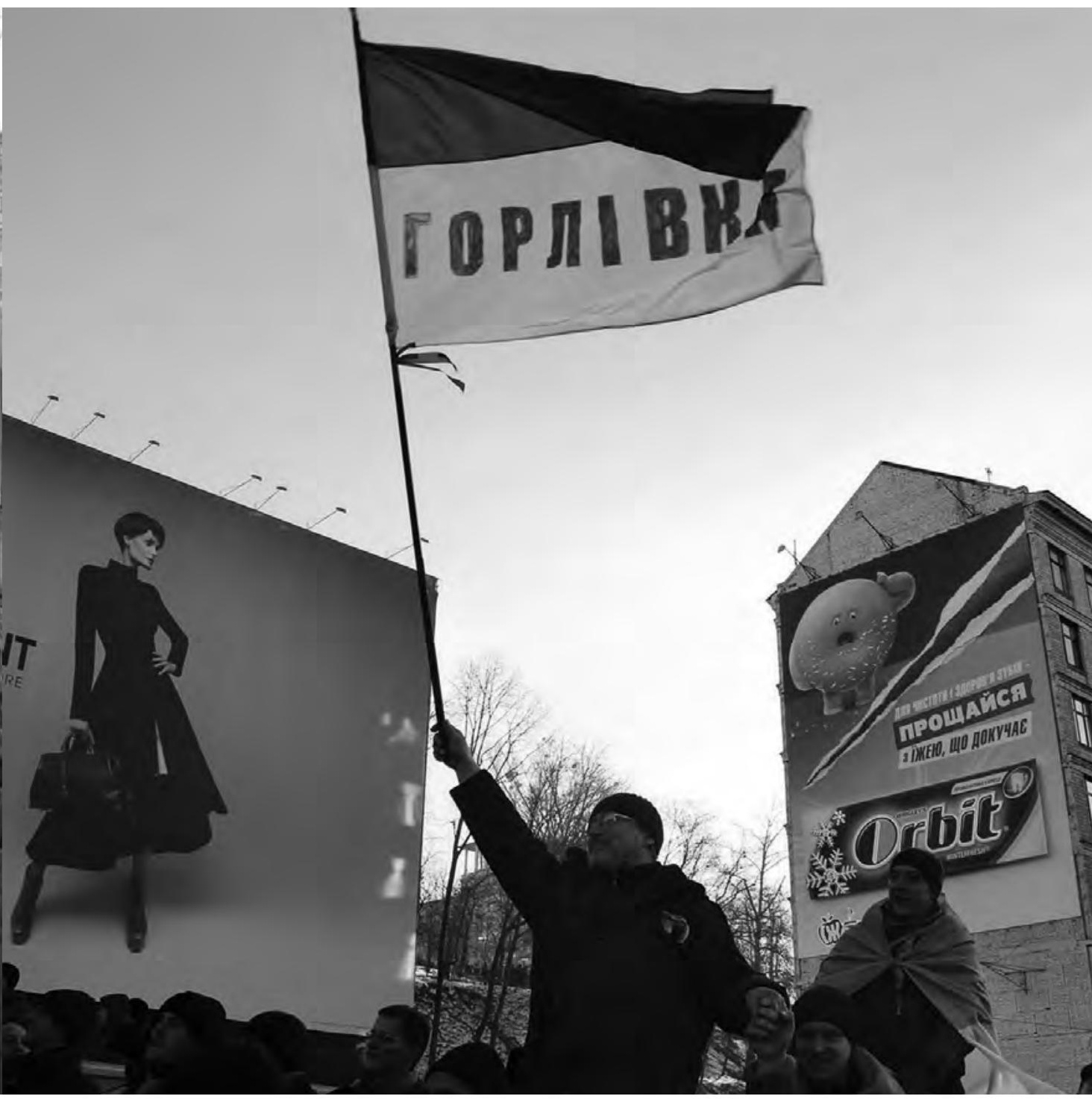

nastawienia ludności wschodniej Ukrainy... 


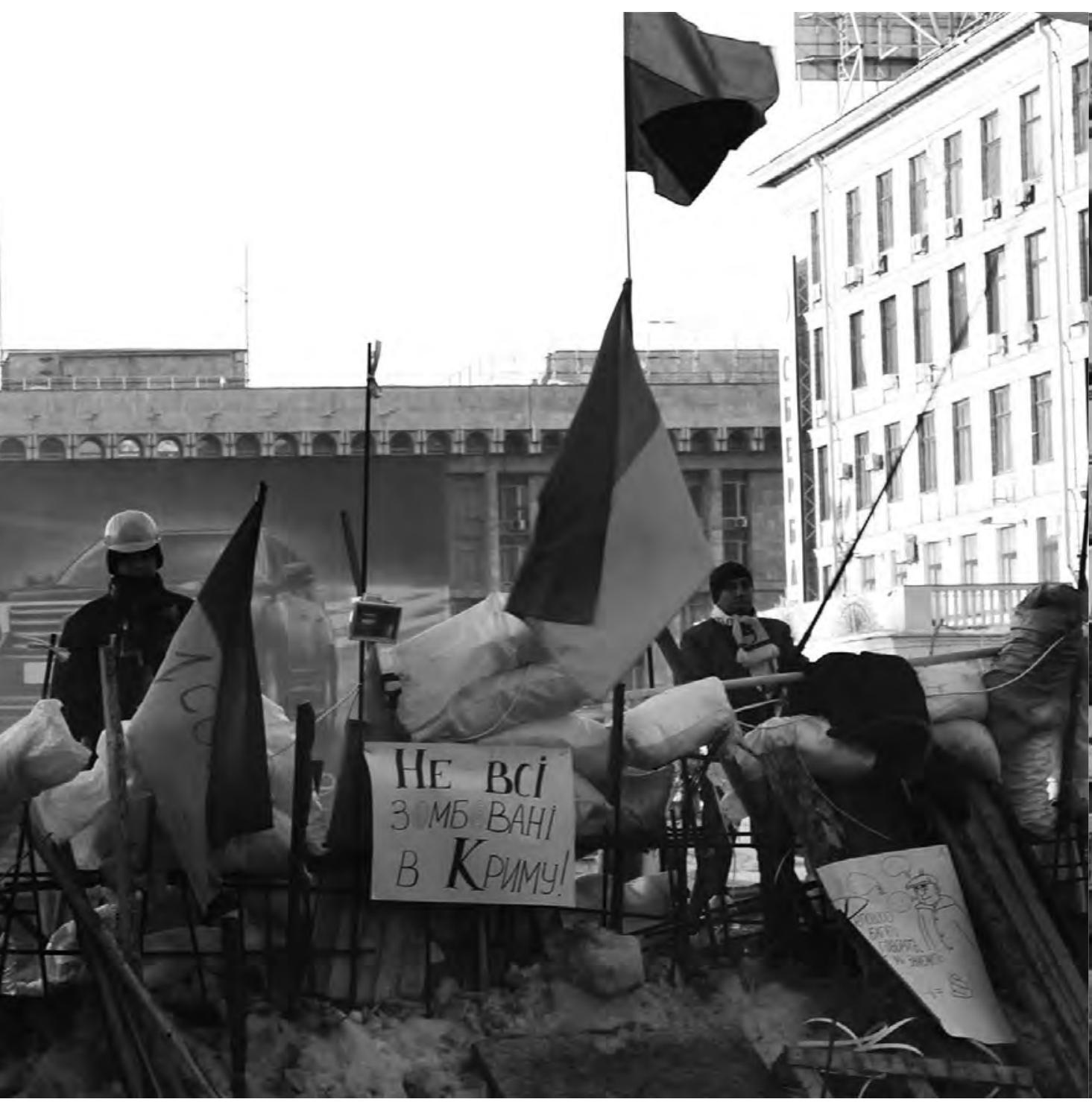

...i Krymu, zajętego przez „zielone ludziki” Putina u schyłku lutego 2014 r., rzekomo przy pełnym, entuzjastycznym poparciu miejscowej ludności dla rosyjskich najeźdźców.

\section{Na stronie obok:}

Fragment tzw. Alei Polan z nazwami miejscowości, których mieszkańcy poparli kijowski Euromajdan. 


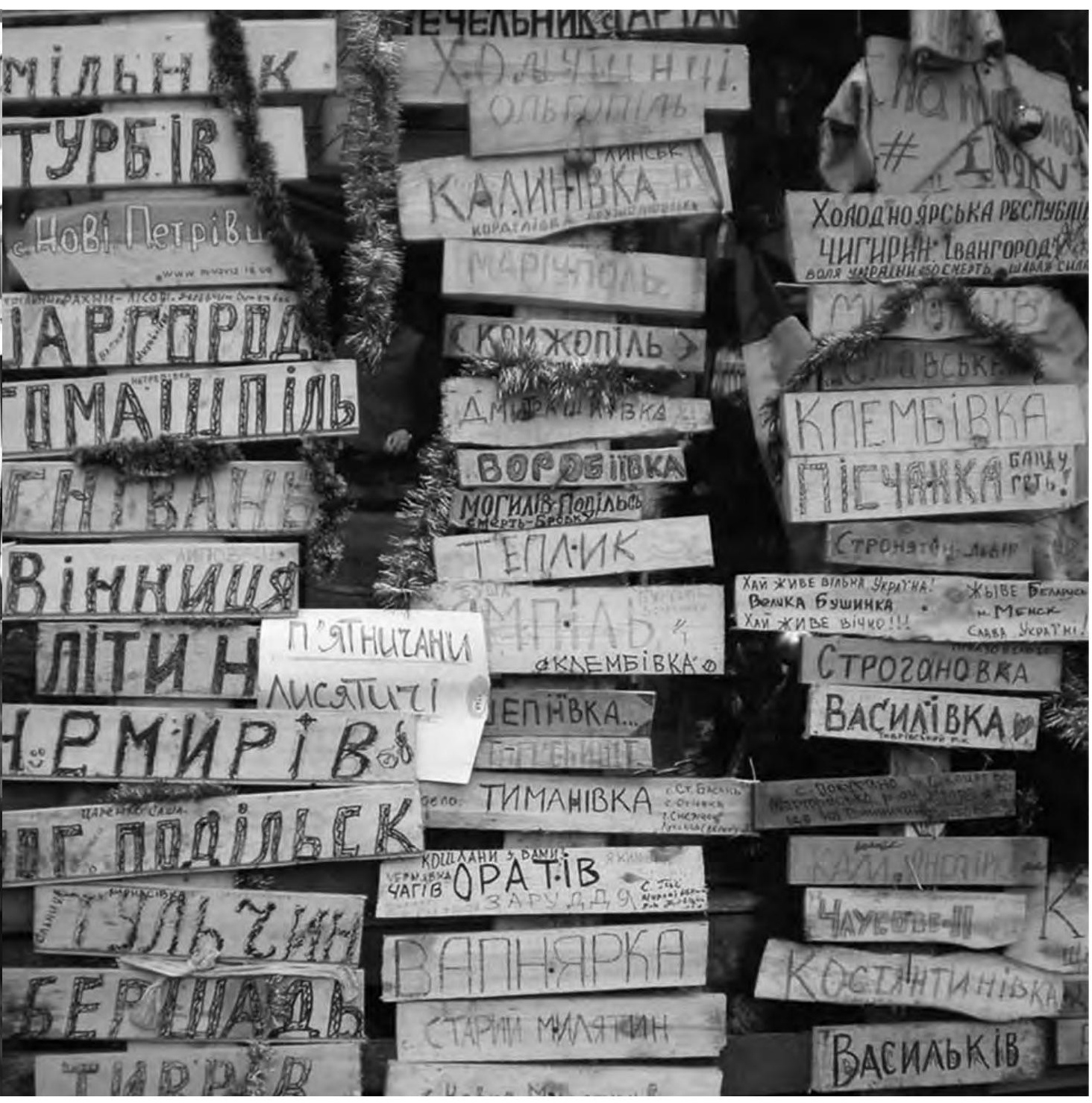




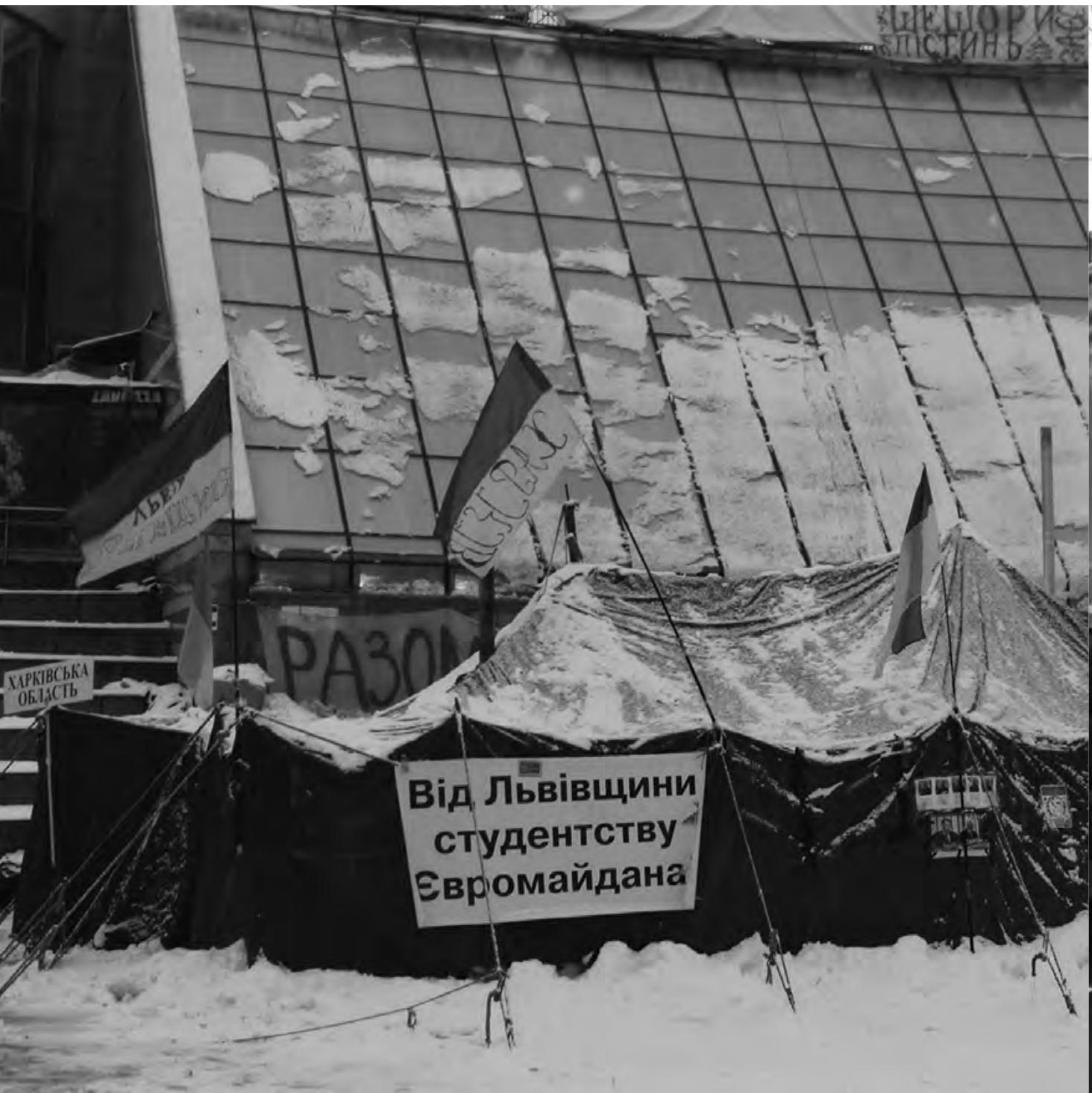

Namioty studentów popierających

Euromajdan.

\section{Na stronie obok:}

Manifestanci na Placu Niepodległości bardzo szybko organizowali się, tworząc „struktury władzy” Maj- danu i wyspecjalizowane komórki mające ułatwić egzystencję "majdanowców". Sprawnie działały służby medyczne... 


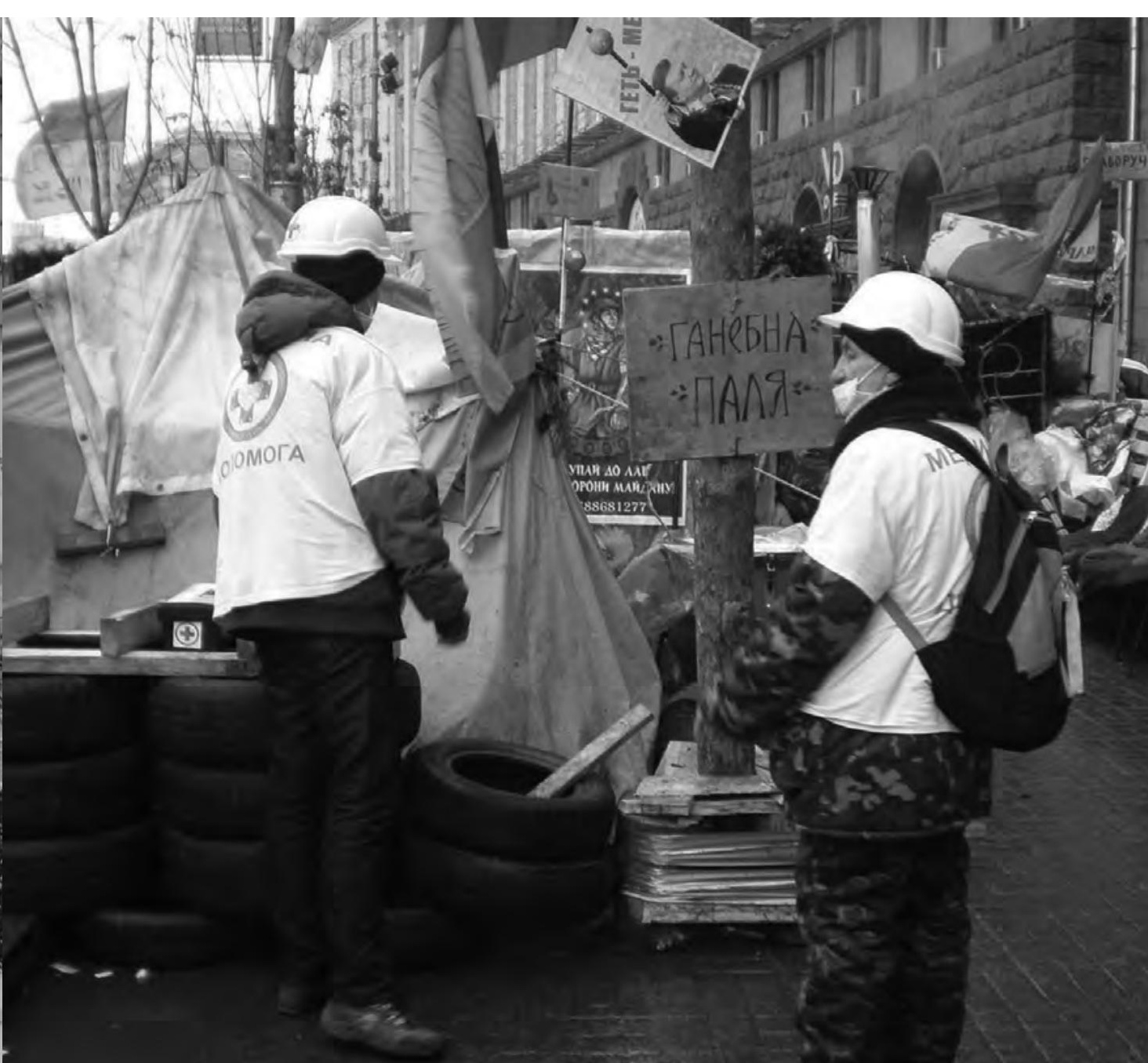




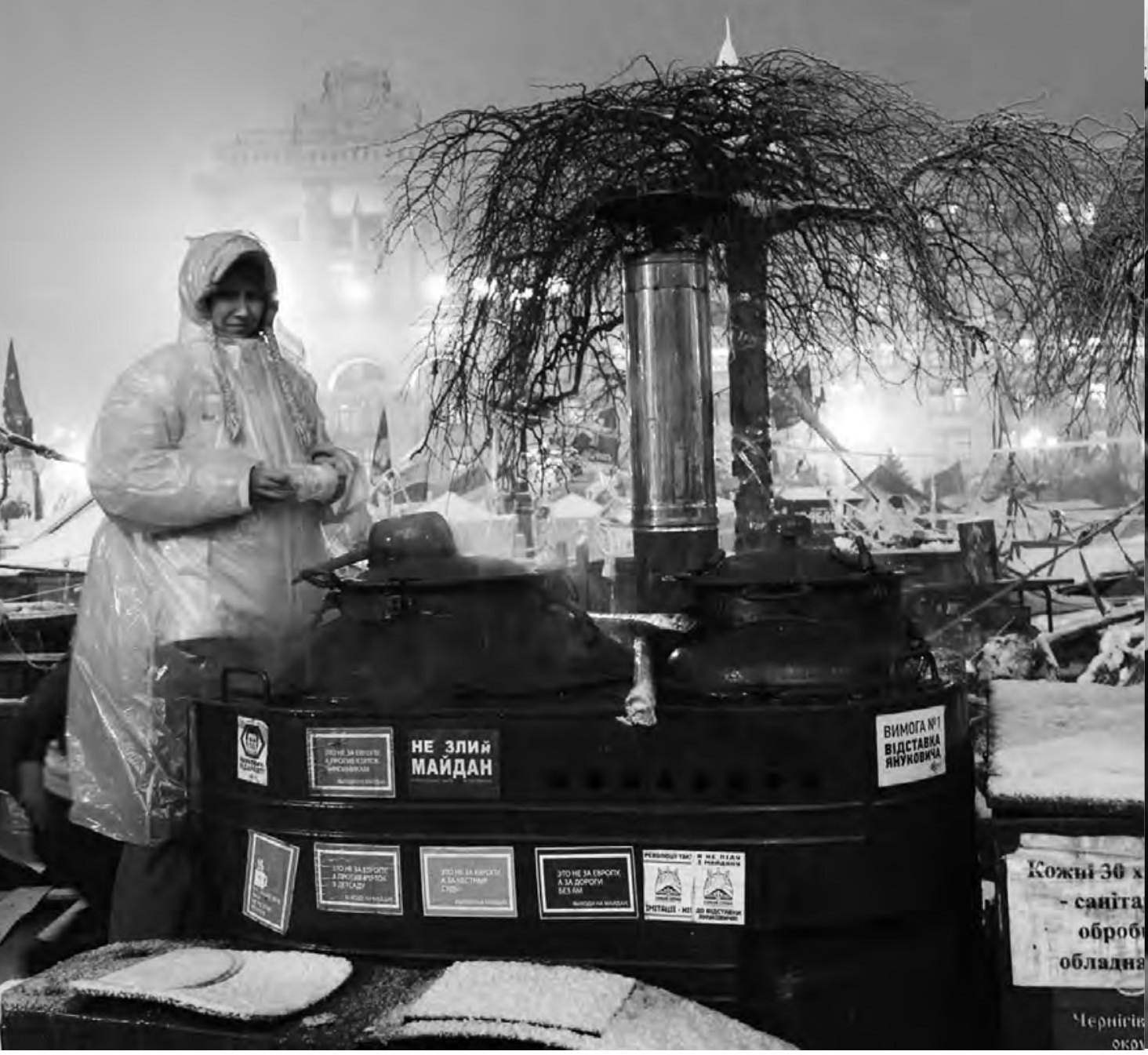

...i kuchnie polowe Majdanu. Ciepły posiłek, herbata, kawa - bohaterowie też bywają głodni i zmarznięci...
Na stronie obok:

Plac Niepodległości odwiedzali - chcąc urozmaicić i umilić życie „maj- danowców" - muzycy-amatorzy. 


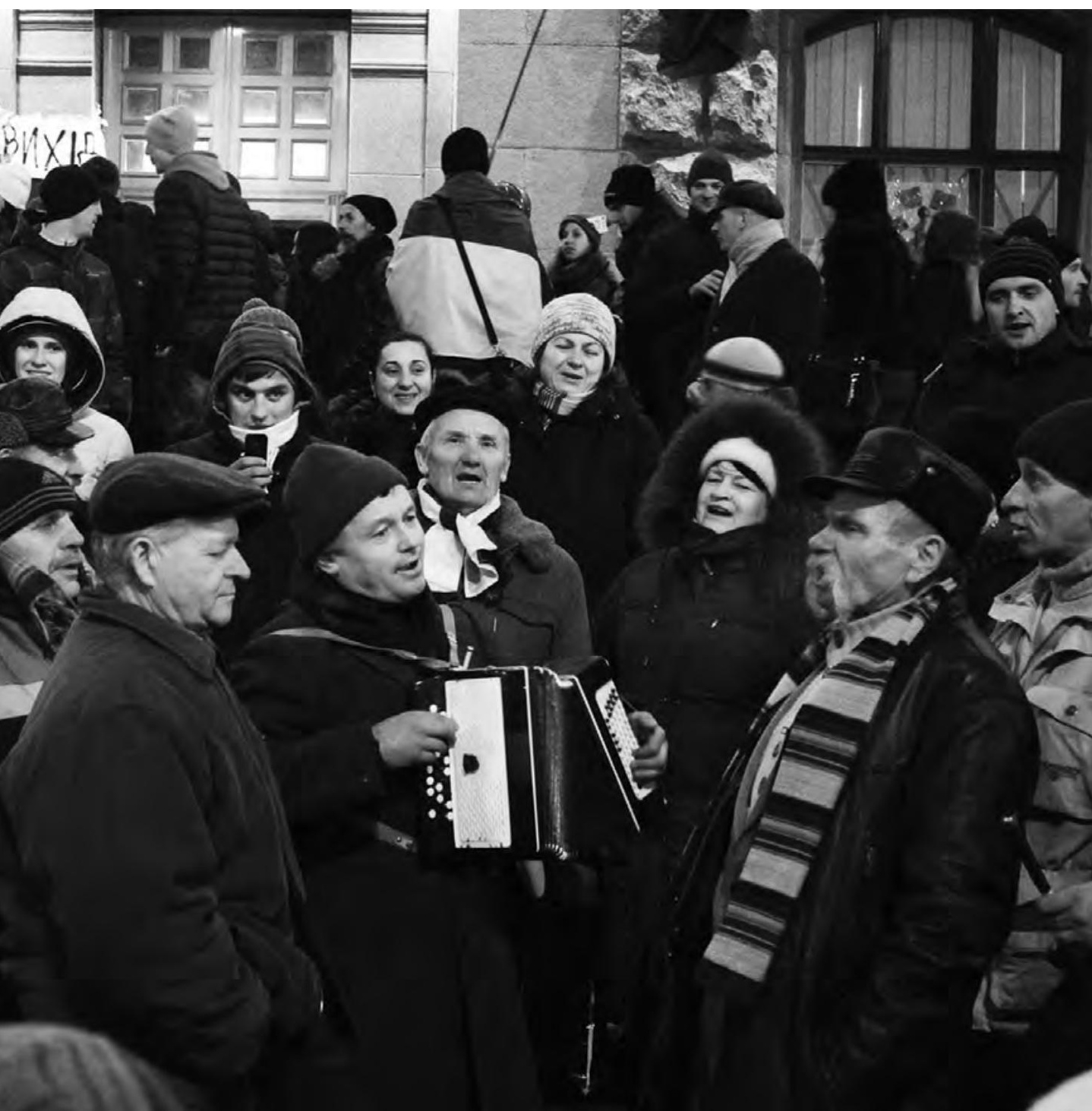




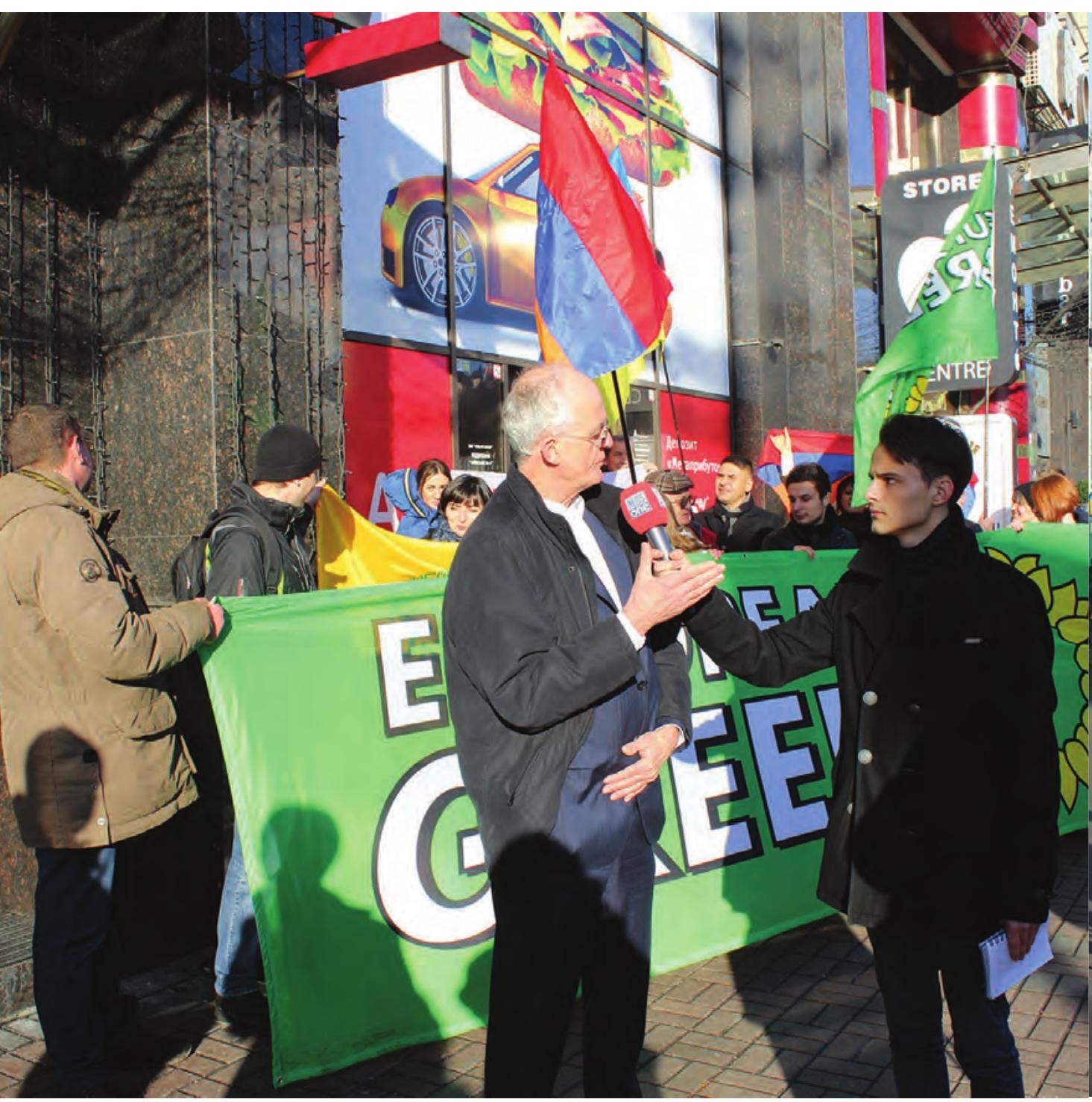

Codziennymi gośćmi na Placu byli przedstawiciele lokalnych, niezależnych mediów oraz zachodni dziennikarze, relacjo- nujący dla swoich stacji przebieg dramatycznych wydarzeń.
Na stronie obok:

Oblicza Majdanu... „Ty arko przymierza między dawnymi i młodszymi laty. W tobie lud składa broń 


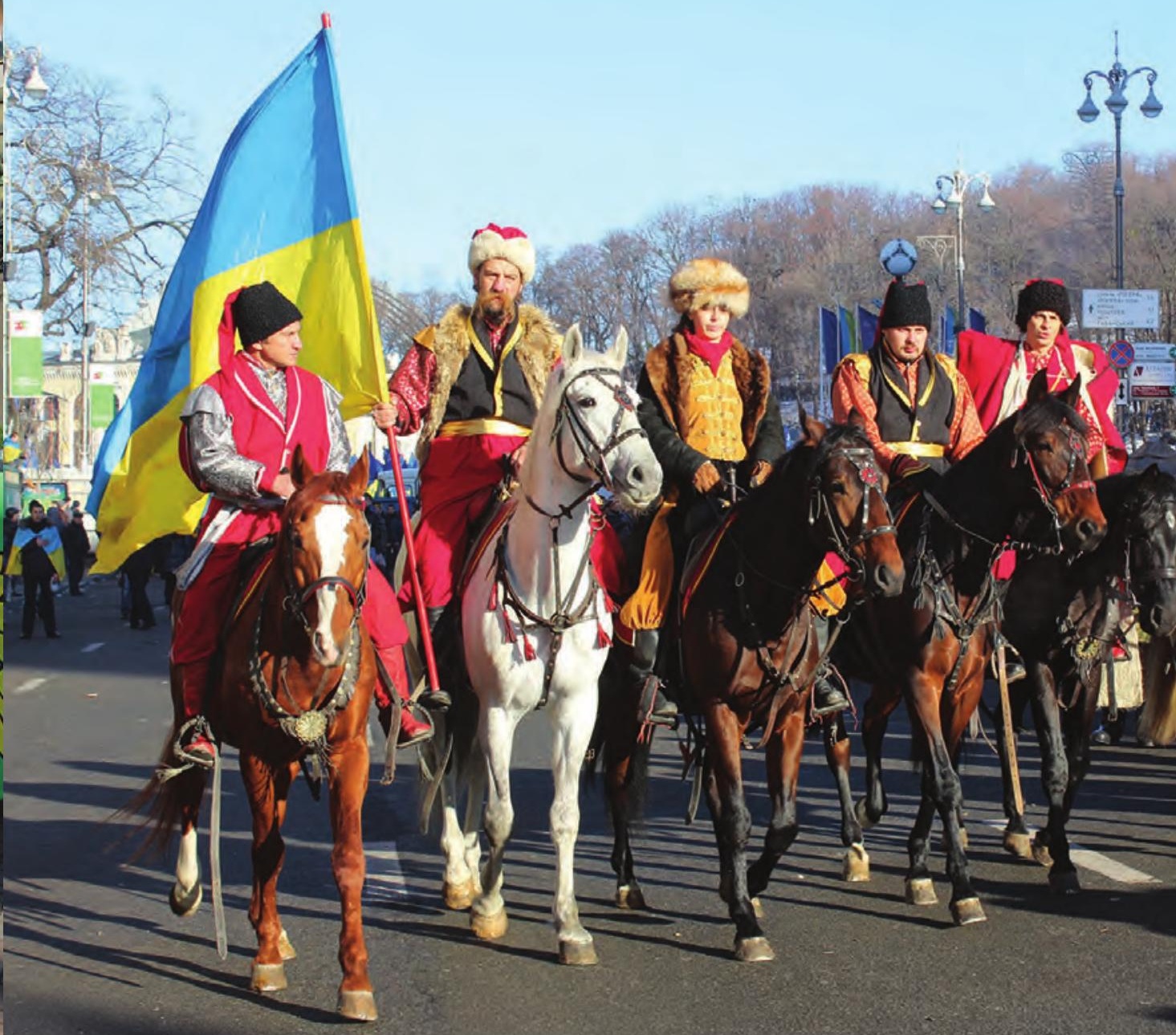

swego rycerza, swych

myśli przędzę i swych

uczuć kwiaty" - w wersji

ukraińskiej. 


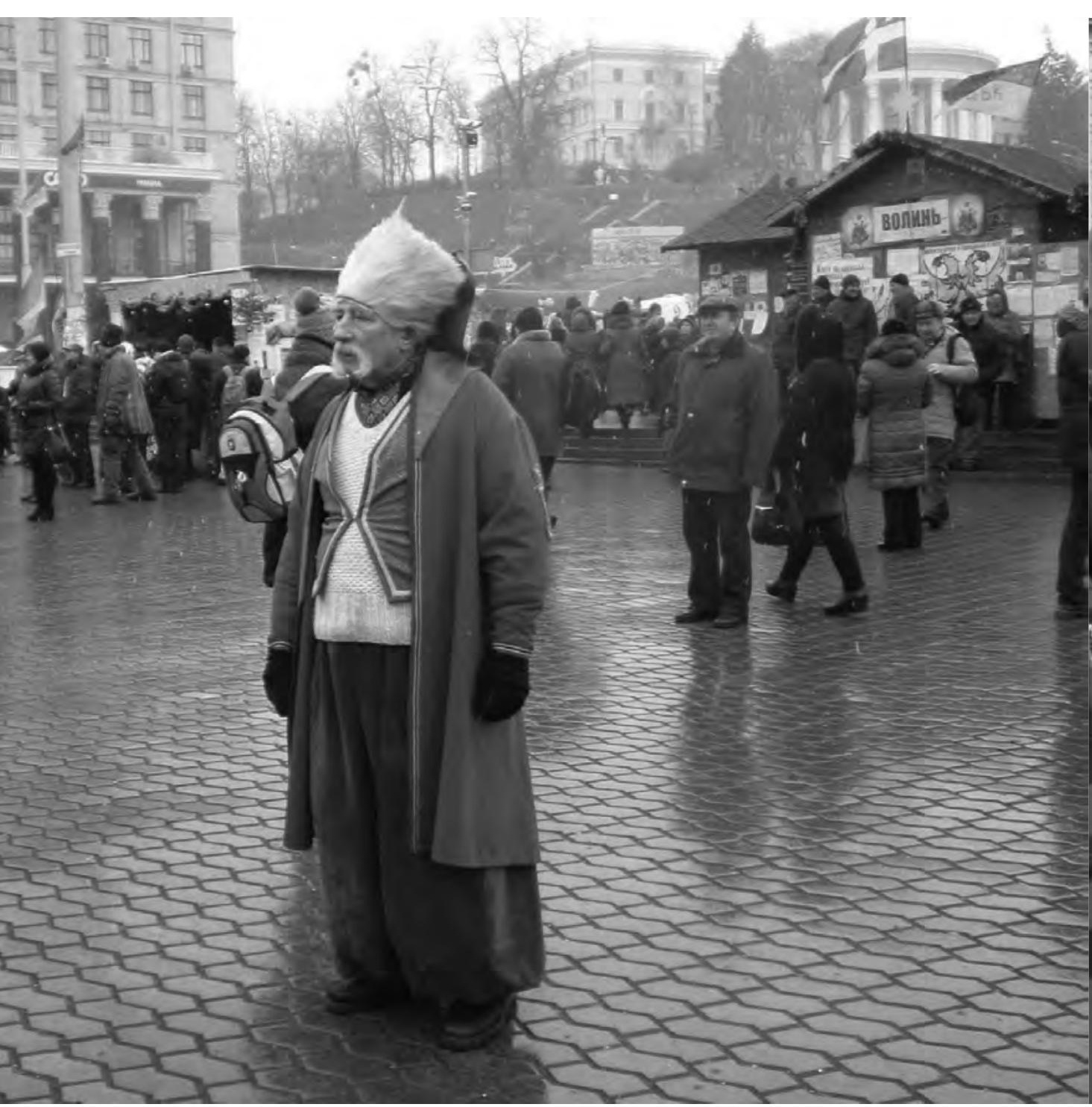

Oblicza Majdanu.

Wehikułem czasu wprost

z kozackiego taboru, czyli ukraińska moda na historię.

\section{Na stronie obok:}

Oblicza Majdanu. Powrót do teraźniejszości. 


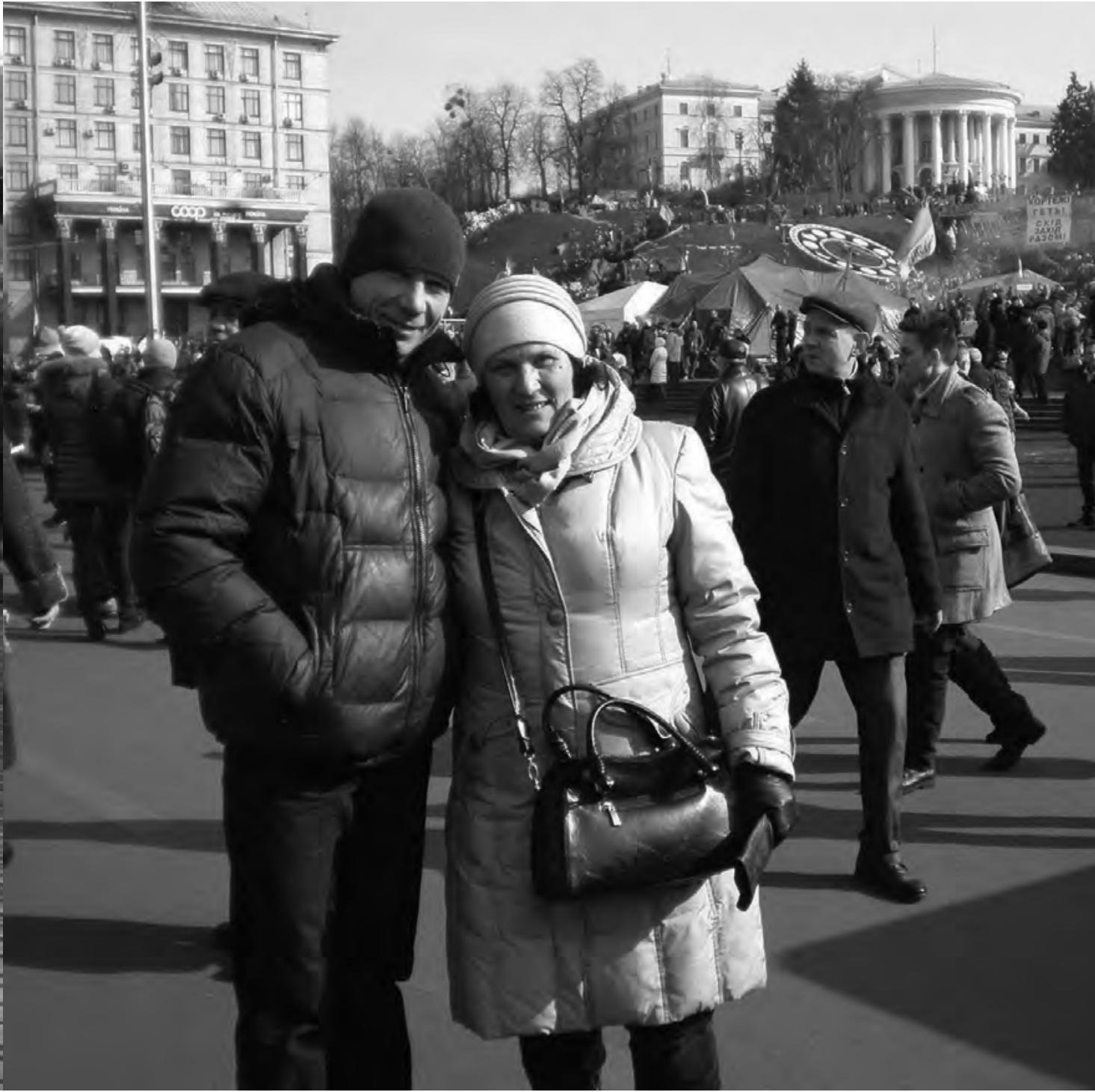




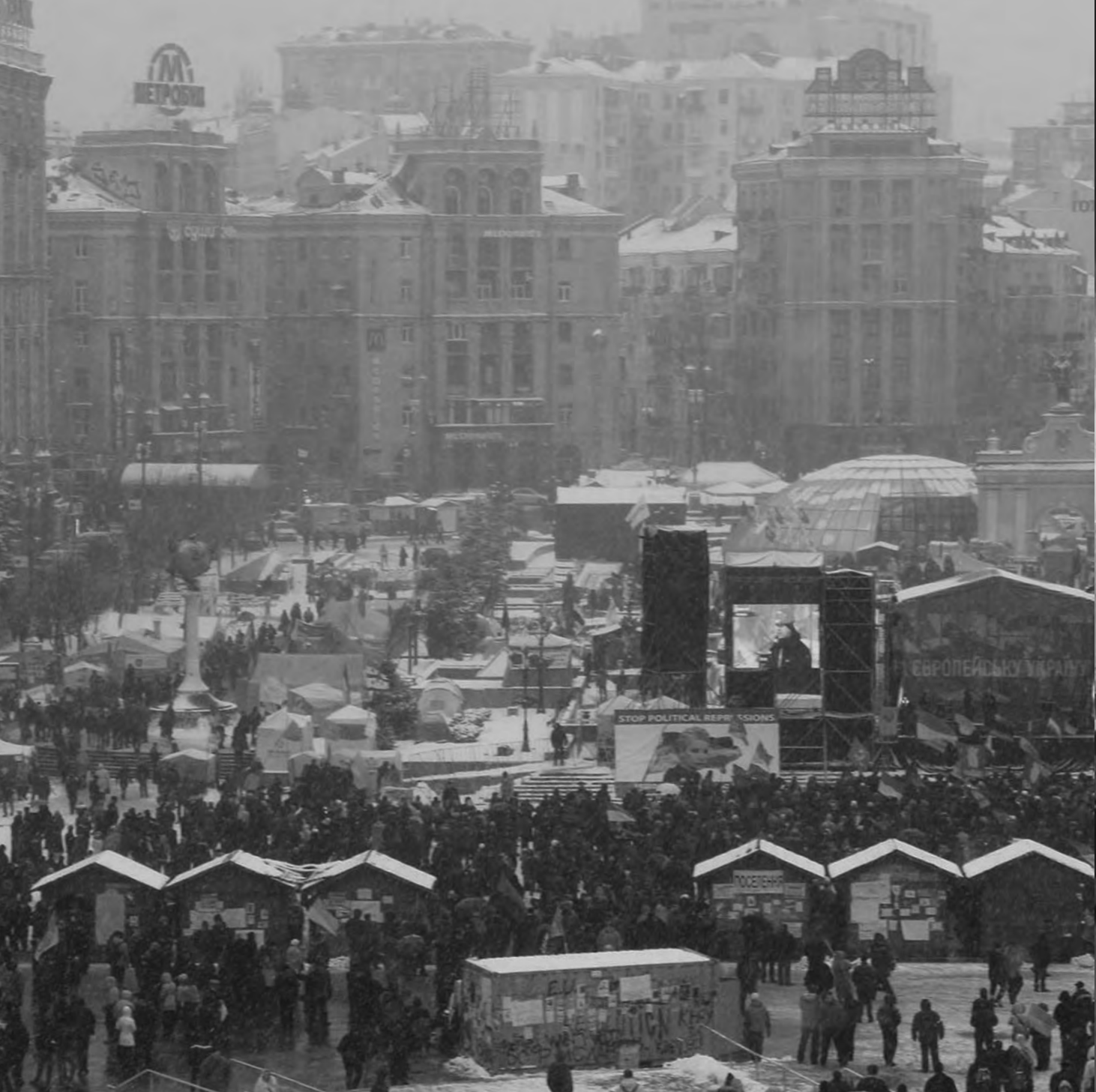

$\mathrm{Na}$ Euromajdanie w ciągu dnia...
Na stronie obok:

i nocą tętniło życie. Plac był nie tylko miejscem protestu, ale także jednym, wielkim punktem informacyjnym; współczesną agorą, wrzącą od politycznych narad, sporów i negocjacji. 
Gininane

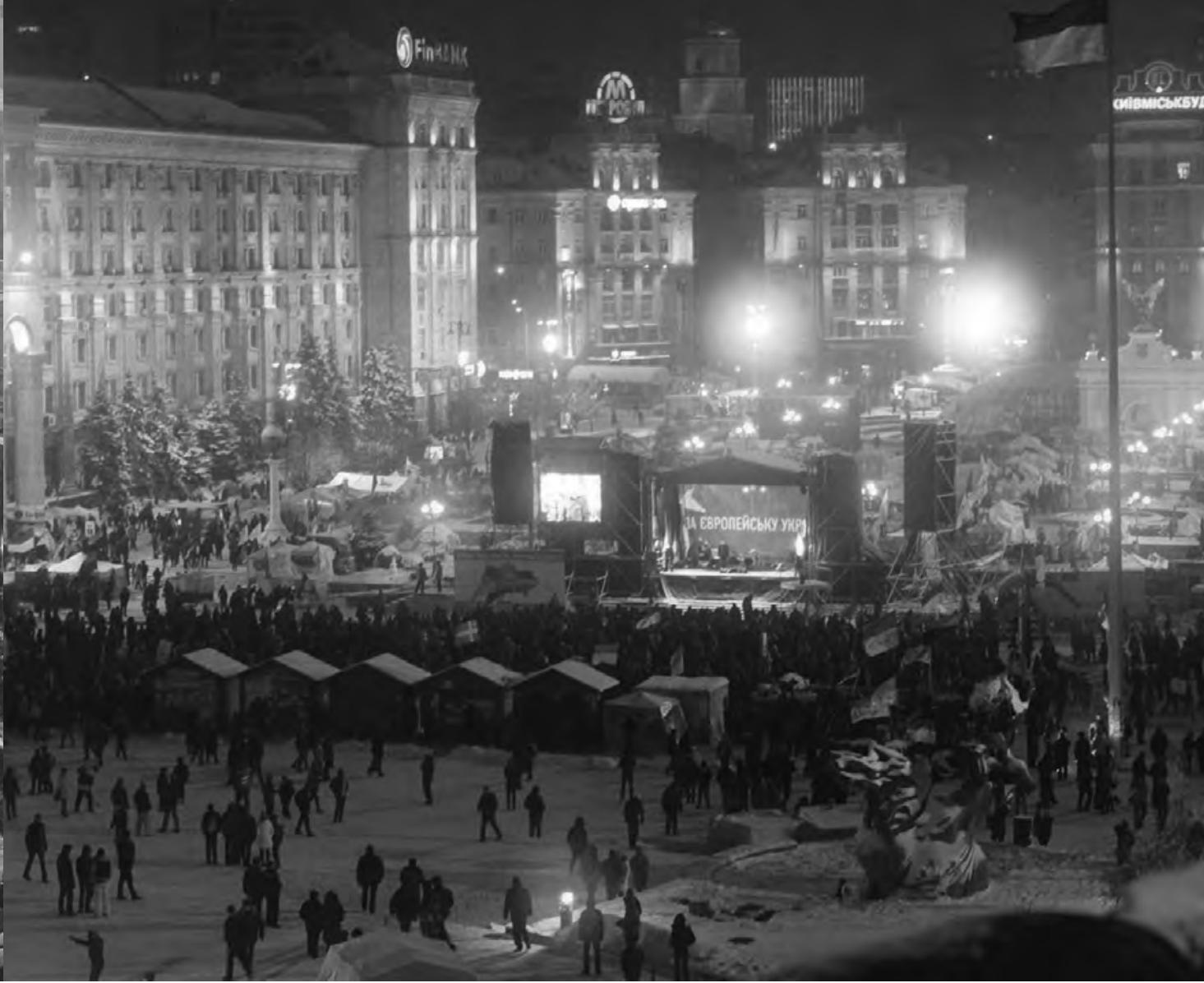




\section{SYMBOLE EUROMAJDANU}

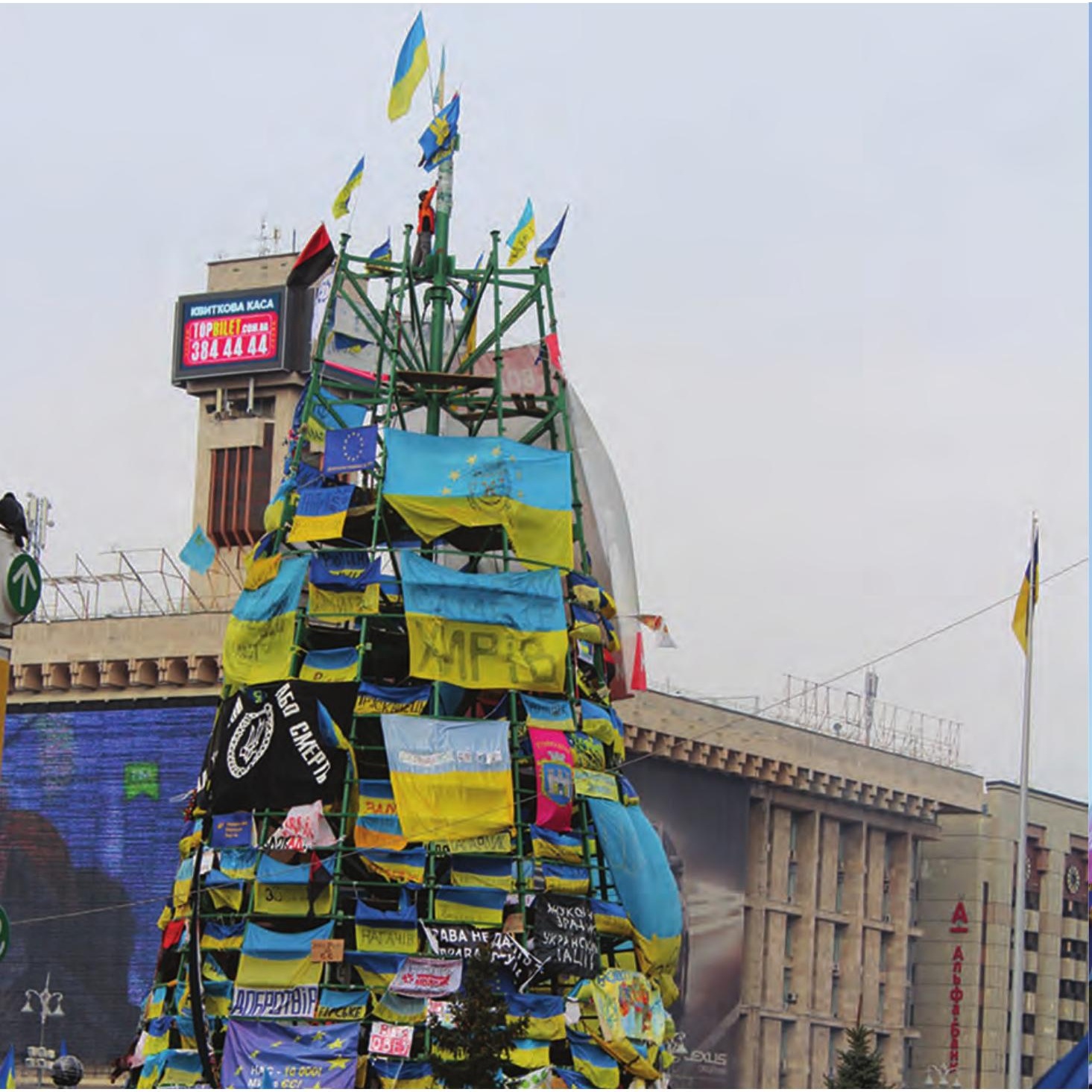

A. Najbardziej chyba znany z licznych przekazów medialnych symbol kijowskiego protestu, po- pularne miejsce spotkań demonstrantów i odwiedzających Plac Niepodległości...

\section{Na stronie obok:}

...czyli słynna „polityczna” choinka Euromajdanu, ozdobiona przez jej twórców hasłami i deklaracjami. 


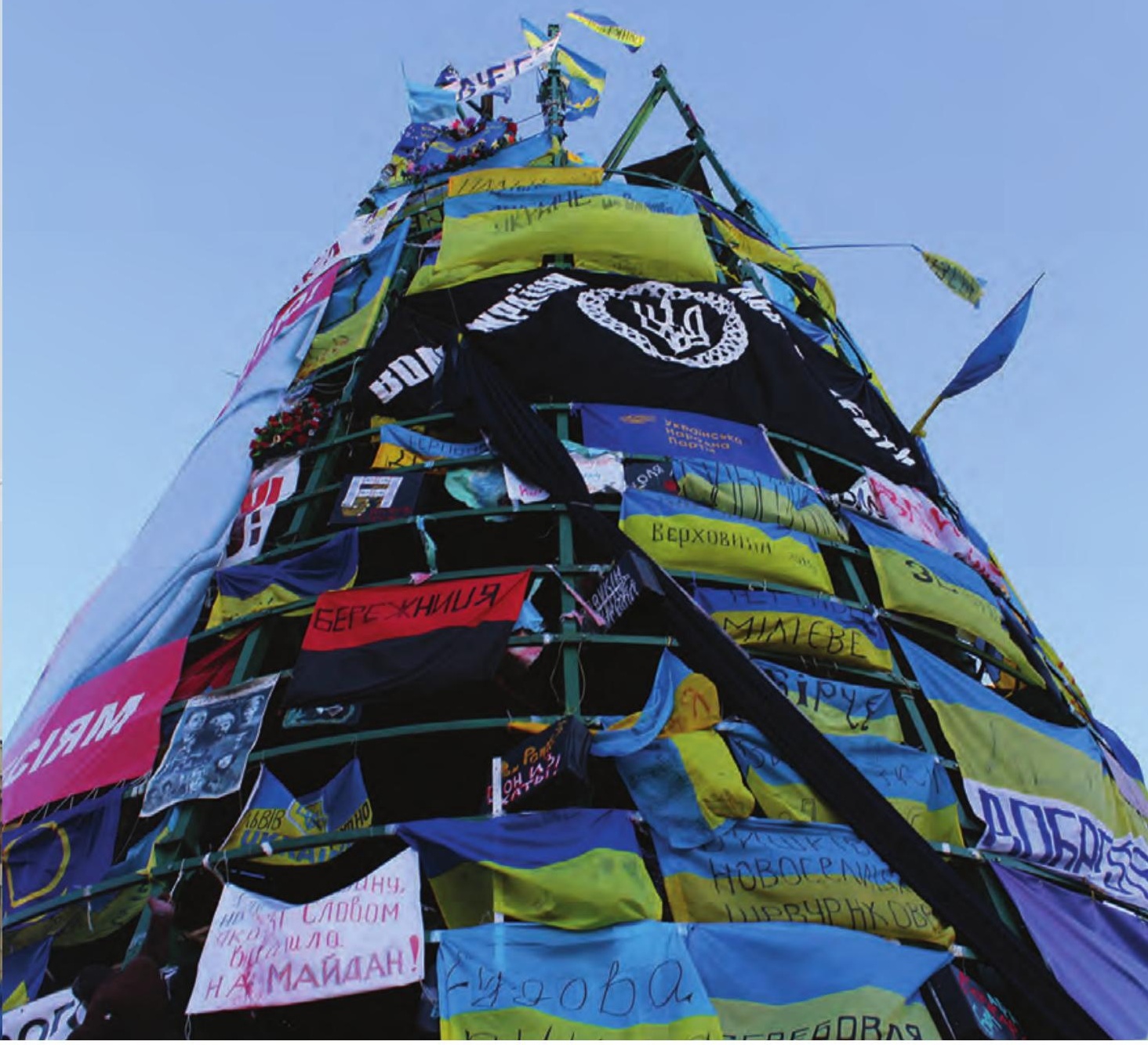




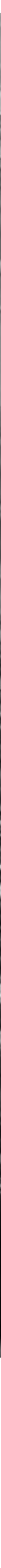




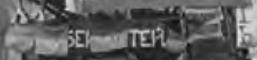

Q 1 (1)

\section{(1)} 5.

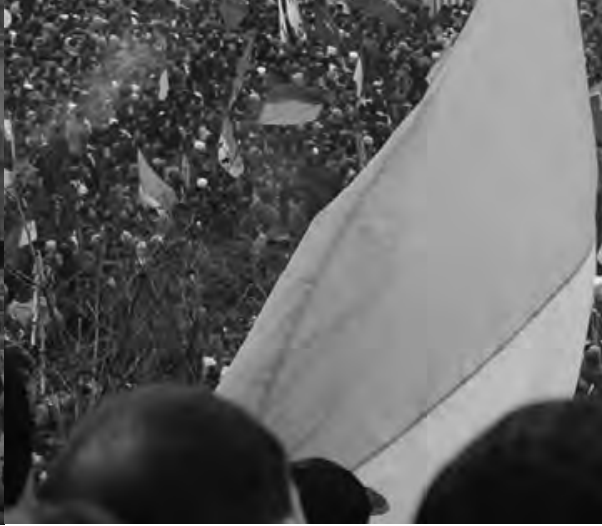

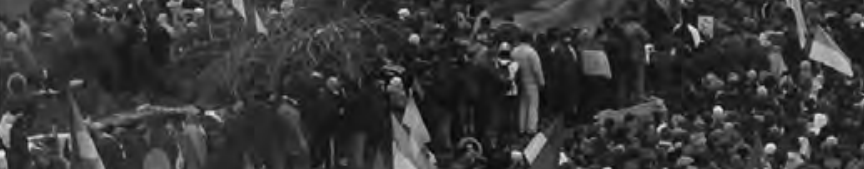

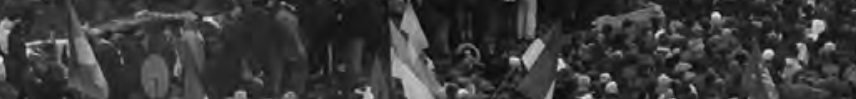

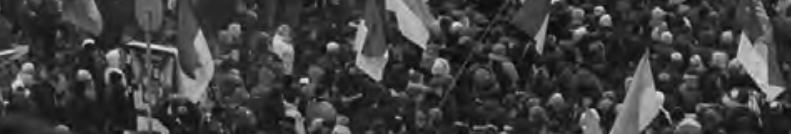
a. $x^{2}+\sin ^{2}$ 


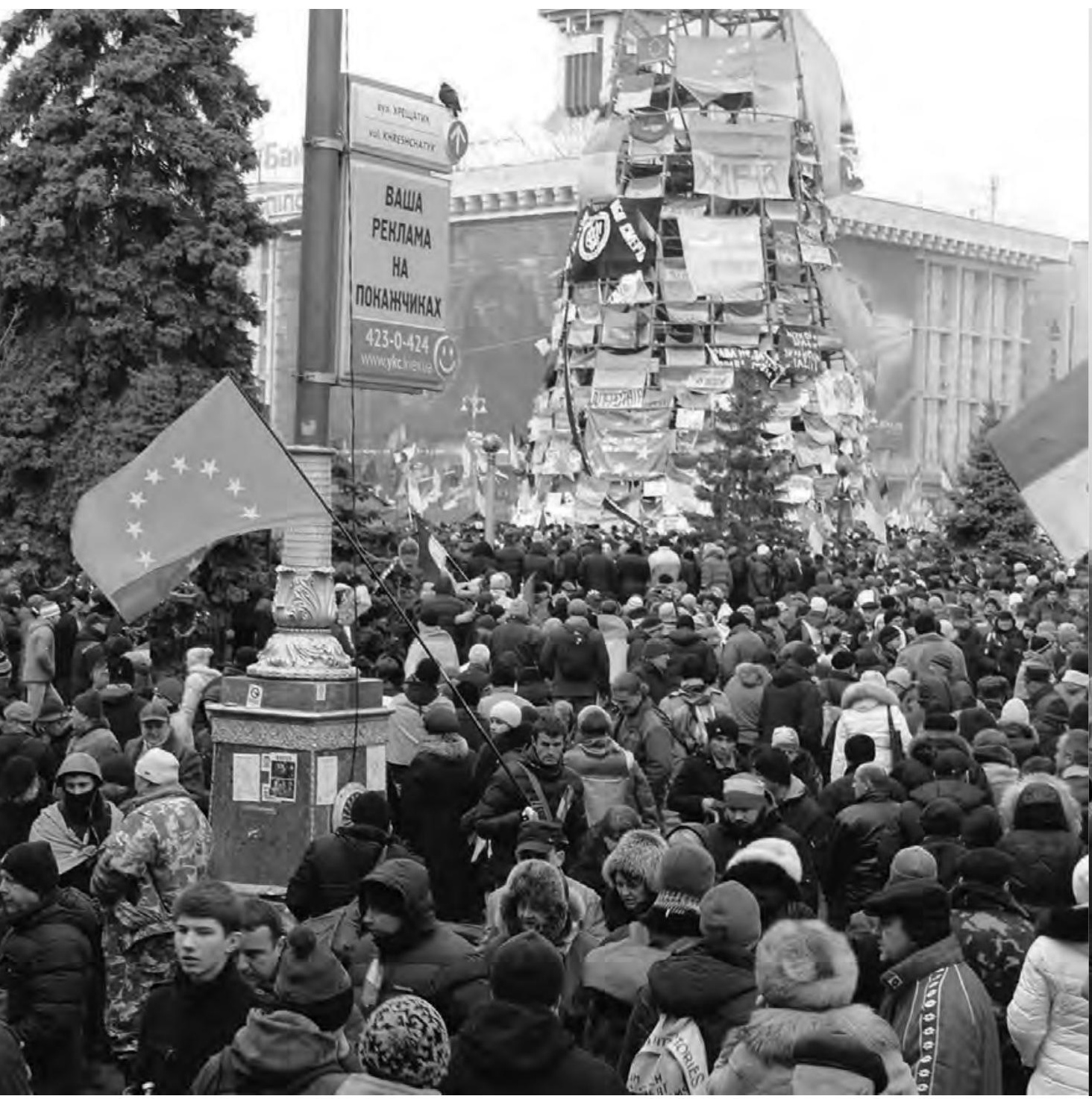

...podczas organizowanych na Placu Niepodległości politycznych wieców, manifestacji, pochodów...

\section{Na stronie obok:} ...i Świąt Noworocznych. 


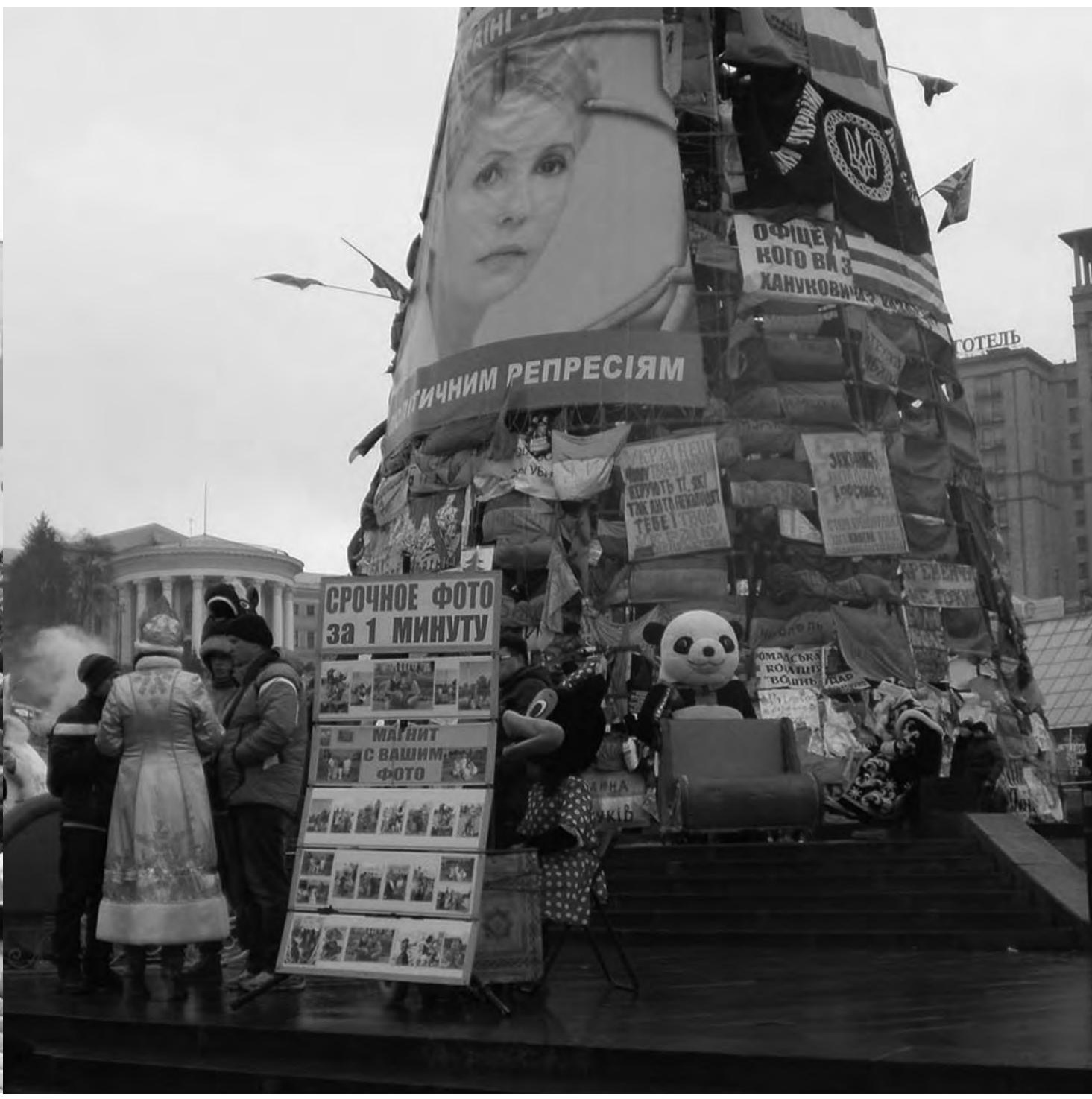




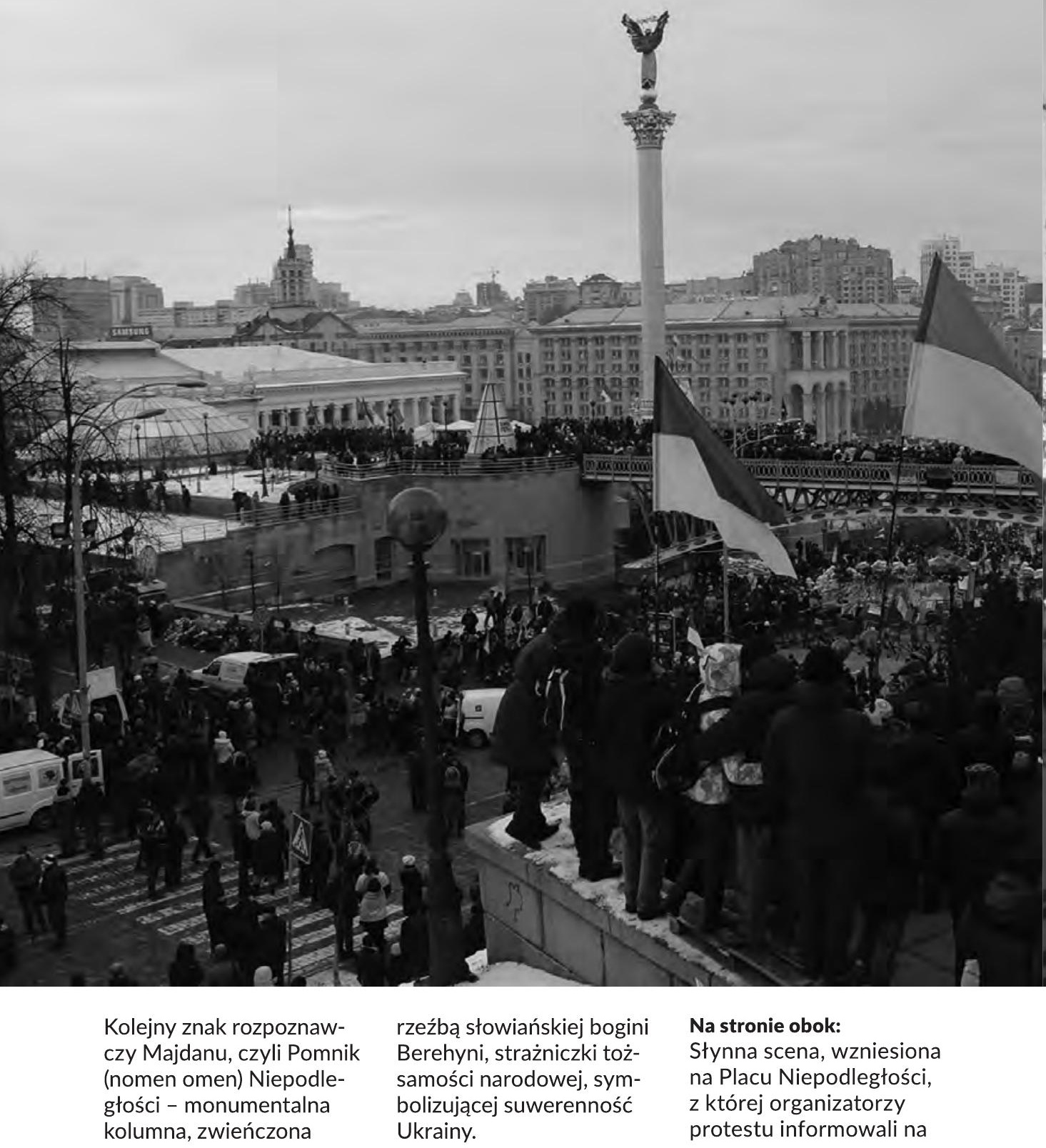




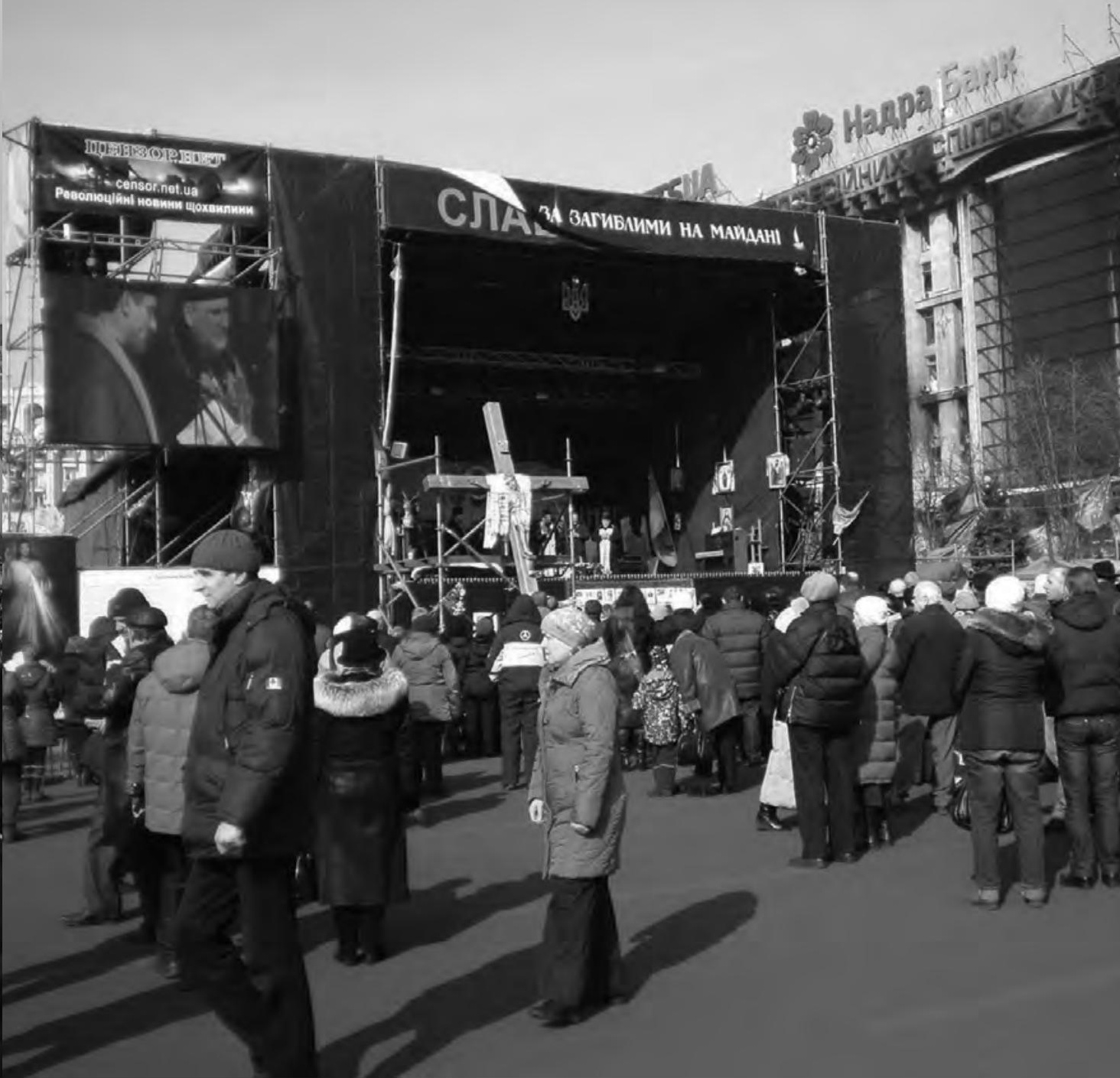

bieżąco jego uczestników o wydarzeniach w Kijowie i na Ukrainie oraz o reakcjach świata na sytuację nad Dnieprem, a także koordynowali przebieg działań na Placu Niepodległości. 

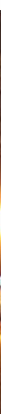

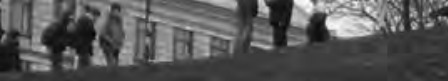




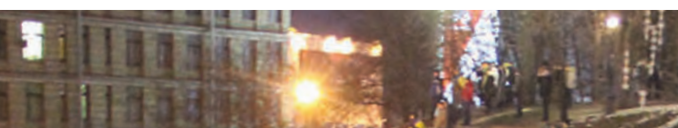

HI

He

(

$\mathrm{Es}$
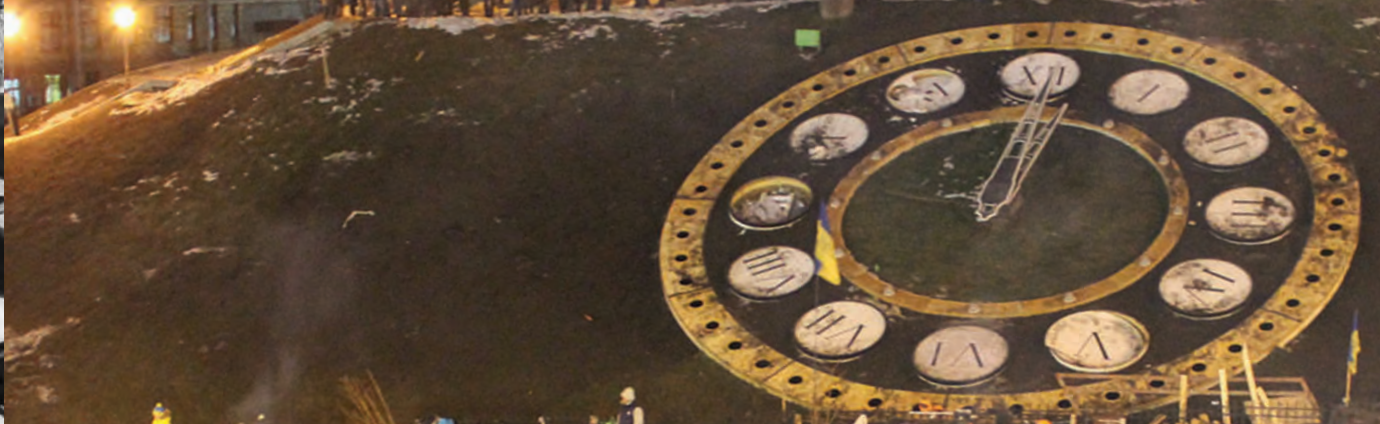

$40.04 x$.

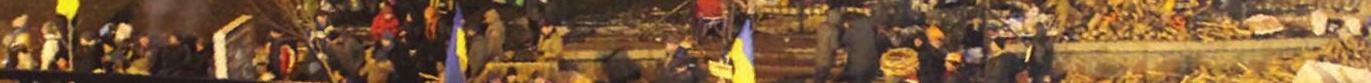

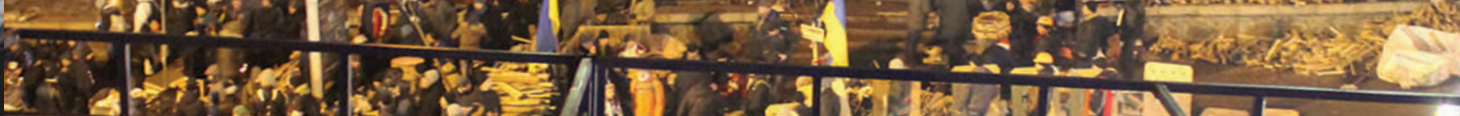

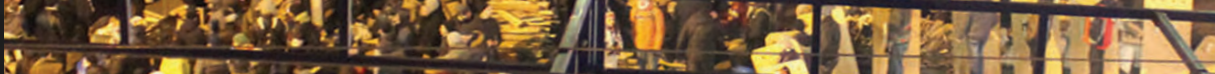

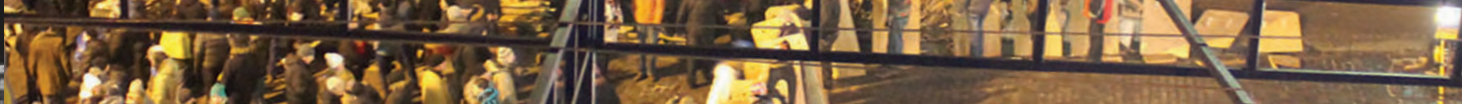

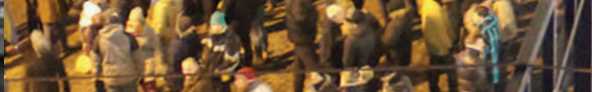

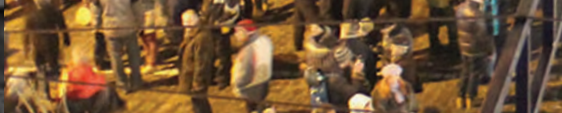
Nily $3=0$ a

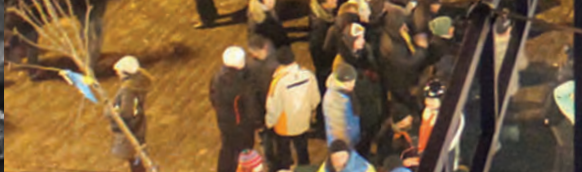

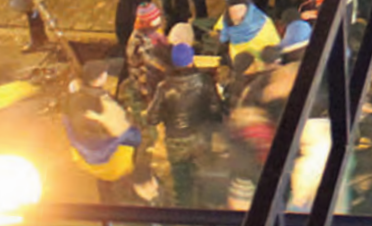
$\left.\frac{3}{2}\right)^{2}$ 


\section{GŁOSY NARODU}

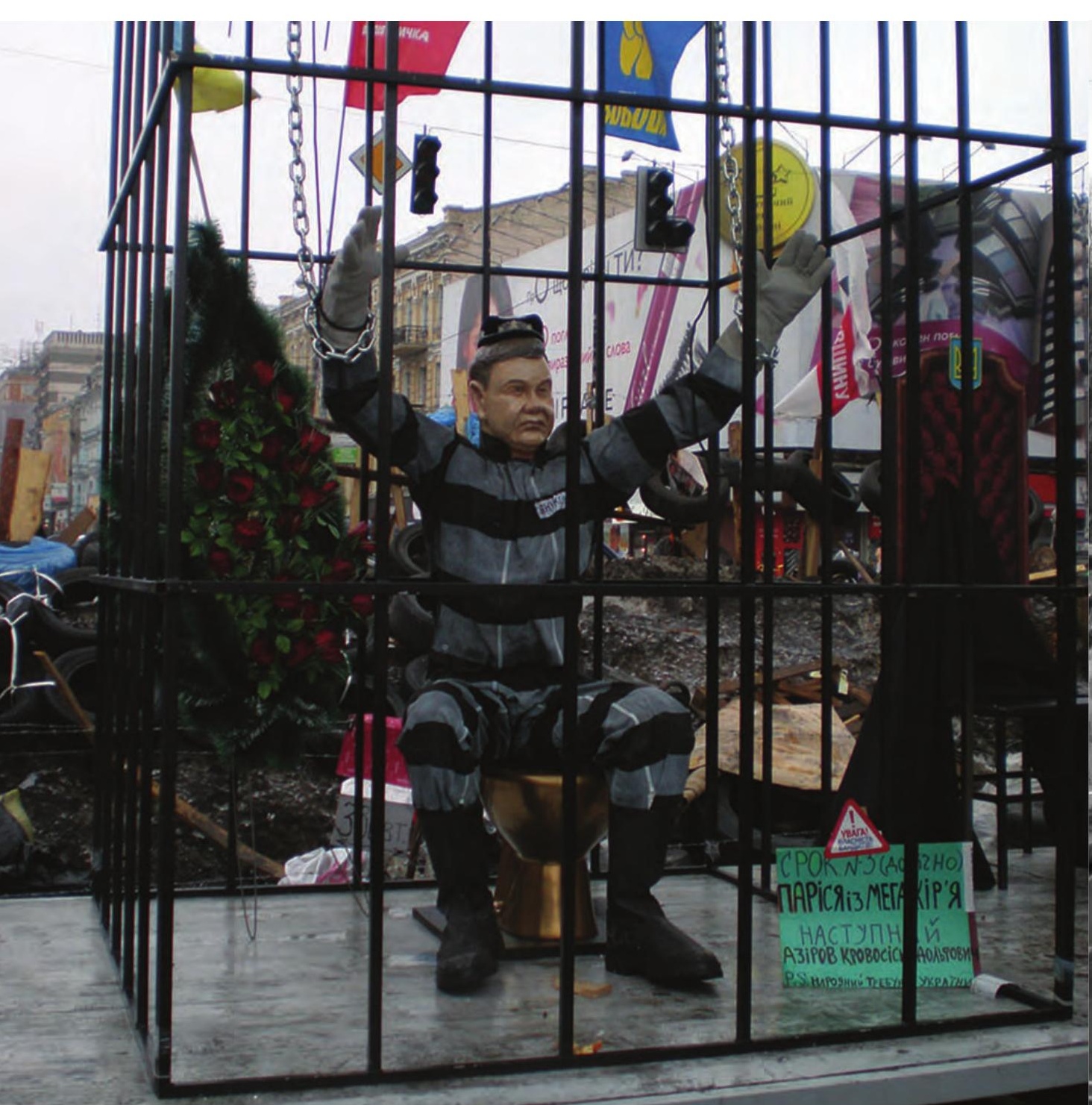

Tego życzyli protestujący na Placu Niepodlegości urzędującemu prezydentowi - kukła Janukowycza w klatce.
Na stronie obok:

Podobne życzenia roz-

szerzano na najbliższego

współpracownika Januko-

wycza - premiera Azarowa. 


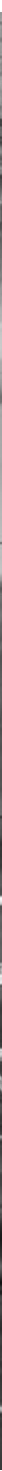




\section{Я્्К ПОВ' ЯЗЗАНІ КОМПАНII, ЩО ОТРИМАЛИ КОШТИ НА УТЕПЛЕННЯ}
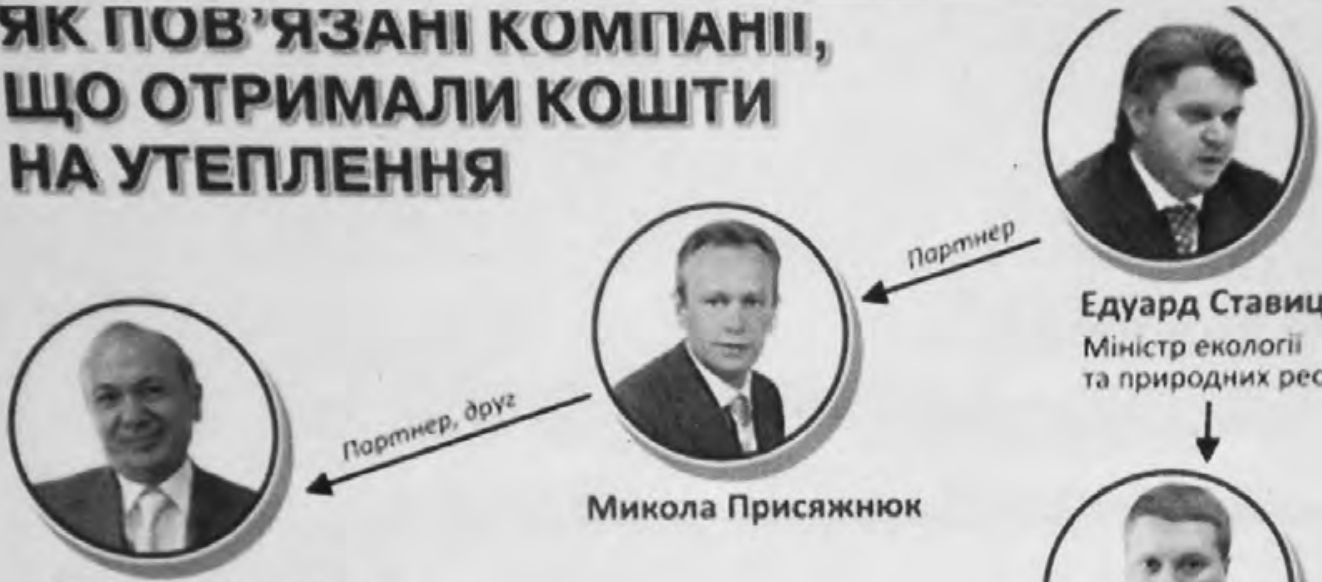

Едуард Ставицький Міністр екологіi

та природних ресурсів

Микола Присяжнюк

Юрій Іванющенко
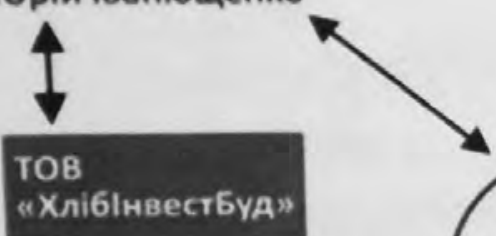

$\mathrm{Kn}$
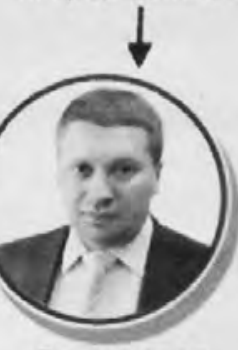

Владислав

Якубовський

Державне агентство екологічних інвестицій

$\downarrow$

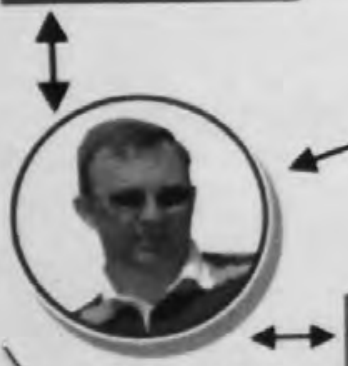

Андрій Остапко

TOB

«Гормашсна 6 ,

Михайло єжель

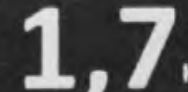

мільярда гривень

на утеплення

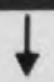

TOB

TOB

"Антіс трейд"

"Стройінвест 2007"

Rozpracowana i upubliczniana przez "majdanowów" sieć aferalnych powiązań Aleksandra Janukowycza.
Na stronie obok:

Ściany to dobre miejsce do umieszczania patriotycznych plakatów i malowidet. 


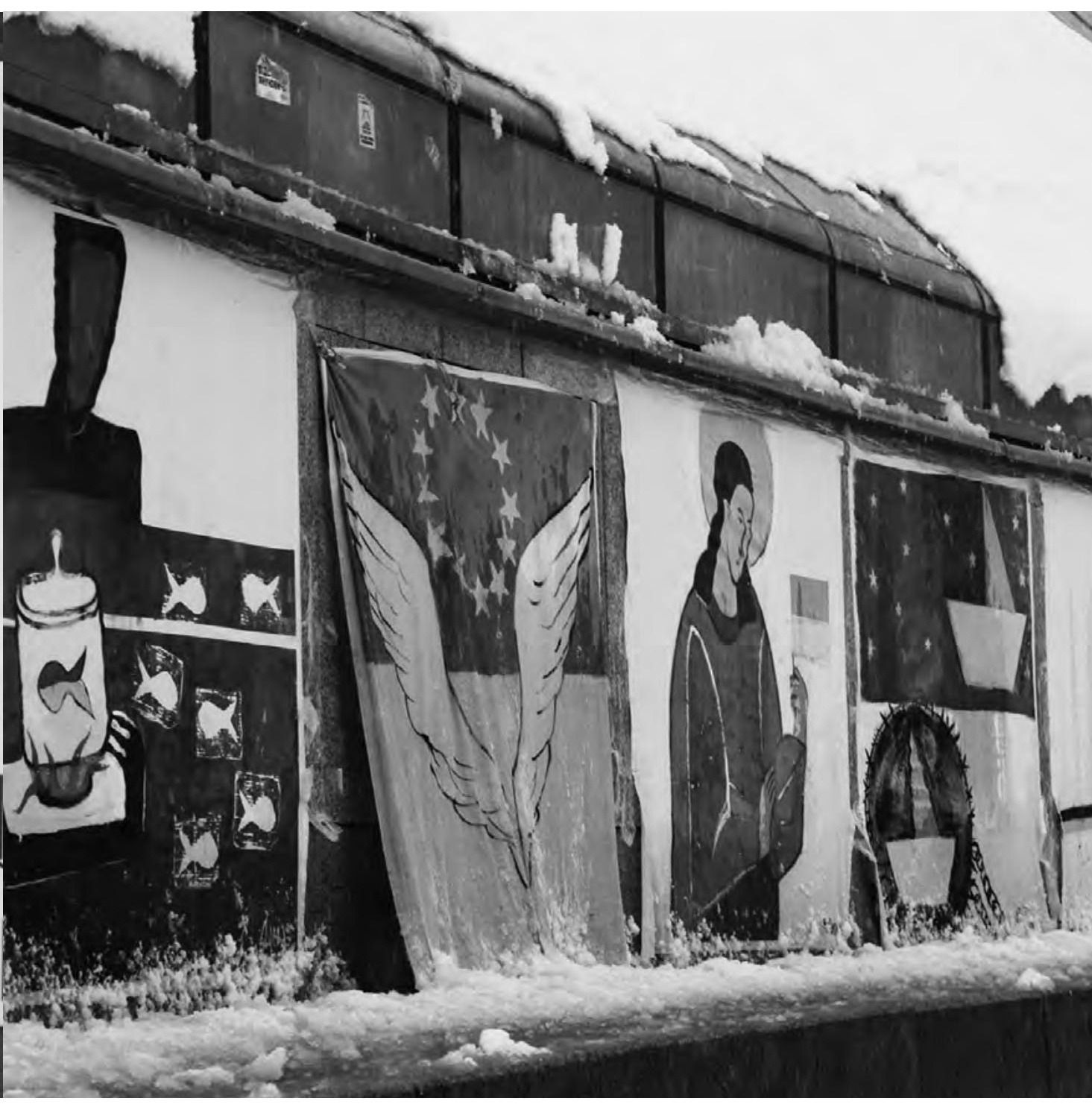




\section{ОБИРАЙ! =}

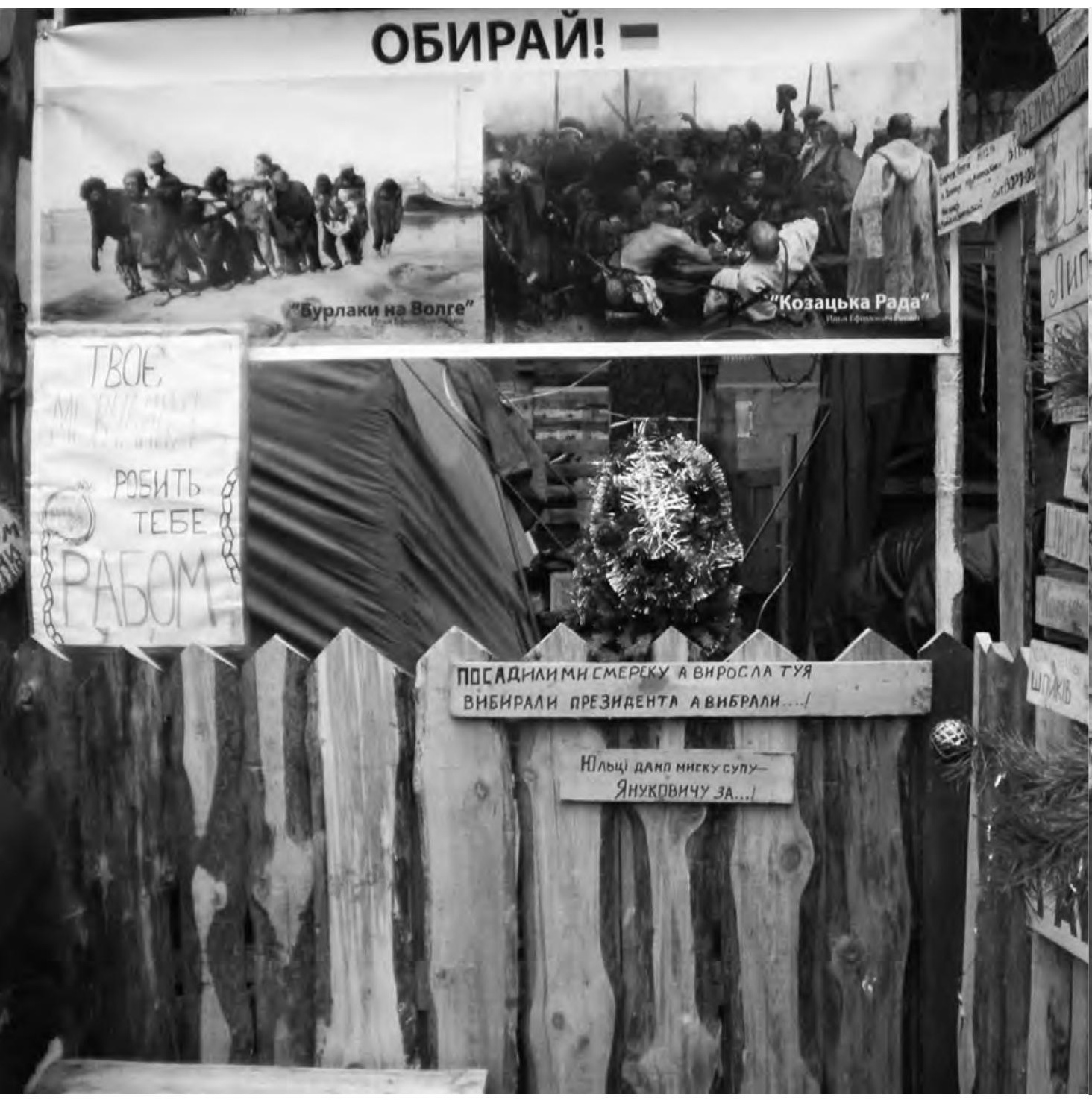

Metody mobilizacji. Retoryczne pytanie o przyszłość narodu i państwa.
Na stronie obok:

Pamięć. Zaimprowizowana „Aleja Sławy" z nazwiskami bojowników, którzy zginęli w obronie Euromajdanu oraz uczestników walk z siłami rządowymi. 


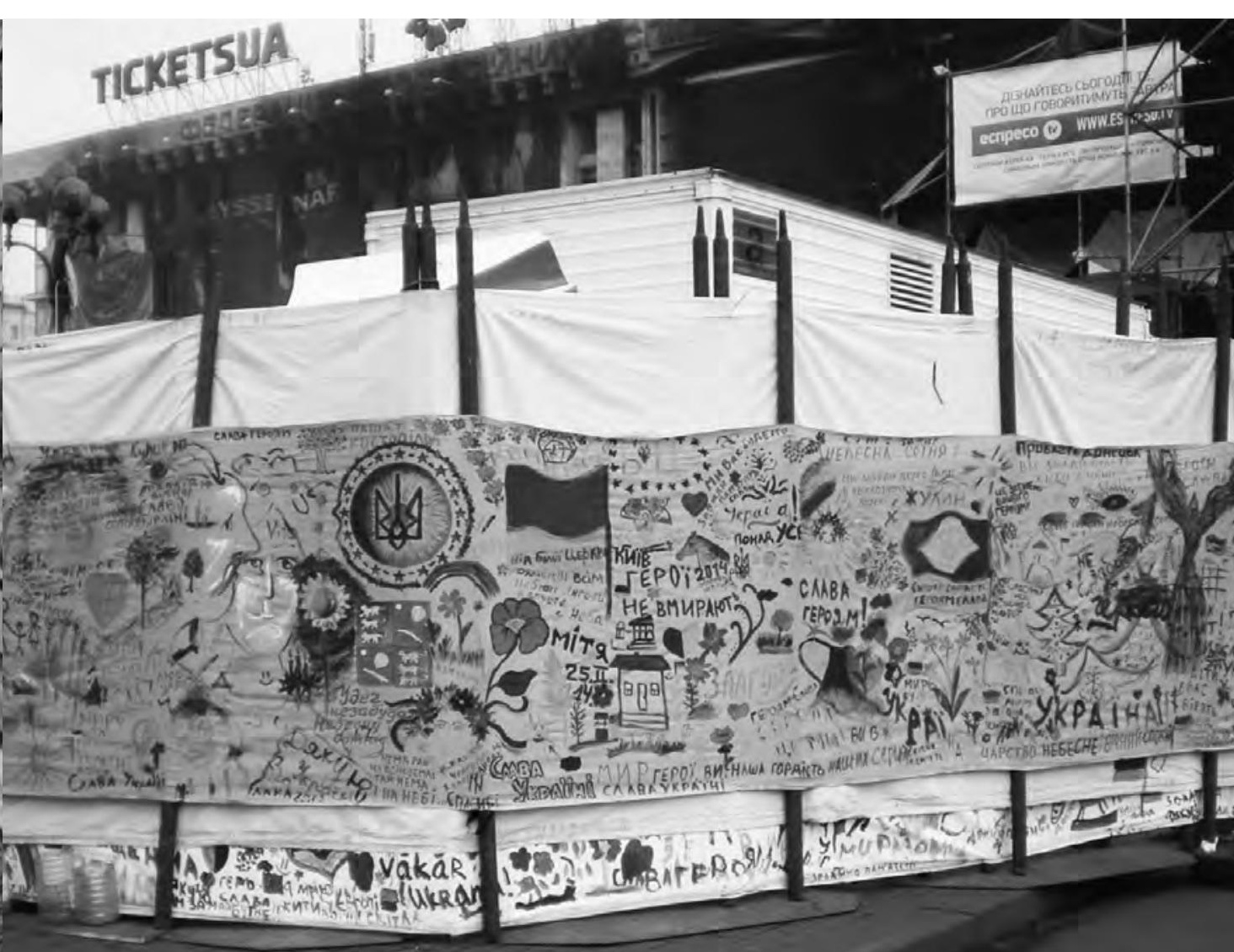




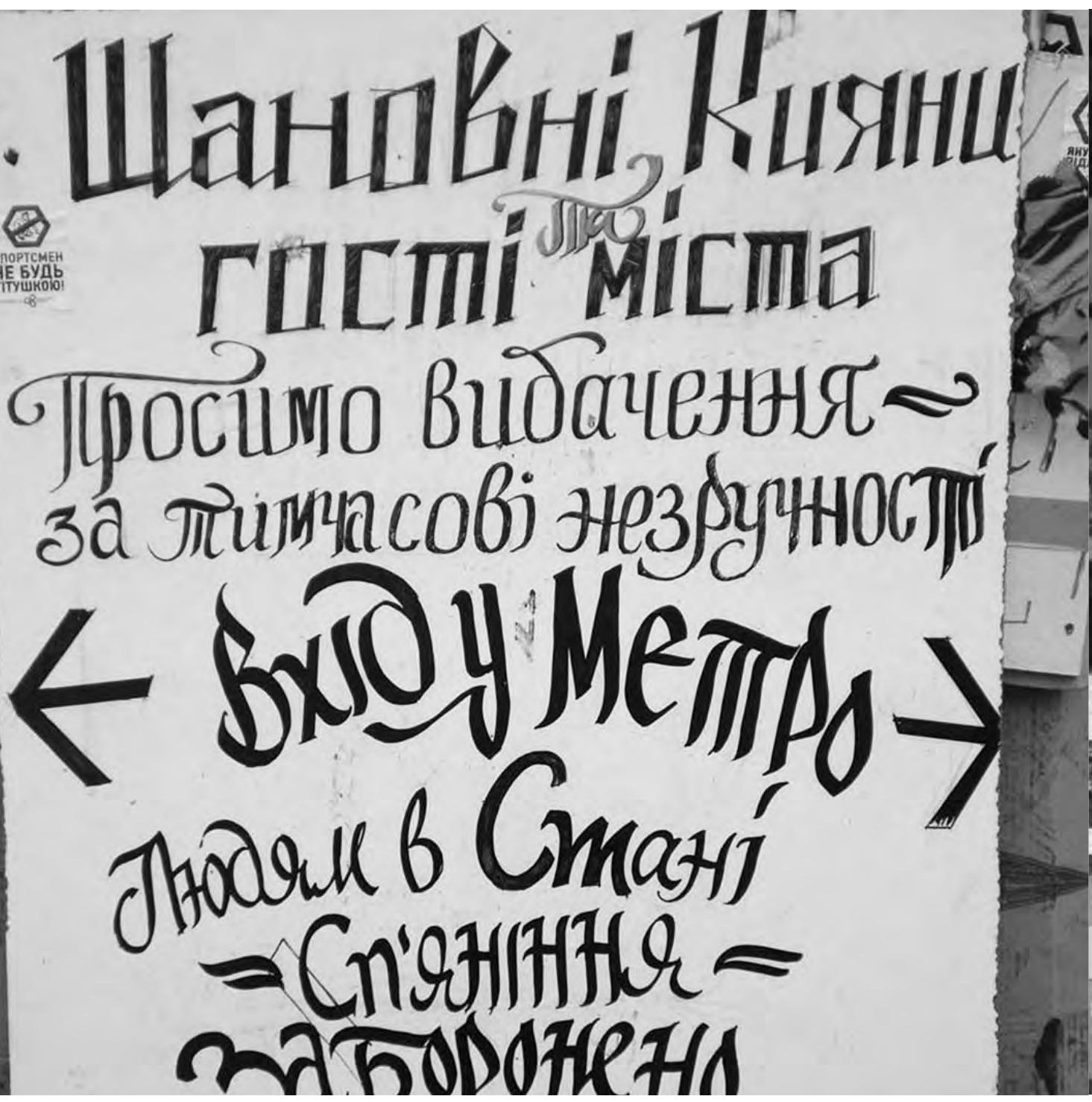

Tablica z podstawowymi informacjami dla protestujących i odwiedzających Plac Niepodległości.
Na stronie obok:

Prowizoryczna tabli-

ca z komunikatami dla uczestników protestu przy budynku kijowskiej Rady Miejskiej. 


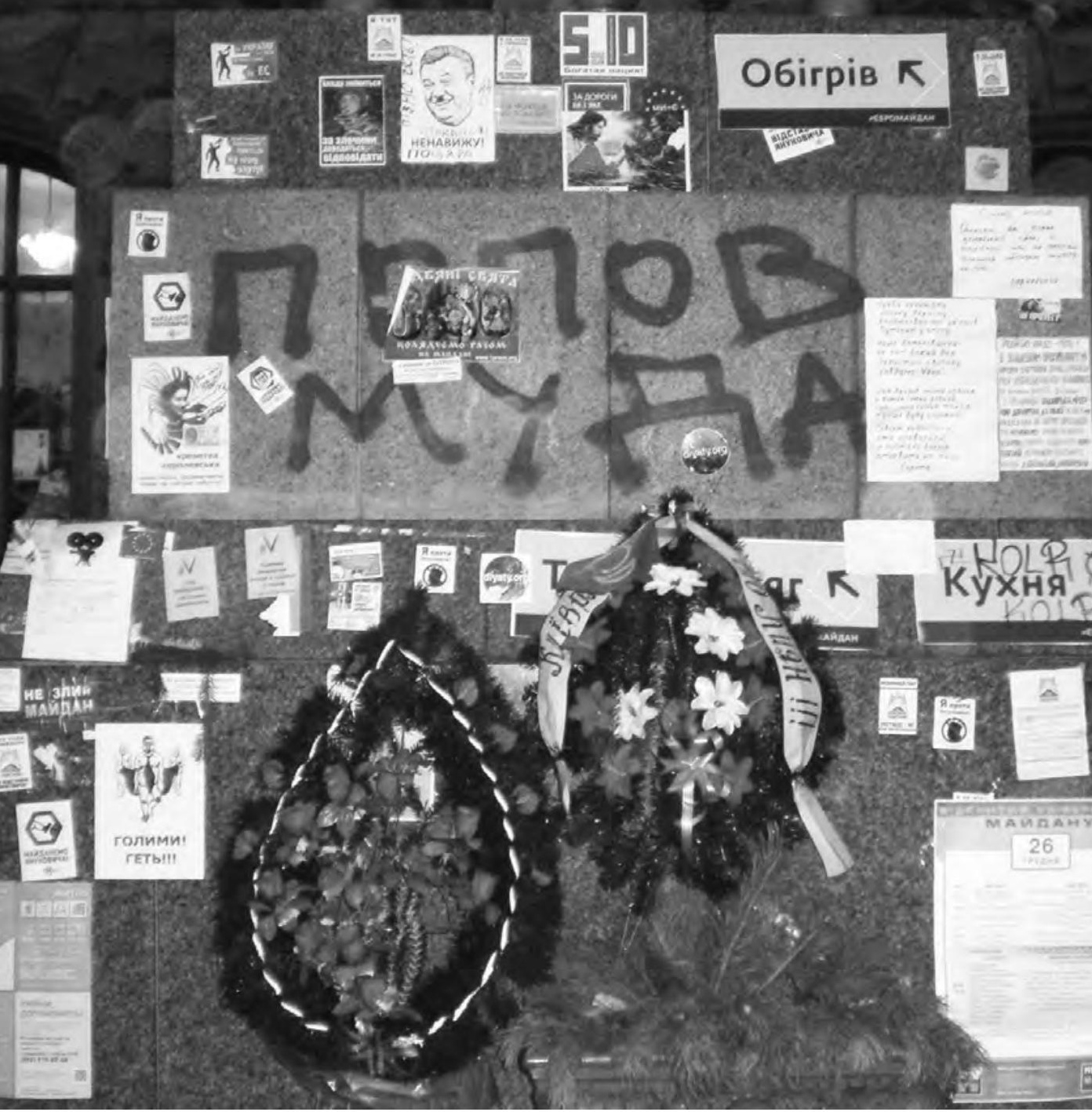




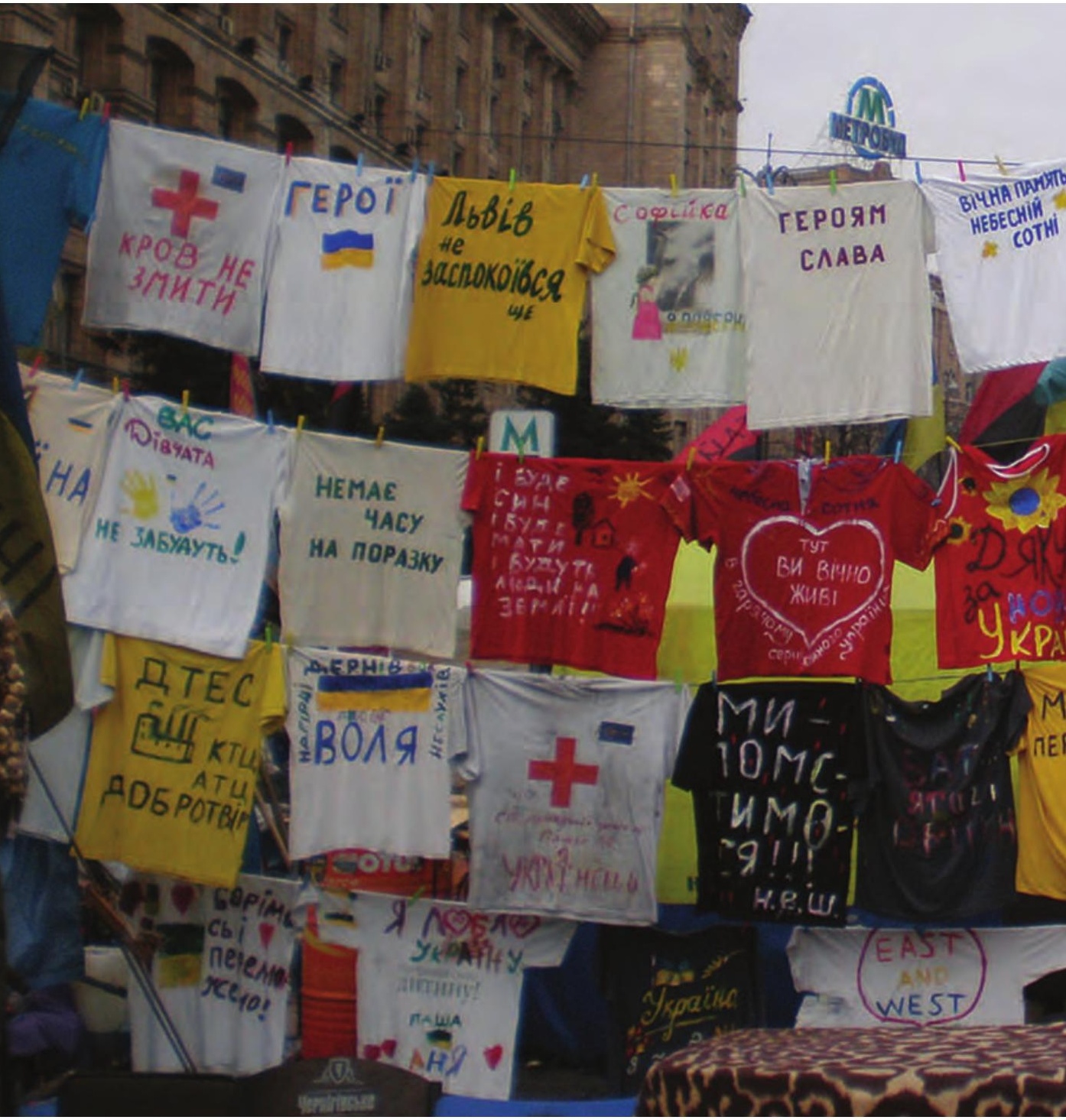

Niecodzienna wystawa koszulek uczestników Euromajdanu. 


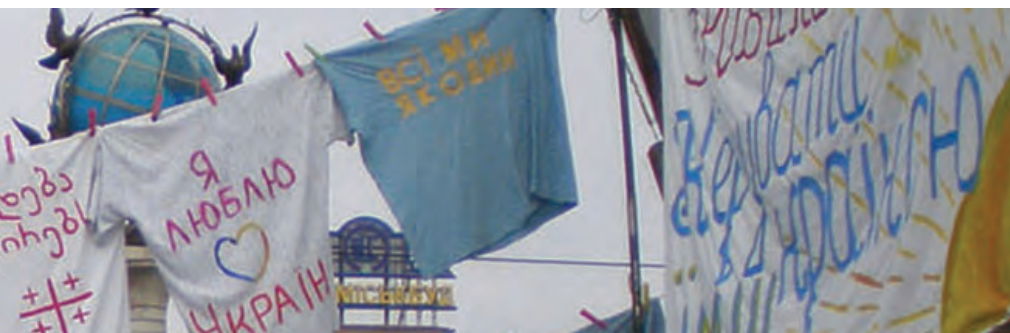

TEPOIB $\quad \frac{+1_{+}^{+}}{+1}$ yKPA

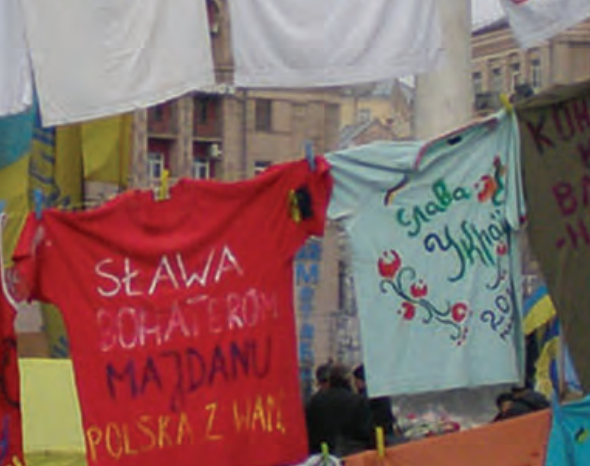

(ii)

1) (4t. StAWA

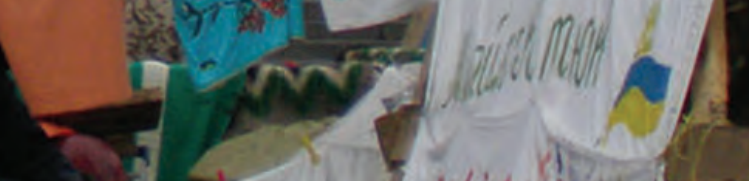

(annew

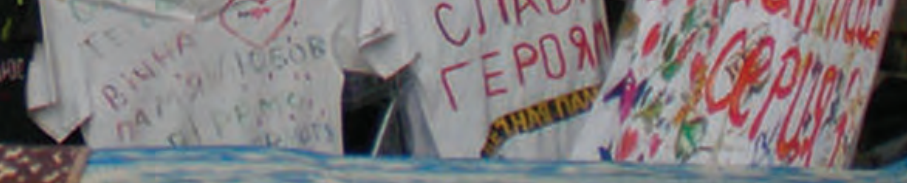

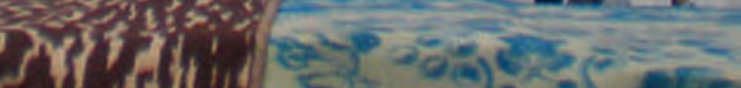




\section{BARYKADY - GRANICE WOLNOŚCI}

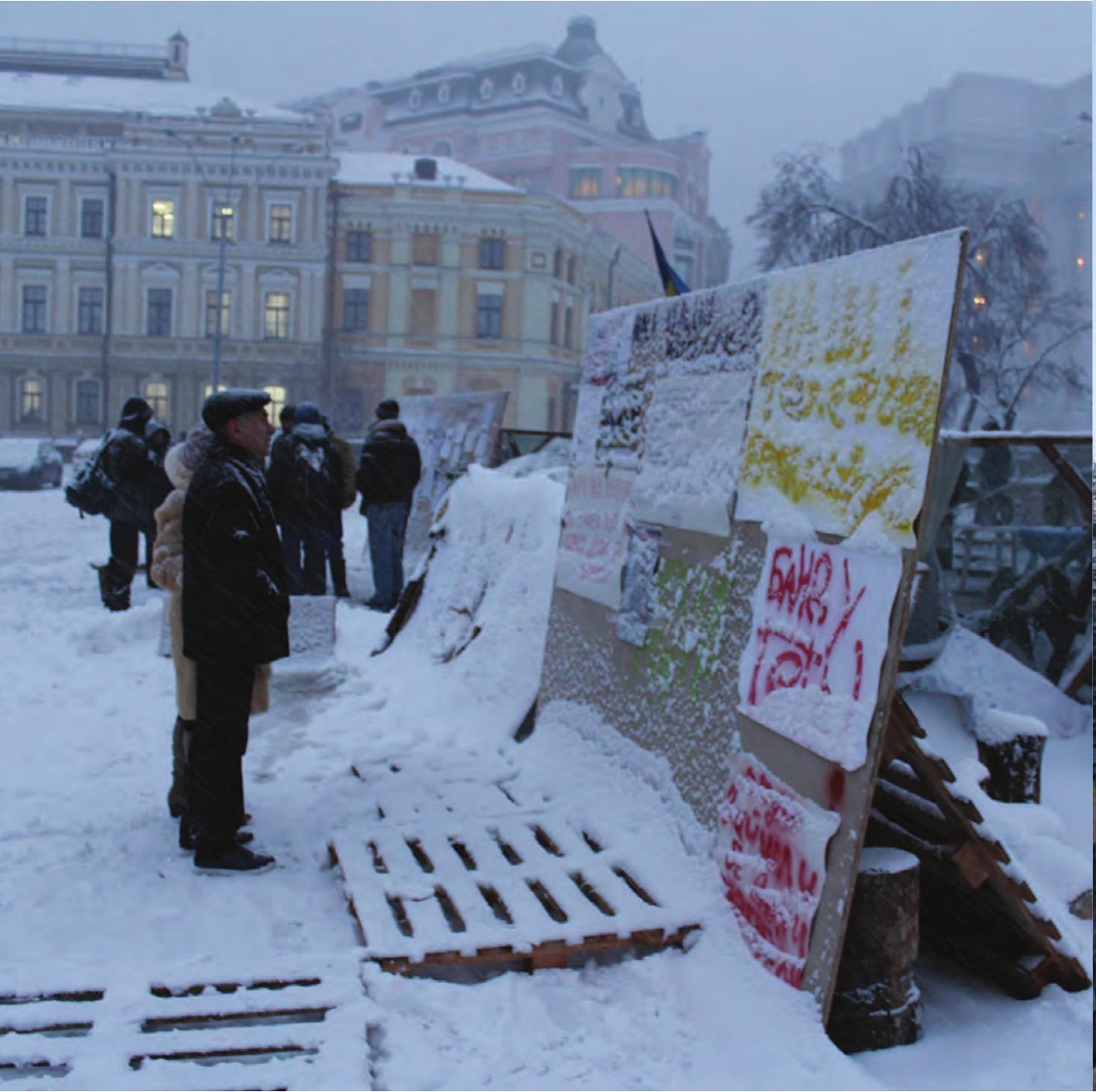

Pierwsze prowizoryczne barykady. Póki co bardziej użyteczne jako miejsce do wywieszania ogłoszeń i politycznych haset.
Na stronie obok:

Solidna barykada "drugiej generacji" z worków z piaskiem i z ziemią pod mostem na Instytuckiej. $\mathrm{Na}$ barykadzie flagi Ukrainy, Unii Europejskiej i wskazujące na solidarność ukraińsko-białoruską. 


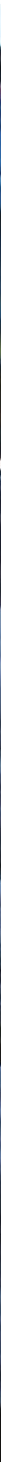




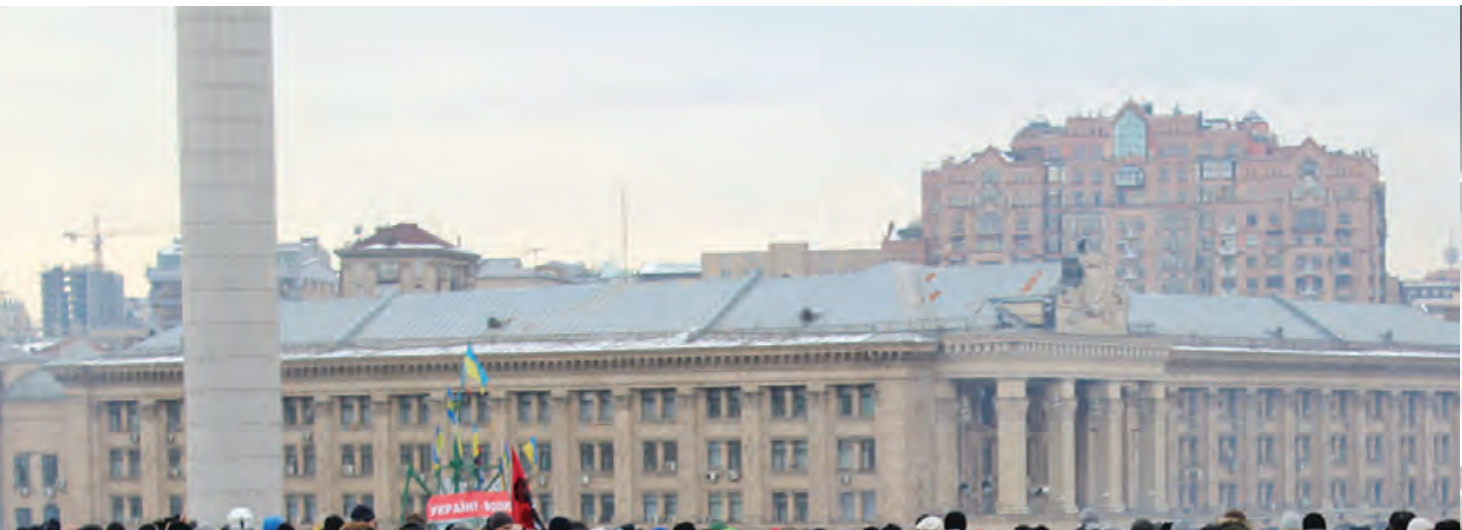

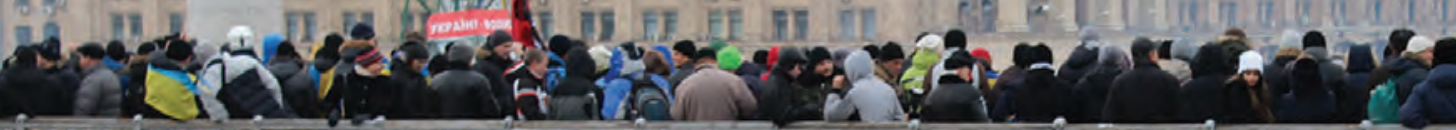

D.w. $000000000000000,1 \times 20000000$

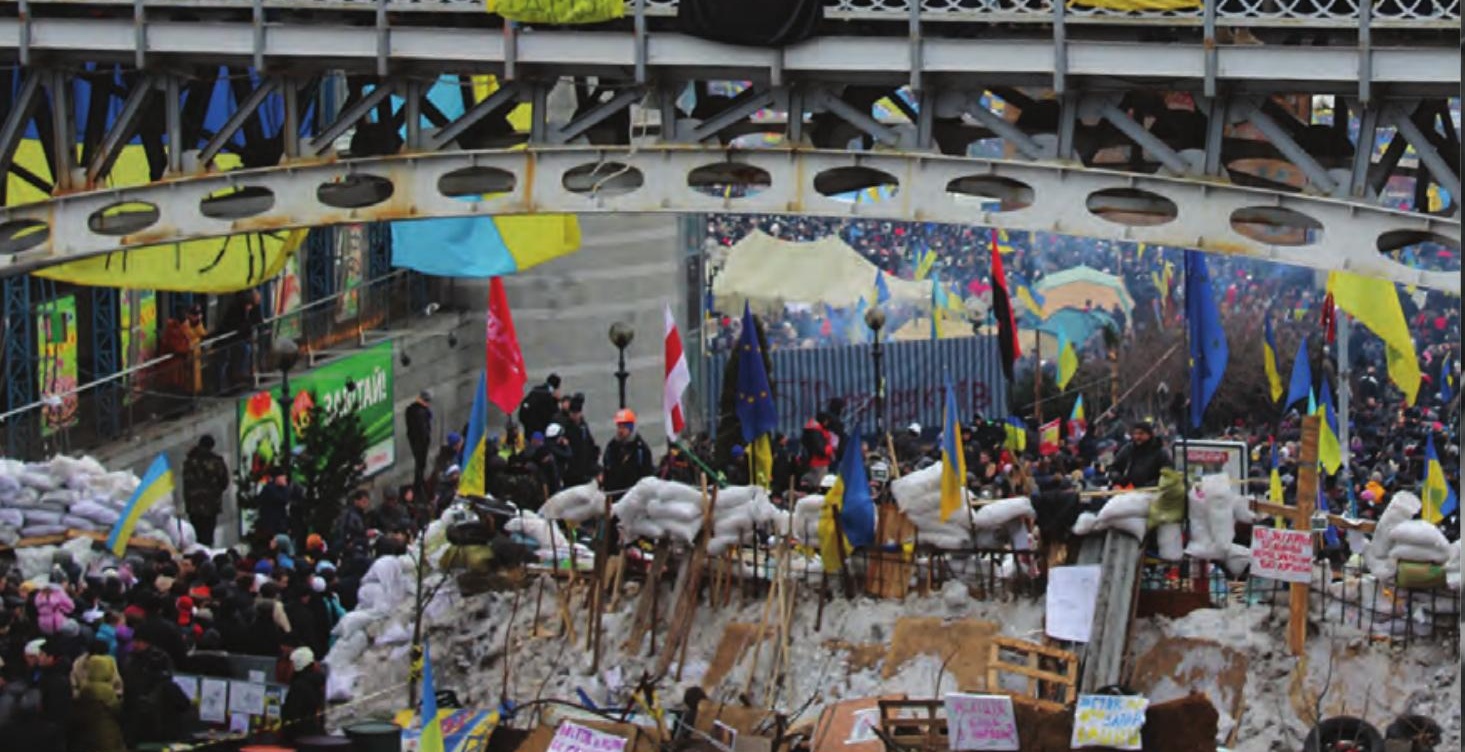

Budowa zakończona.

Oflagowana barykada pod mostem na Instytuckiej.

\section{Na stronie obok:}

Prowizoryczna barykada

pod pokrytym śniegiem

Kwiatowym Zegarem przy ulicy Instytuckiej. 


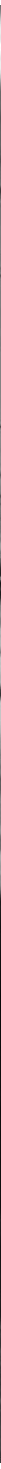




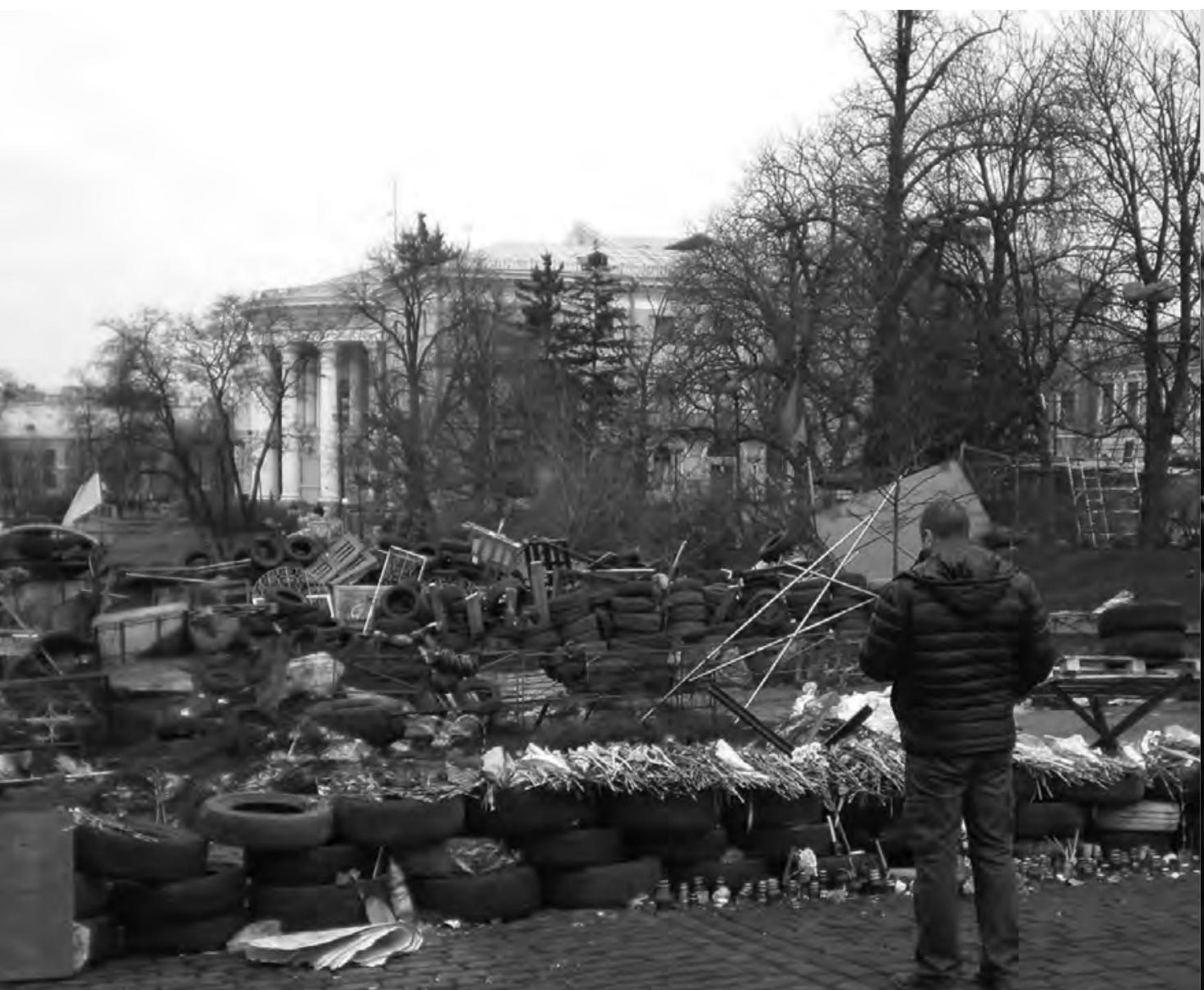

Barykada na ul. Instytuckiej po walkach. Konstrukcja została obłożona oponami, które podpalone w momencie szturmu oddziałów milicyjnych, miały utrudnić im sforsowanie przeszkody.
Na stronie obok:

Obłożona oponami i workami z piaskiem, zwieńczona metalowym 

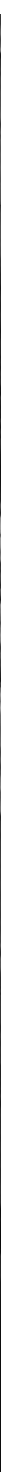

ogrodzeniem i narodowy-

mi barwami barykada na

Chreszczatyku przy placu

Niepodległości. 


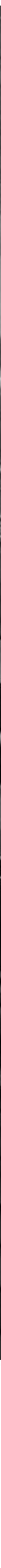




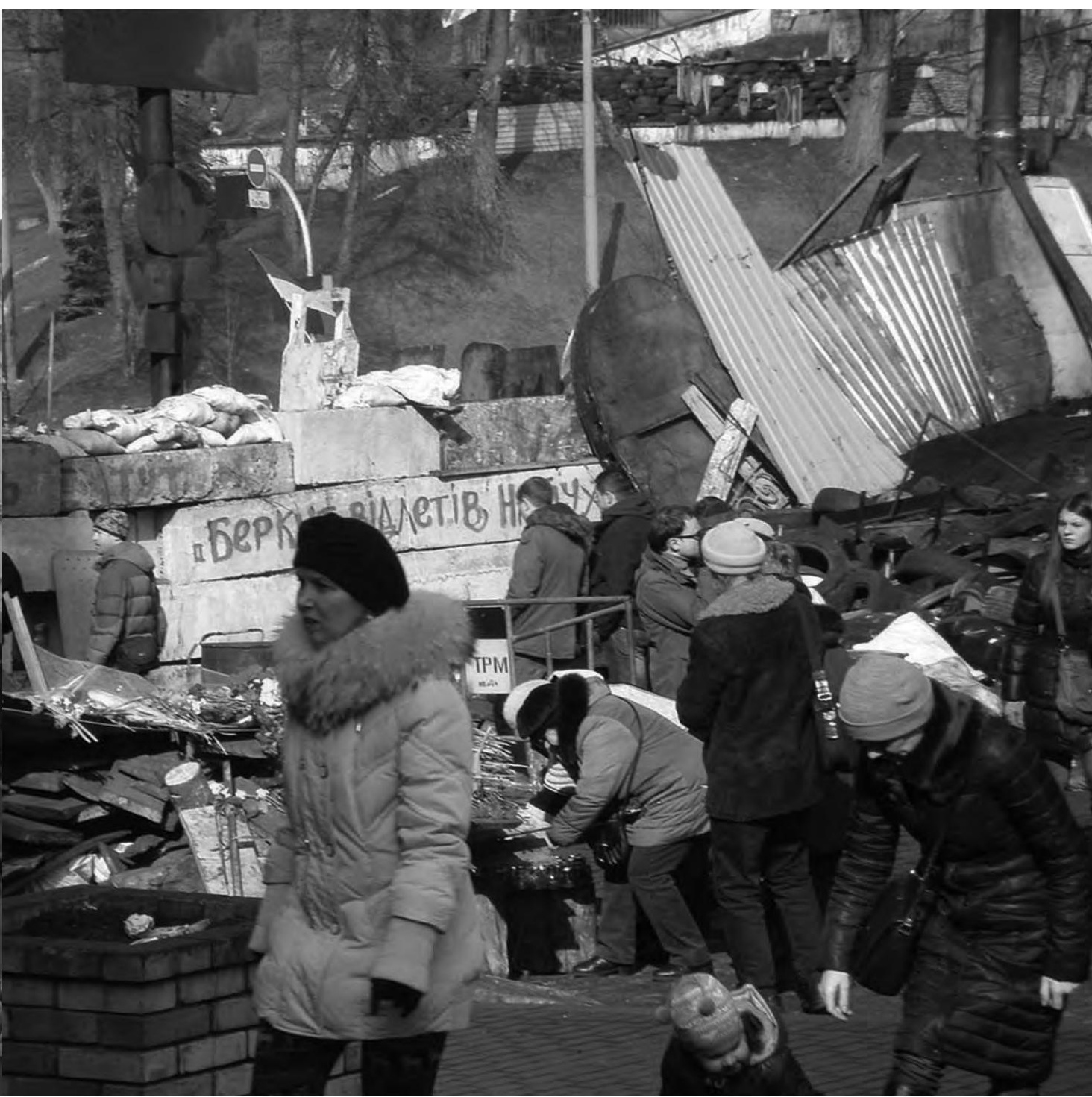

kamienne, betonowe

i cementowe bloki i cegły. 


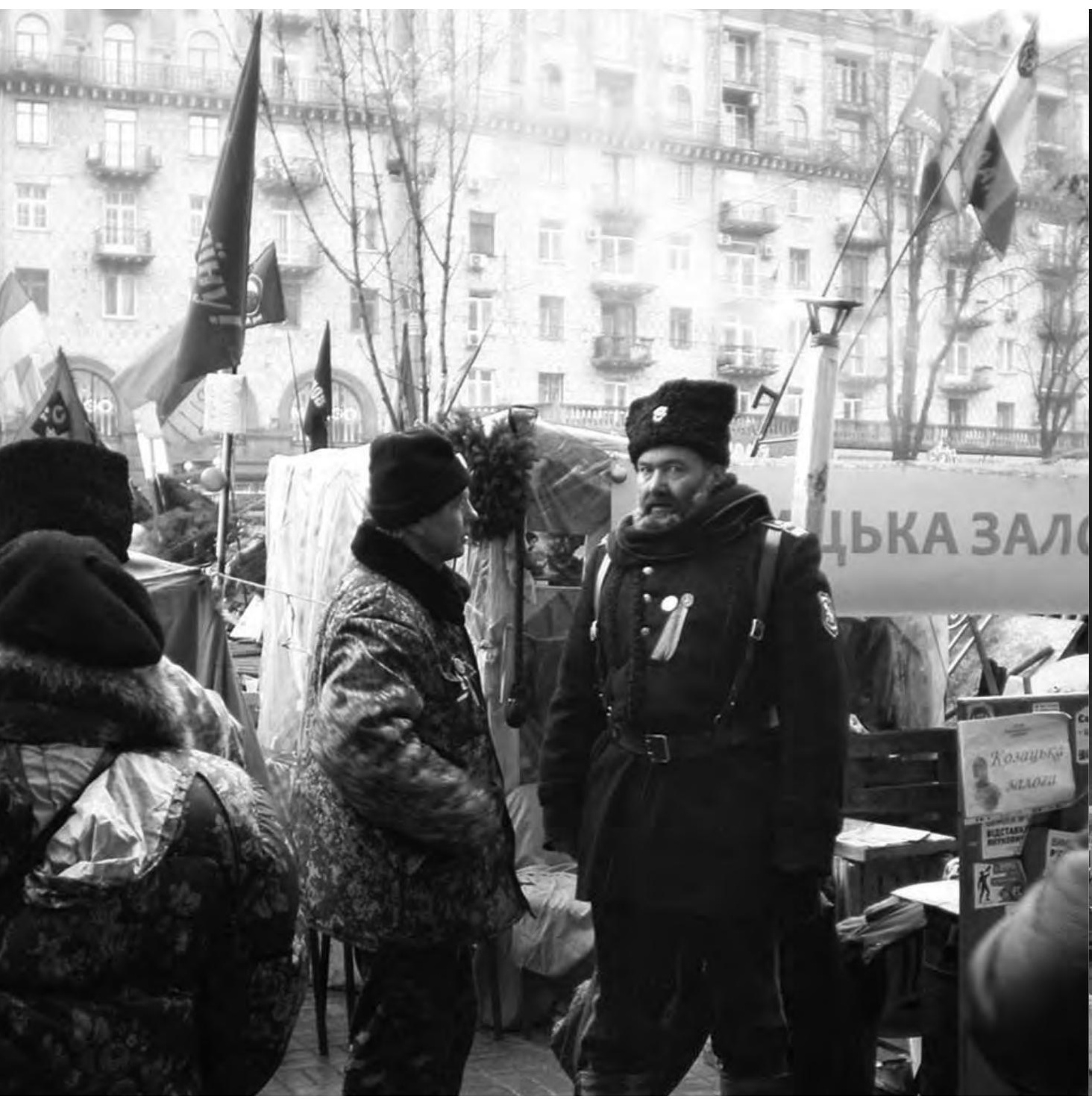

Posterunki kontrolne

- druga po barykadach

linia ochronna Majdanu.

Strażnicy „filtrują" wchodzących na Plac
Niepodległości, usiłując uniemożliwić dostanie się nań prowokatorów i agentów bezpieki Janukowycza.
Na stronie obok:

Fragmenty innych... 


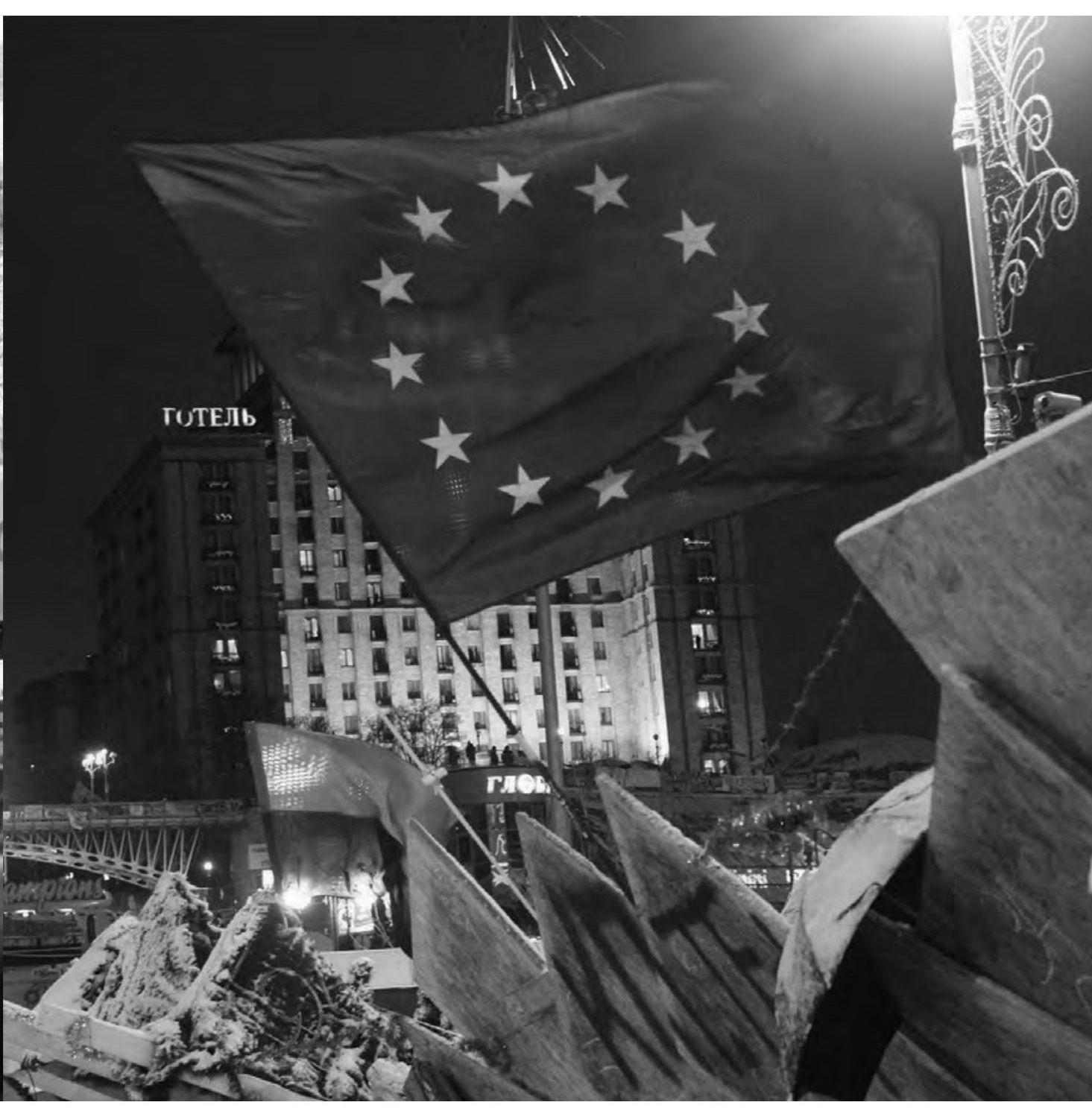




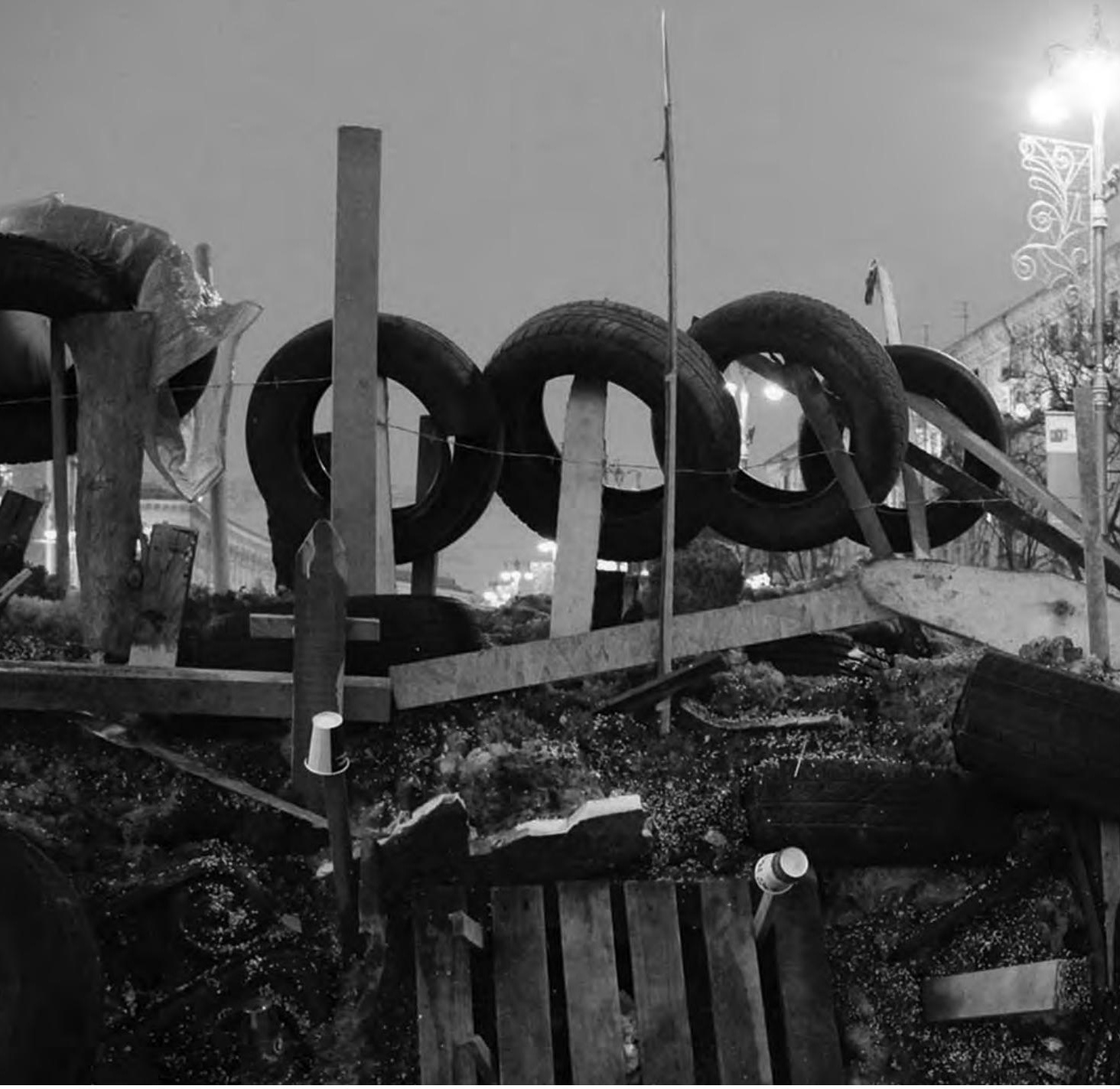

...barykad Majdanu. 


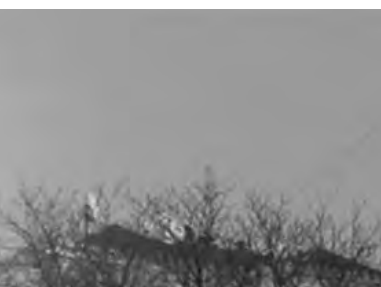

3.5.

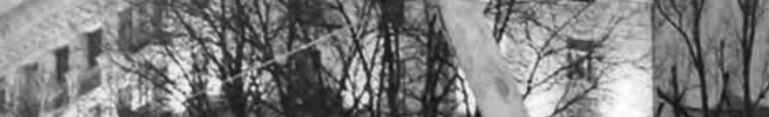

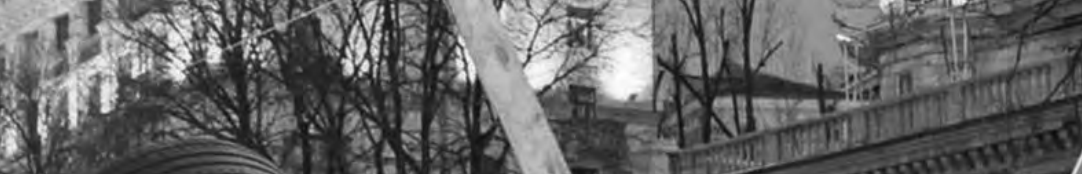

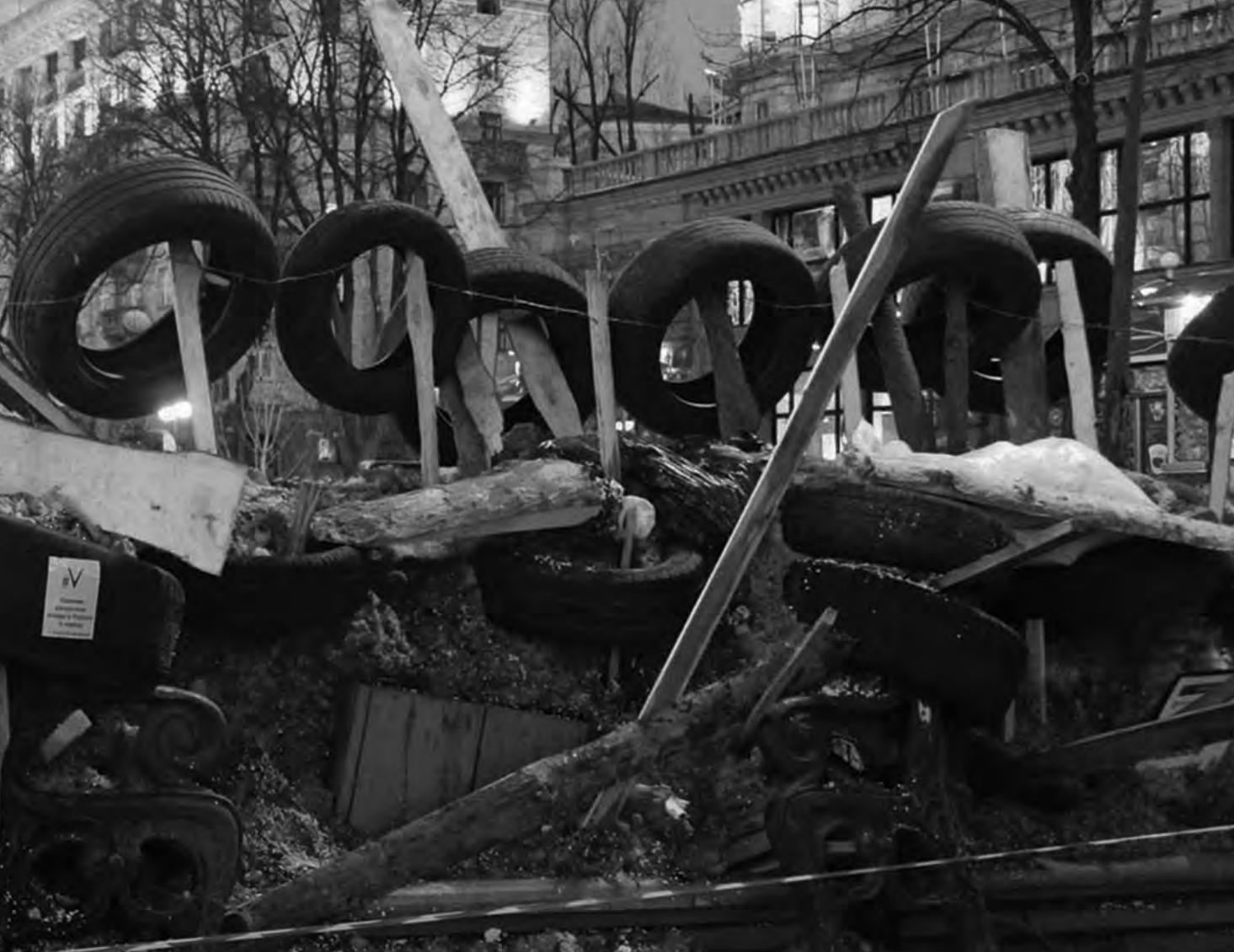


WRÓG

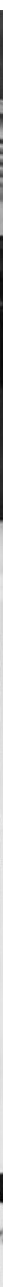

Po uzyskaniu niepodległości przez Ukrainę nad Dnieprem powołana została do życia nowa formacja milicyjna. Jej nazwa Berkut - po ukraińsku orzeł - stała się po wydarzeniach na Majda- nie synonimem krwawej rozprawy władzy ze społeczeństwem. 

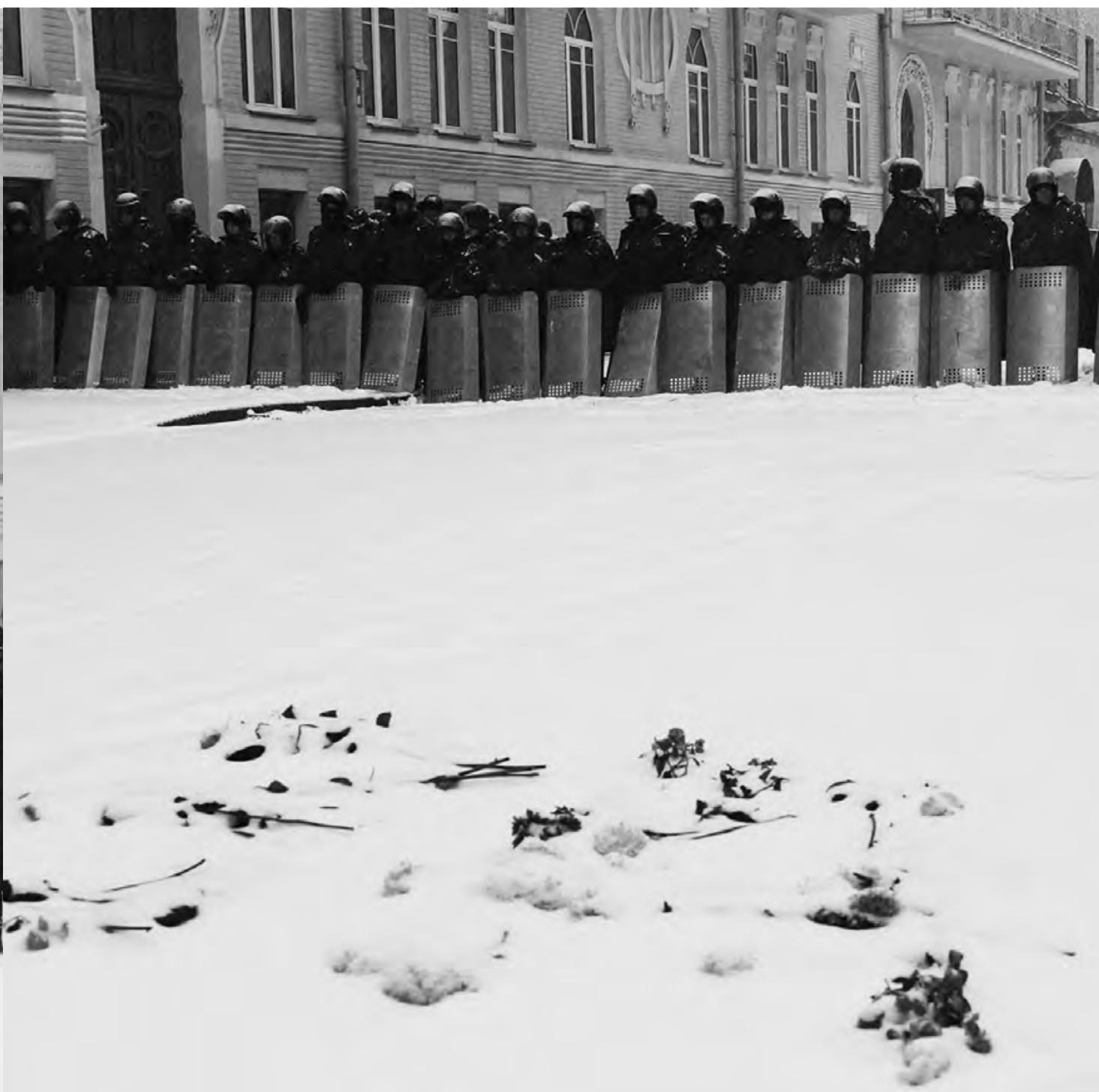

Na zdjęciach - berkutowcy... 


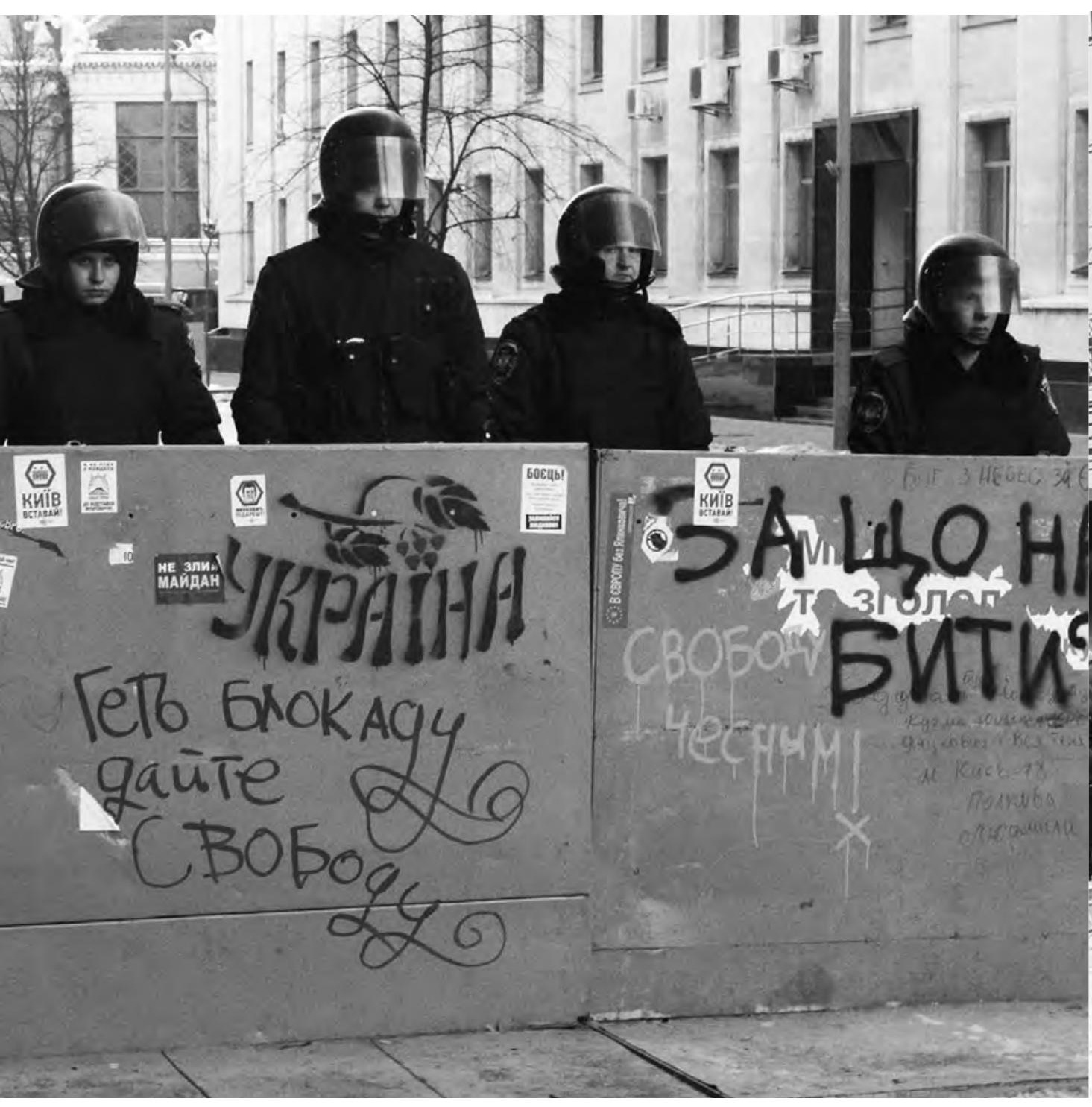

...przed siedzibami centralnych urzędów państwowych w Kijowie.
Na stronie obok:

Pozycje Berkutu na skrzyżowaniu ulic Chreszczatyk i Chmielnickiego przy
Placu Niepodległości.

Panowanie nad nim umożliwiało w znacznym stopniu kontrolowanie napływu ludzi na Plac. 


\section{पEKAEMO HA BAC У ЦЕНТРАХ ОБСЛУГОВУВАННЯ ПЛАТНИКІВ ПОДАТКІВ}

\section{回的回}

425 3А TEЛЕФОНОМ 0-800-501-007 回㨁 www minrd.gov.ua
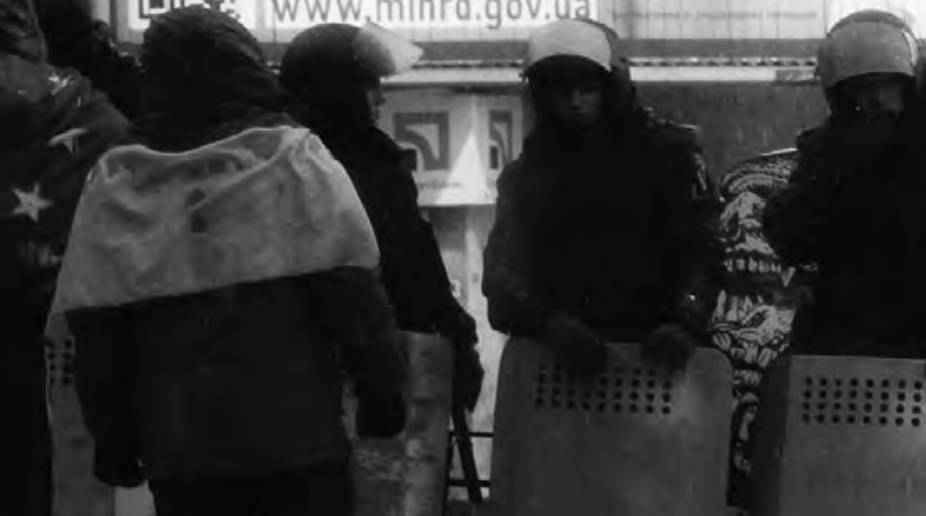

4

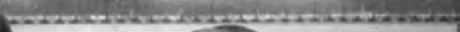

Fragment tzw. czarnego pierścienia. Tym mianem kijowianie i uczestnicy protestu na Majdanie określali stanowiska ber- kutowców bezpośrednio wokół Majdanu.
Na stronie obok:

Nieliczna demonstracja zwolenników reżimu w kijowskim Parku Marińskim (Maryjskim). 


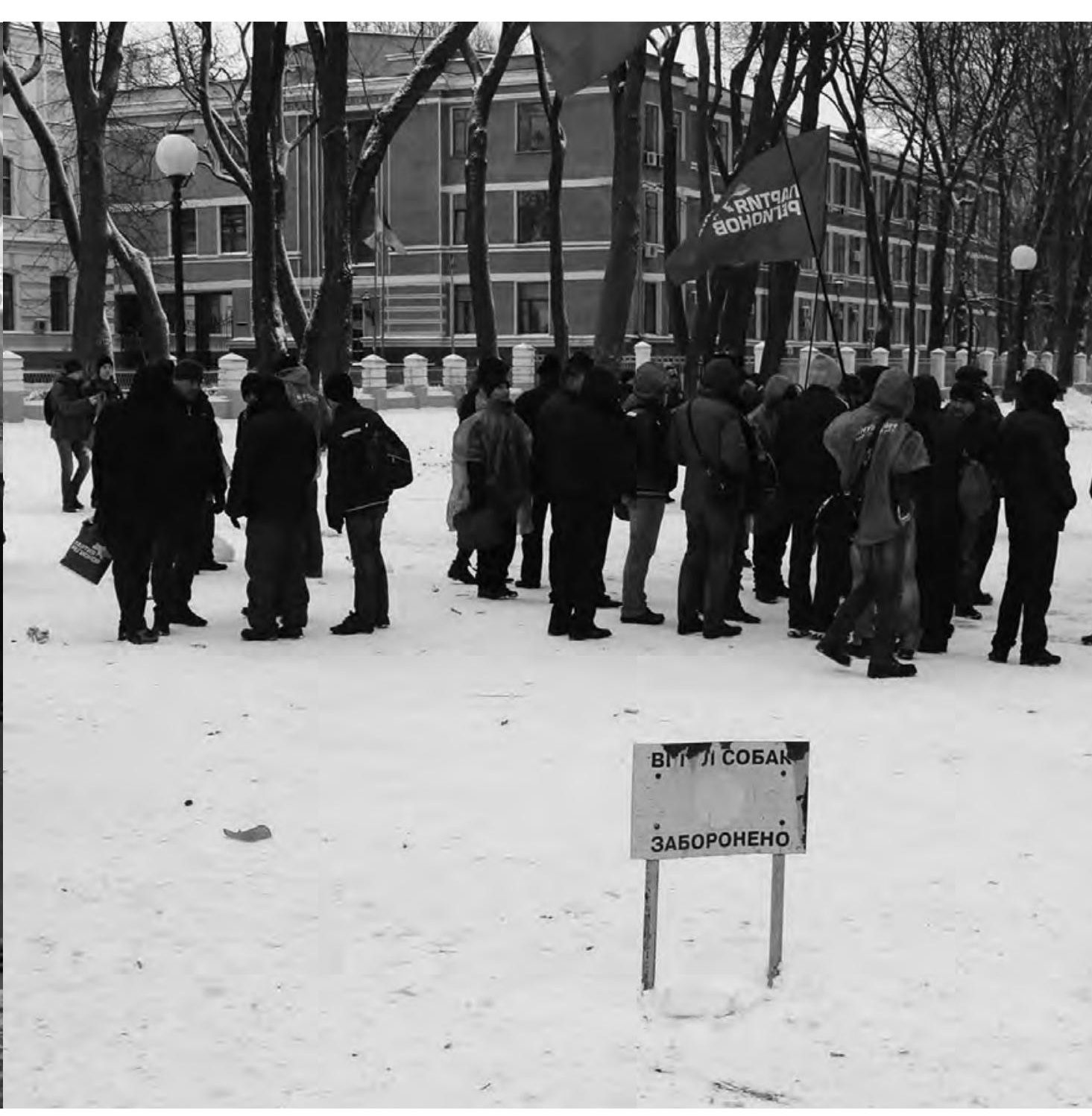




\section{BITWA}

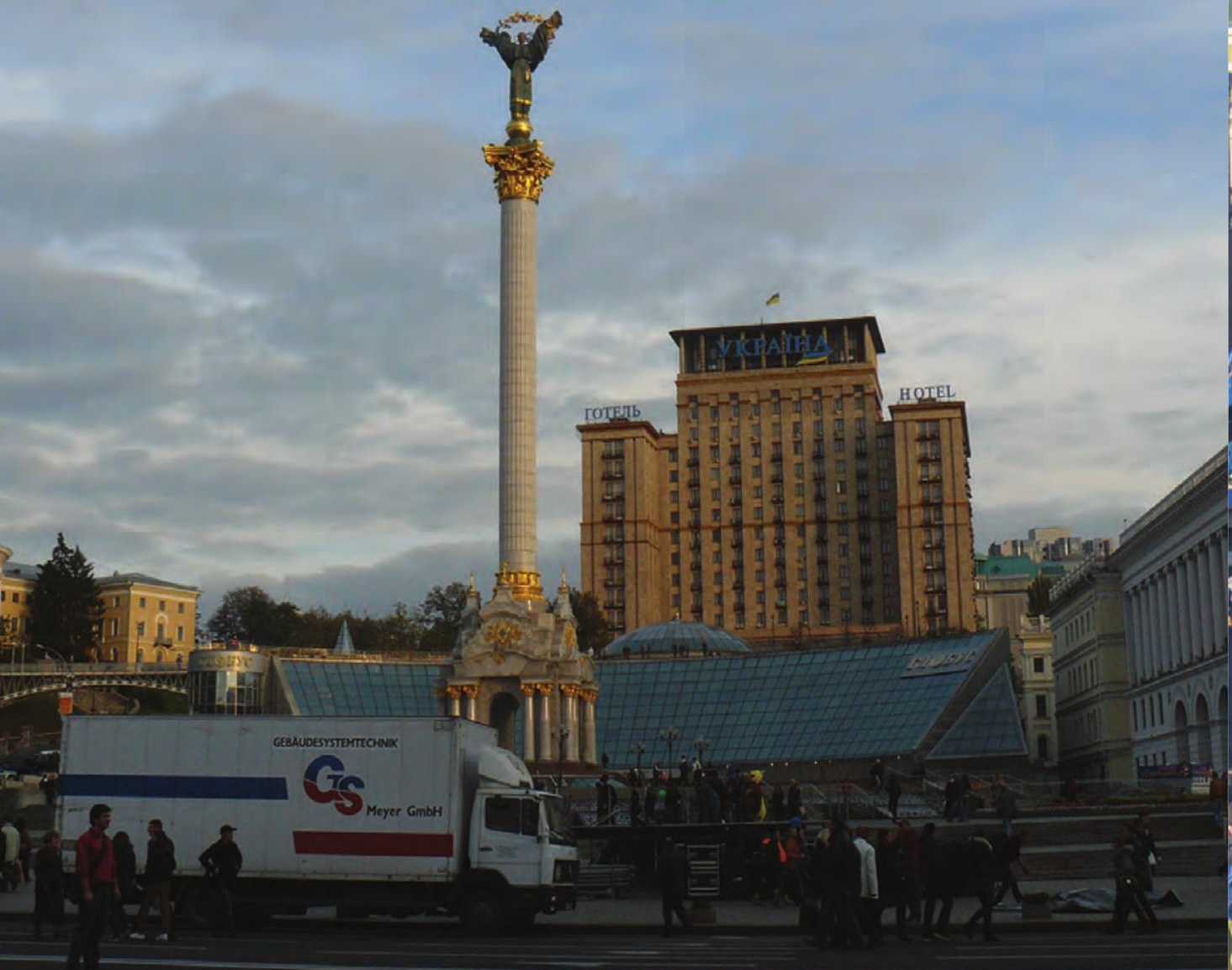

Spokój przed burzą... Plac Niepodległości w przededniu protestów - koniec października 2013 roku.
Na stronie obok: Plac Niepodległości w czasie kijowskiego tzw. Marszu Milionów, zorganizowanego przez przeciwników reżimu Janukowycza 8 grudnia 2013 roku. 


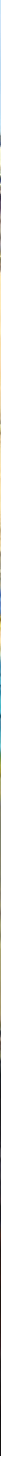




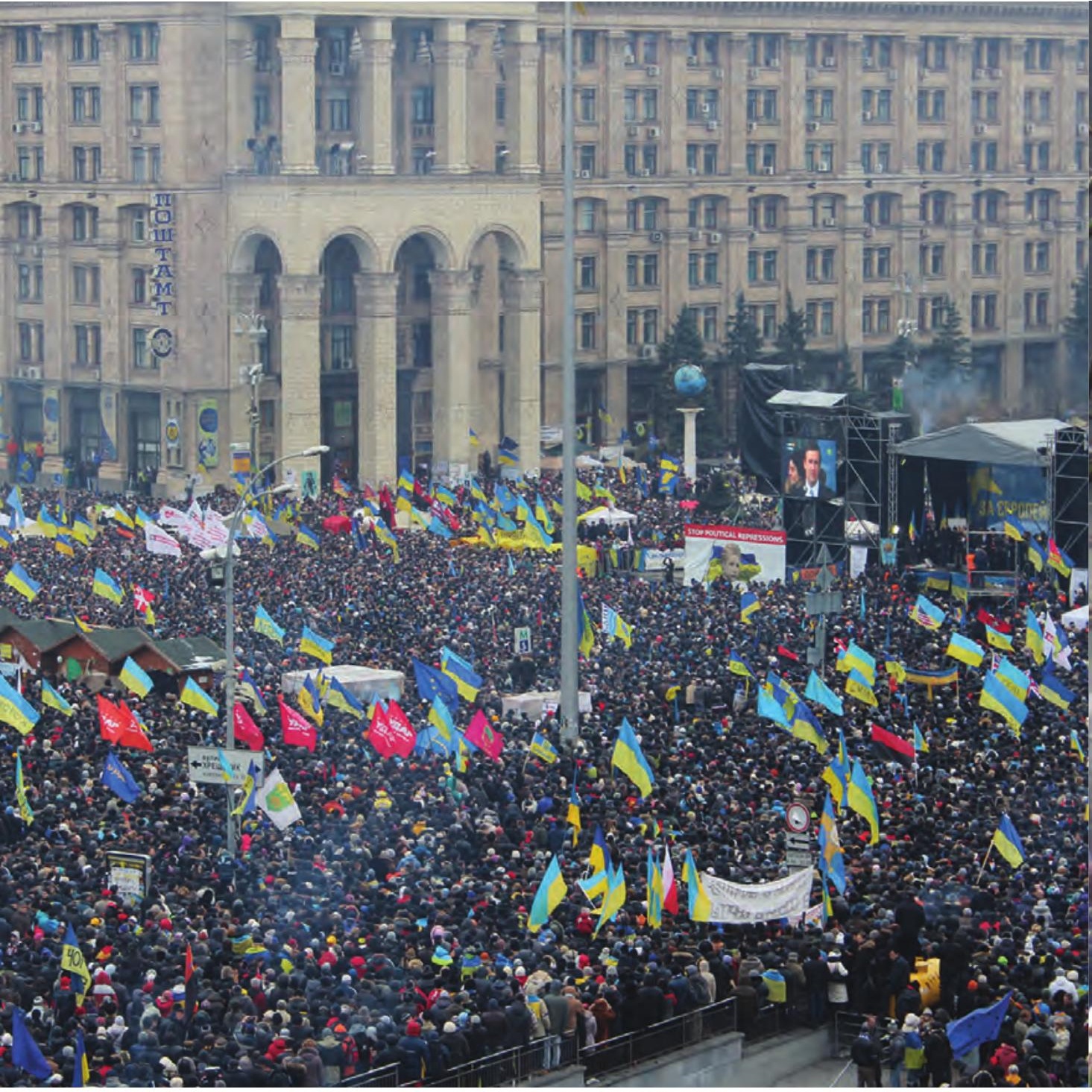

Uczestnicy tego imponującego, potężnego protestu obalili pomnik wodza bolszewickiego puczu, Lenina, który stał $w$ centrum miasta nieprzerwanie od roku 1946.
Na stronie obok:

Zapowiedź przyszłego dramatu. Na drugim planie oddziały berkutowców, 


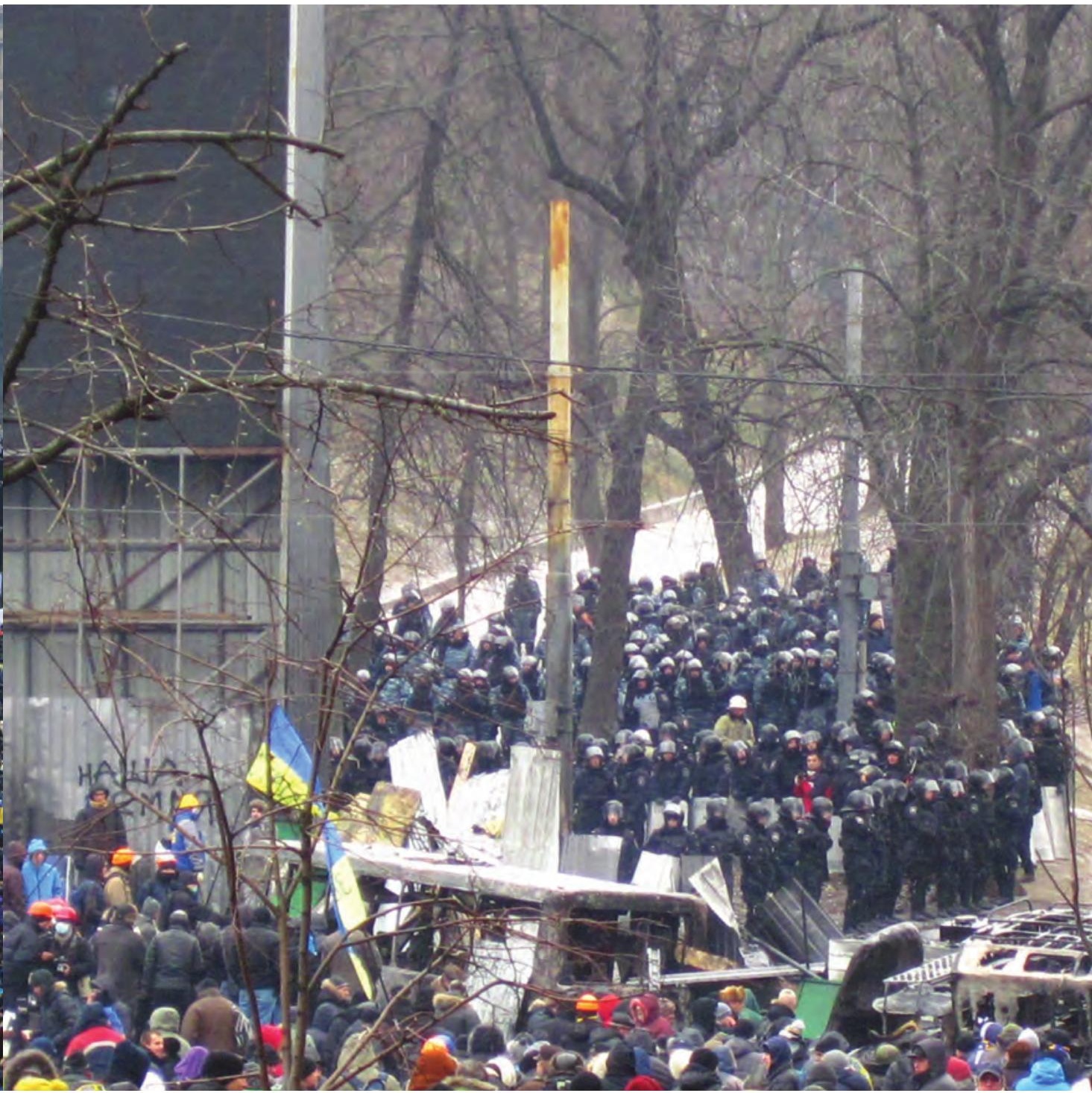

nadciągające na rogatki

Placu Niepodległości. 


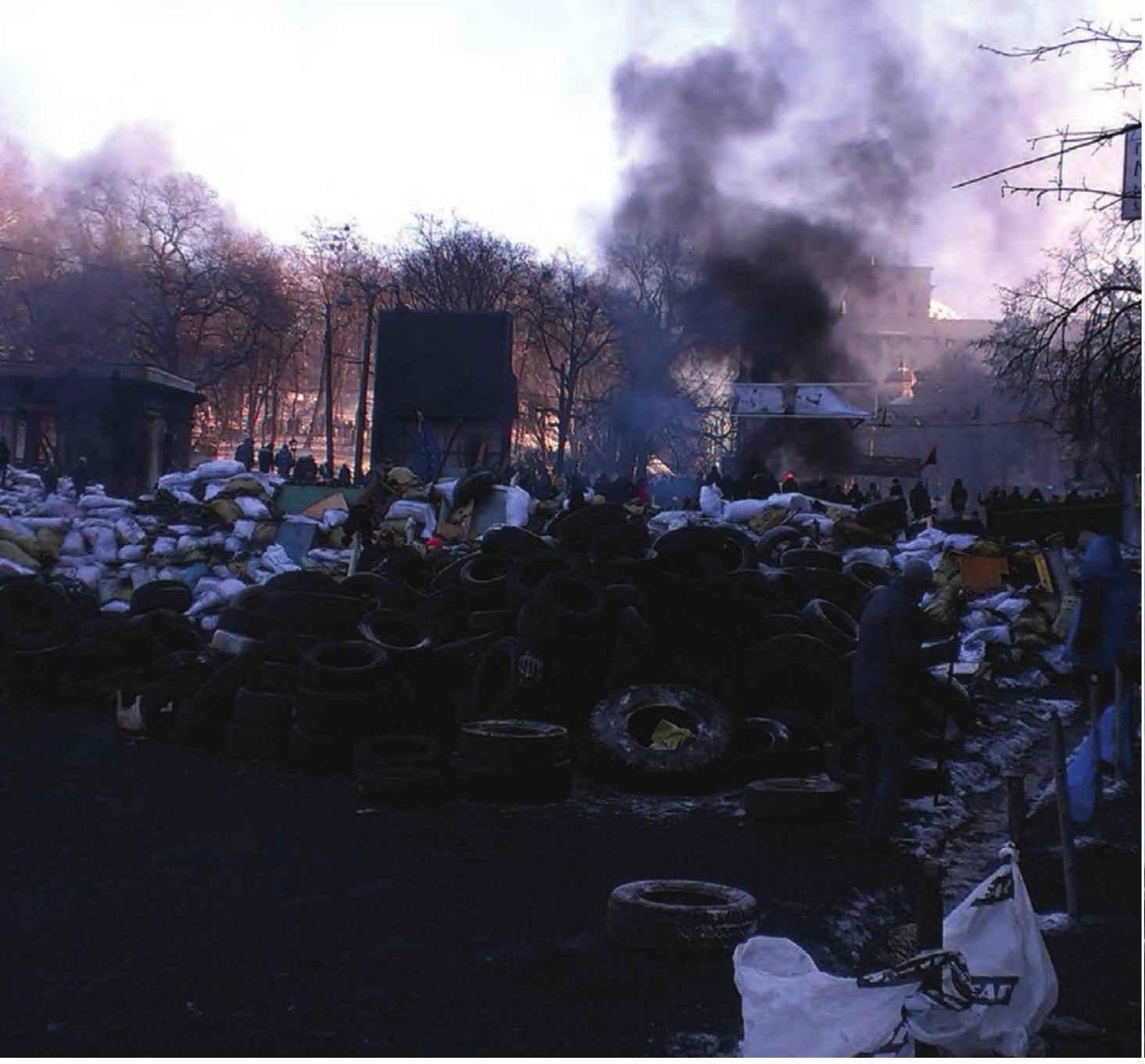

Walki z Berkutem 24 stycznia 2014 r. Nad Placem zaczyna unosić się gęsty, czarny dym ze stosów płonących opon, które podpalali bojownicy Majdanu, usiłując utrudnić berkutowcom sforsowanie barykad i wtargnięcie na Plac.
Na stronie obok:

Walczący Majdan... 

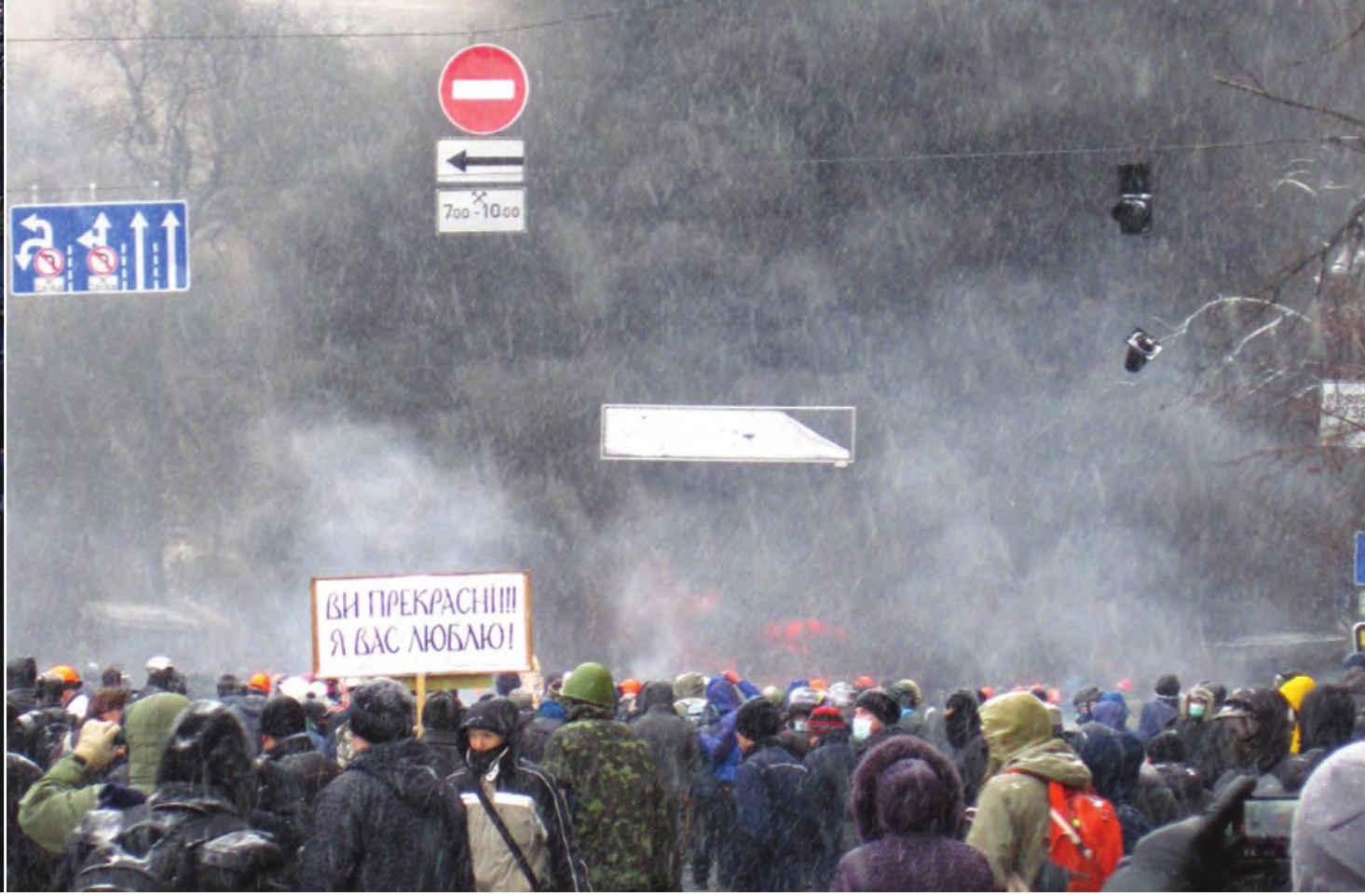

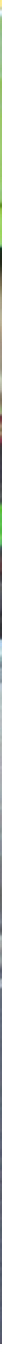

Trwają walki. Wiatr zwiewa ścianę dymu w stronę berkutowców.
Na stronie obok: Ormianin Sergij Nigojan (na pierwszym planie) zginął z rąk snajpera jako pierwsza ofiara walk na Majdanie w nocy z 21 na 22 stycznia 2014 r., stając się ikoną oporu. 


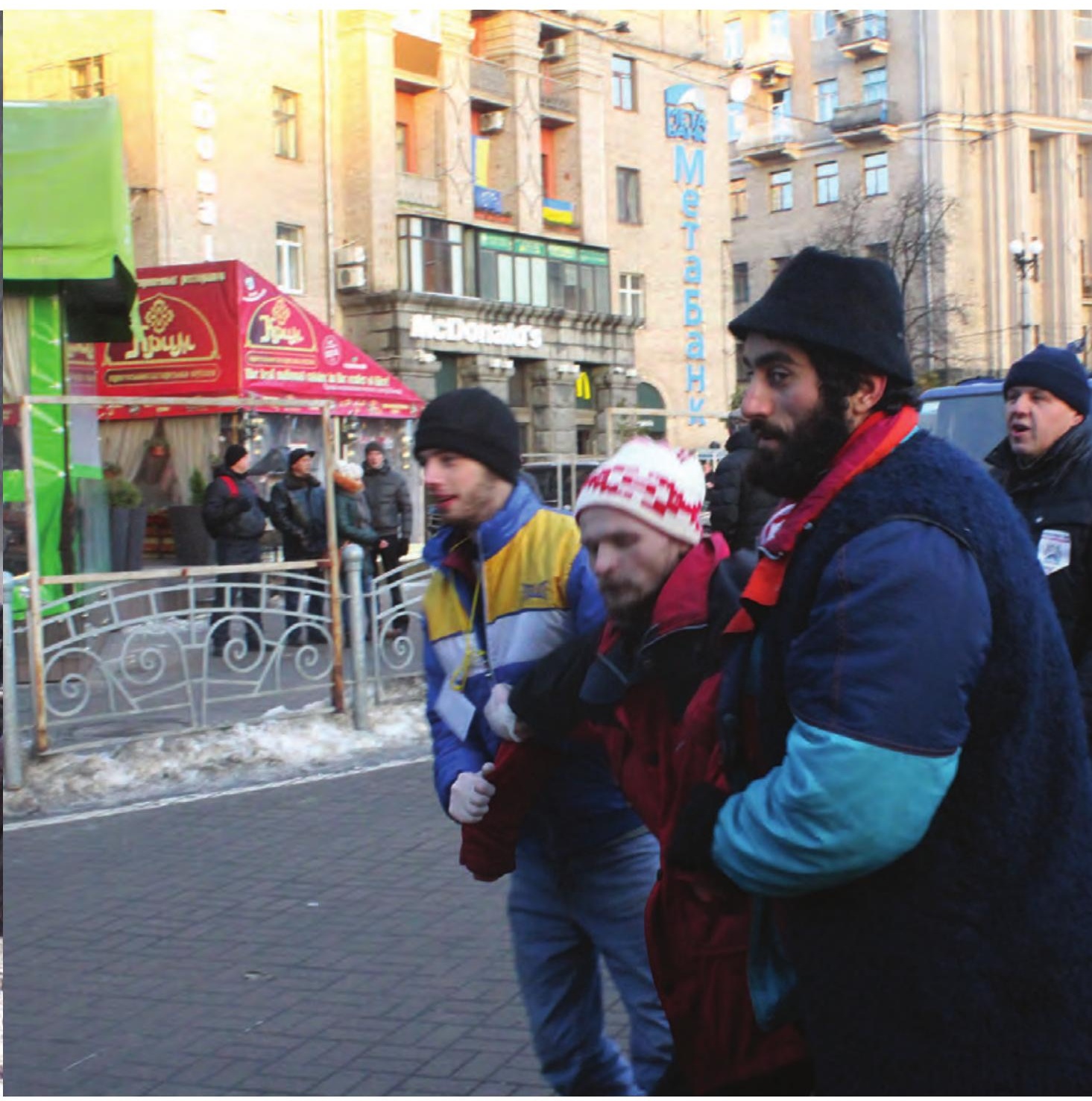




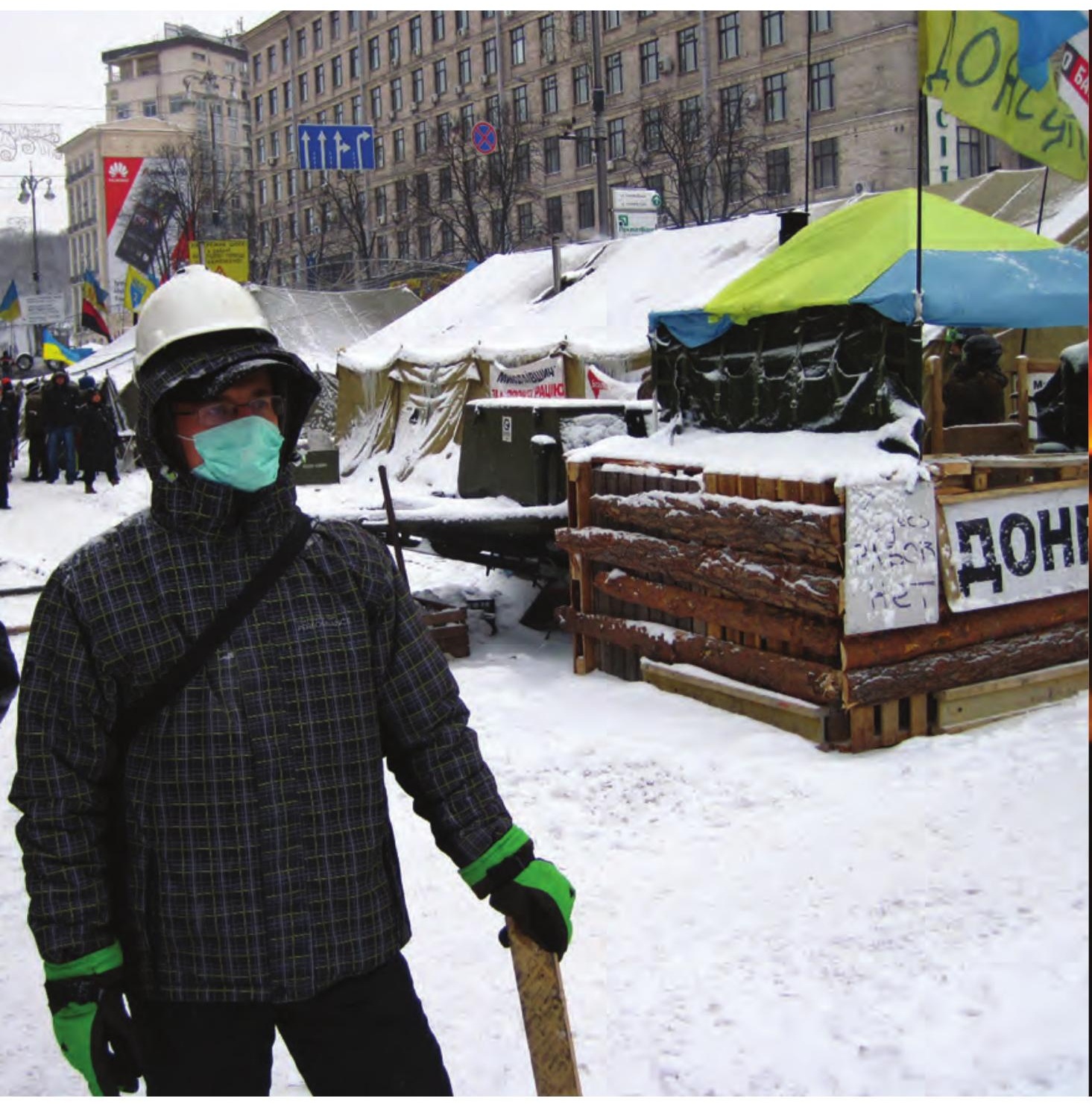

Przerwa w walkach przegrupowanie sił...
Na stronie obok:

Nocne inferno... Płonące barykady Majdanu, przedzielające bojowników od szturmujących Plac berkutowców. 


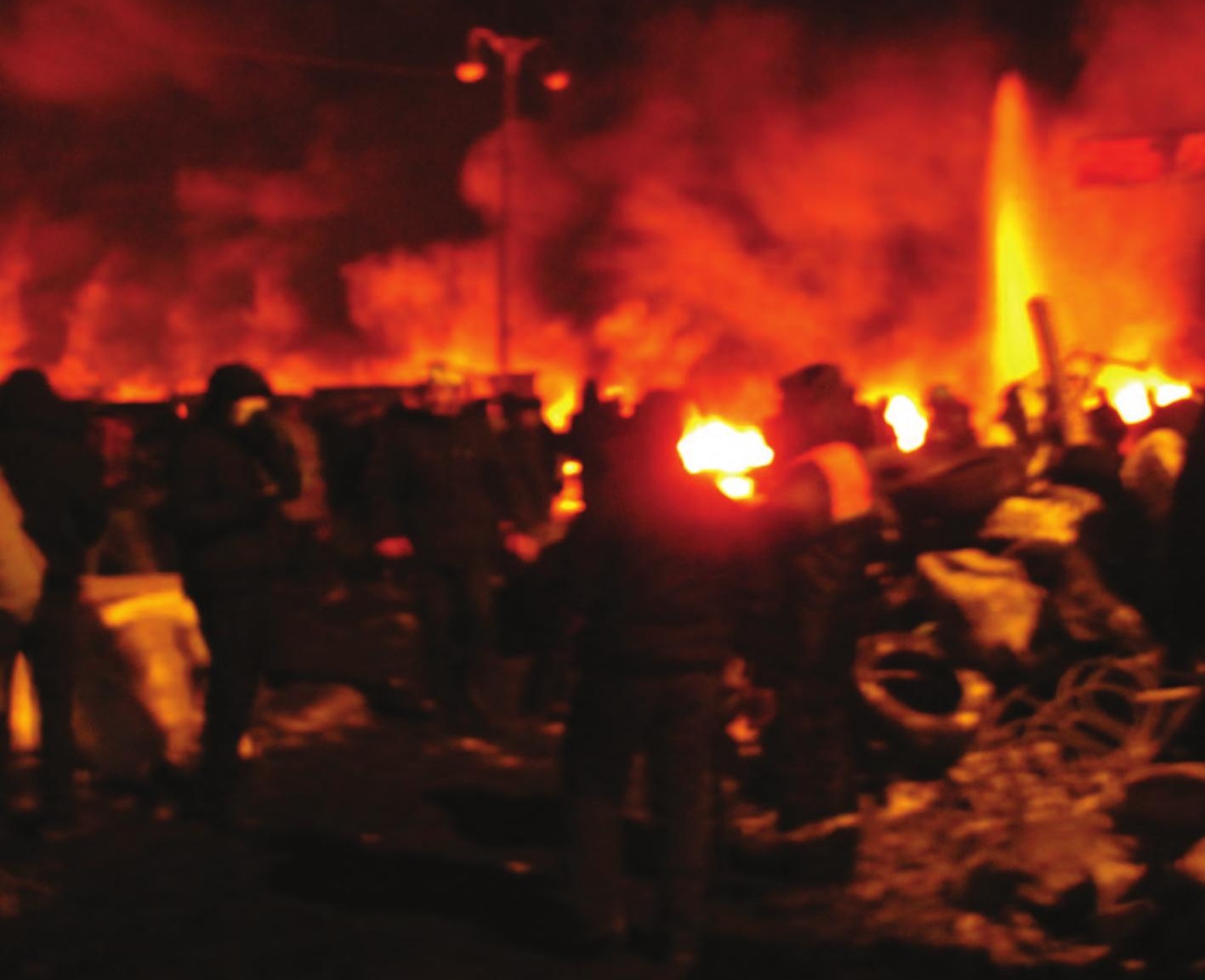

? 


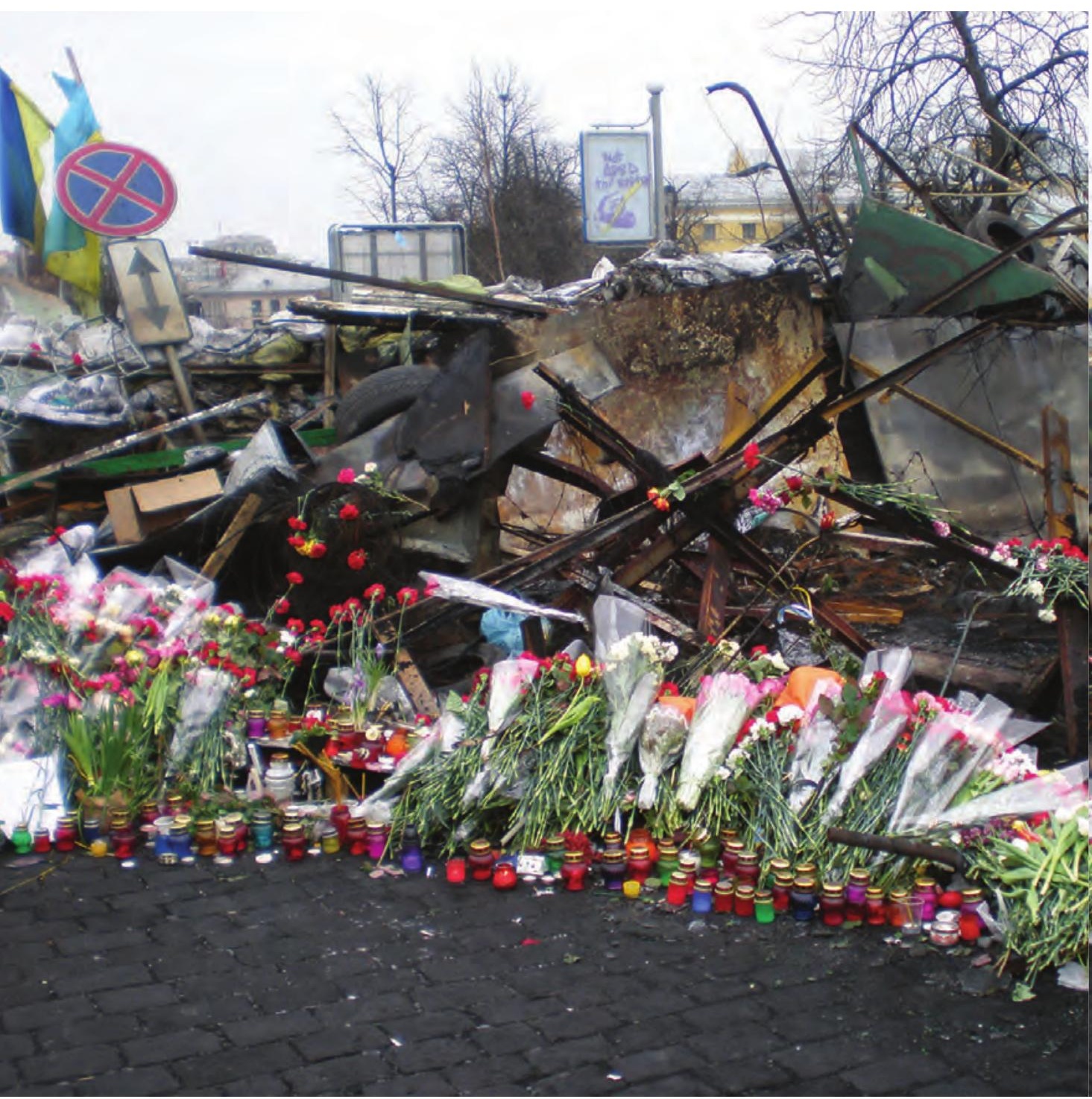

Ranek. Krajobraz po nocnej bitwie. Spalona barykada na ulicy Hruszewskiego...
Na stronie obok:

...a pod nią zapalone znicze i kwiaty, mające upamiętniać tych spośród bojowników, którzy podczas walki dołączyli do „Niebiańskiej Sotni”... 


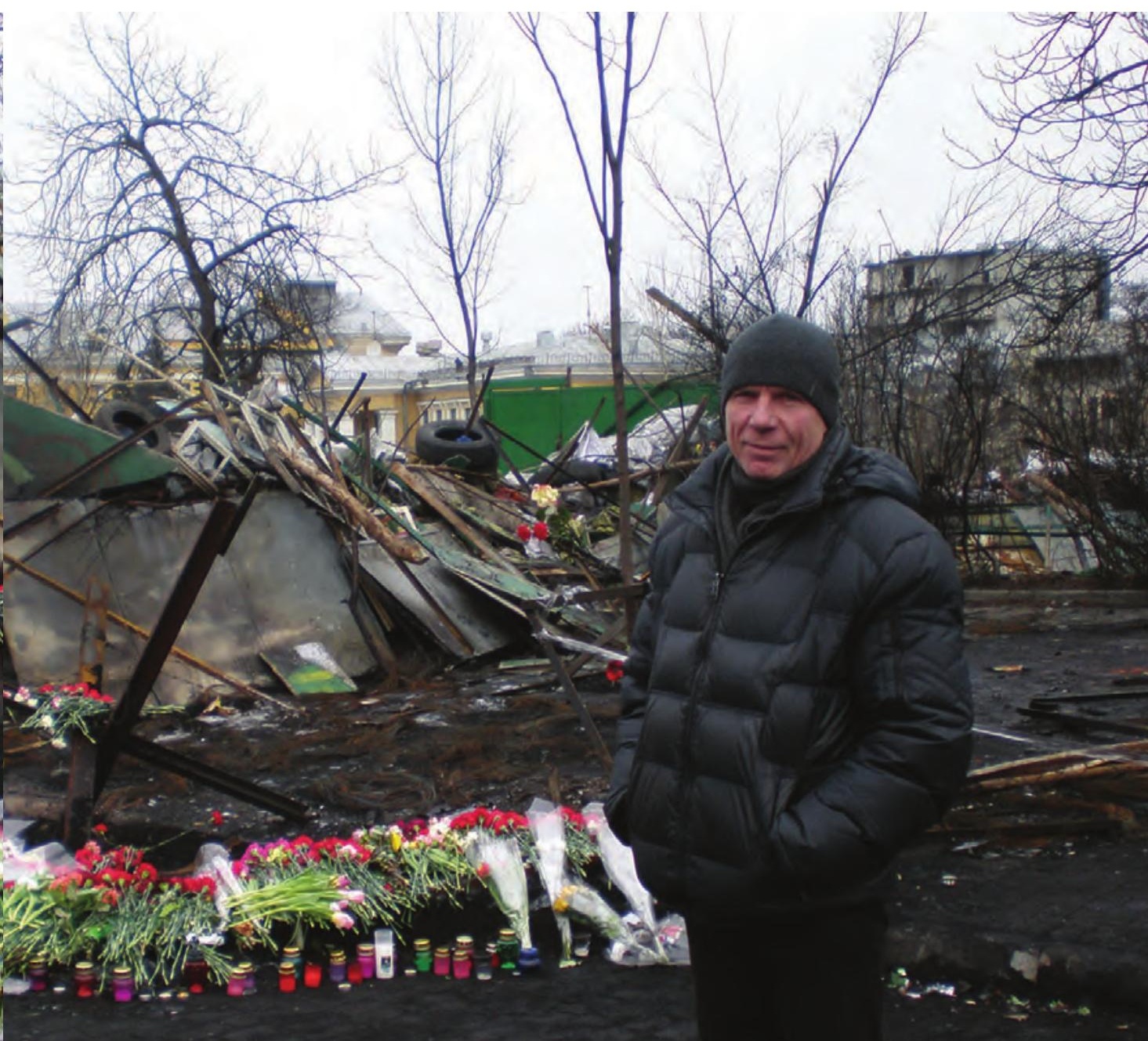




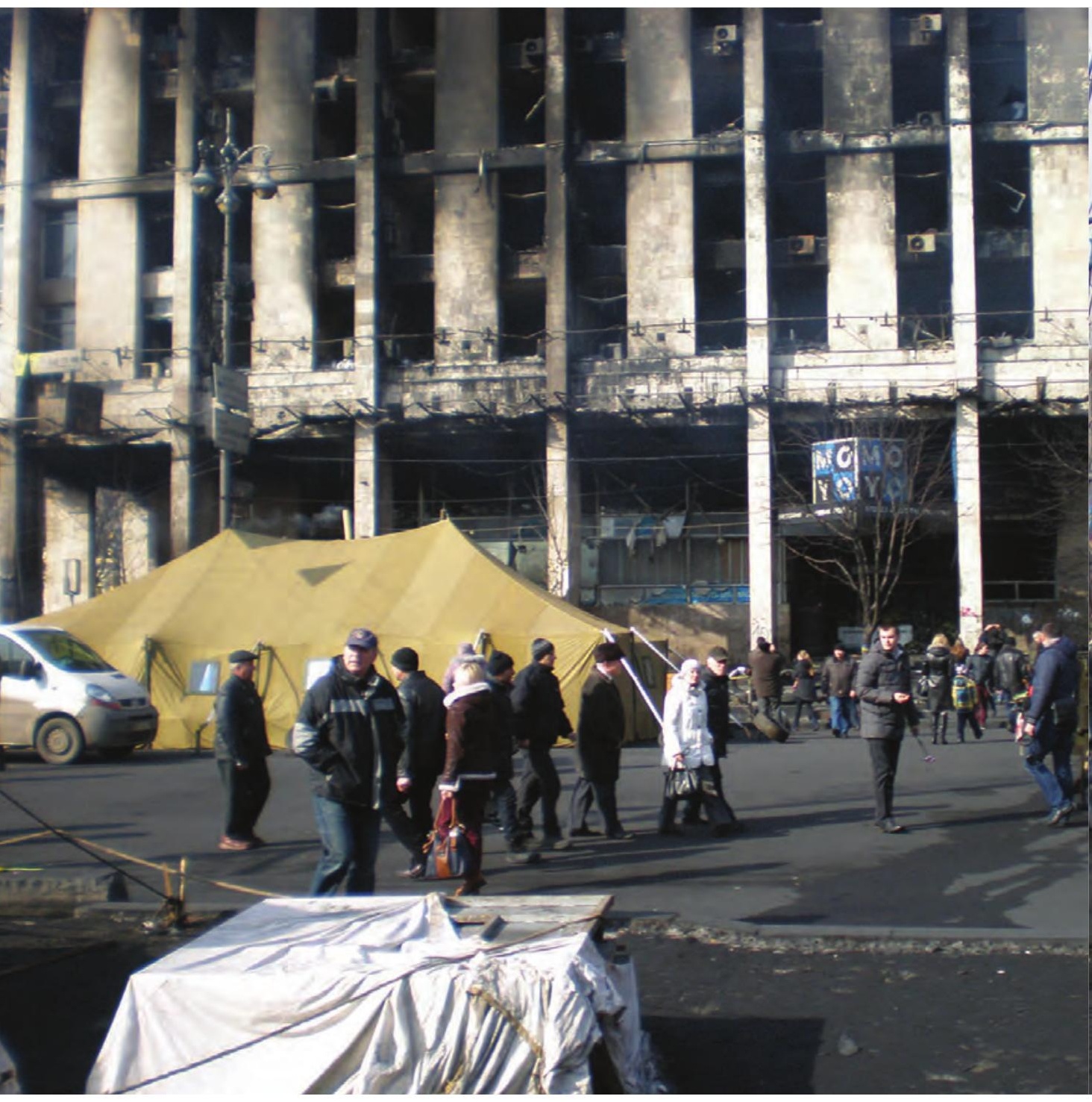

Spalona przez berkutowców podczas szturmu siedziba ukraińskich związków zawodowych...
Na stronie obok:

...w której kwaterował sztab Majdanu i dowództwo Prawego Sektora. 


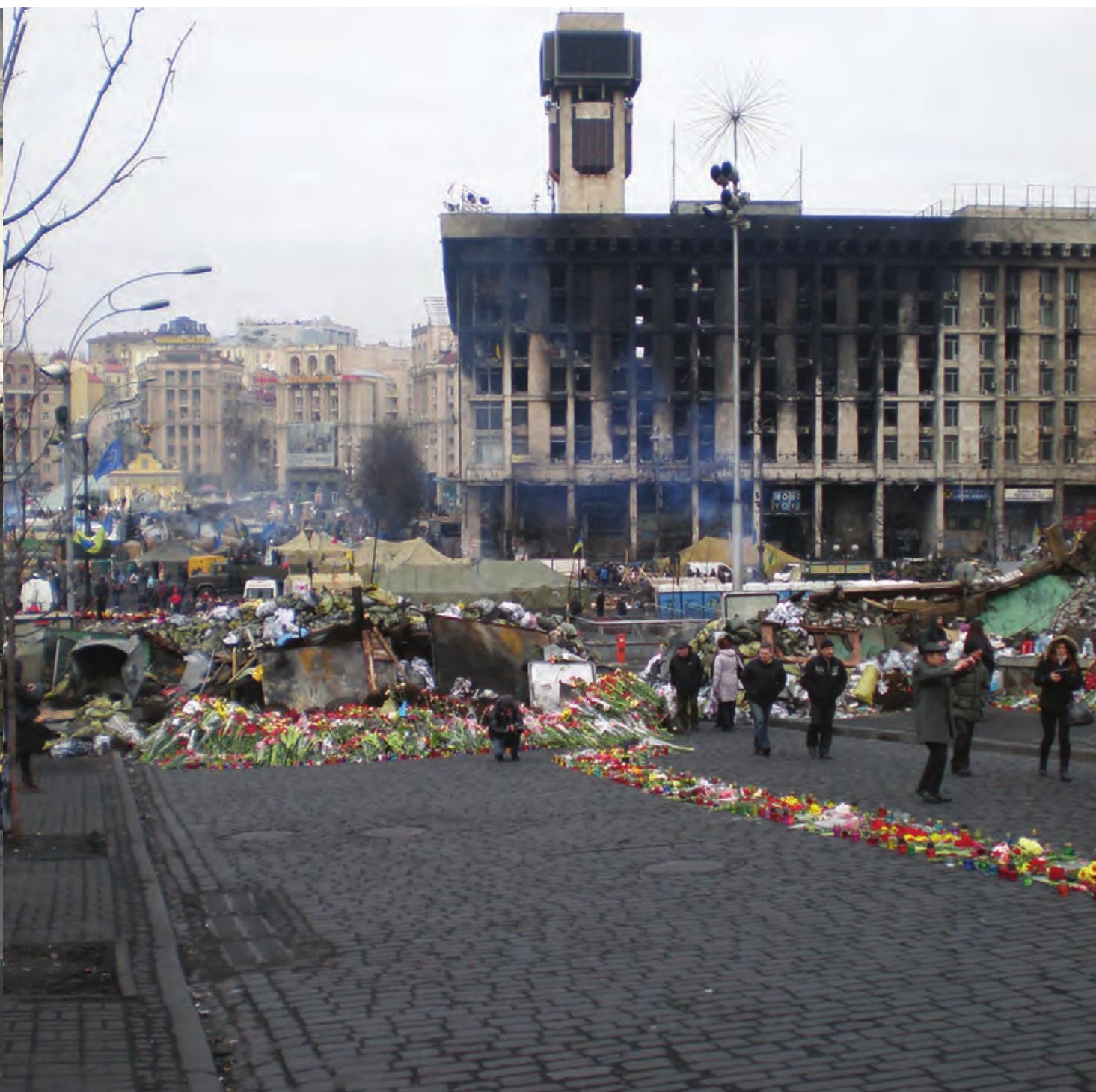




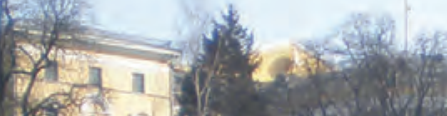

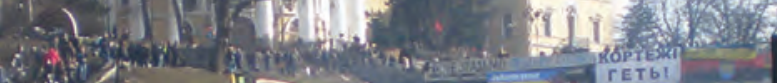

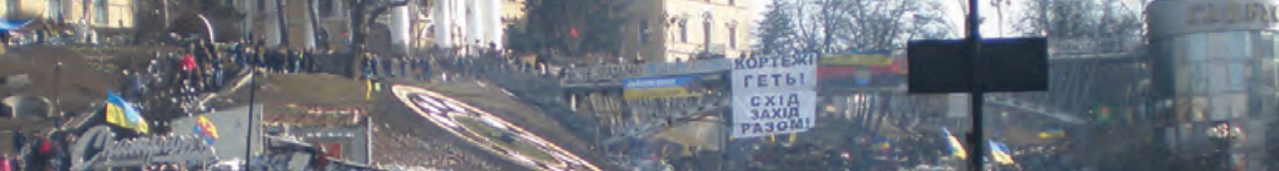

a

a.

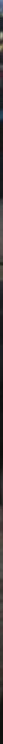

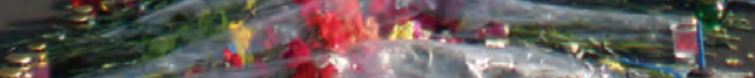

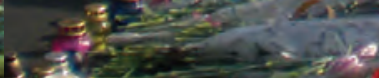

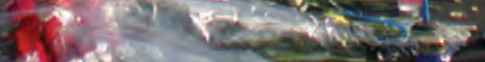




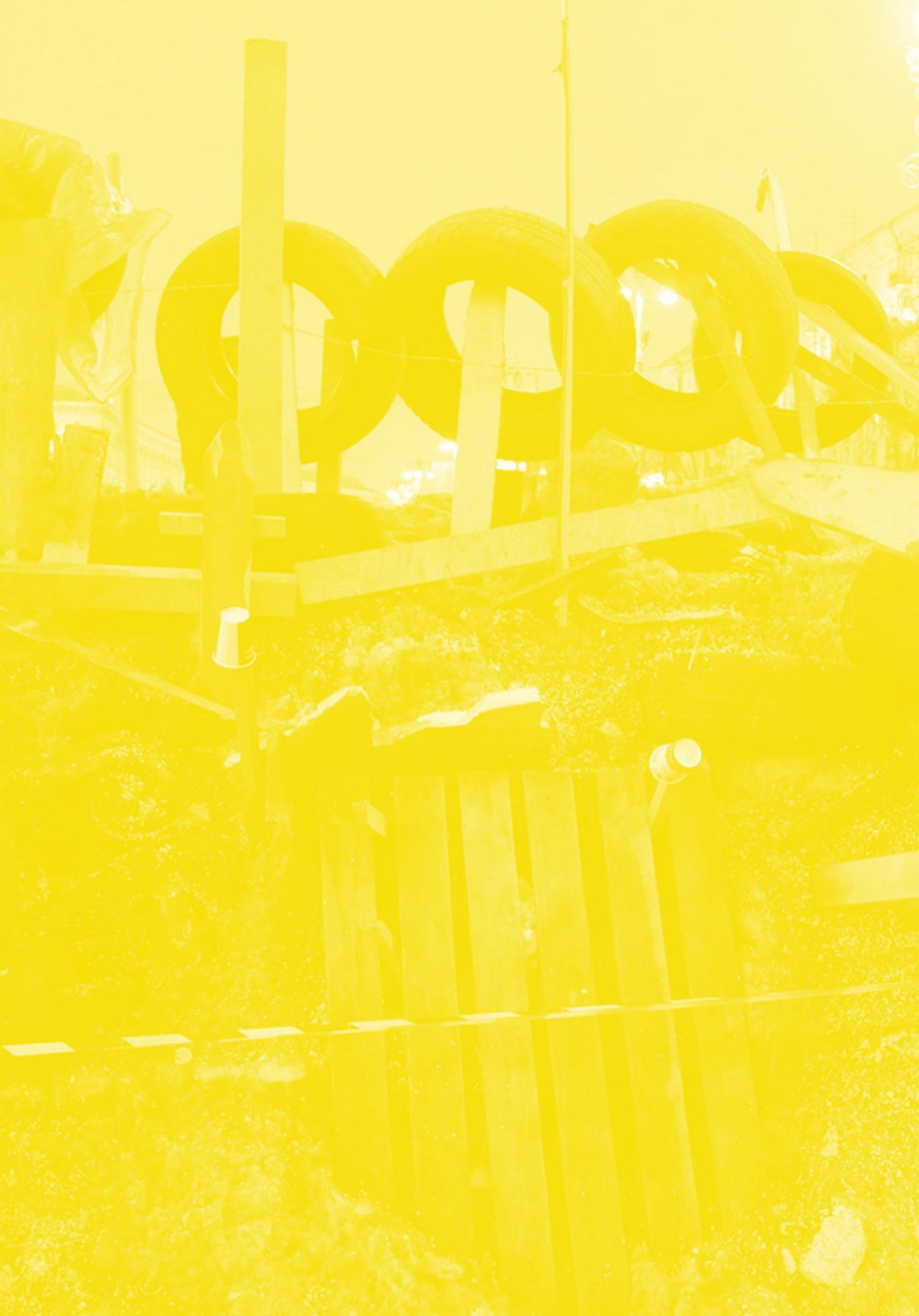


CZAS PAMIECCI 


\section{MIASTO NAMIOTÓW}

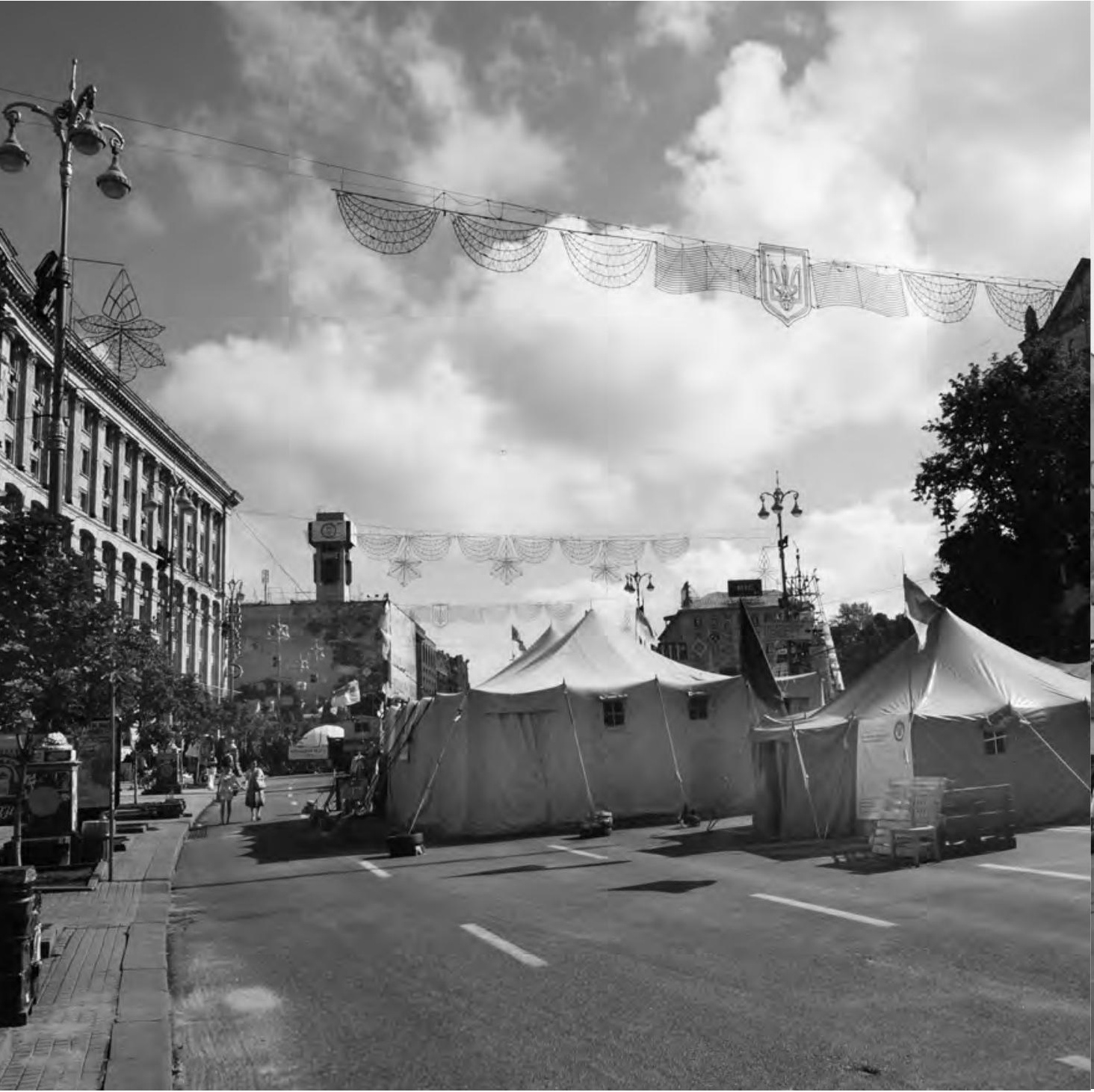

\section{Pozostałości...}

Na stronie obok:

...obozowiska „majdanowców”... 


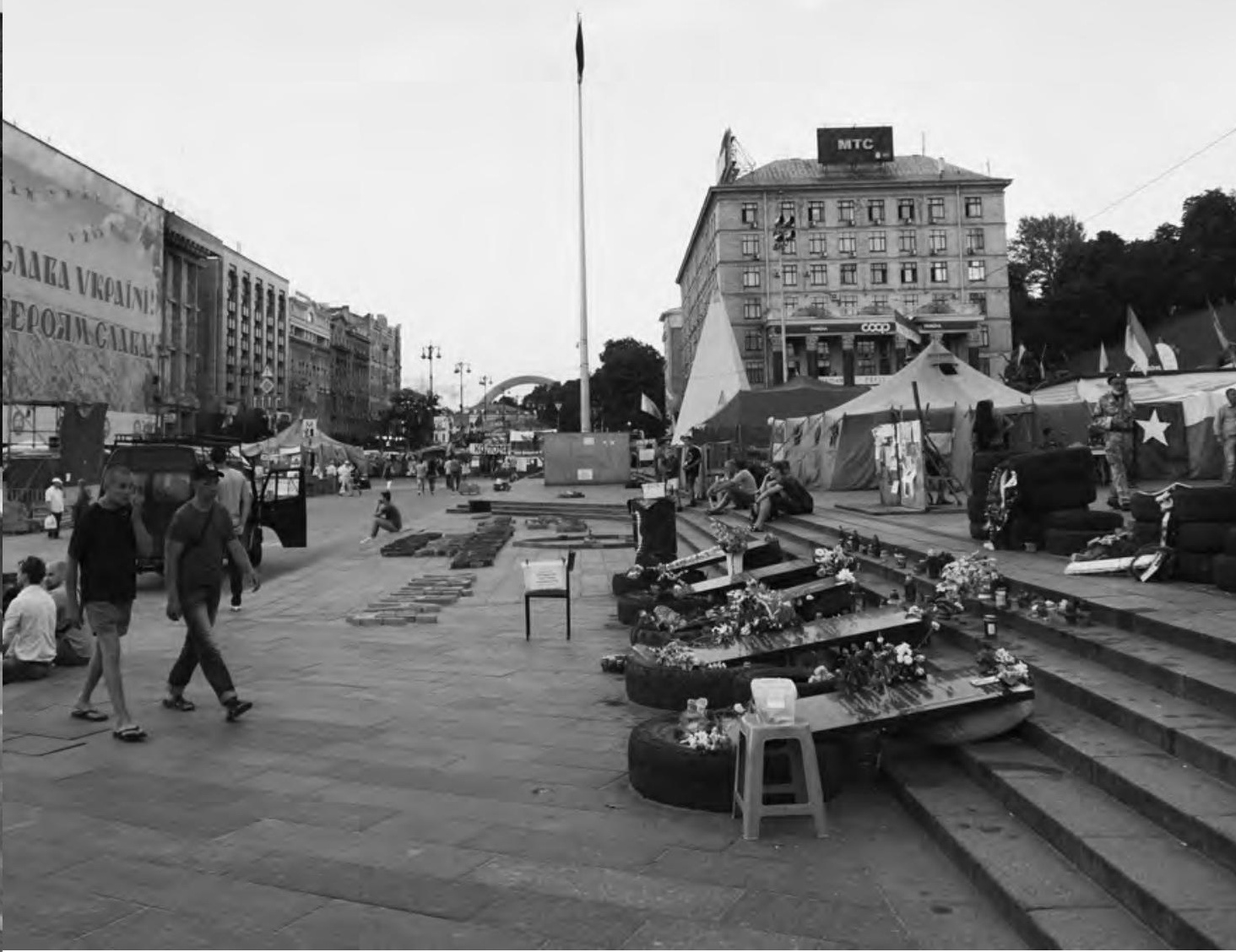




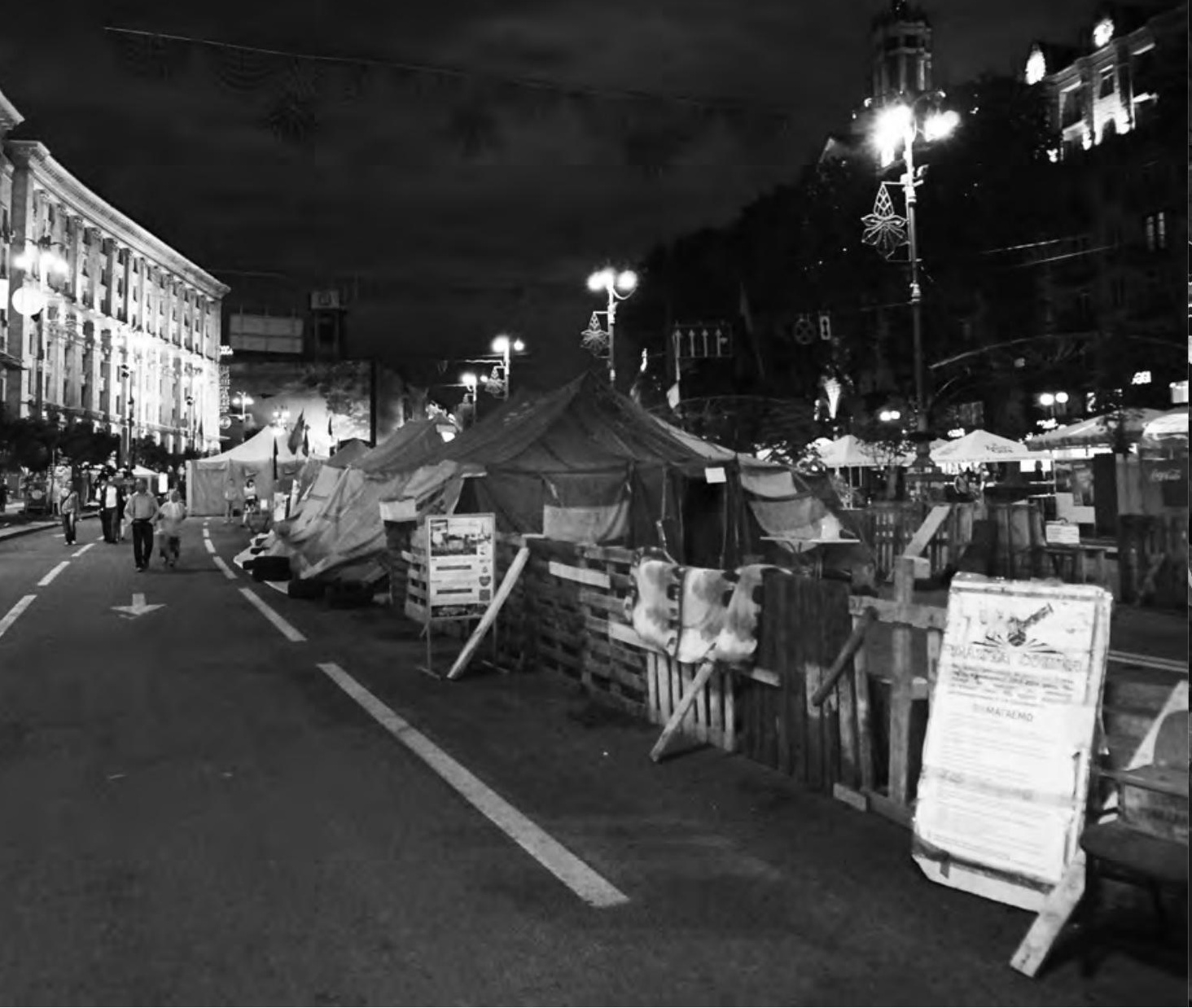

...przy znanej z walk...

Na stronie obok:

...ulicy... 


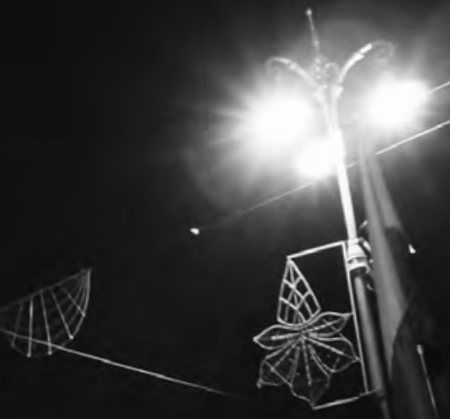

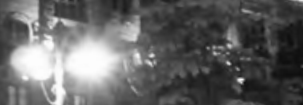

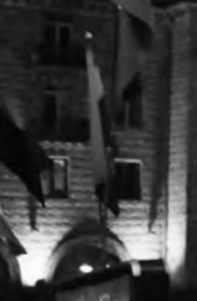

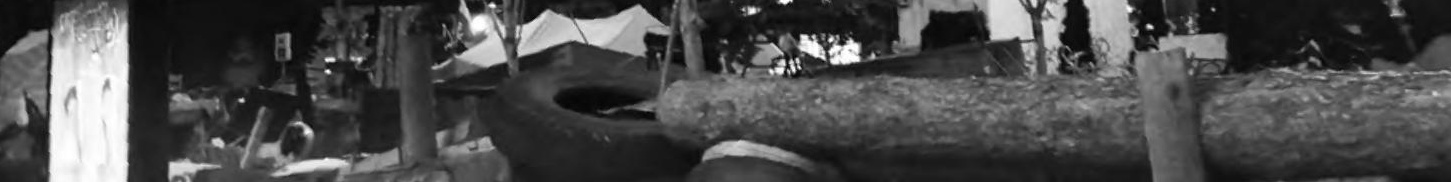
(1) का 


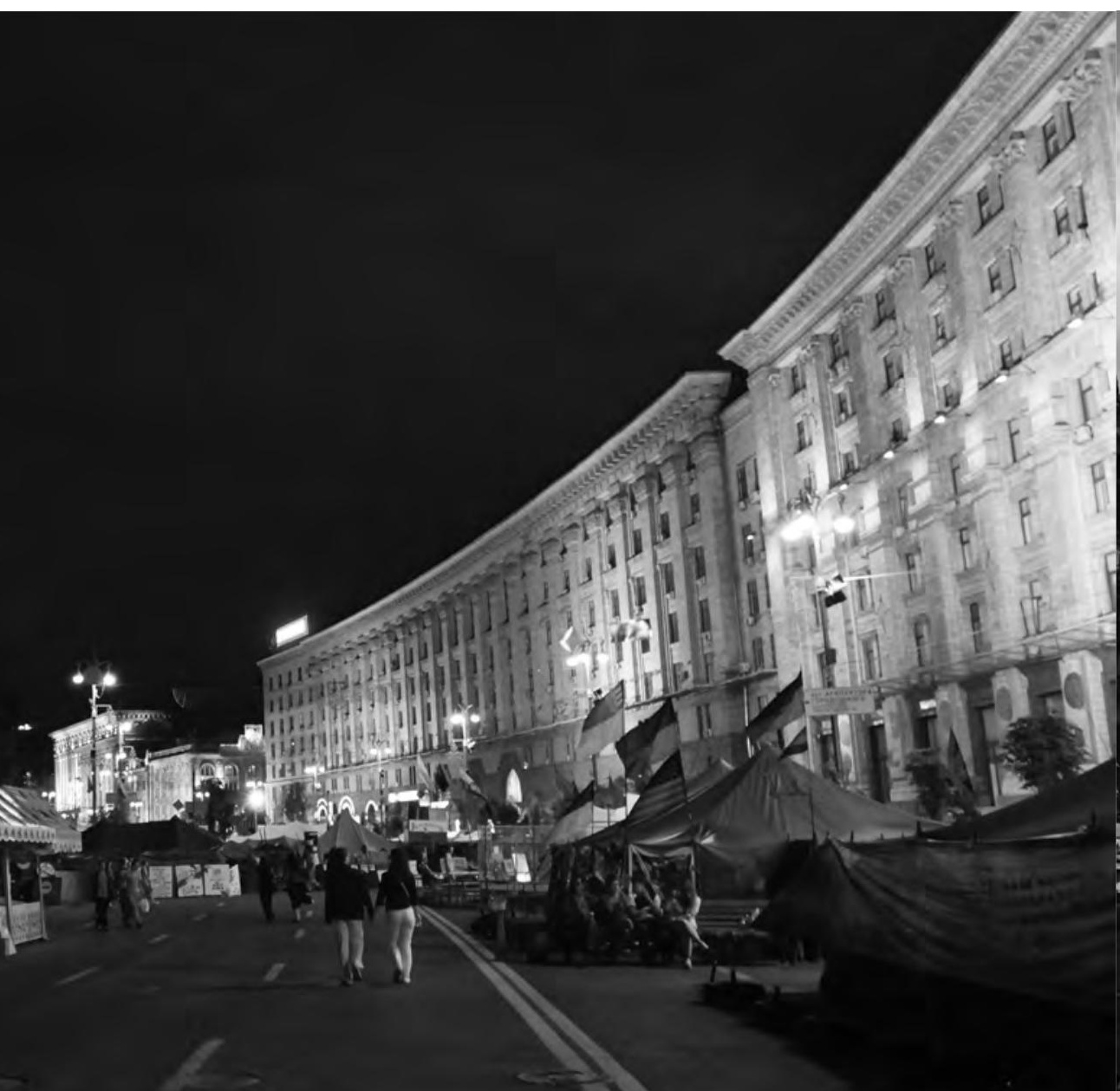

...Chreszczatyk.

Na stronie obok:

Obozowisko bojowników

Majdanu przy ulicy Horodeckiego. 


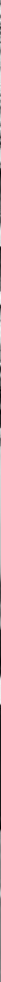




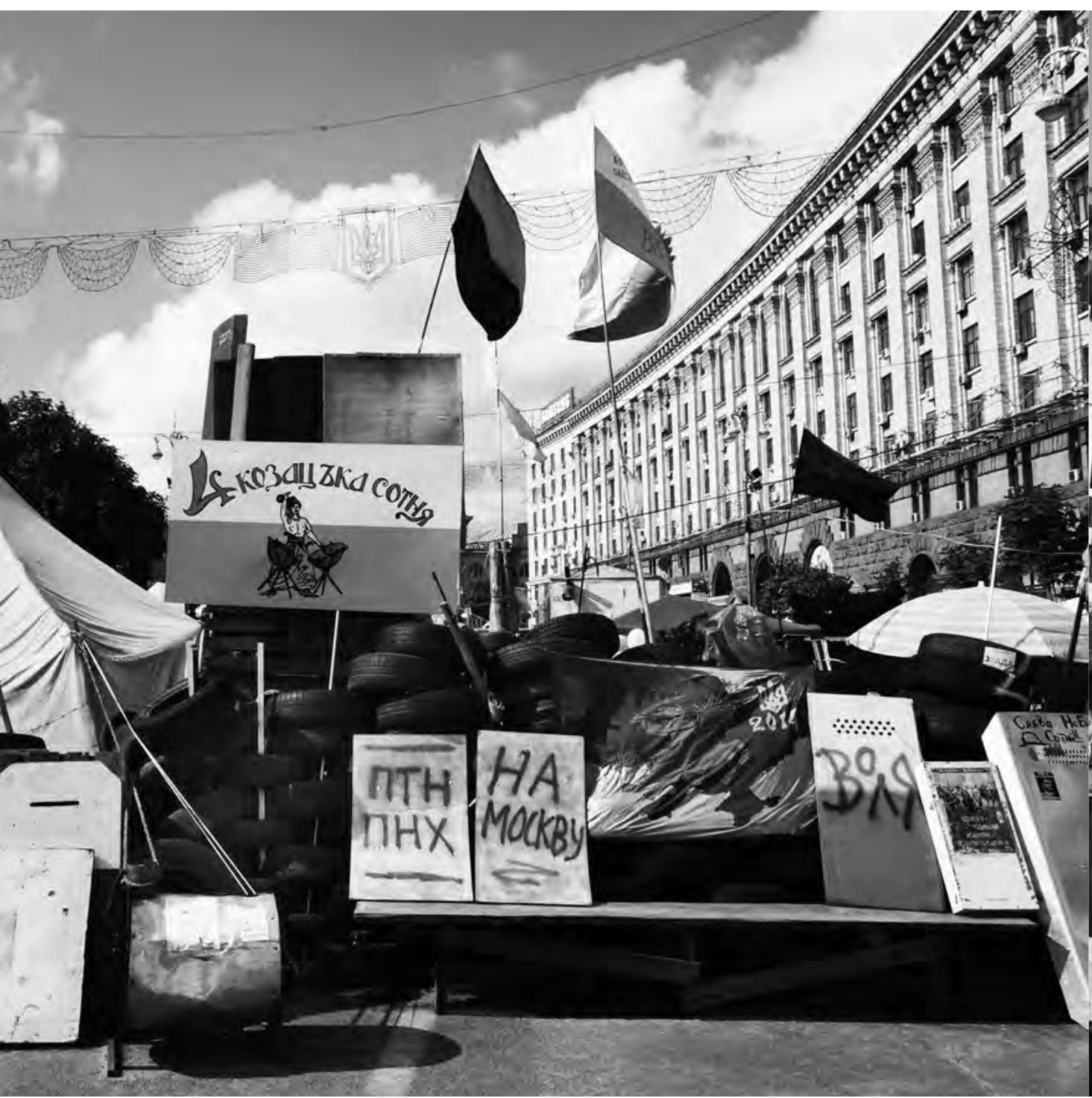

Pozostałości siedzib „majdanowców” z sotni kozackiej.
Na stronie obok:

Obozowisko bojowników

z dalekiej Kołomyi. 


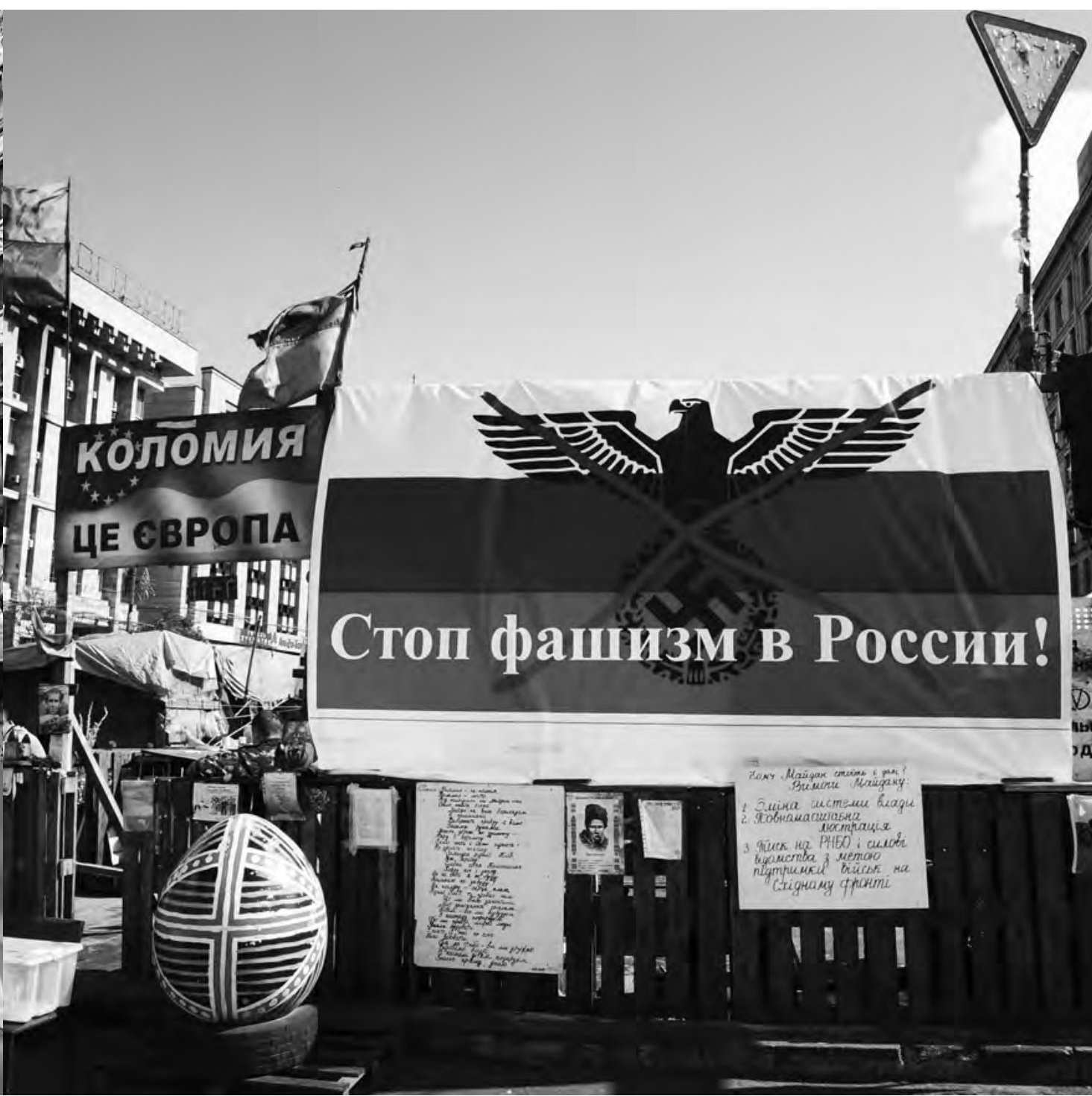




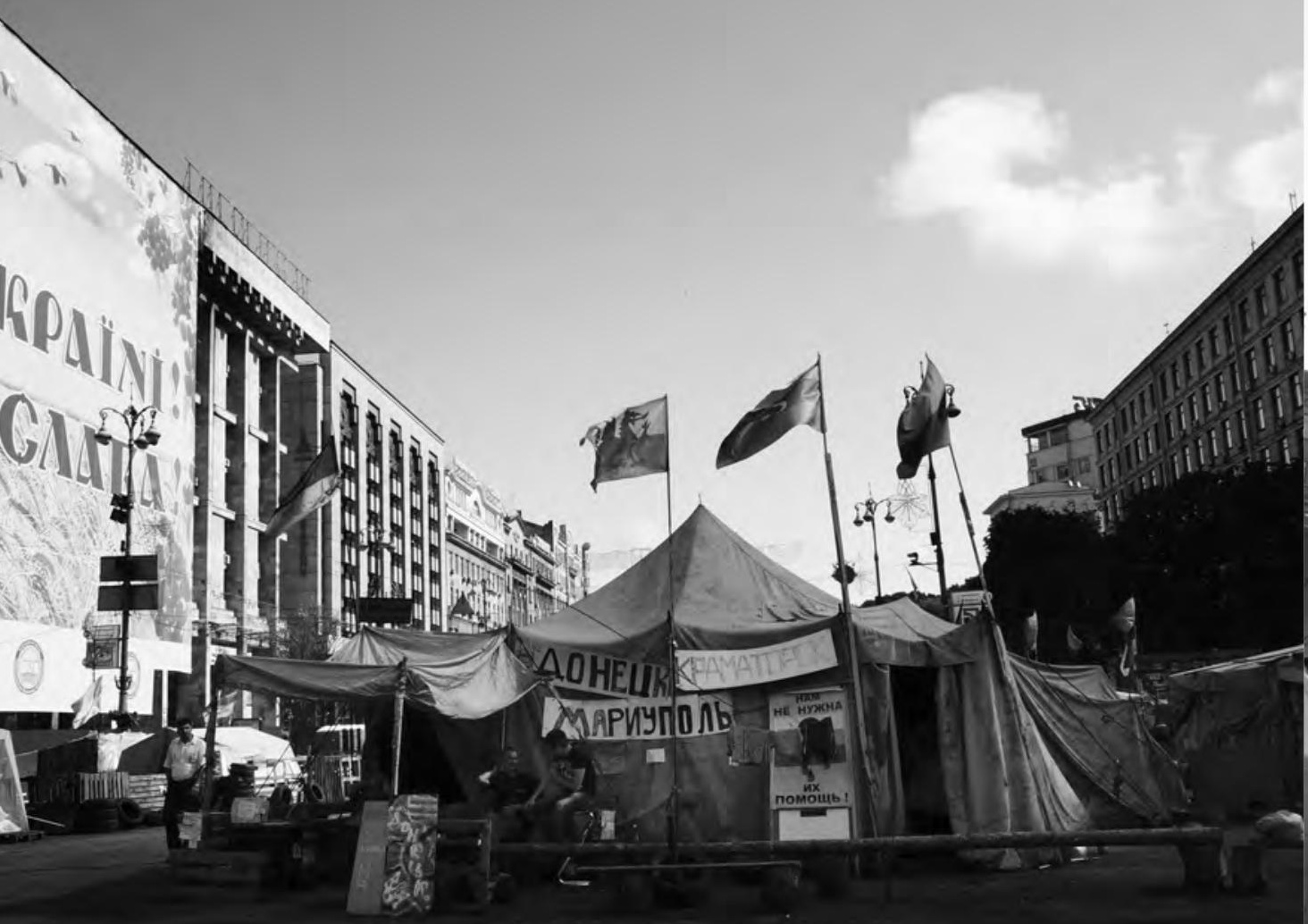

Namioty "majdanowców" $z$ regionu donieckiego, który miał rychło paść ofiarą rosyjskiej agresji
Na stronie obok:

Pozostałości obozowisk... 


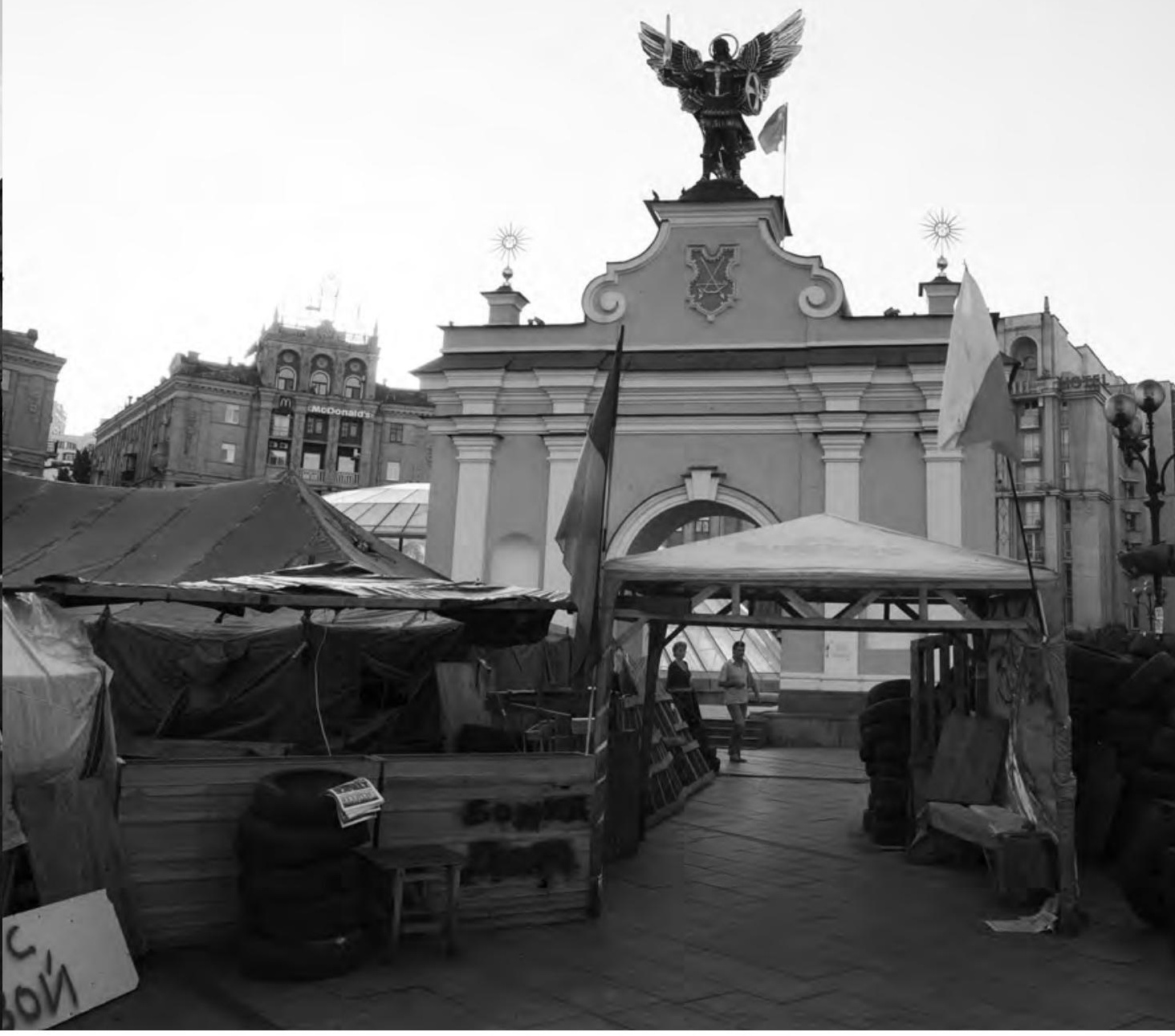




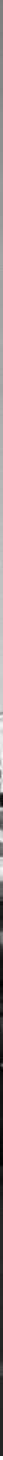

...na Placu Niepodległości...

\section{Na stronie obok:}

...w dzień... 


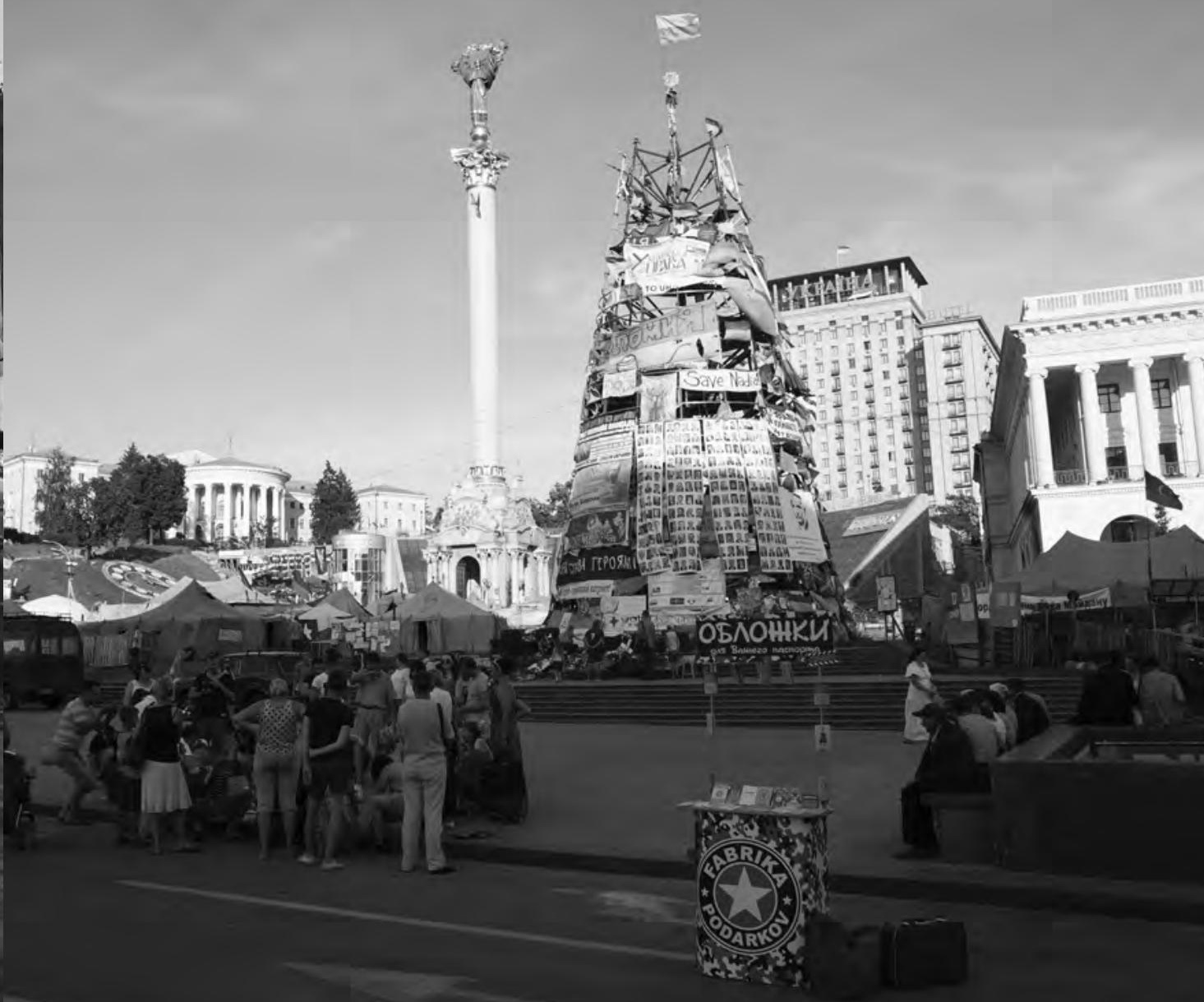




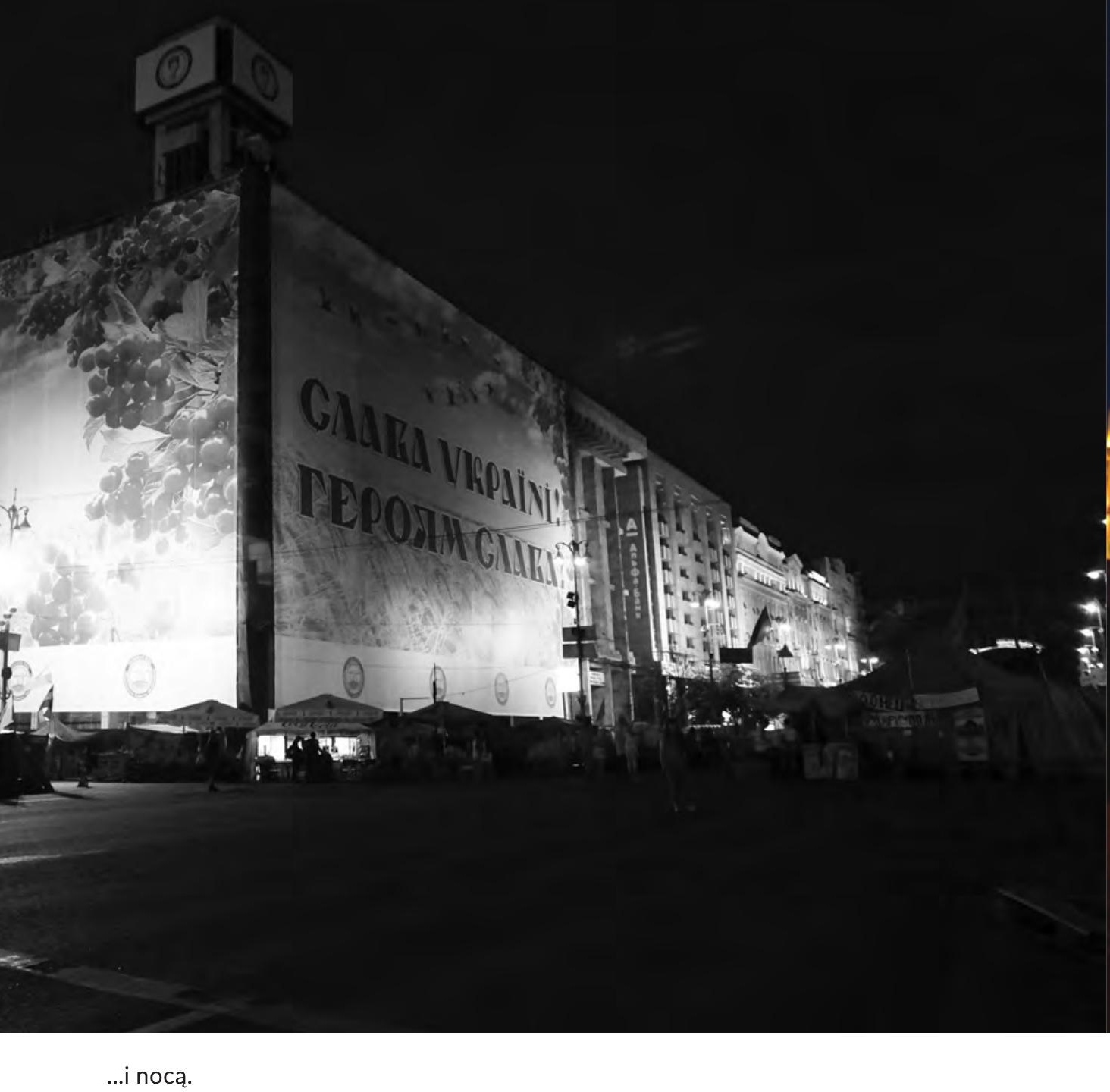

\section{Na stronie obok:}

Słynna scena Majdanu,

która ocalała z walk. 


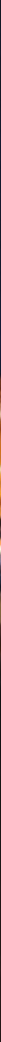




\section{NA SZLAKU BARYKAD}

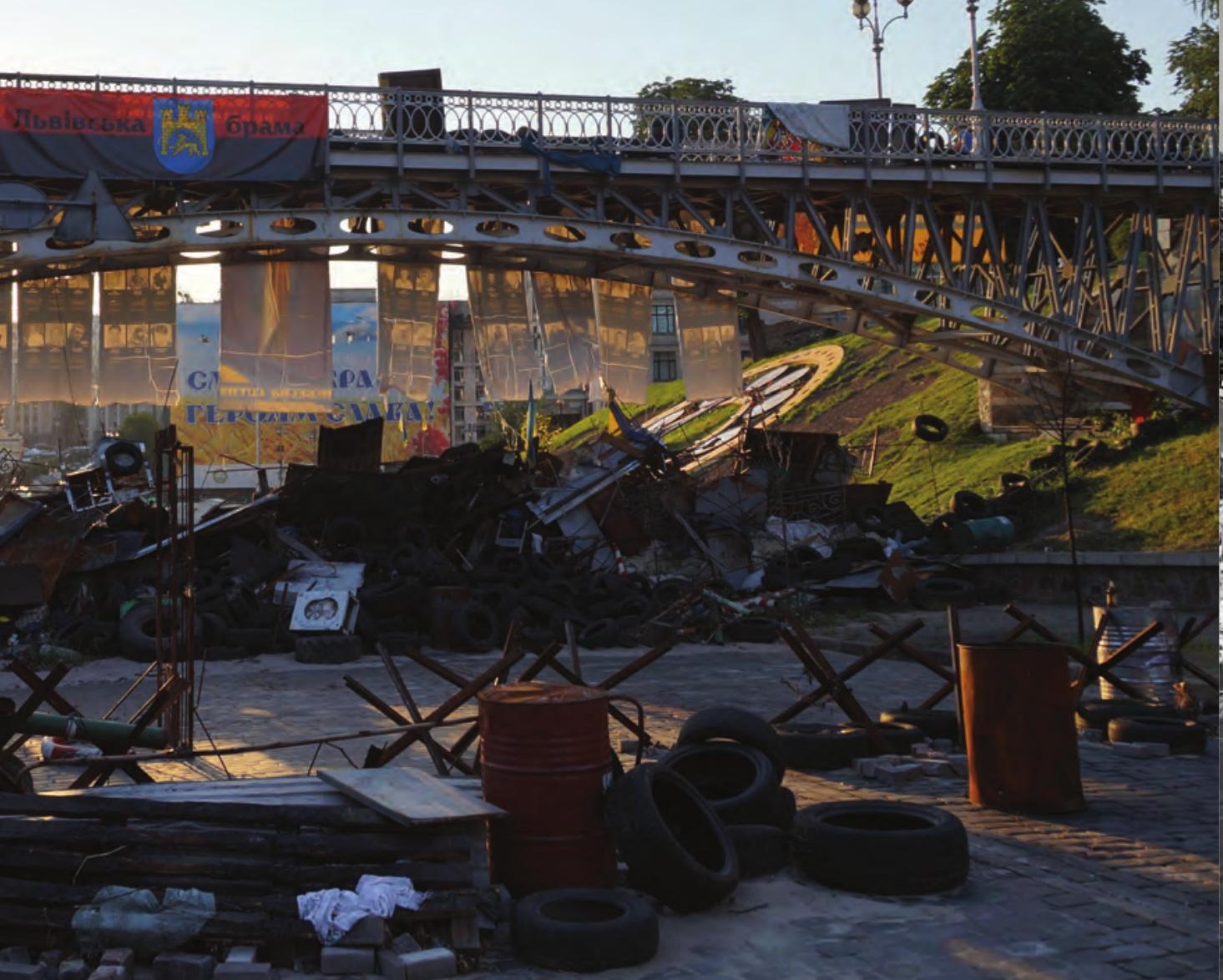

Jedna z ostatnich pozostatych po walkach barykad na ulicy Instytuckiej przy słynnym kijowskim Kwietnym Zegarze. Po przeciw- nej stronie mostu wiszą wizerunki bojowników Majdanu, poległych podczas starć z Berkutem.

\section{Na stronie obok:}

Widok na kolejną nierozebraną jeszcze barykadę na ulicy Instytuckiej po przeciwnej stronie mostu. 


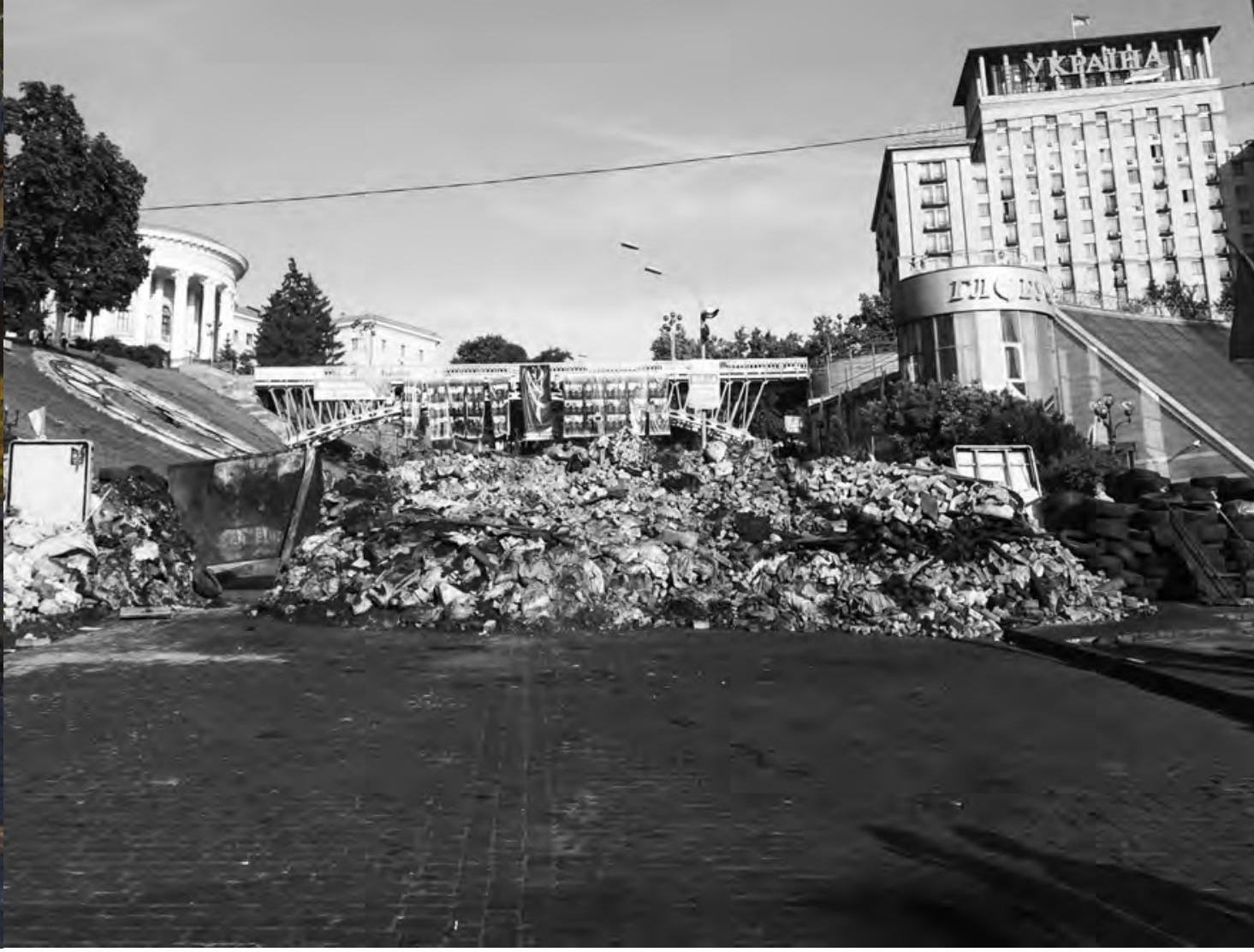




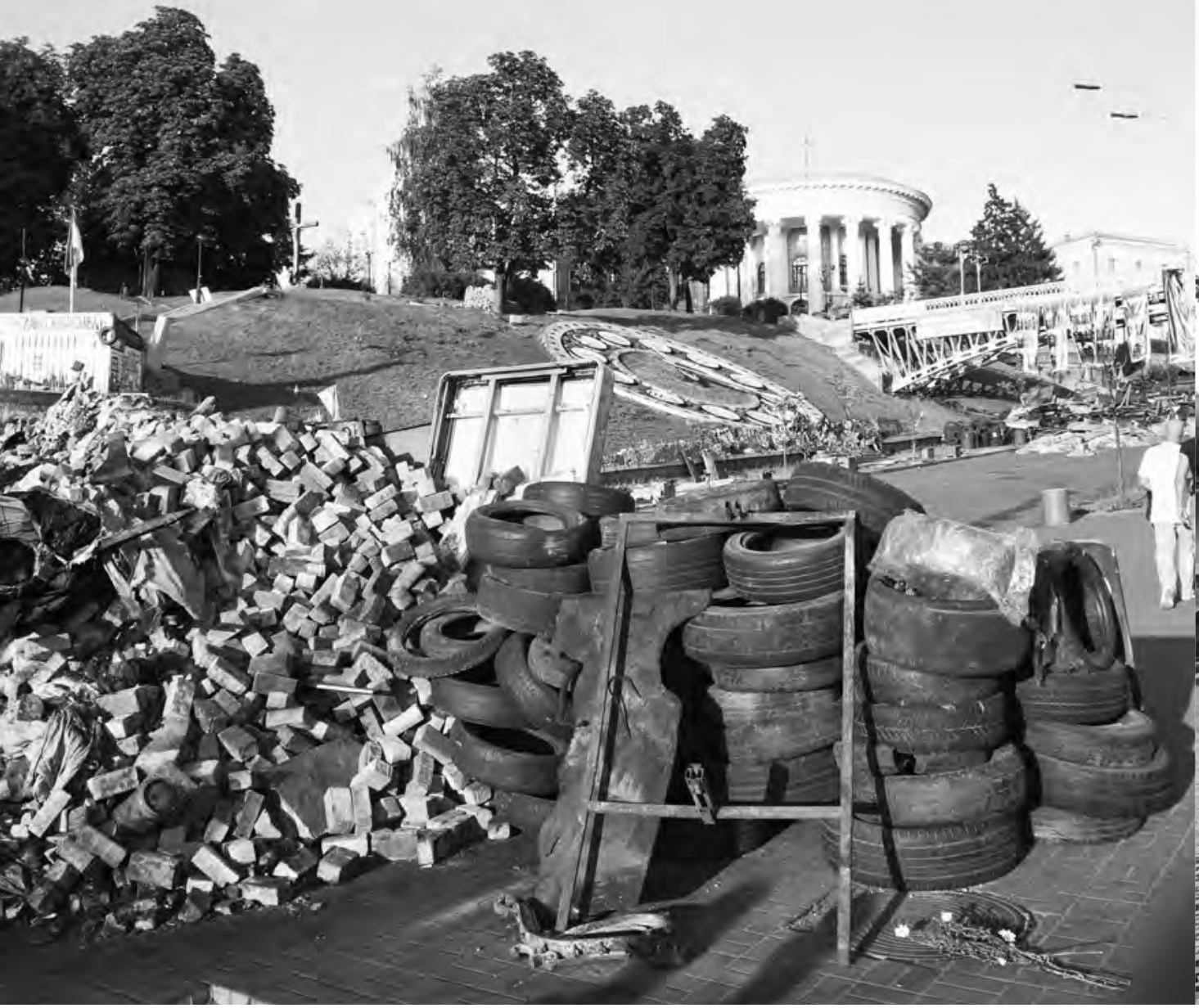

Ta sama barykada (ulica Instytucka). Widać już rezultaty prac rozbiórkowych i porządkowych.
Z pomnika chwały bohaterów Majdanu pozostało już niewiele...
Na stronie obok:

I znowu po drugiej stronie mostu na Instytuckiej... 


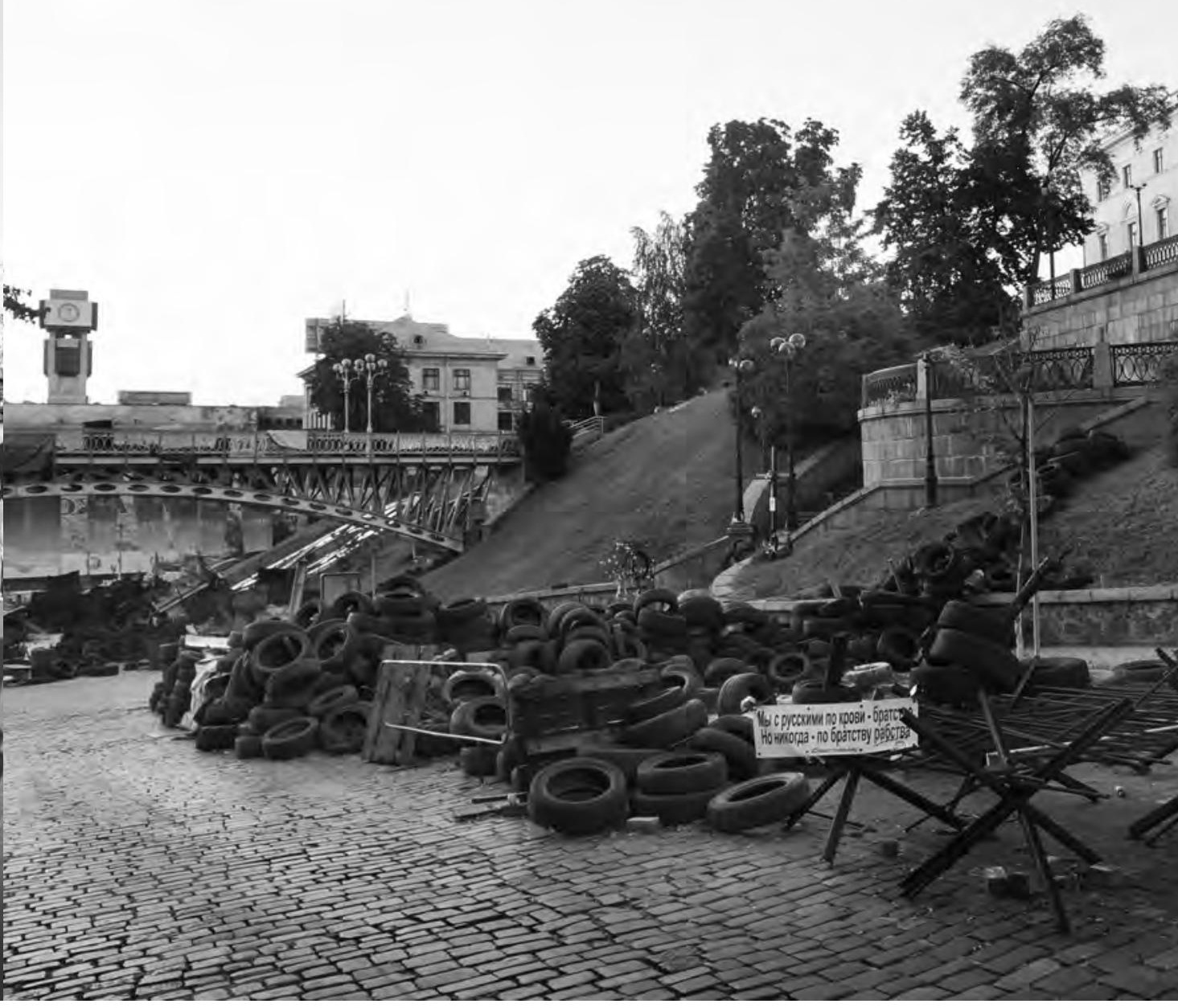




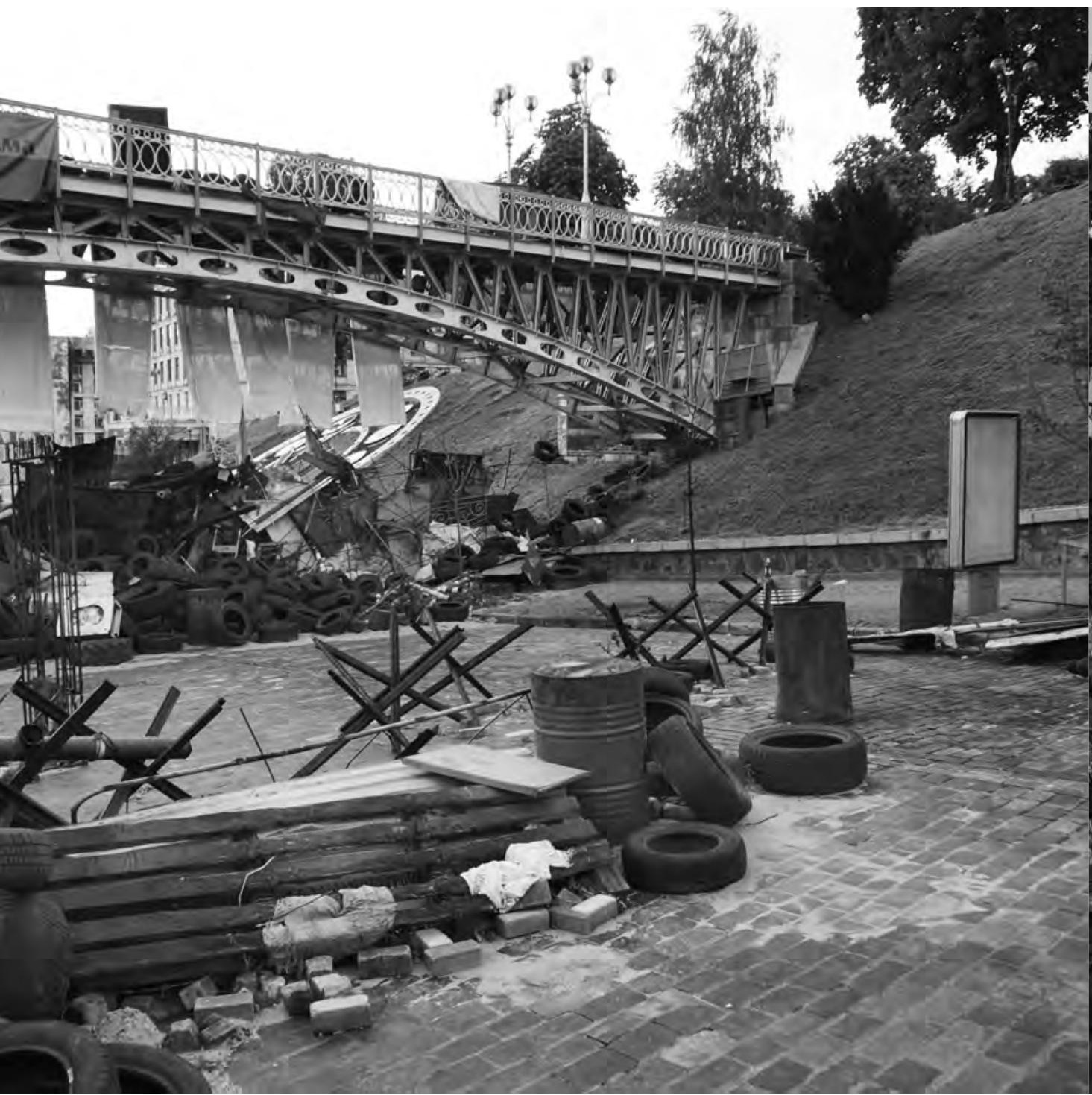

Porozsuwane resztki bary- mochodów i pojazdów kad i metalowych kozłów opancerzonych... skutecznie utrudniających szturmy berkutowców nawet te $z$ użyciem sa-
Na stronie obok: ...i wszędzie stosy opon, które przygotowano do spalenia na wypadek ataku sił milicyjnych. 


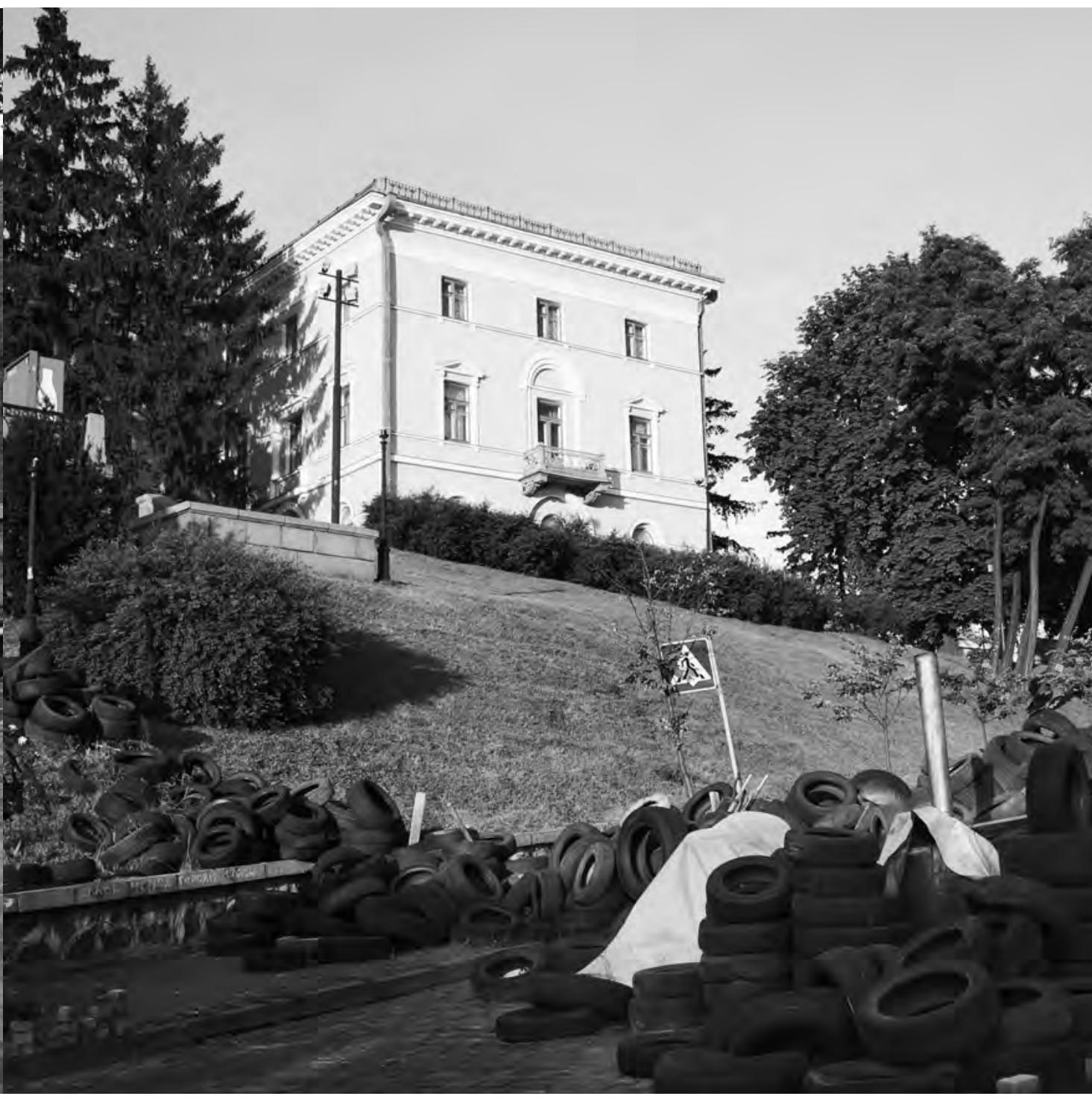




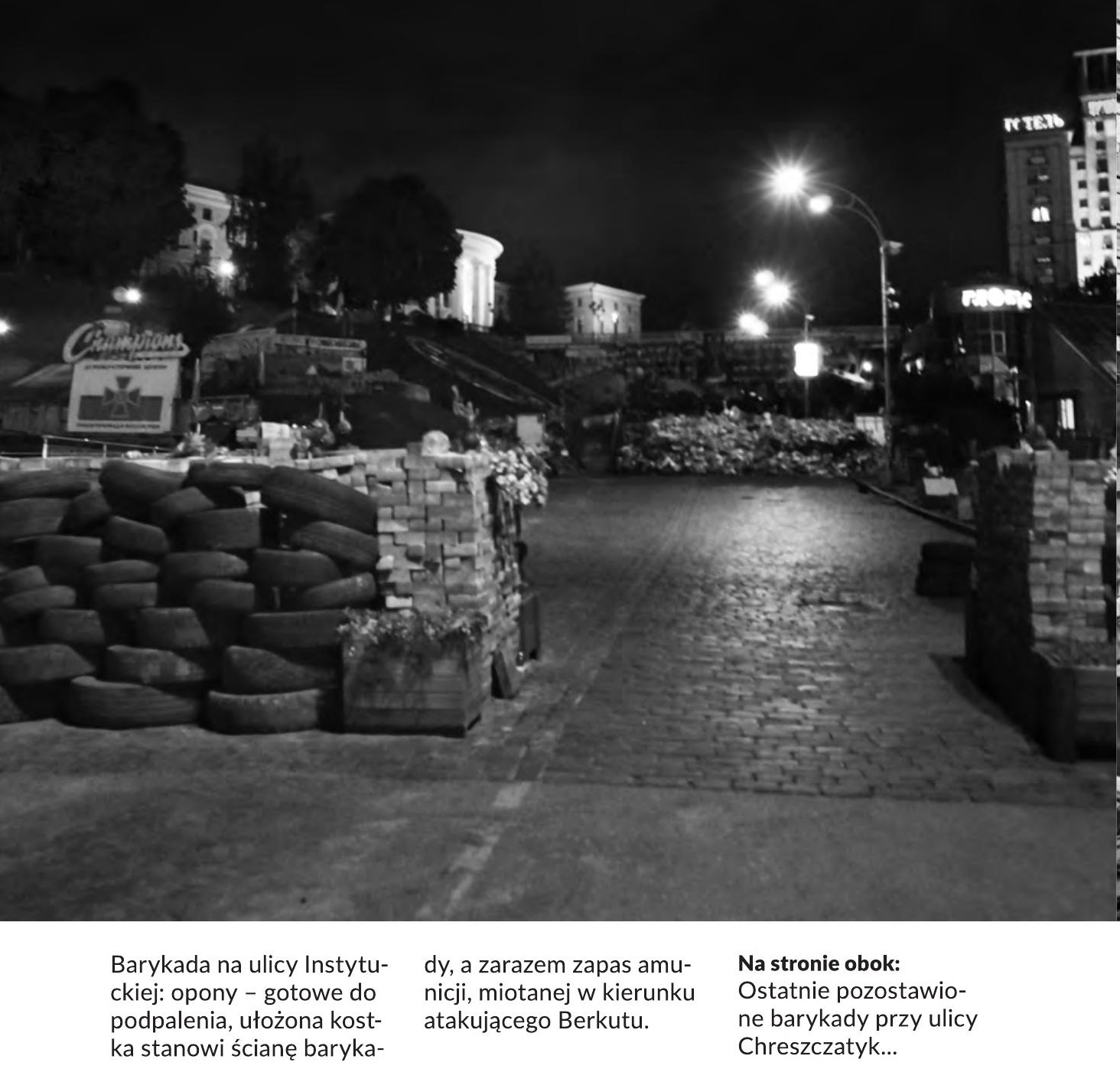




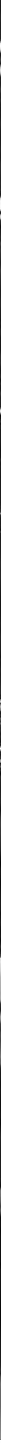




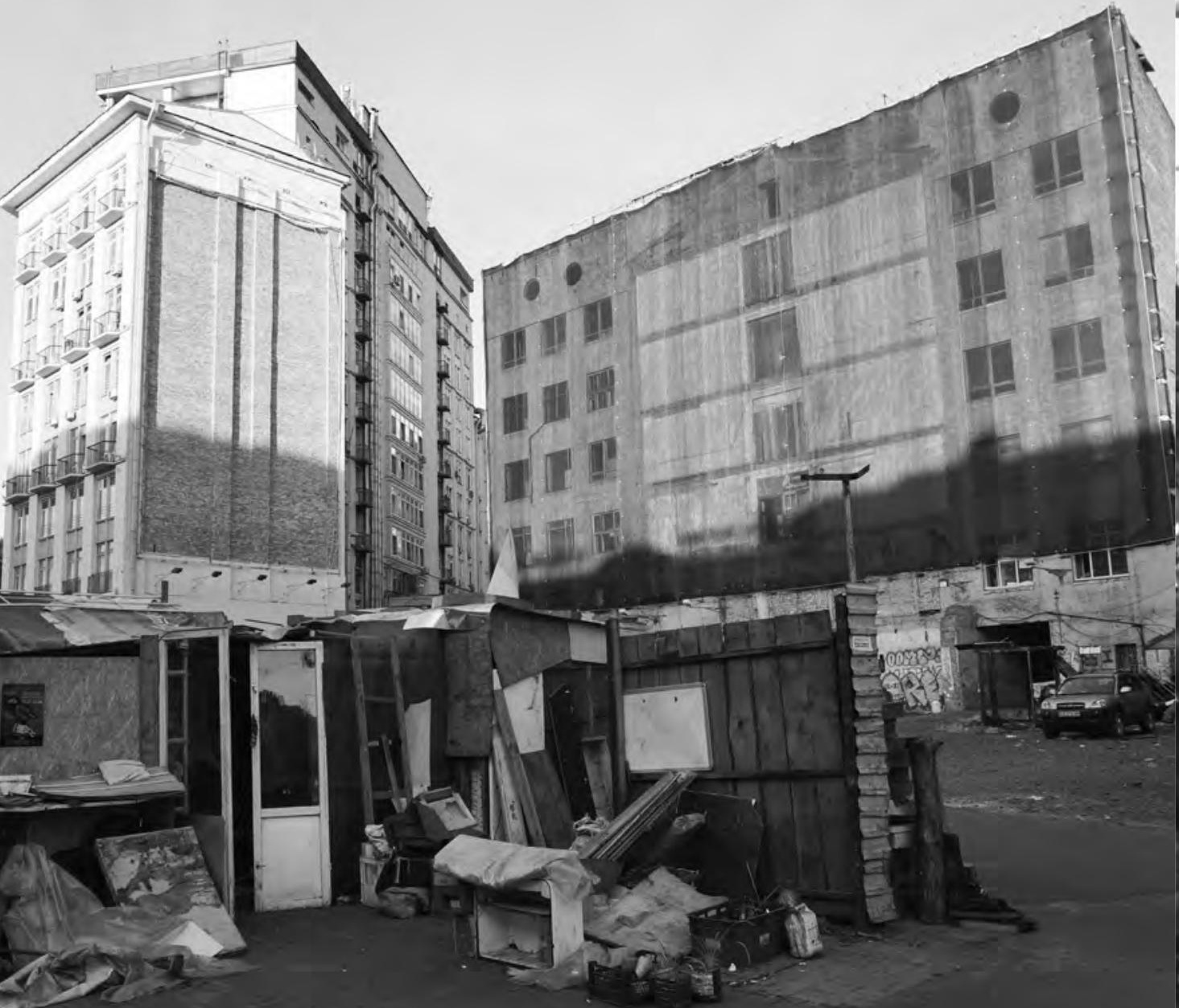

...i prowizoryczne schronienia ich załóg.
Na stronie obok:

Zwiedzanie barykad na

Chreszczatyku przez kijowian - spacer po

muzeum tragicznej

współczesnej historii Ukrainy. 


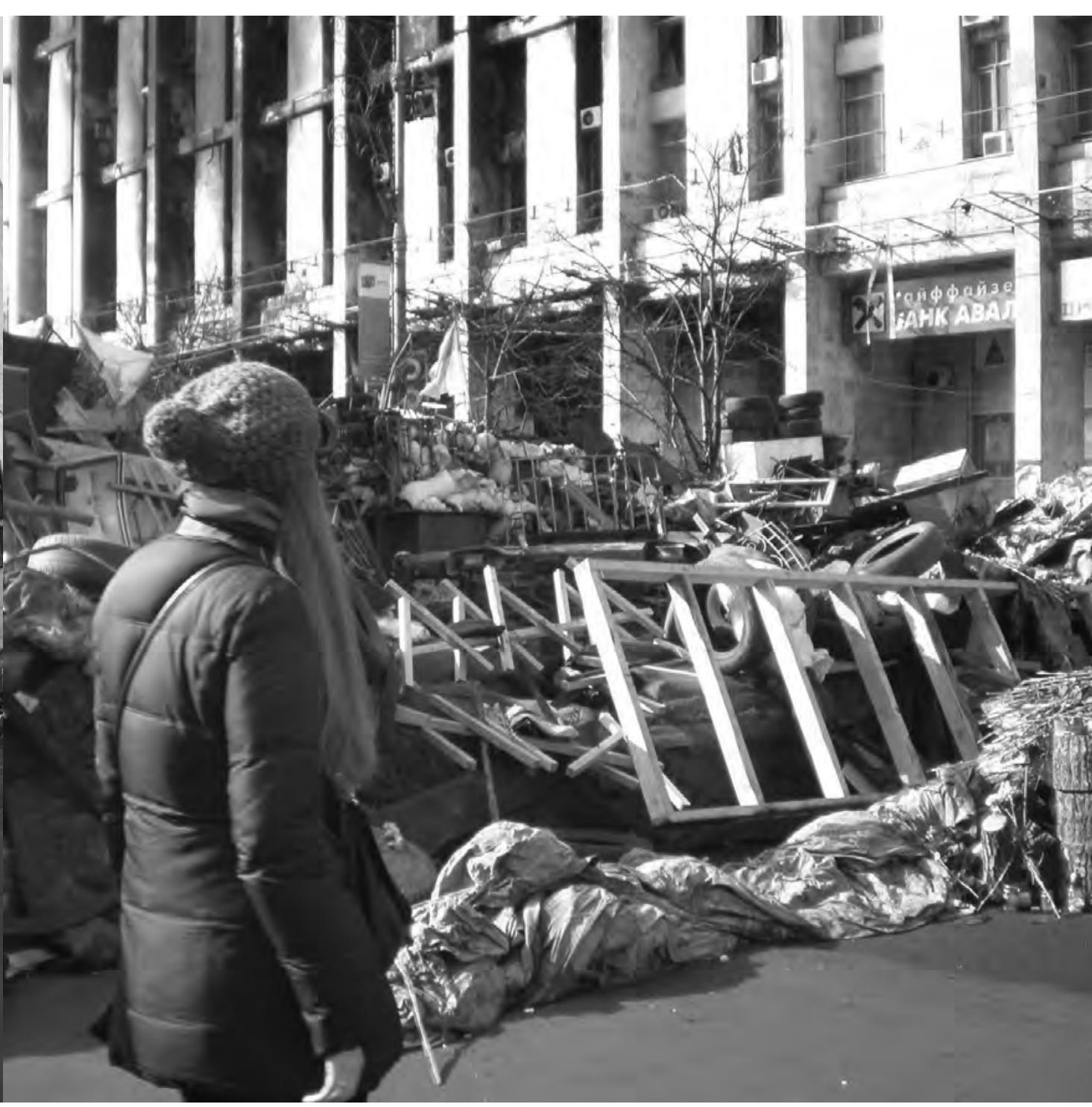




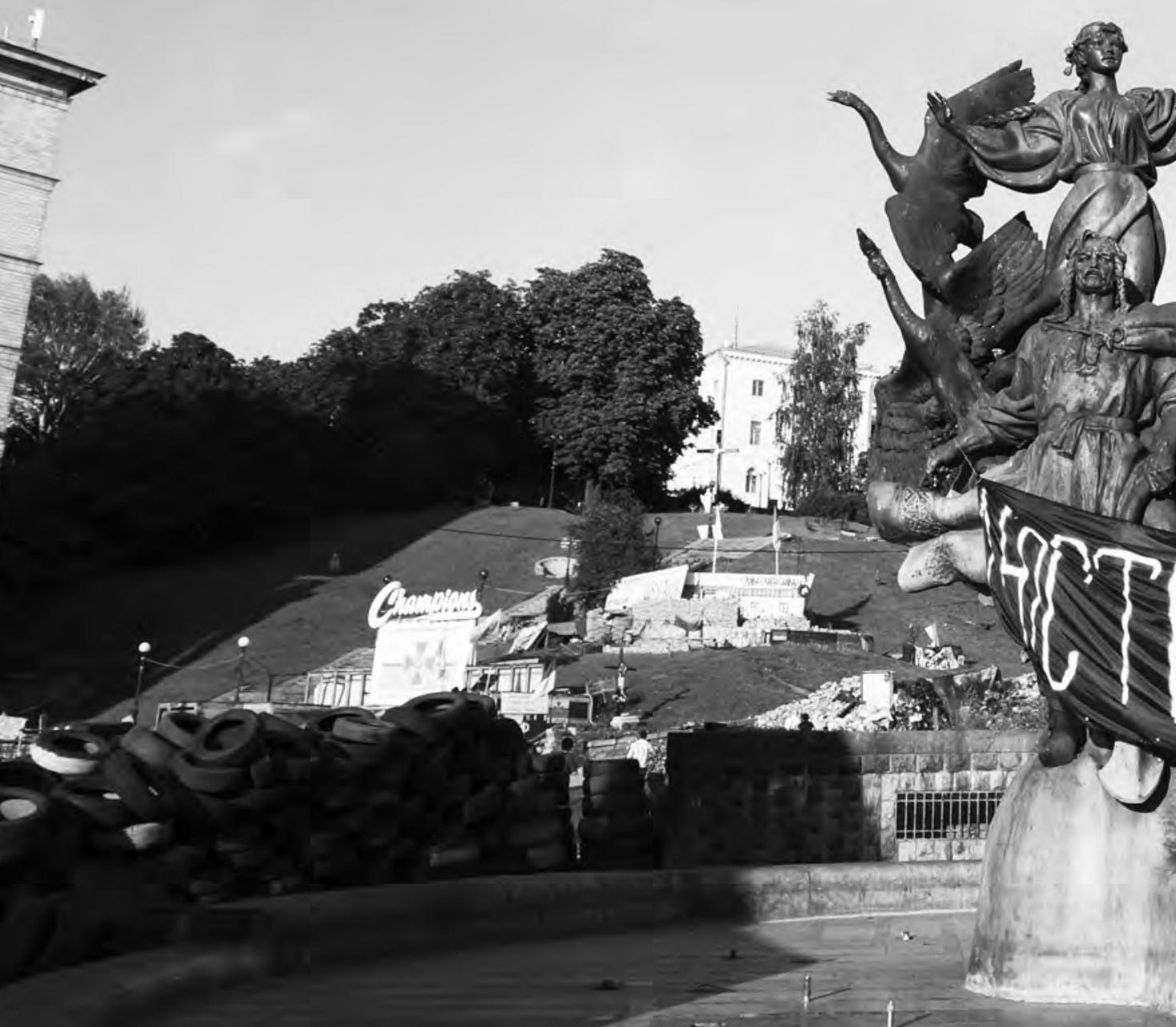

Pomnik Założycieli Kijowa i ich siostry Łybedź. Wona Placu Niepodległości - kół stosy opon i resztki słowiańskich wodzów barykad. Kija, Szczeka, Chorywa 


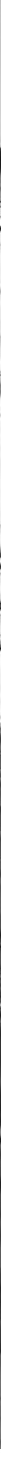




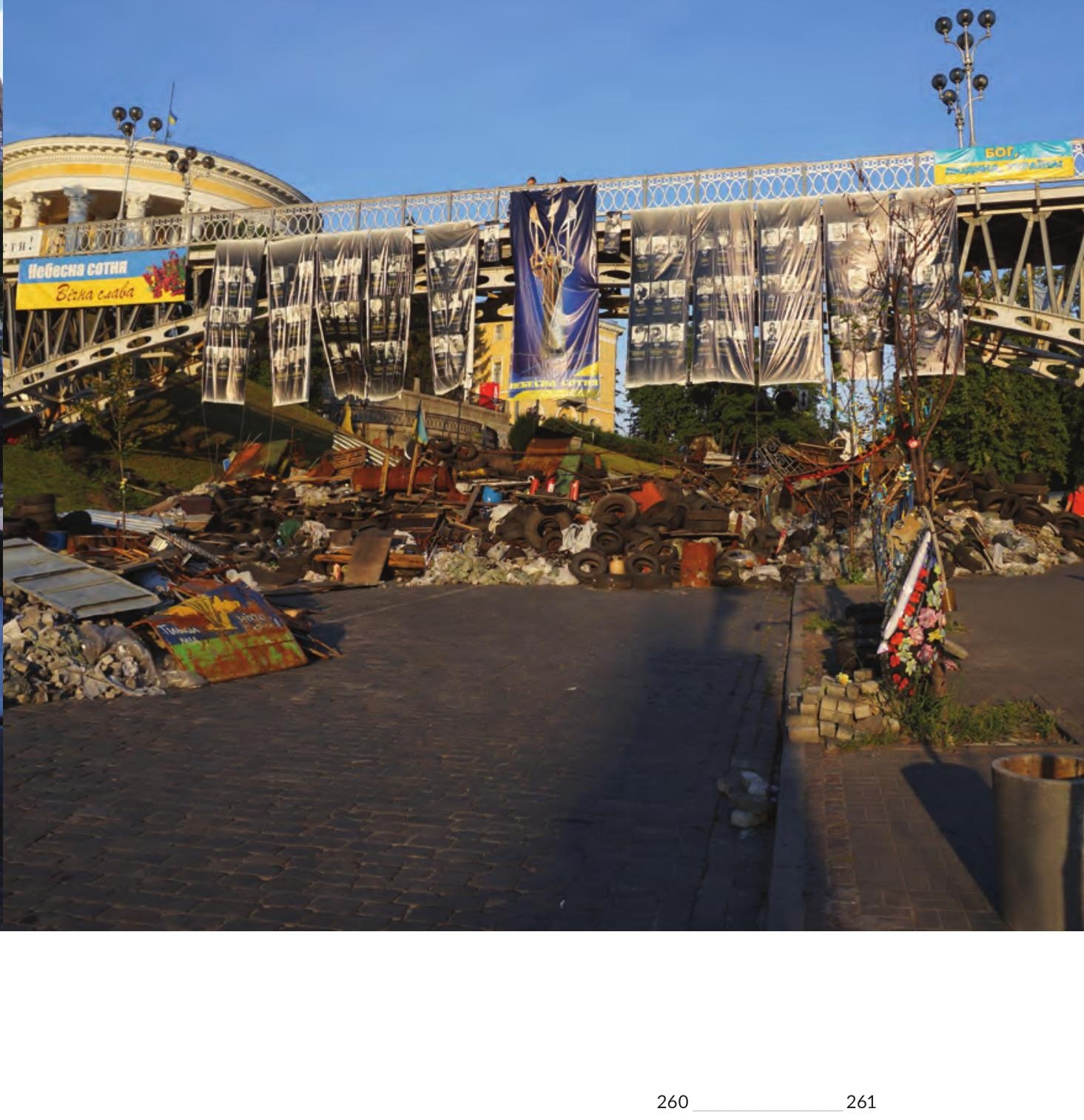




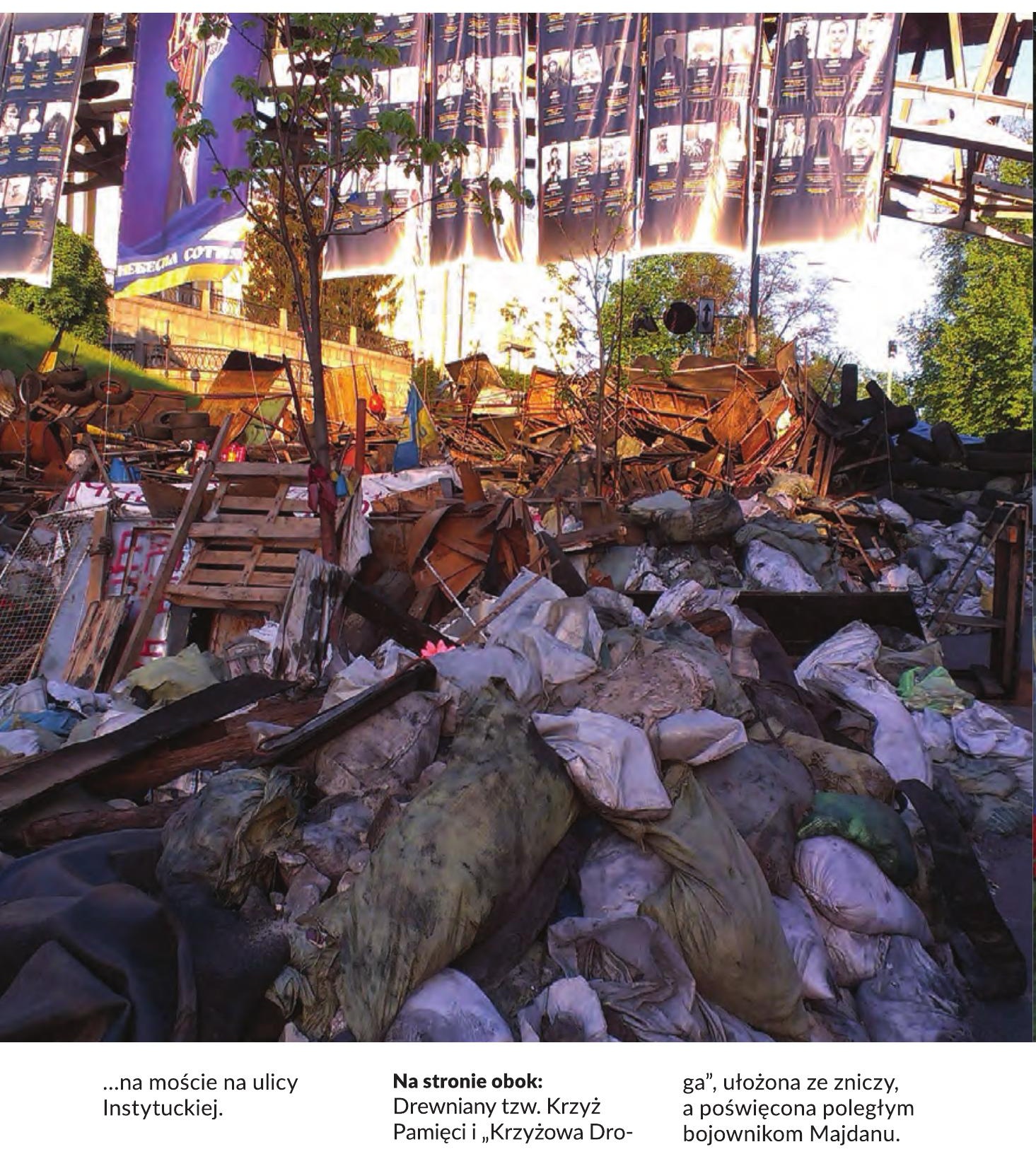




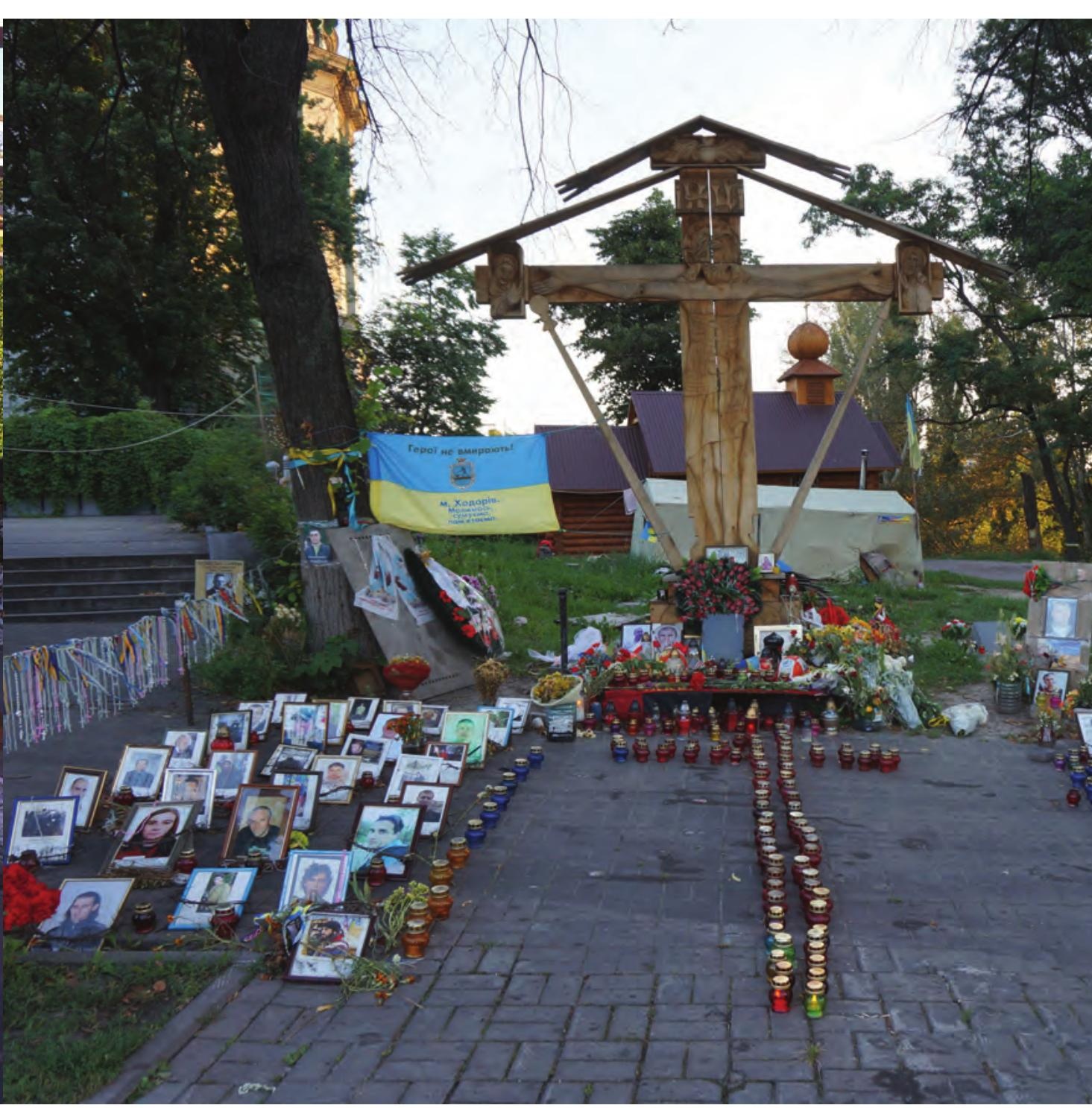




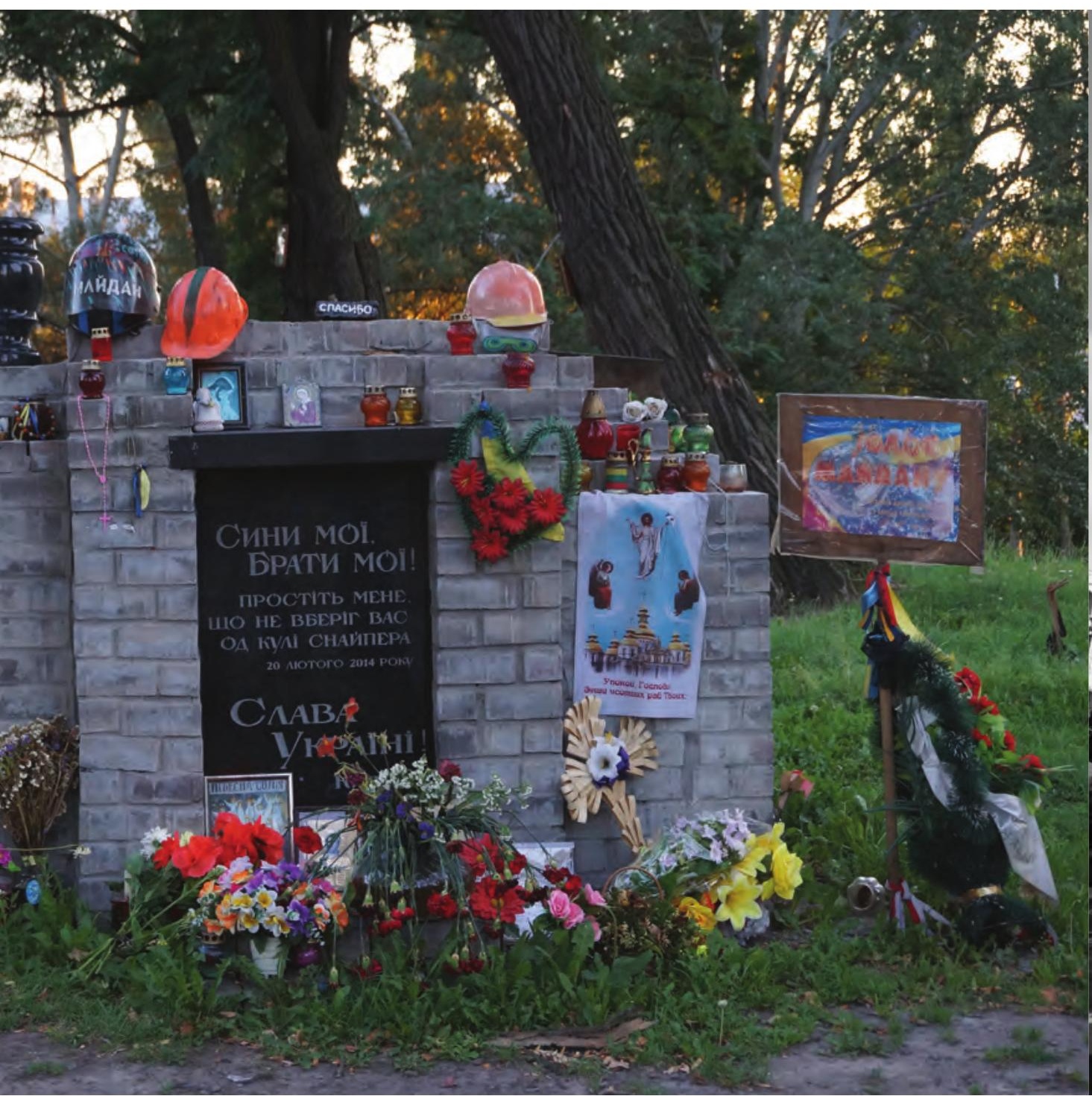

Pomnik poświęcony zabitym przez snajperów przy ulicy Instytuckiej, ozdobiony kwiatami i zniczami oraz kaskami ochronnymi, używanymi przez „majdanowców" jako hełmy.
Na stronie obok:

Tak zwane Tablice Pamięci na cześć poległych Majdanowców na Placu Niepodległości. 


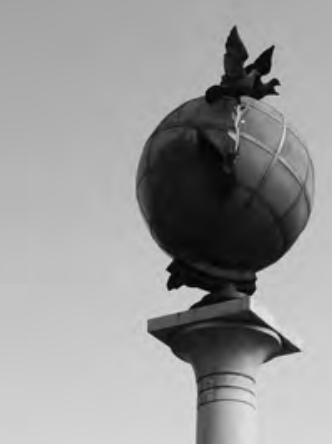

TICKETSU:

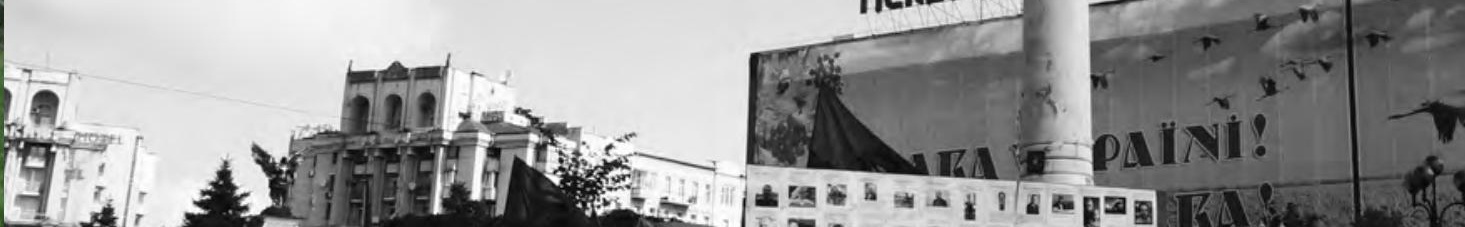
g.t.

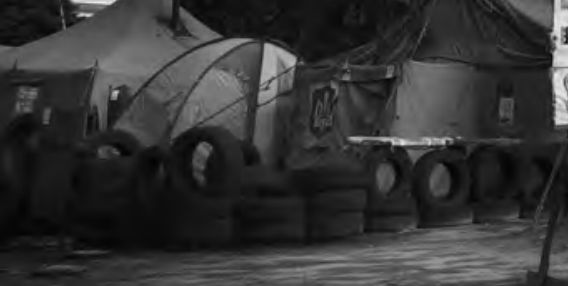

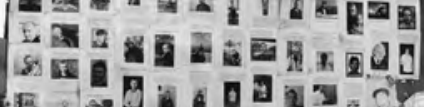

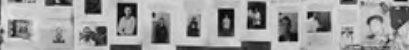
(2) 다. and. What: 


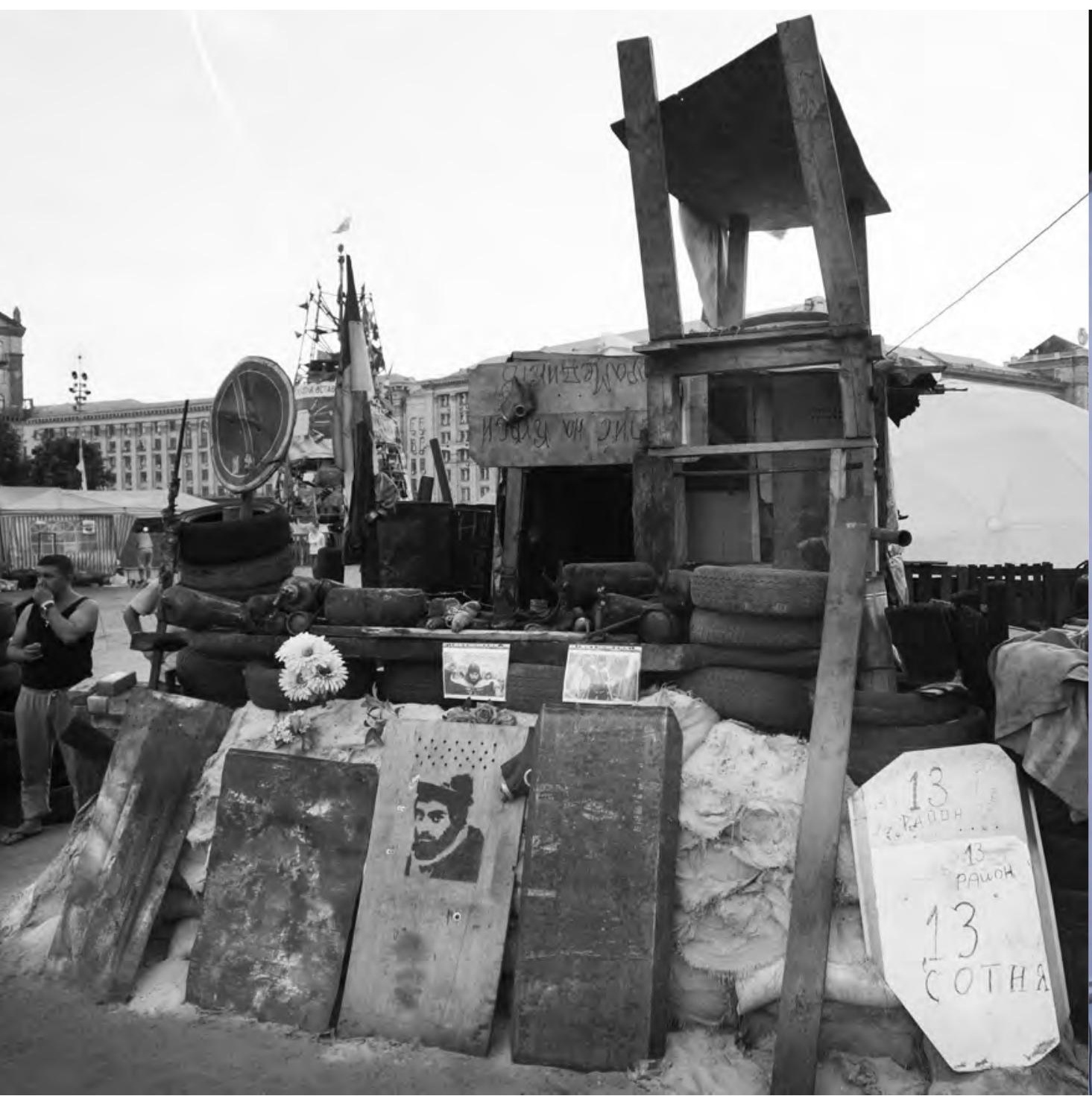

Miejsce śmierci pierwszego „majdanowca”, Ormianina Siergieja Nigojana.
Na stronie obok: Improwizowane "Muzeum Broni" - sprzętu bojo- wego, używanego przez

Berkut przeciwko bojownikom Majdanu. 


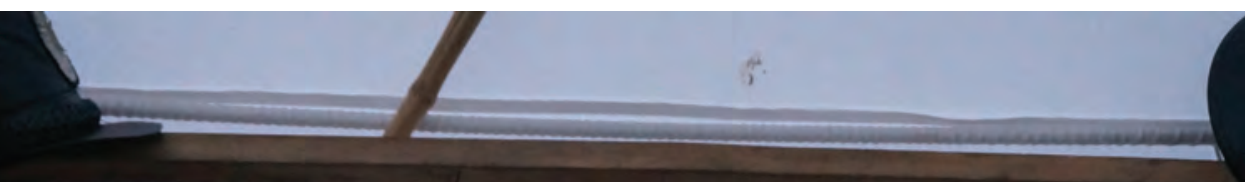
Фак "Мирна" "броя БЕРКУТУ

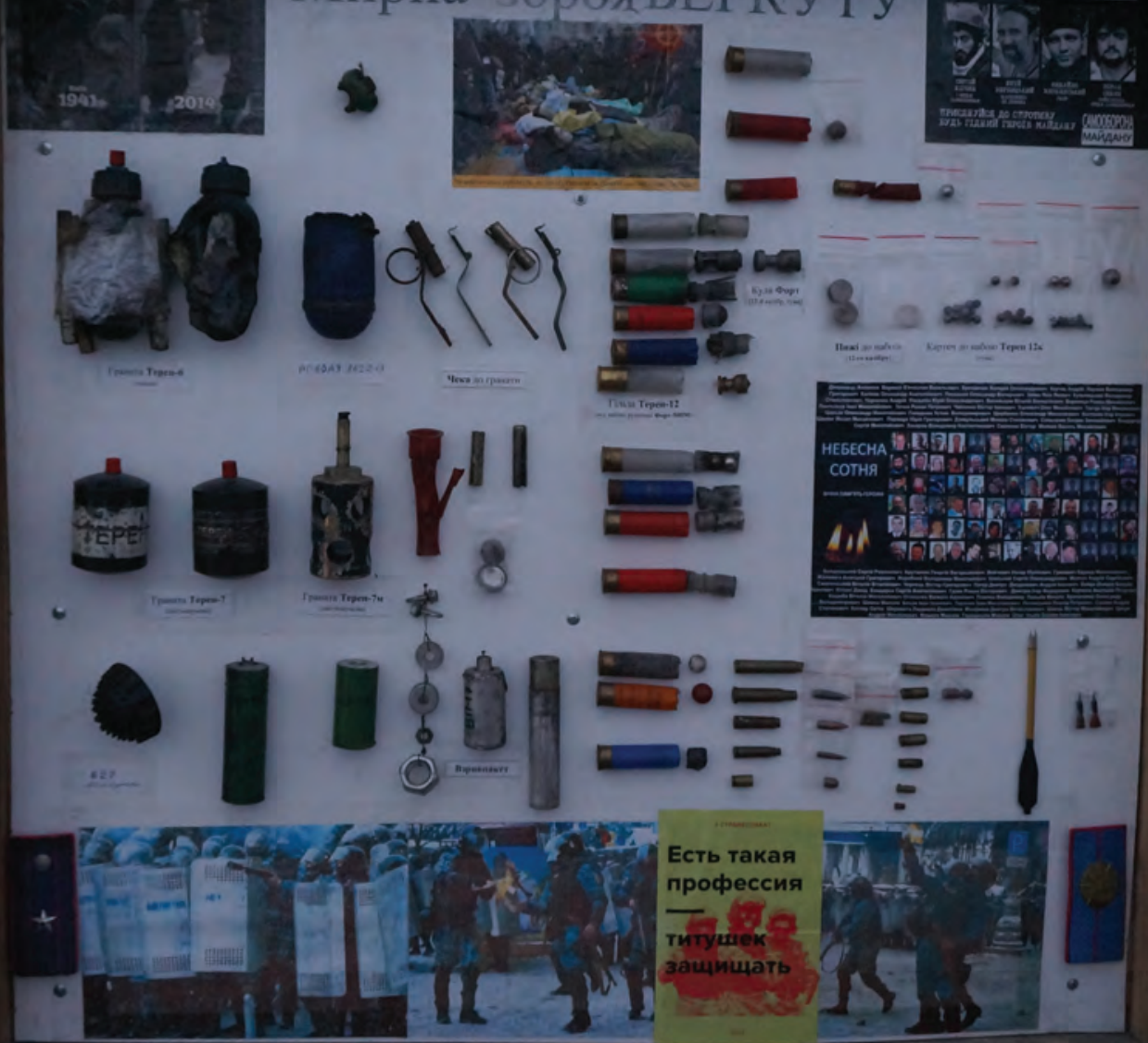




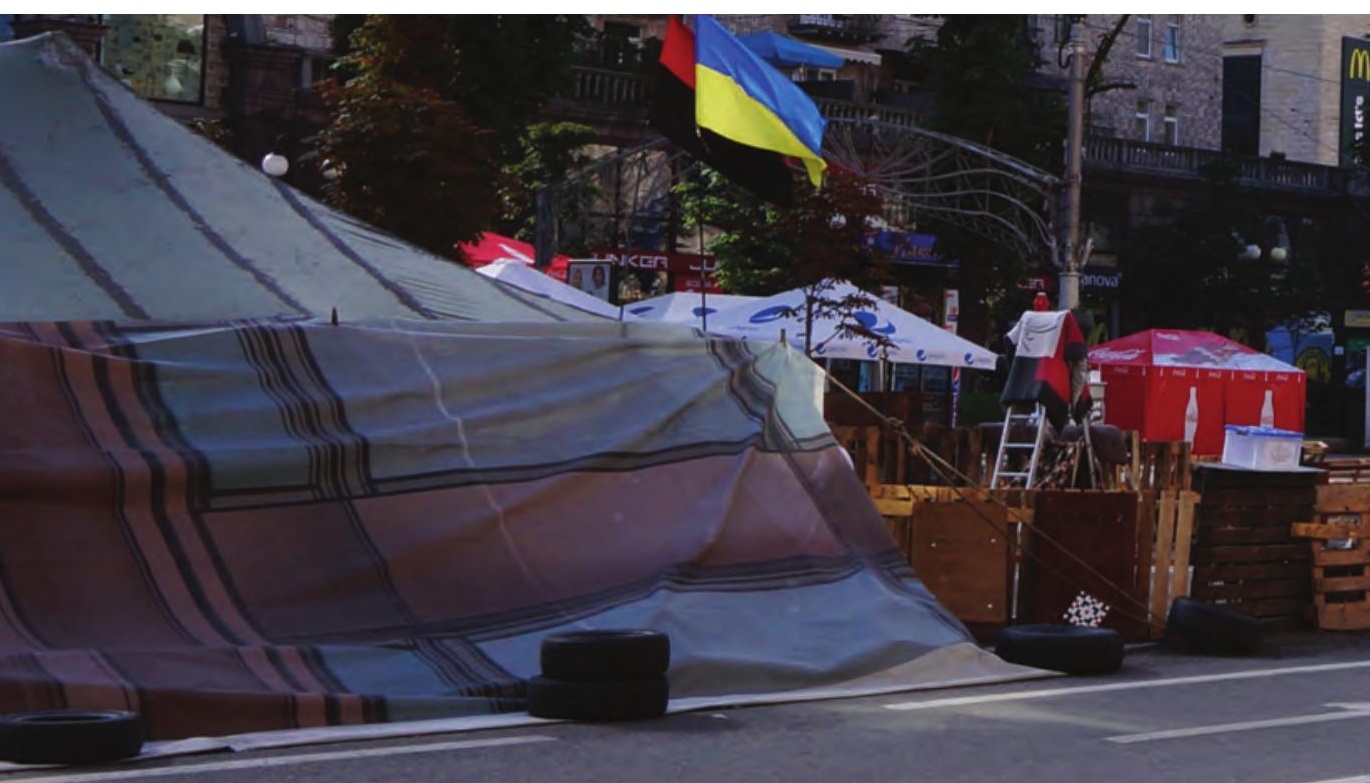

Widok na ulice Chreszczatyk.
Na stronie obok:

Na pierwszym planie jeden z symboli Euromajdanu - stynne pianino, na którym grywali "majdanowcy" i artyści odwiedzający protestujących. 


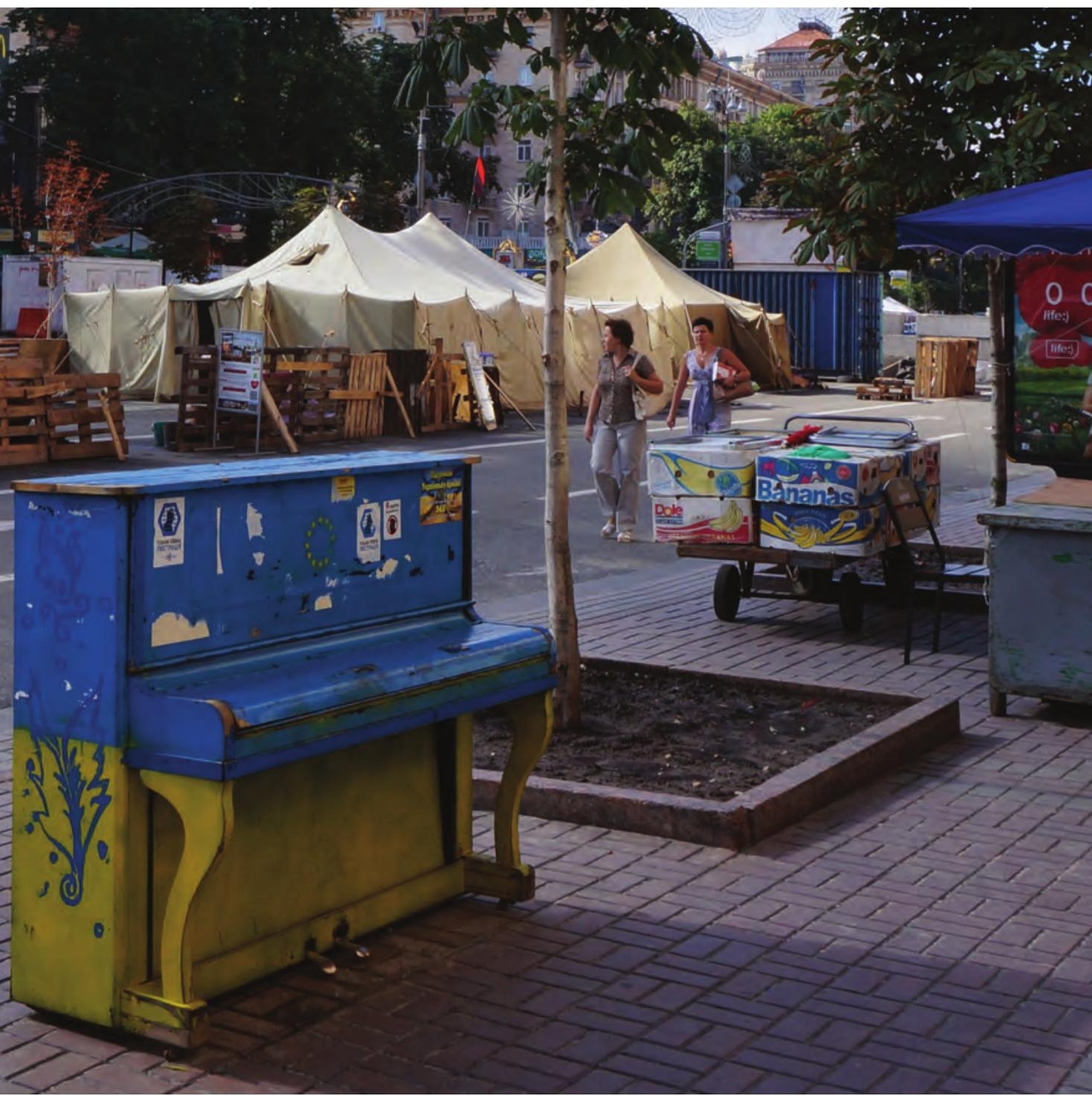




\section{PRZESZŁOŚĆ I PRZYSZŁOŚĆ}

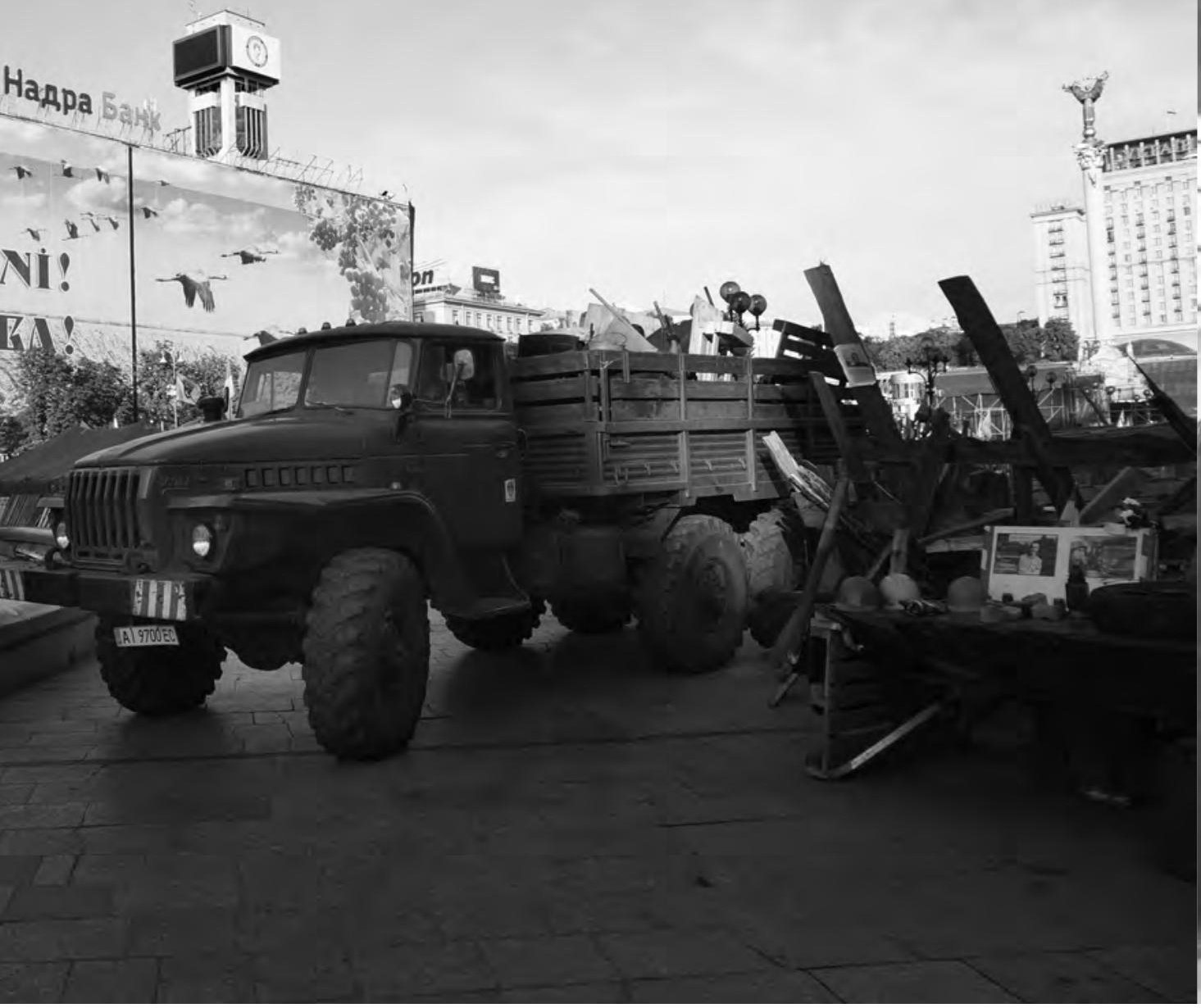

Ciężarówka wywożąca resztki obozowiska Majdanowców z Placu Niepodległości latem 2014 roku.
Na stronie obok:

Namiot ze stanowiskami komputerowymi - tzw. Internet-Forum - na
Placu Niepodległości.

Nowoczesność... 


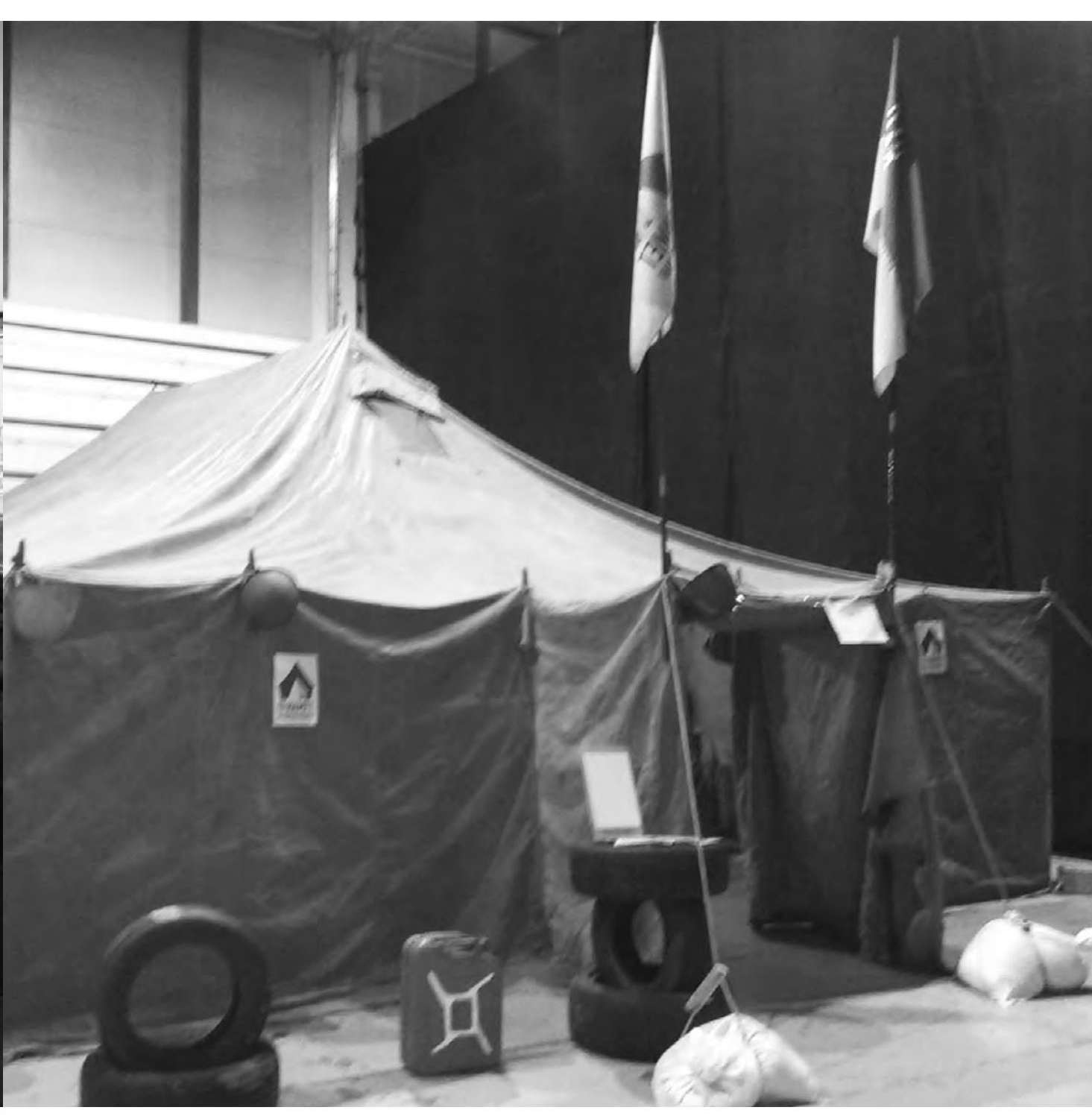




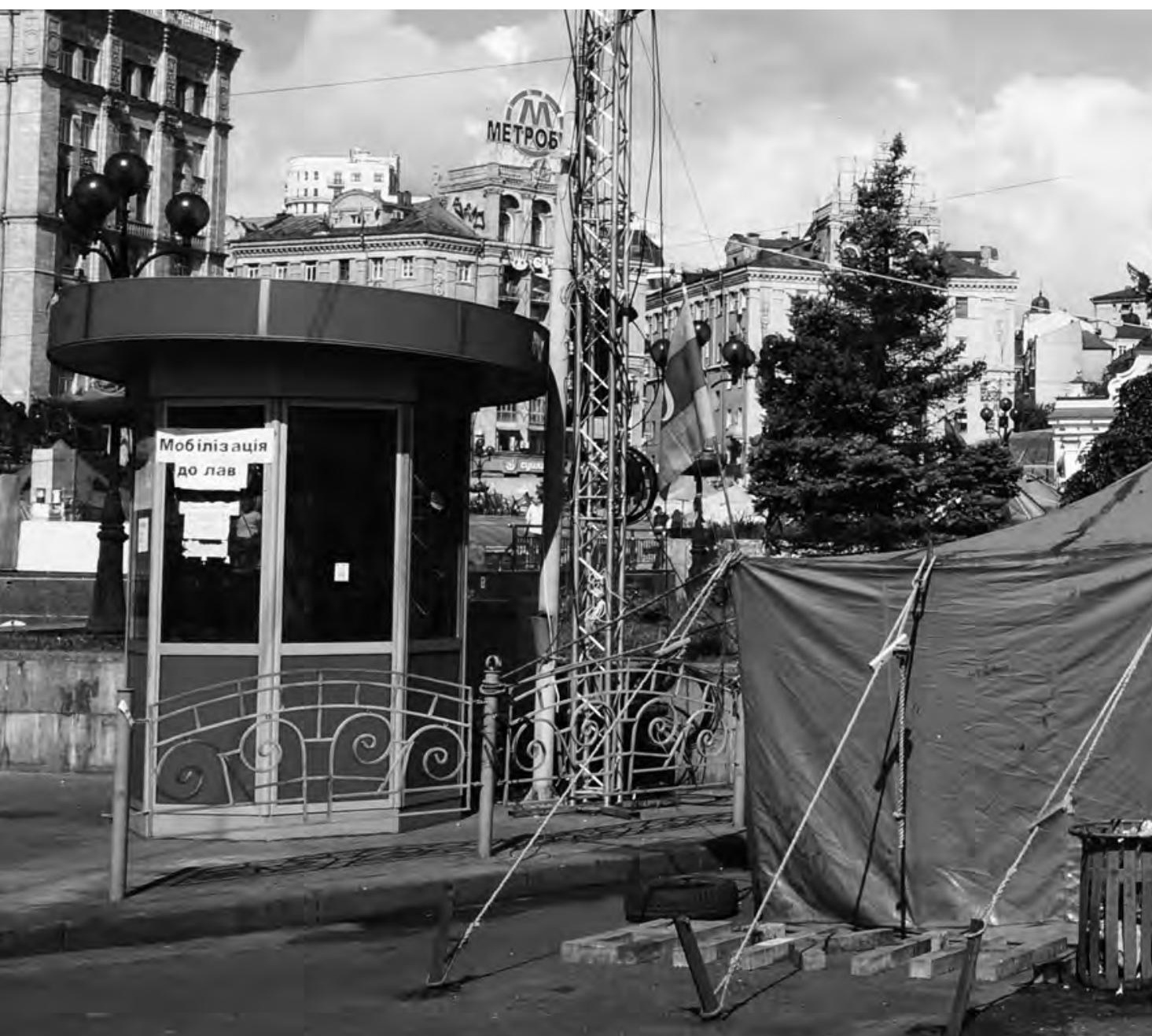

...i złowrogi cień przeszłości - namiot na Placu Niepodległości, w którym dokonywane są zapisy ochotników do walki z rosyjską agresją na wschodzie Ukrainy. 


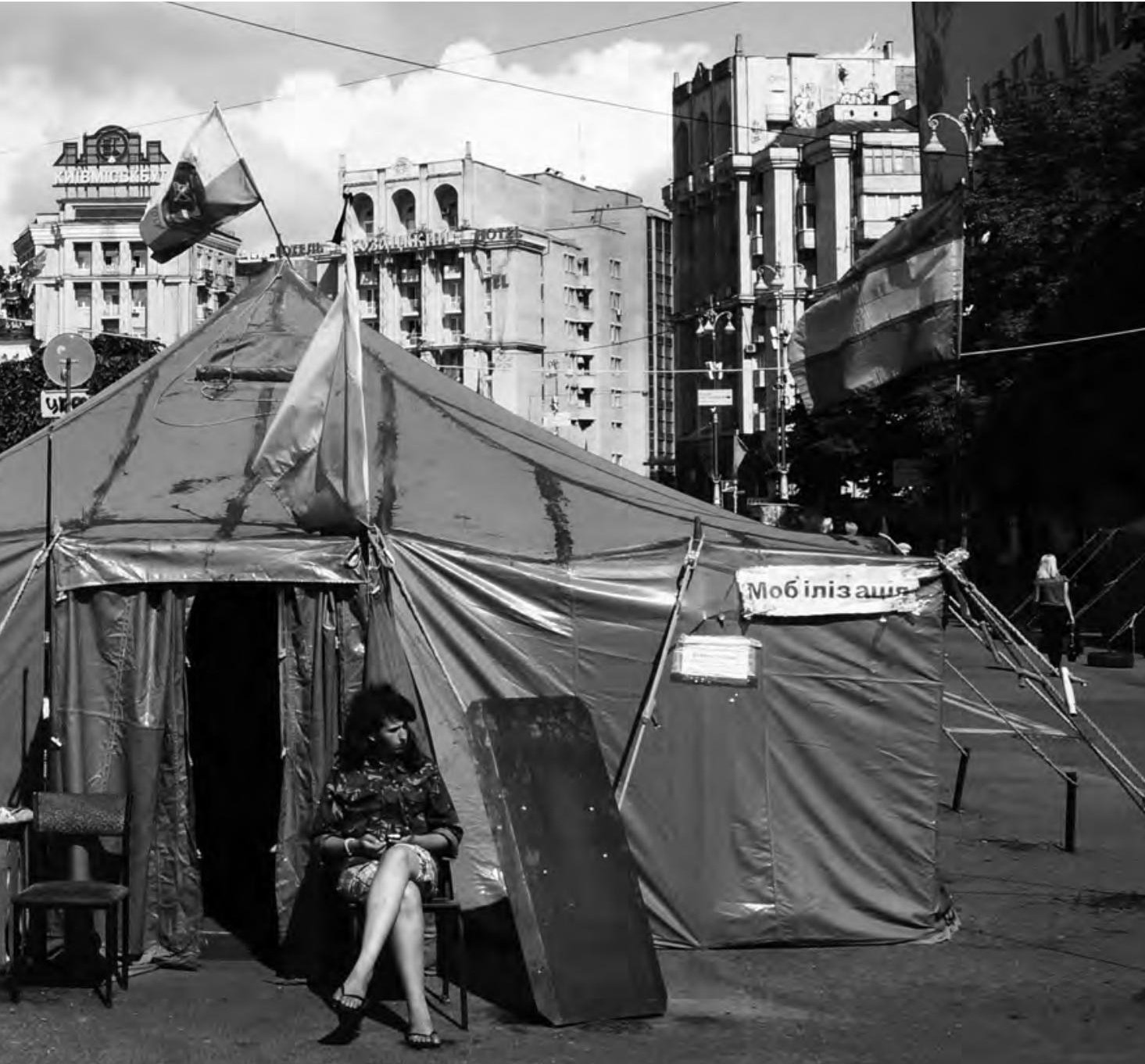




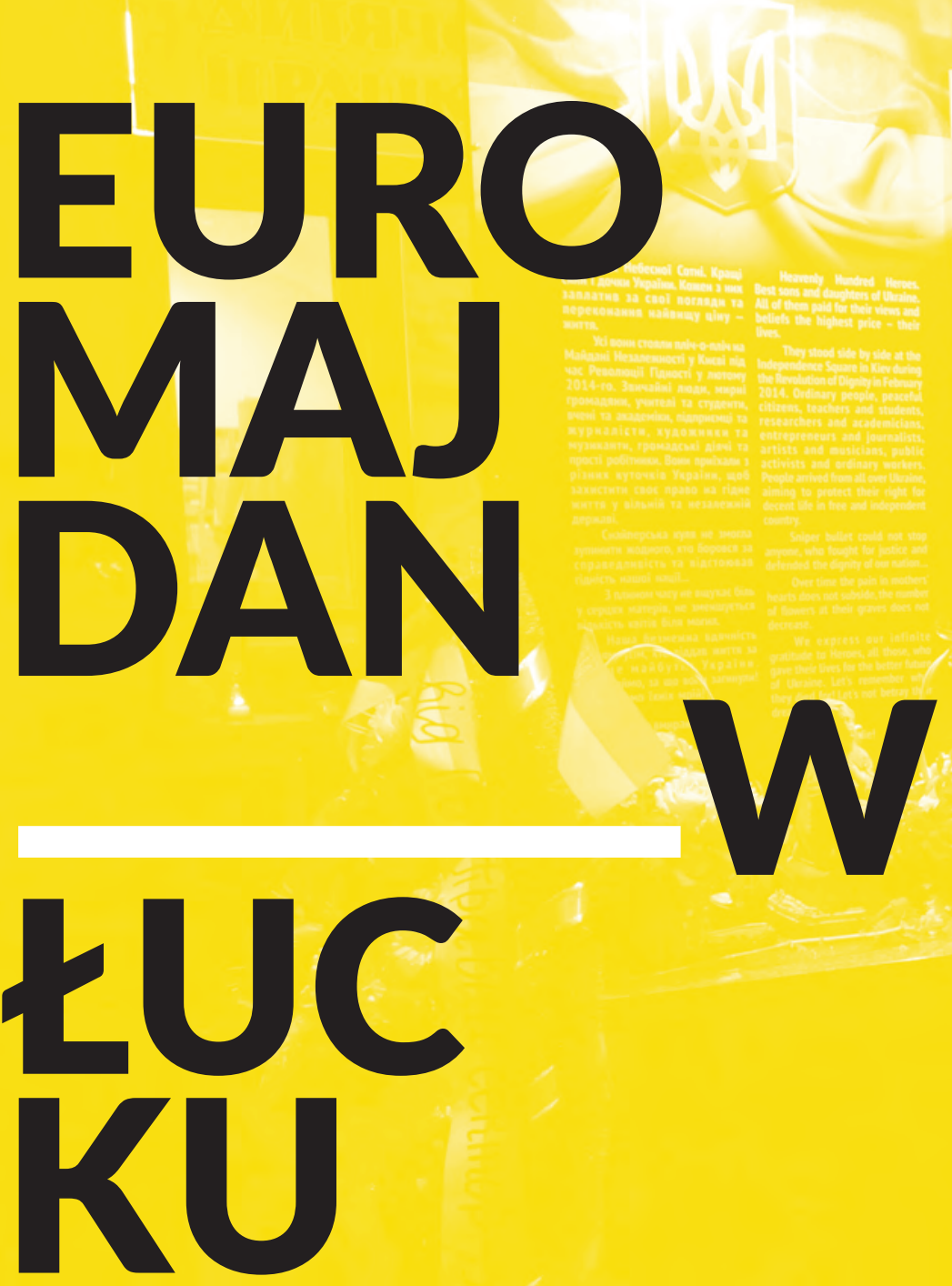




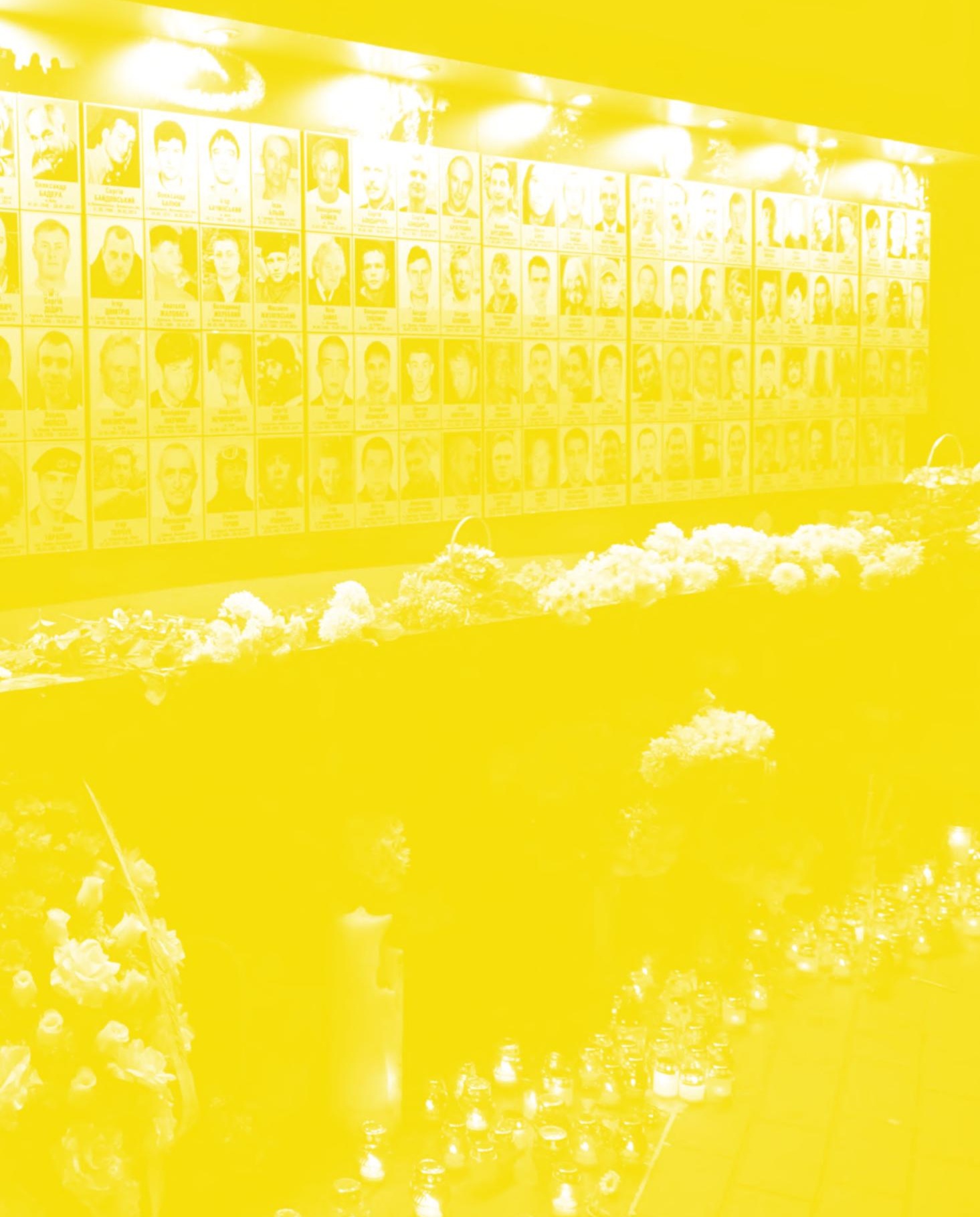




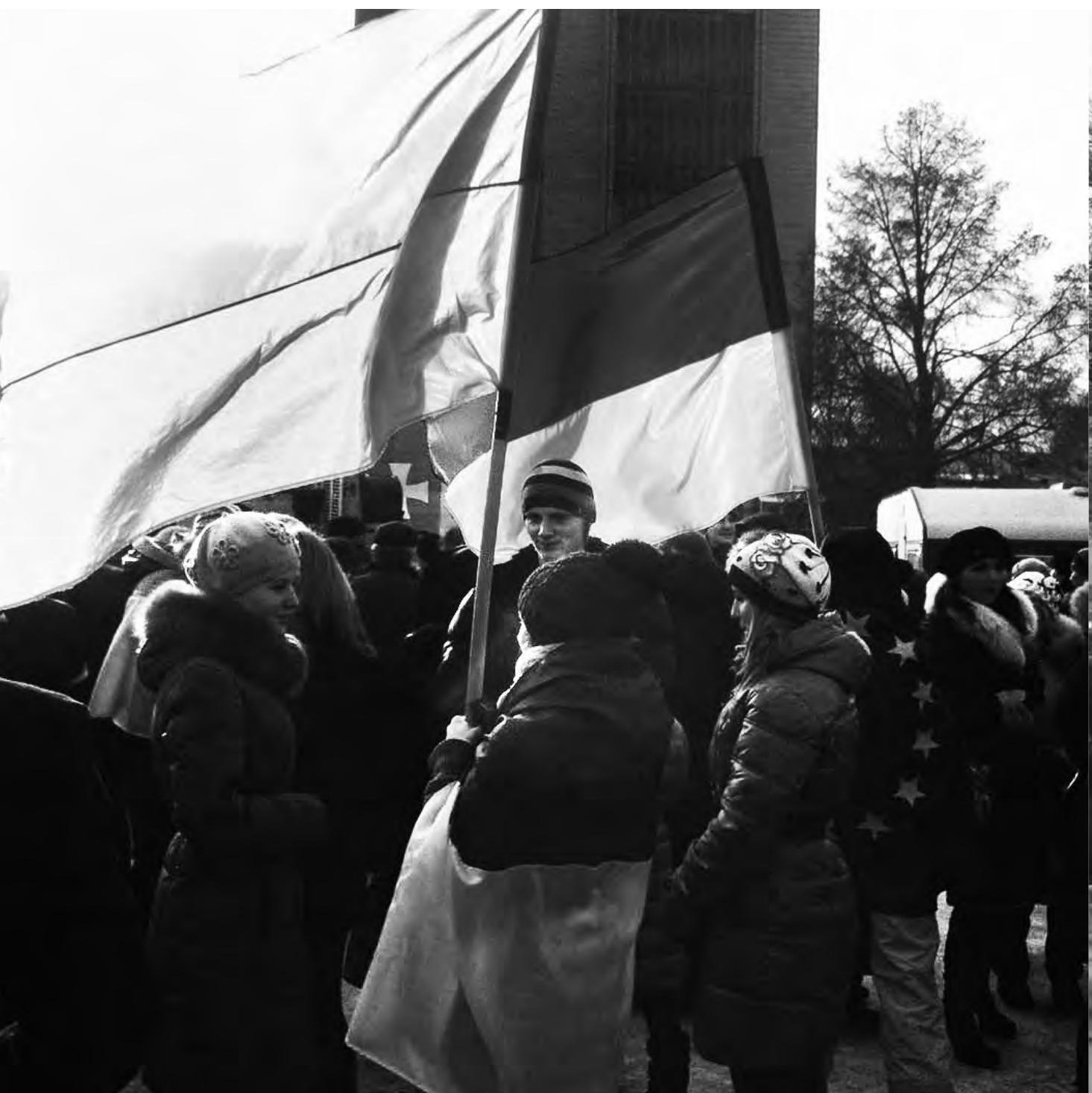

Kijowskiemu Euromajdanowi towarzyszyły solidarnościowe protesty w wołyńskim Łucku.

\section{Na stronie obok:}

Coraz liczniejsze grupy przeciągały łuckimi ulicami... 


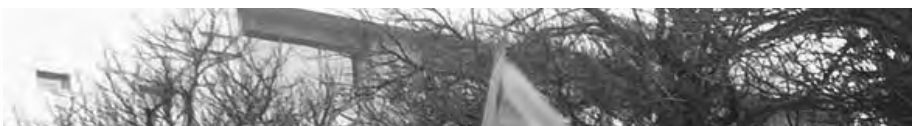

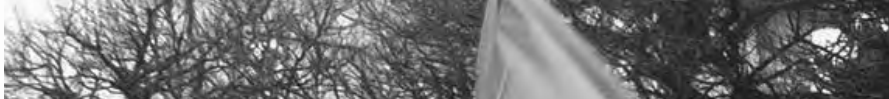

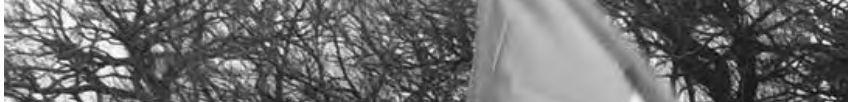

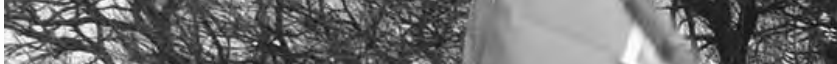

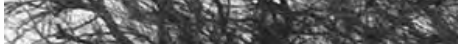

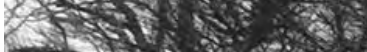

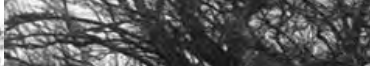
Natis

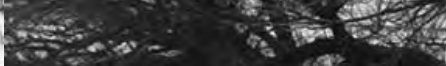

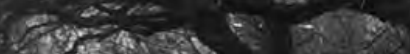

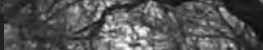

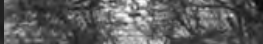

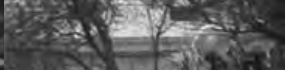

1) $10^{2}=0$

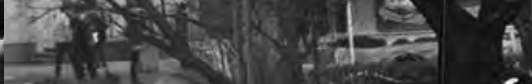
$=73$ 


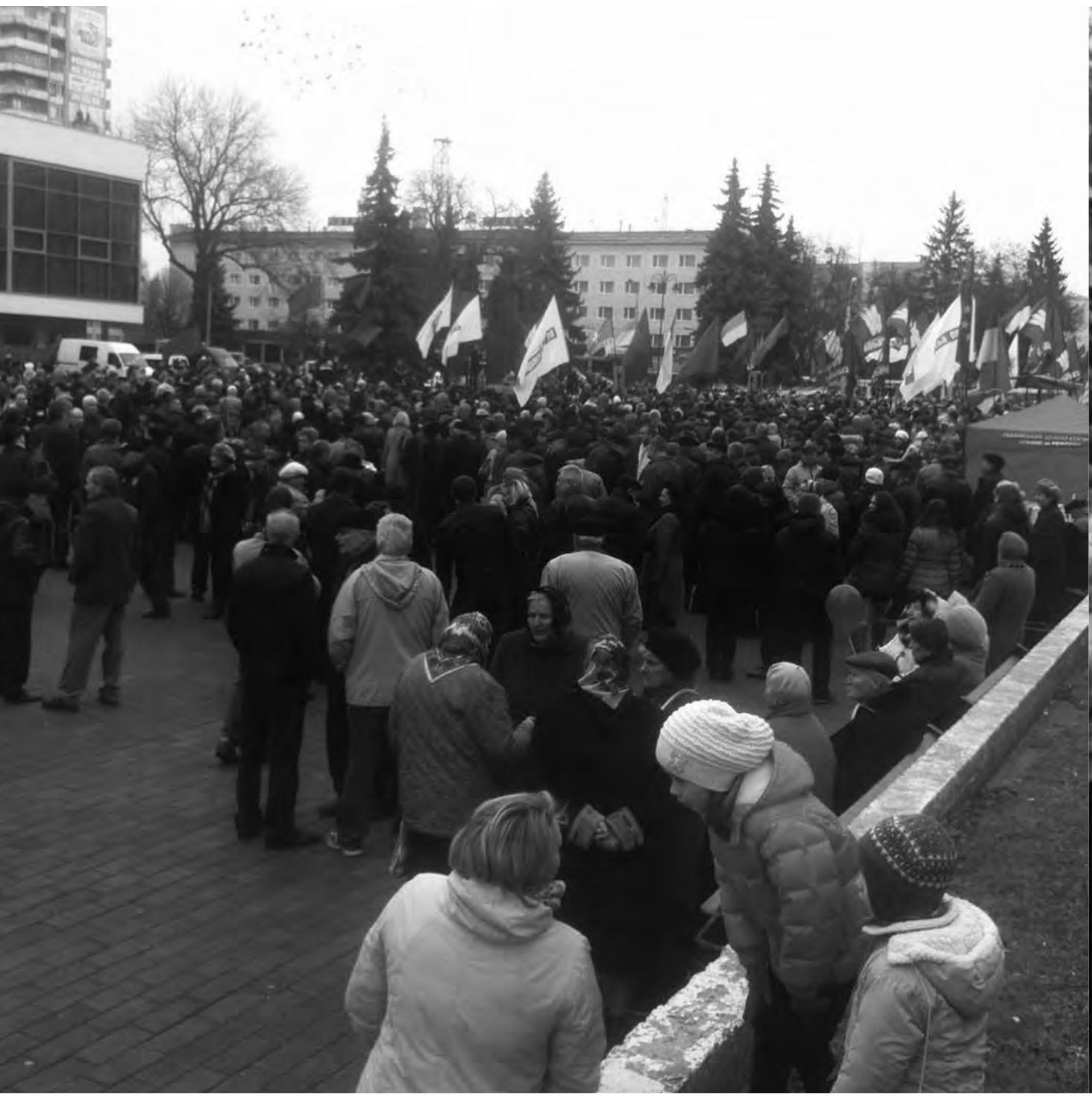

...czując swą siłę...

\section{Na stronie obok:}

...i krzepnąc w oporze. 


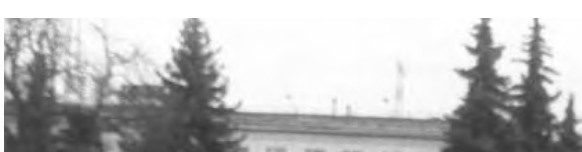

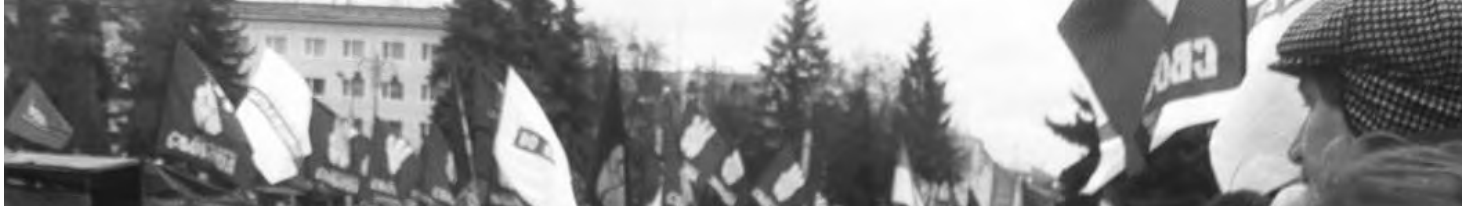

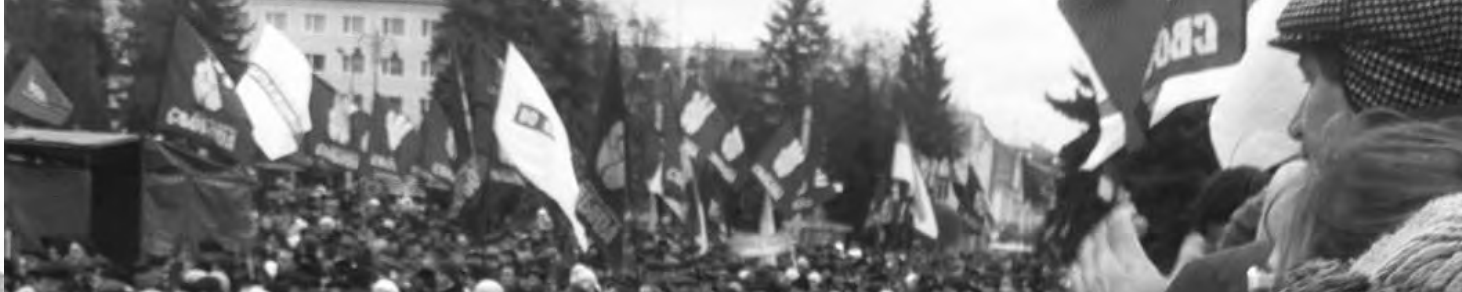

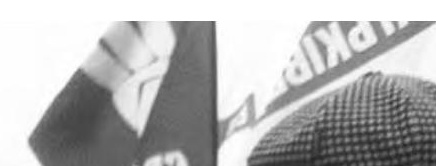

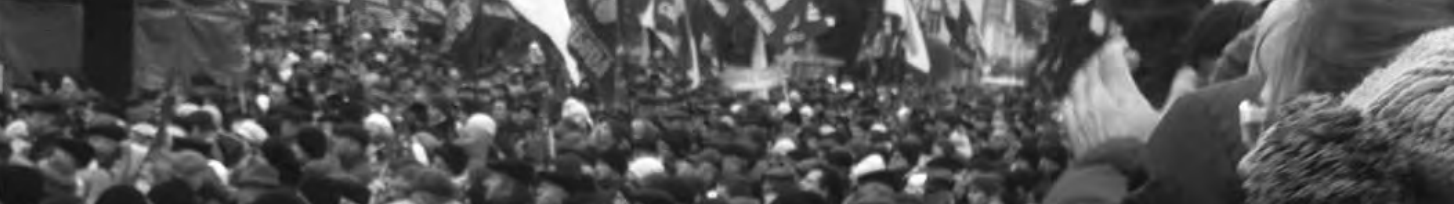

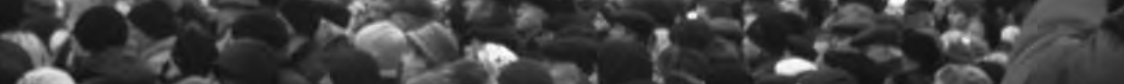

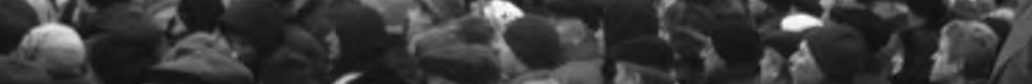

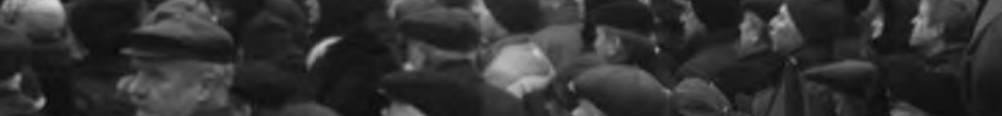

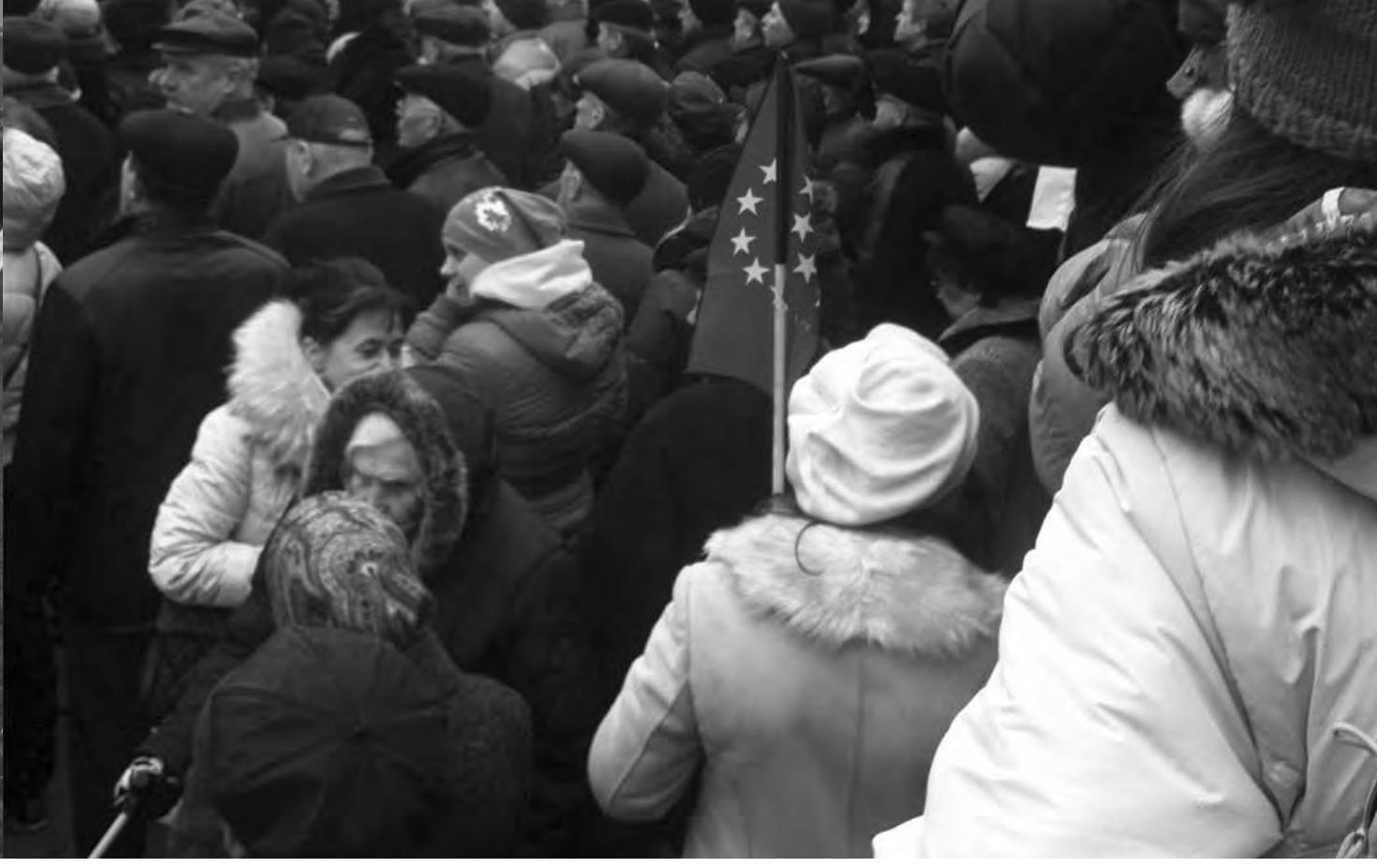




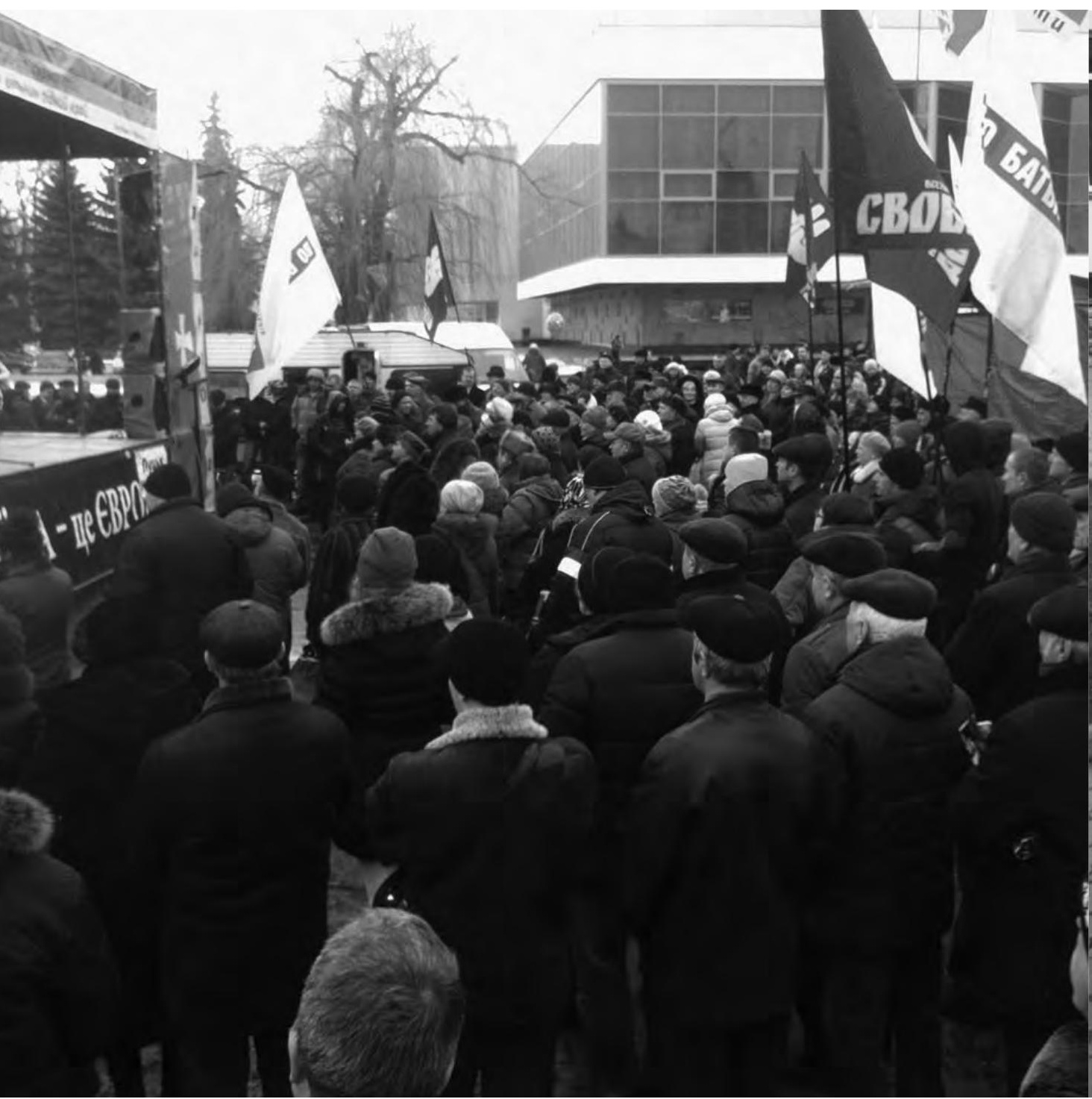

Tłumy skupiały się także pod sceną tuckiego Euromajdanu, skąd płynęły informacje o rozwoju sytuacji w Kijowie i na całej
Ukrainie oraz komunikaty dotyczące działań podejmowanych przez przeciwników reżimu Janukowycza na Wołyniu.
Na stronie obok:

W tłumie pojawiły się transparenty piętnujące prezydenta i jego współpracowników jako 


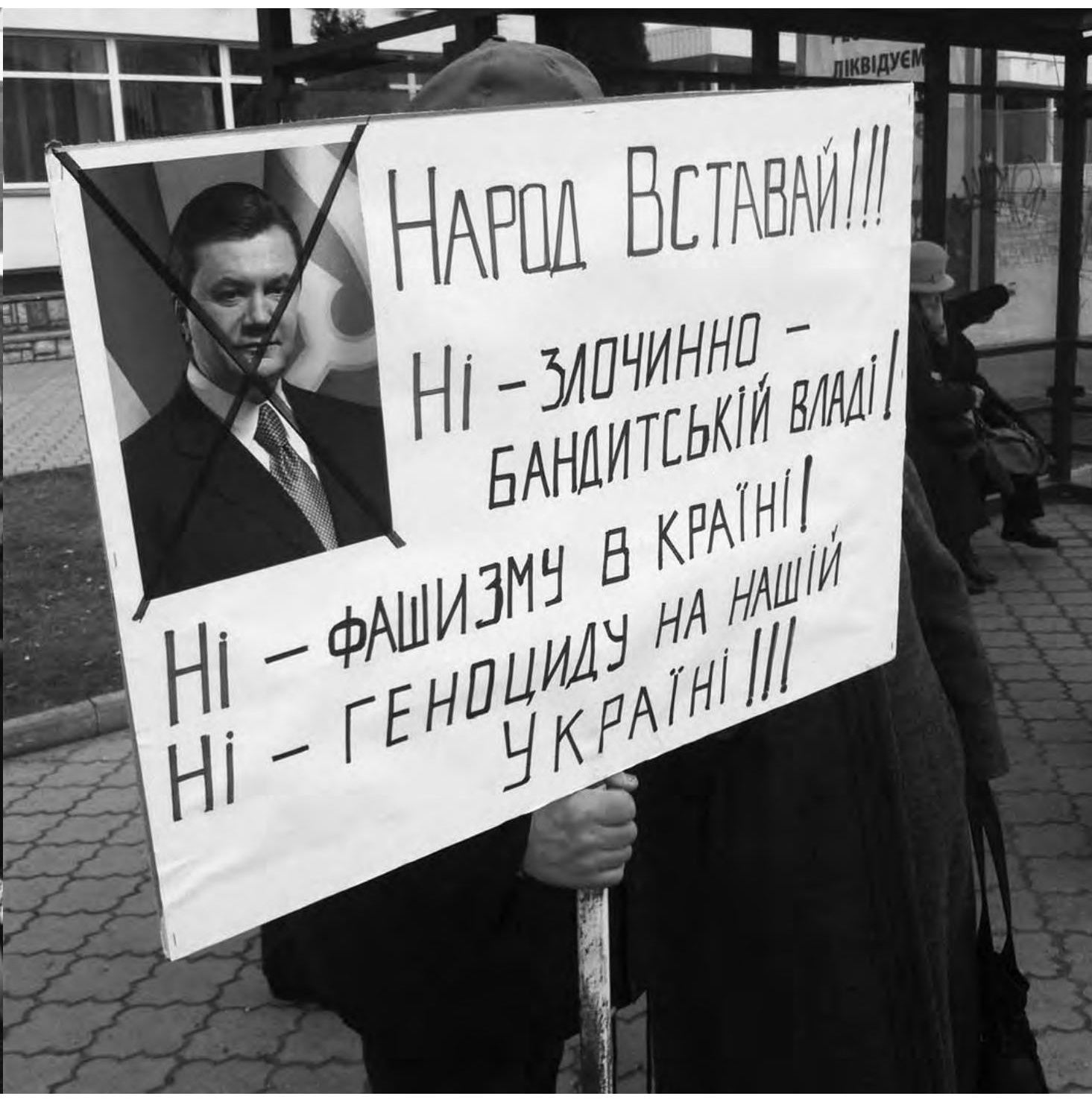

"bandytów”, „ludobójców" i "faszystów". 


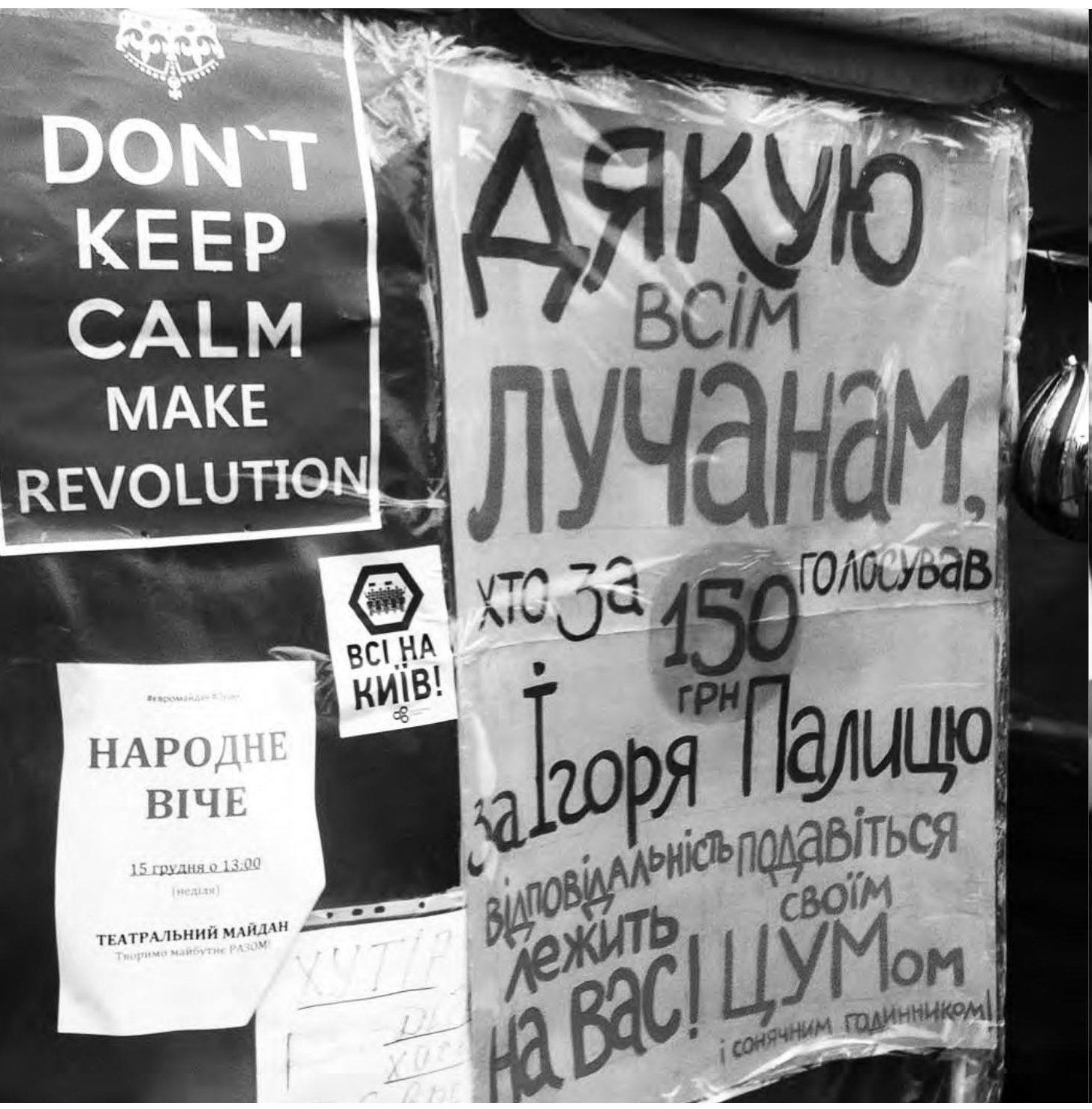

Niektóre hasła wskazywały - niekiedy z dowcipnym dystansem - metodę walki...

\section{Na stronie obok:}

...i mobilizowały niezde-

cydowanych do przyłączenia się do protestu. 


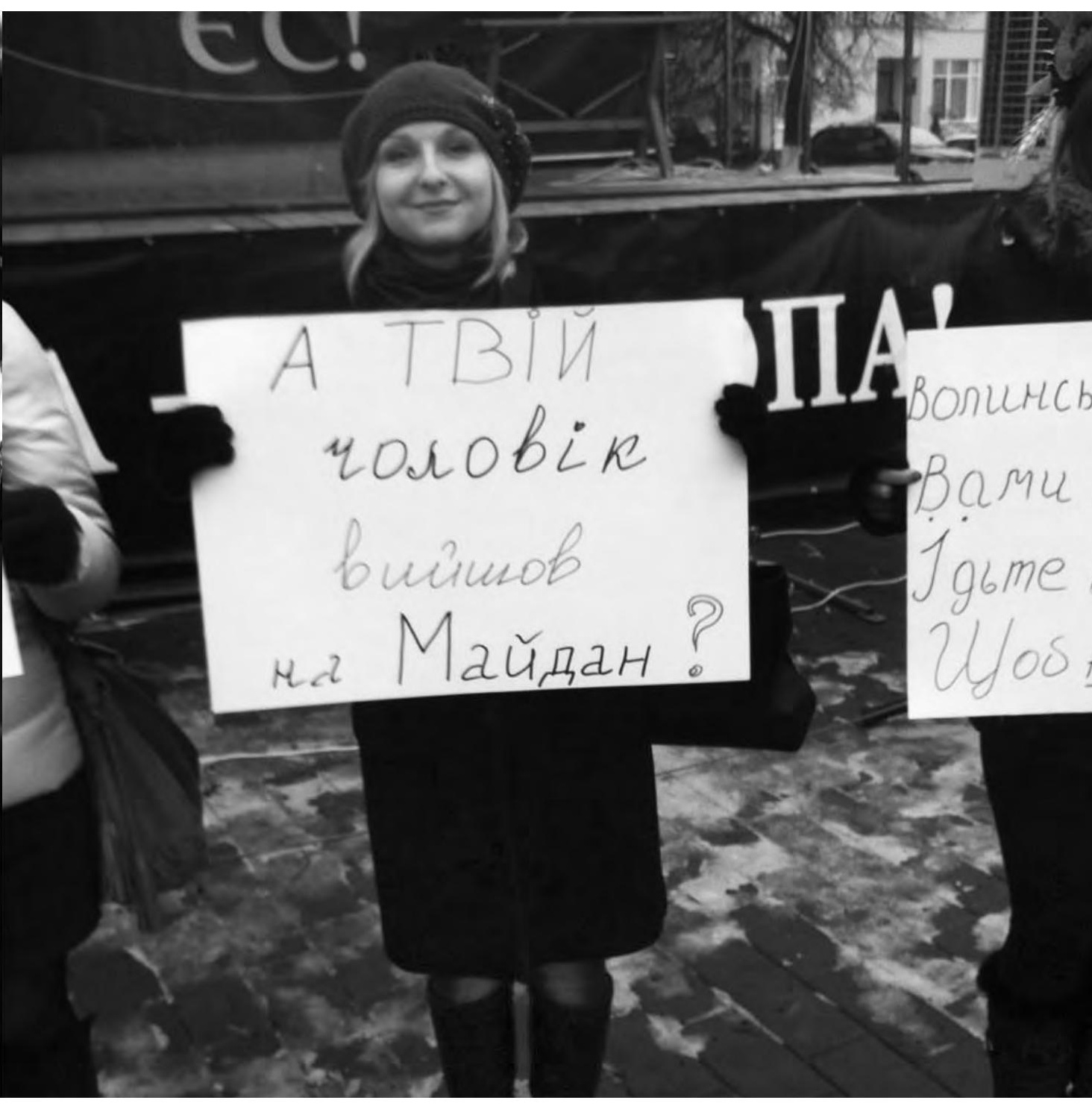




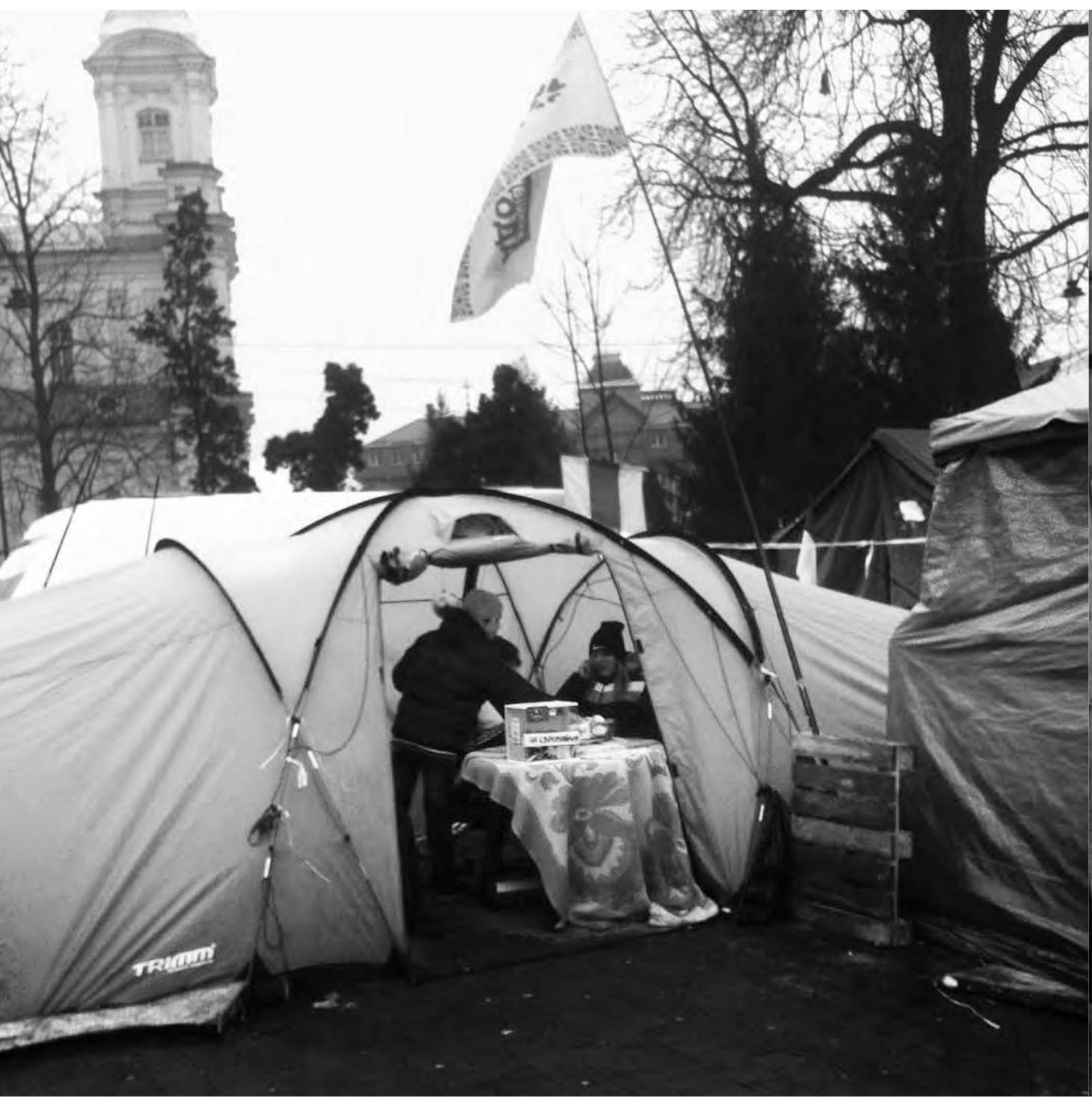

Z czasem Na Euromajdanie w Łucku wyrosło prawdziwe namiotowe miasteczko.
Na stronie obok: Łuccy Euromajdanowcy nie zapominali przy tym... 


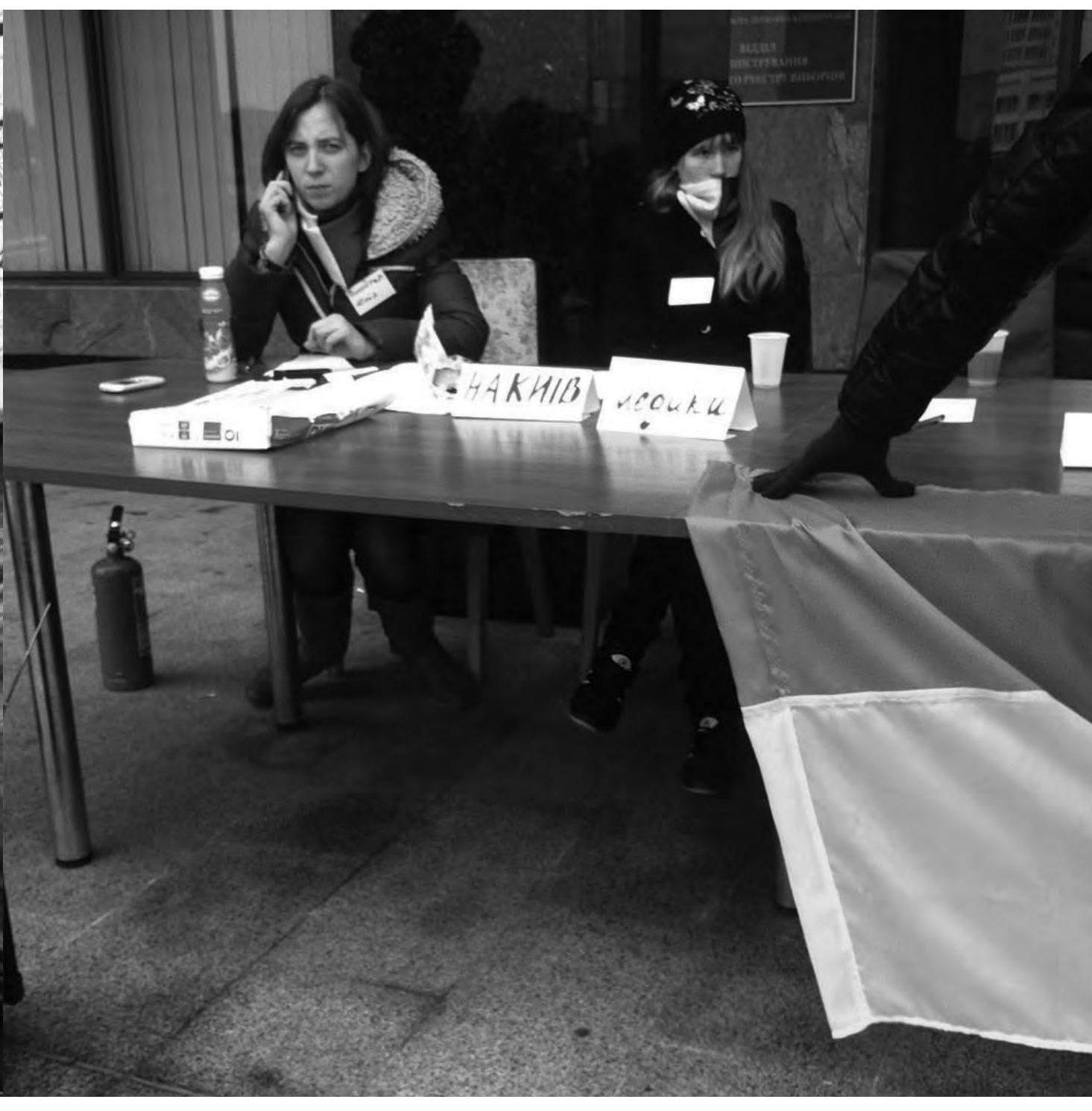




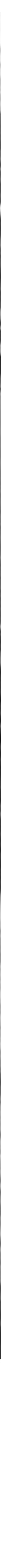




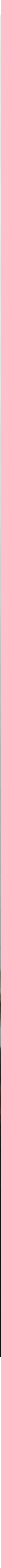




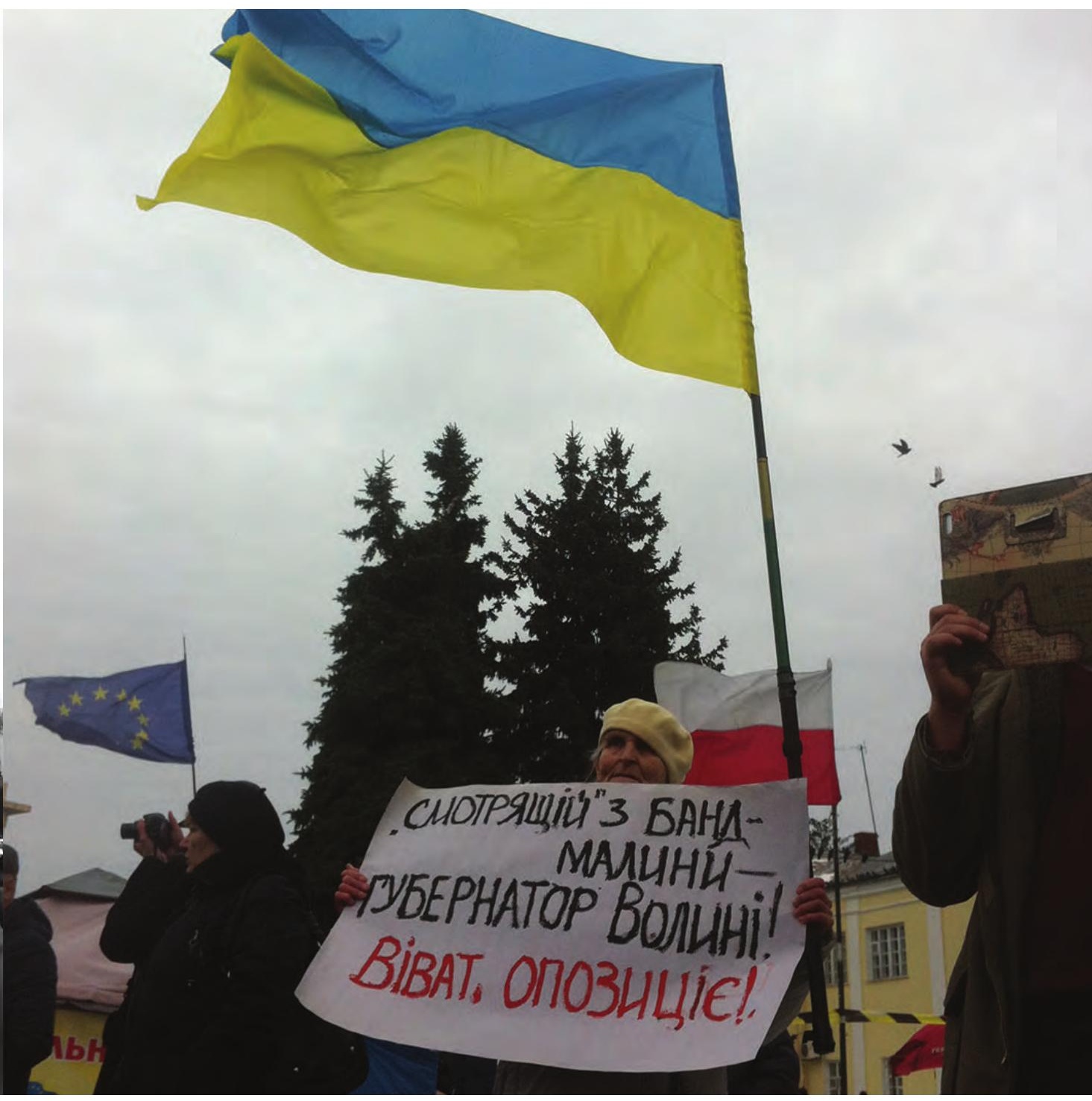




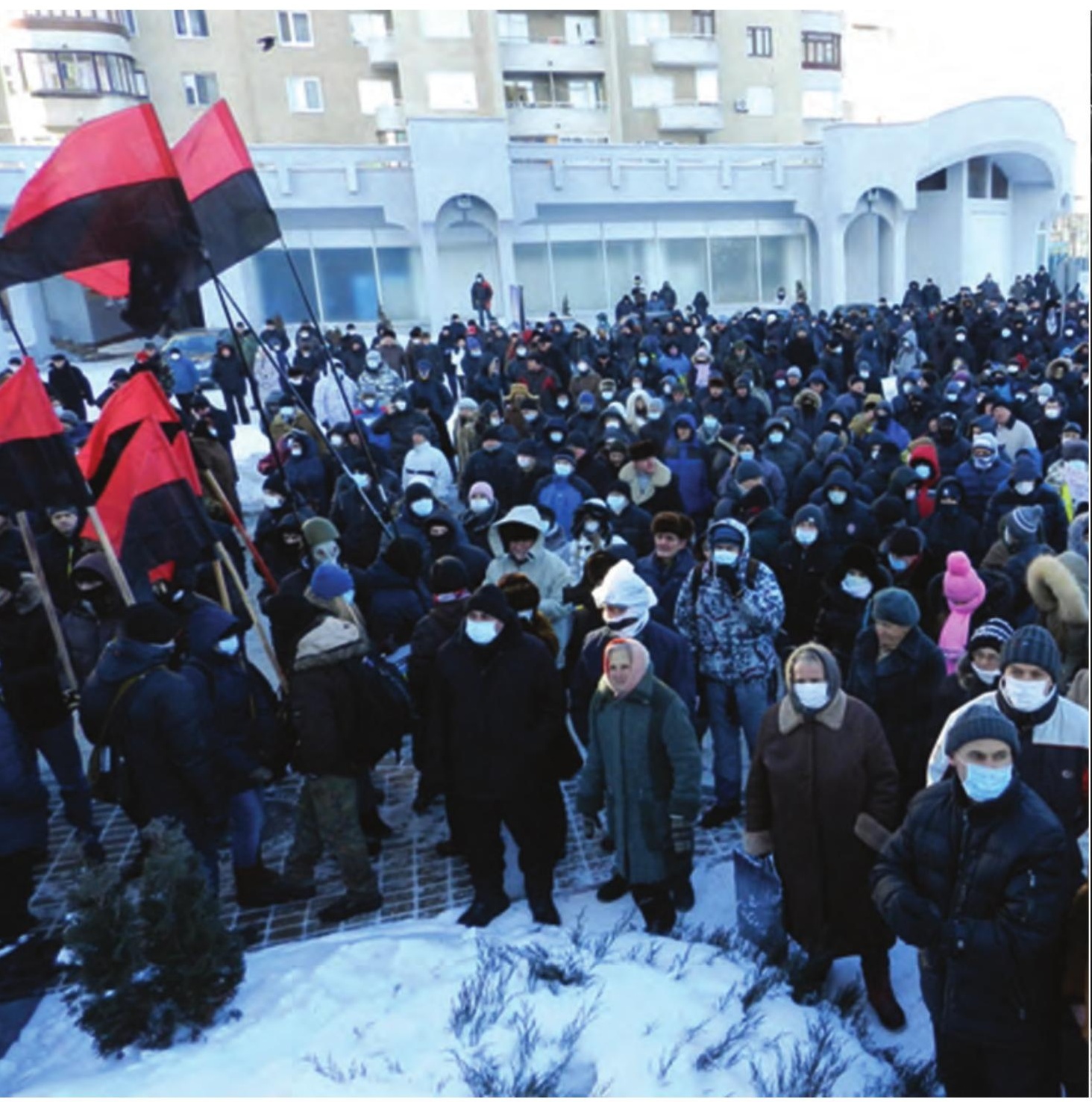

Wśród manifestantów wyróżniali się występujący pod swymi organizacyjnymi, historycznymi, czerwono-czarnymi sztandarami ukraińscy nacjonaliści.

Na stronie obok:

Swietłana Grela-Krawczenko (z lewej) i uczestnicy protestów w Łucku. 


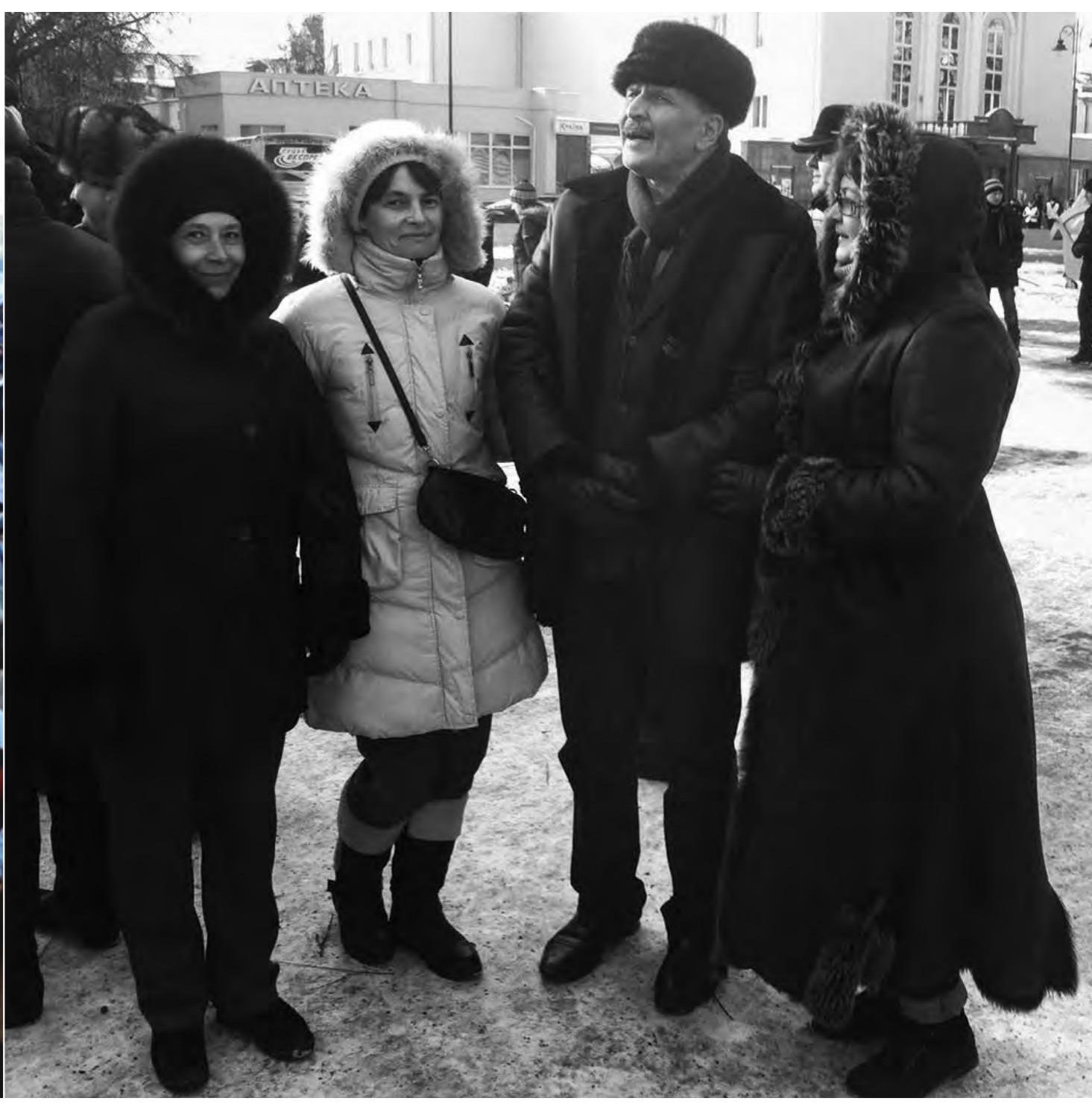




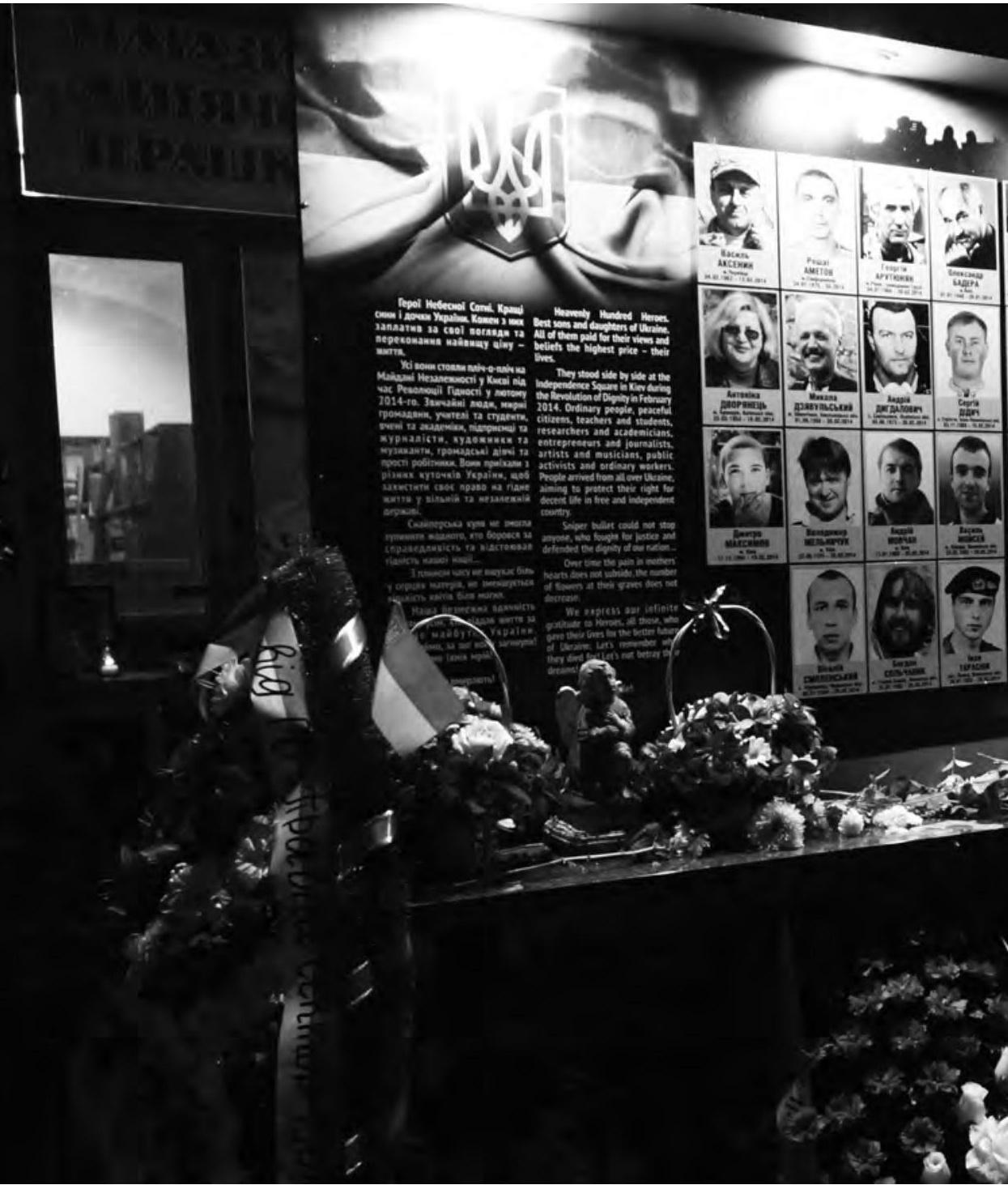

Pierwsza rocznica Euromajdanu w Łucku. „Aleja Pamięci” poświęcona ofiarom „Kijowskiego Powstania". 


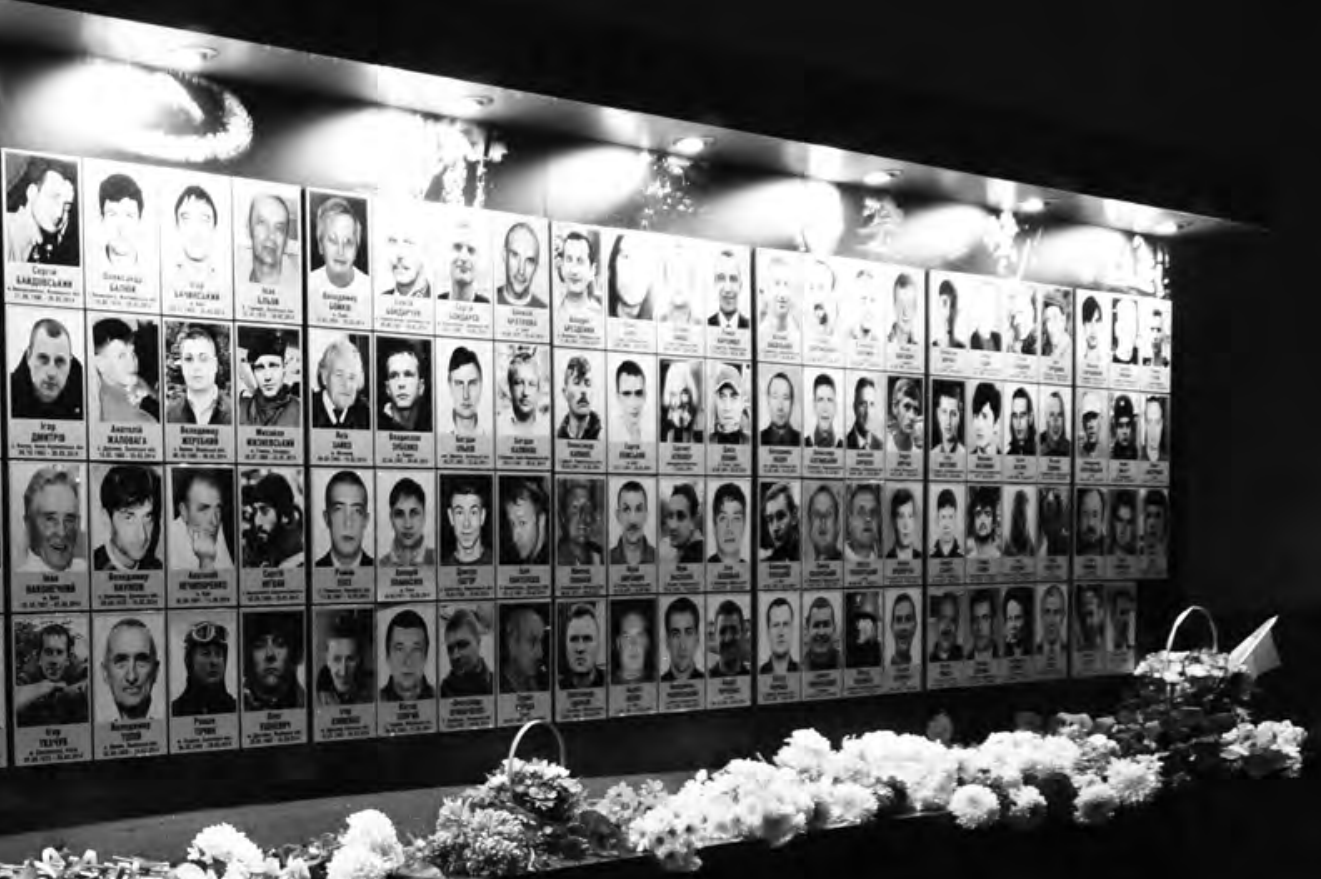

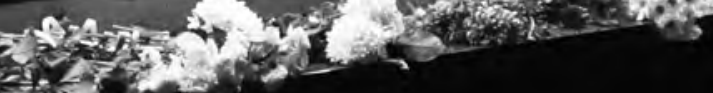
3.

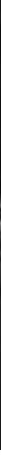



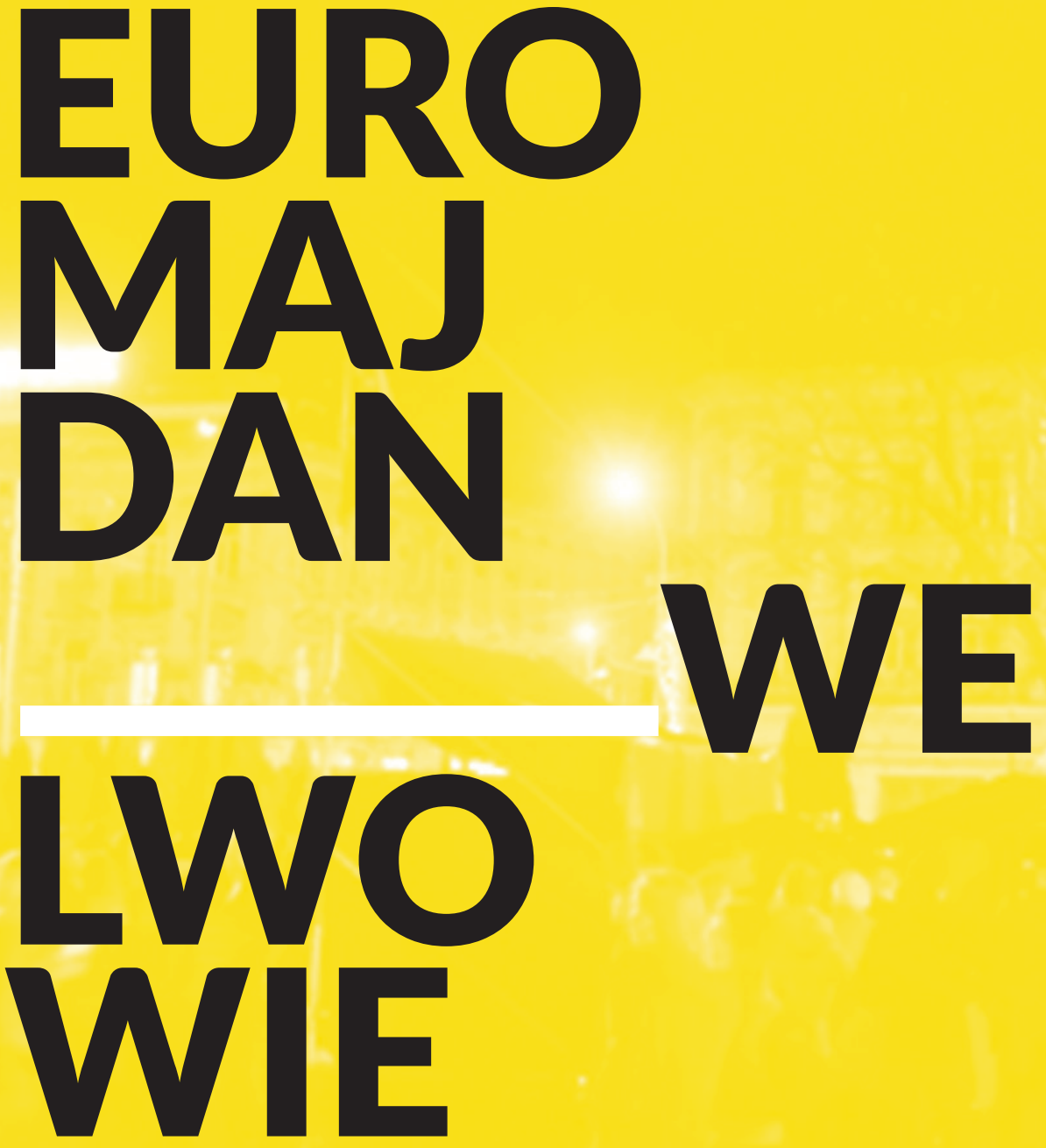


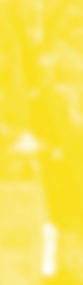

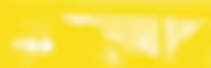




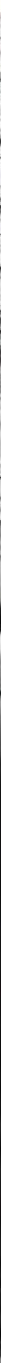

Pierwsze namioty protestujących przeciw reżimowi Janukowycza na Prospekcie Swobody we Lwowie (30 listopada 2013 r.).
Na stronie obok:

Tłum protestujących na Prospekcie Swobody gęstniał. Dołączali po- 


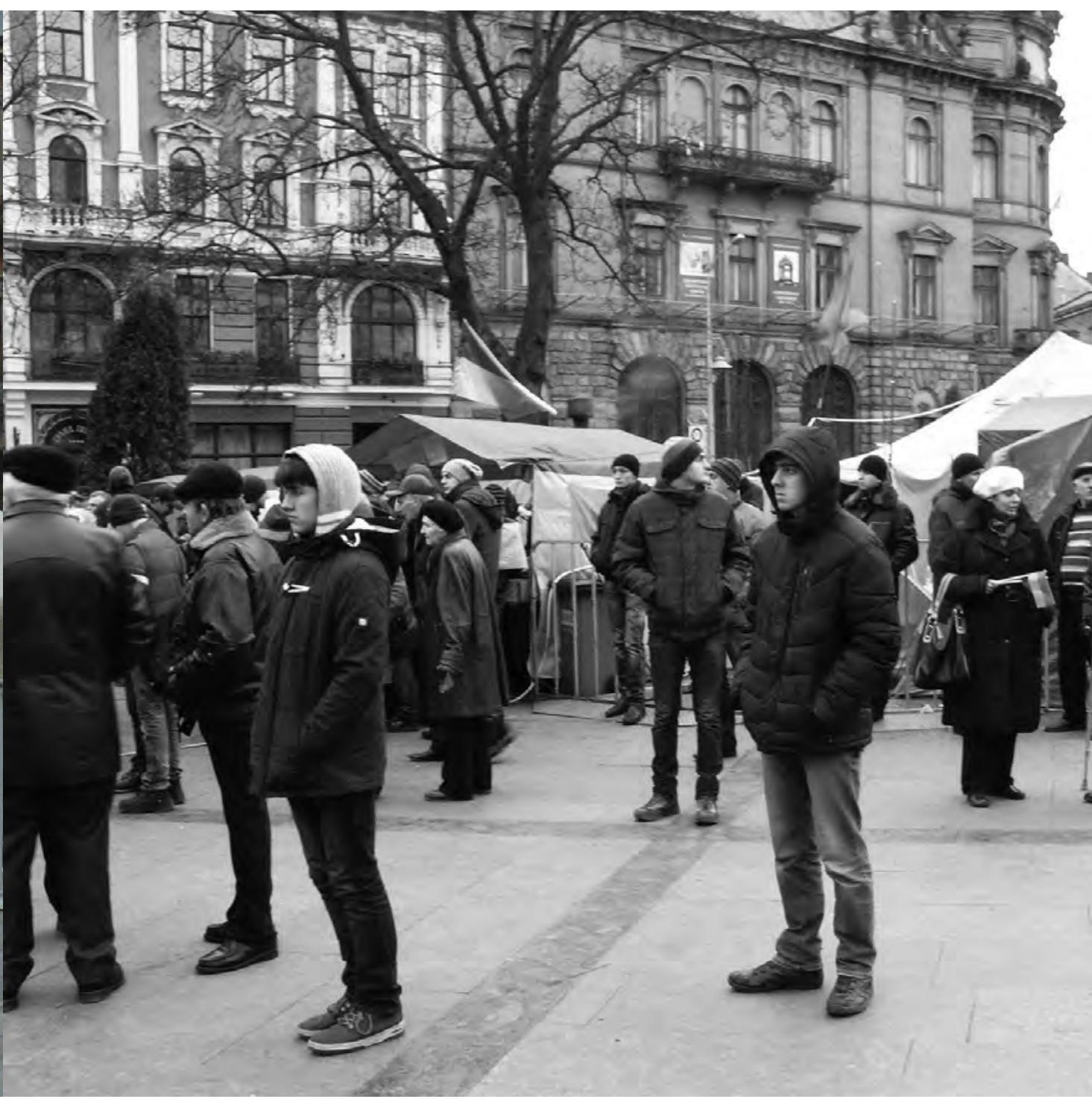

jedynczy demonstranci i zorganizowane grupy, reprezentujące różne środowiska polityczne. 


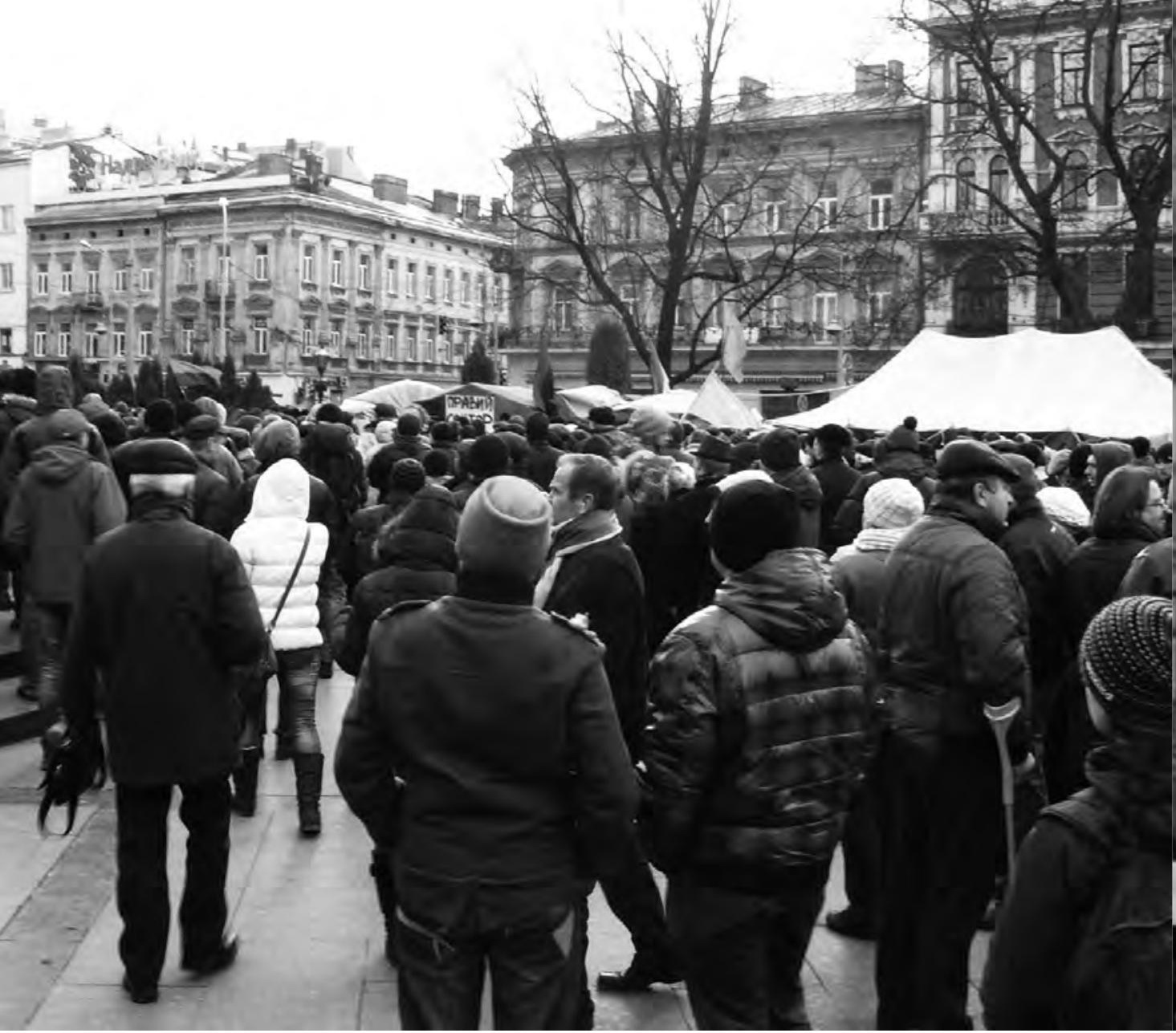

Zgromadzeni oglądają na telebimie wystapienie jednego z liderów ówczesnej opozycji, Arsenija Jaceniuka.
Na stronie obok:

Punktem zbornym

był pomnik wielkiego

ukraińskiego poety Tarasa Szewczenki... 


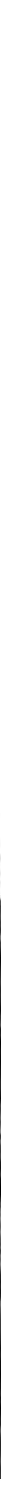




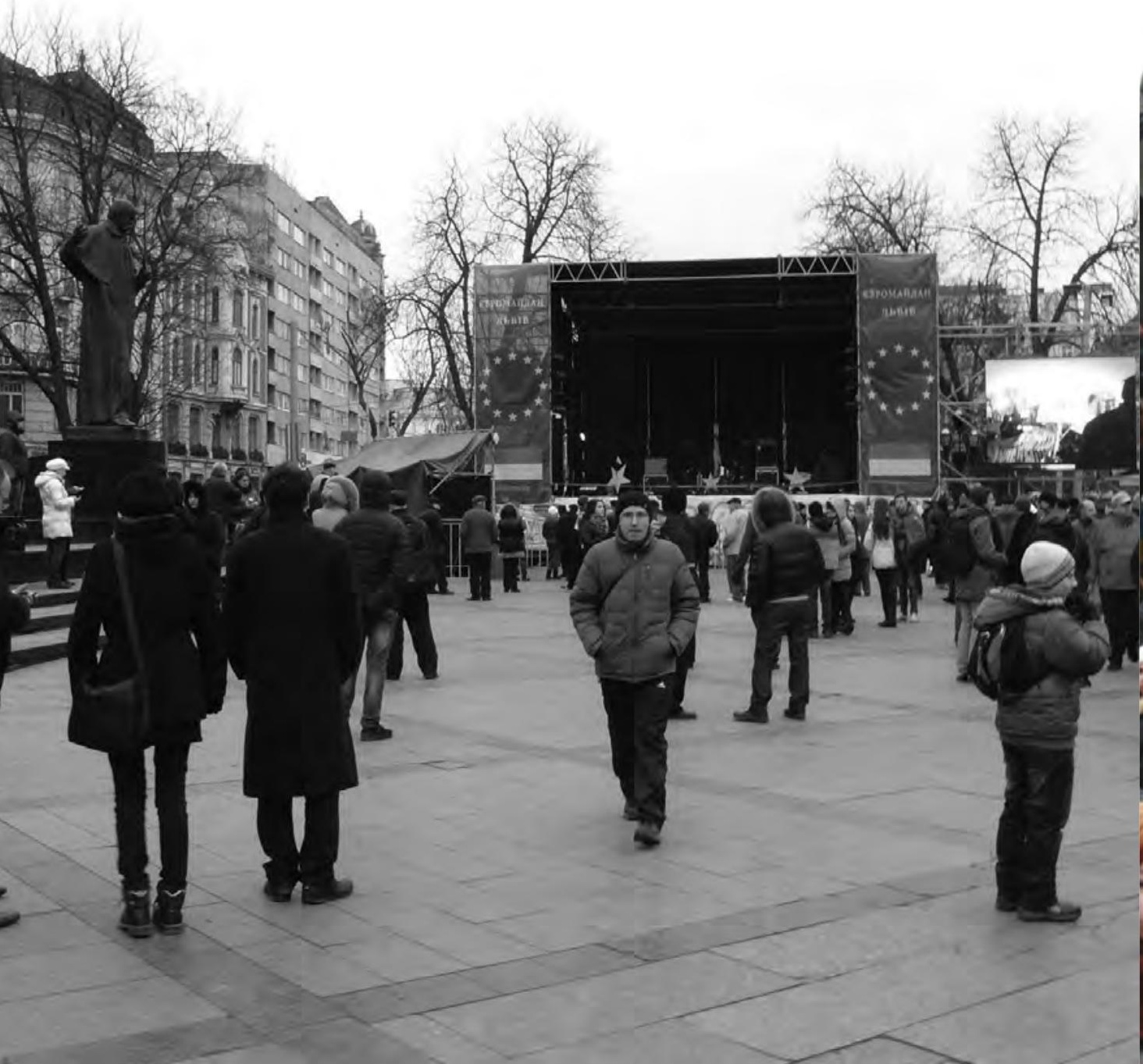

Scena w okolicach pomnika Tarasa

Szewczenki - stąd organizatorzy Iwowskiego protestu przekazywali manifestantom najnowsze informacje o sytuacji w Kijowie i na całej Ukrainie.
Na stronie obok:

Z czasem obok flag ukraińskich pojawiły się również flagi Unii Europejskiej. 


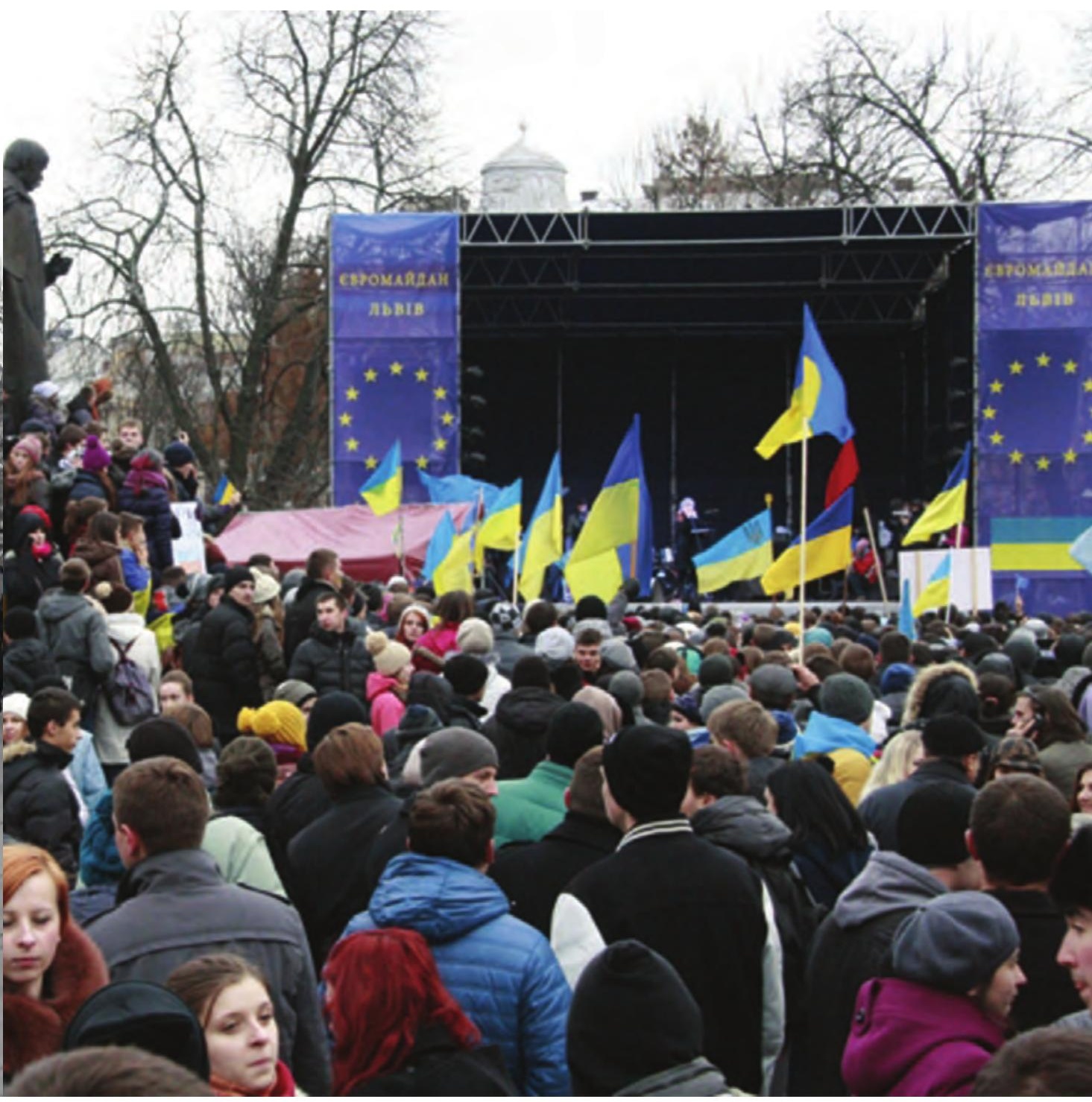




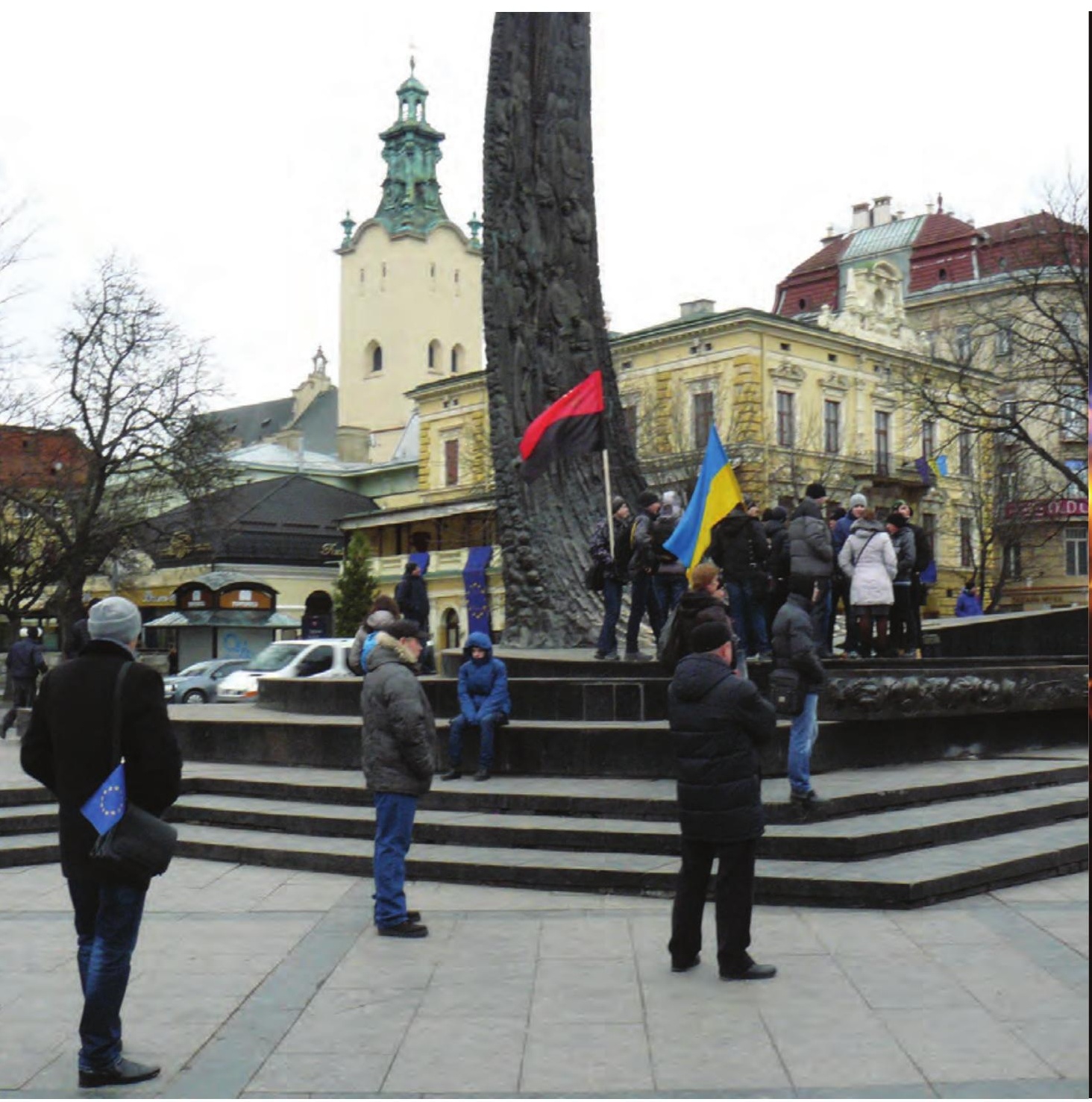

Obok barw ukraińskich nad tłumem widać także sztandary ruchu nacjonalistycznego.
Na stronie obok: Lwowski Euromajdan nocą. 


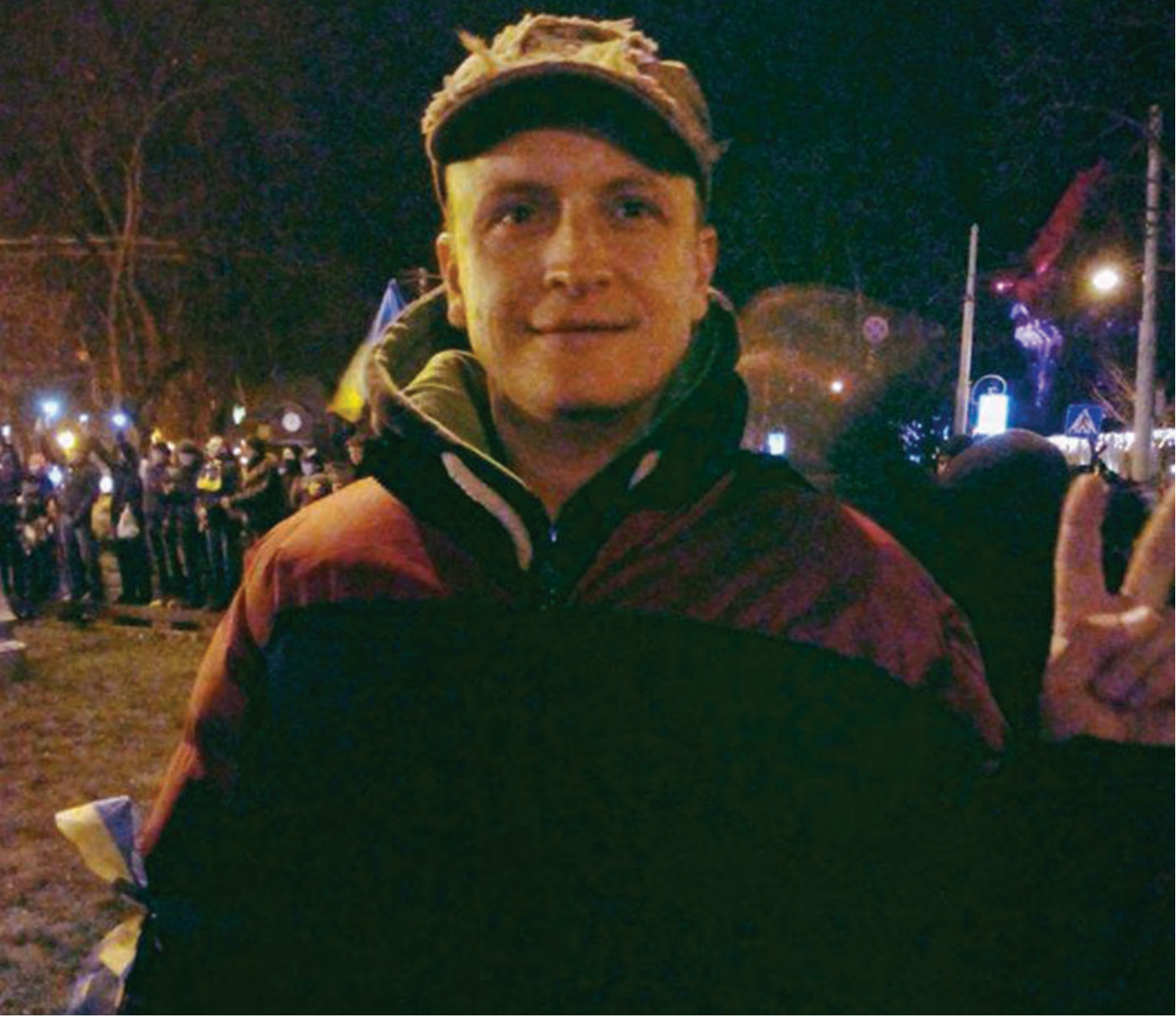

Współautor zdjęć z Majdanu na tle tłumu przeciwników Janukowycza, skandującego hasła mobilizujące zebranych do walki o wolną Ukrainę. 